BUDAPESTI CORVINUS EGYETEM

AZ ICT SZEKTORBAN MÜKÖDÖ PROJEKTVEZETŐK SZEMÉLYES JELLEMZÖINEK HATÁSA A PROJEKTSIKER ALAKULÁSÁRA

\author{
Doktori értekezés
}

Témavezető: Dr. Görög Mihály, CSc

Blaskovics Bálint

Budapest, 2014 


\title{
BLASKOVICS BÁLINT
}

\author{
AZ ICT SZEKTORBAN MÜKÖDÖ PROJEKTVEZETŐK \\ SZEMÉLYES JELLEMZÖINEK HATÁSA A PROJEKTSIKER \\ ALAKULÁSÁRA
}


Stratégia és Projektvezetés Tanszék

Témavezető: Dr. Görög Mihály, CSc

Copyright (C) Blaskovics Bálint, 2014 
Budapesti Corvinus Egyetem

Gazdálkodástani Doktori Iskola

\section{Az ICT szektorban müködő projektvezetők személyes jellemzőinek hatása a projektsiker alakulására}

doktori értekezés

BLASKOVICS BÁLINT

Budapest, 2014 


\section{Tartalom}

1. Bevezetés .........................................................................................11

2. A projekt értelmezésének közelítésmódjai .......................................16

2.1 A projekt értelmezésének fejlödésre …....................................... 18

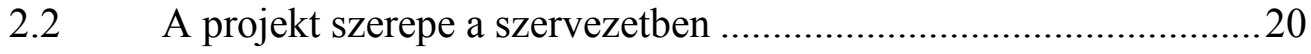

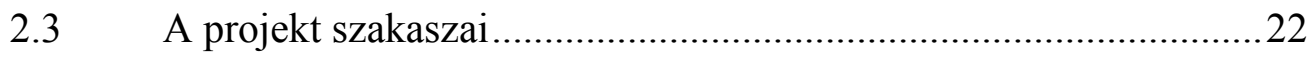

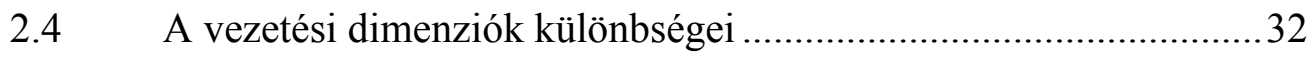

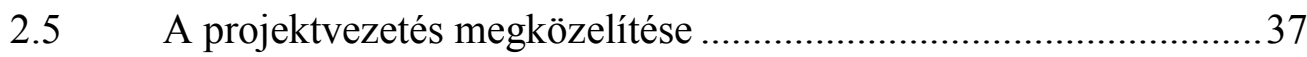

2.6 Az agilis projektvezetési módszertan rövid bemutatása..................40

2.7 A projektvezetés általános paradigmái...........................................41

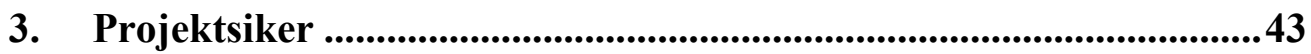

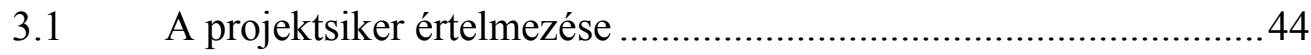

3.2 A projektsiker értelmezésének fejlődése ......................................45

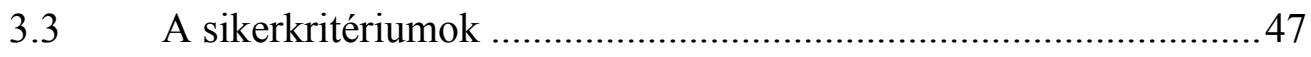

3.3.1 Az egyszintü megközelítések .............................................47

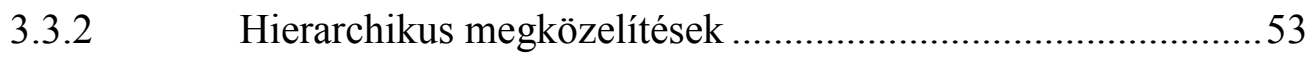

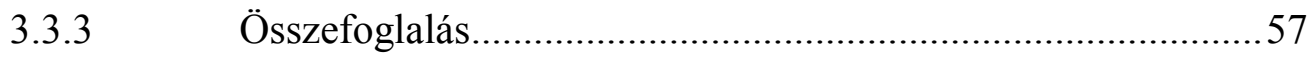

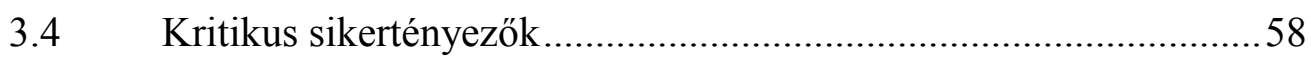

3.4.1 A kritikus sikertényezők fejlődése ......................................58

3.4.2 A kritikus sikertényezőket ért kritikák .................................61

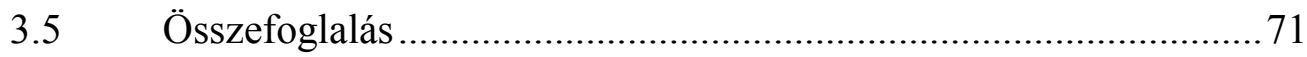

4. A projektvezetői kompetenciák .....................................................73

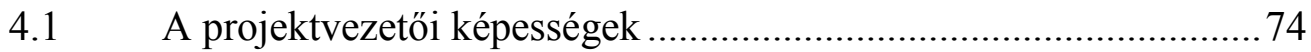

4.1.1 A projektvezetői képességek fejlődése .................................74

4.1.2 A projektvezetési eszközök csoportosítása .............................80

4.1.3 A projektmenedzser explicit és tacit tudása ...........................82

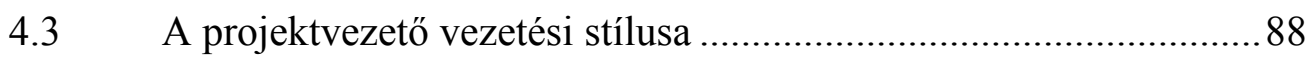


4.3.1 A vezetési stílusok szakirodalmának hiányosságai.................92

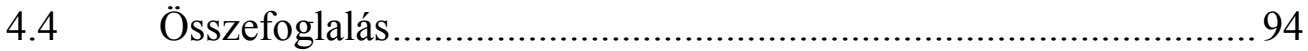

5. Empirikus kutatás: a projektvezető jellemzőinek hatása a projektvezetési szemléletmódra, vezetési stílusra és a sikerkritériumokra ........................96

5.1 A kutatás elméleti alapjai ..........................................................97

5.1.1 A kritikus sikertényezőket ért kritikák..................................97

5.1.2 A projektvezető projektvezetési szemléletmód hatásának vizsgálata, illetve ennek hiánya (összhangban a projekt és a projektvezetés értelmezésének fejlődésével) 98

5.1.3 A hasonló kutatások hiánya ……......................................... 99

5.2 Kutatási kérdések és hipotézisek ............................................. 99

5.2.1 A kutatás során használt módszertan ..................................... 101

5.3 A kutatás alapjául szolgáló minta ............................................. 107

5.3.1 Az iparág jellemzője ..................................................... 109

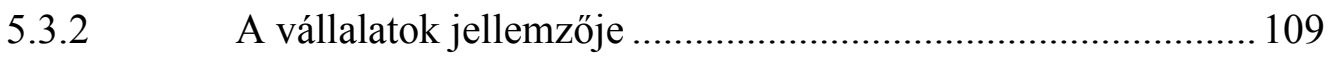

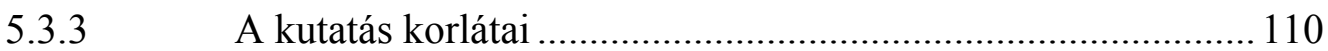

5.4 A kutatás eredményei ................................................................. 111

5.4.1 A projektvezető tudásának feltérképezés ................................ 111

5.4.2 A projektvezető által alkalmazott projektvezetési szemlélet azonosítása

5.4.3 Az azonosított projektvezetési szemléletmód projektsikerre gyakorolt hatásának kimutatása

5.4.4 A személyiségjegyek vezetési stílusra és projektvezetési szemléletmódra gyakorolt hatásának értékelése

$5.5 \quad$ Következtetések 187

5.6 A későbbi kutatások 191

5.7 Összefoglalás 191

6. Irodalomjegyzék 198 


\section{Táblázatok jegyzéke}

1. táblázat: A vezetési dimenziók összehasonlítása ...................................................33

2. táblázat: A projekttevékenység és az operatív müködés jellemzői ........................35

3. táblázat: A projekt értelmezésének, szakaszinak és a projektvezető feladatainak

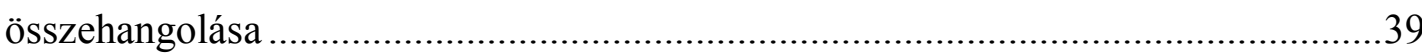

4. táblázat: A projekttípusok jellemzői a Project Excellence Model ${ }^{\circledR}$ szerint ..........66

5. táblázat: A projektvezetési eszközök hatása a sikerkritériumokra........................81

6. táblázat: A kompetenciák hatása a vezetési stílusra..........................................93

7. táblázat: A mintaelemszám megbontva vállalat szerint ................................... 108

8. táblázat: A projektvezetők ismert és alkalmazott eszközei/tevékenységek ........ 113

9. táblázat: A végső mintaelemszám megbontva vállalatok szerint....................... 116

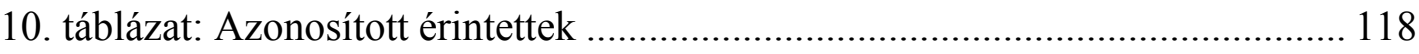

11. táblázat: A projektvezetési eszközök hatása a projektháromszög szerinti sikerességre

12. táblázat: A projektvezetési eszközök hatása a projekttulajdonosi

elégedettség szerinti sikerességre.

13. táblázat: A projektvezetési eszközök hatása az egyéb érintettek szerinti sikerességre 123

14. táblázat: A projektvezetők végzettsége 127

15. táblázat: A projektvezetők projektvezetési szemléletmódja 130

16. táblázat: A projektvezetési szemléletmód megoszlása vállalatok szerint 132

17. táblázat: A projektvezetői szemléletmód és a tudás kapcsolata 134

18. táblázat: A projektvezetési szemléletmód hatása a projektháromszög szerinti sikerességre 139 
19. táblázat: A projektvezetési szemléletmód hatása a projekttulajdonosi elégedettség szerinti sikerességre

20. táblázat: A projektvezetési szemléletmód hatása az érintettek elégedettsége

szerinti sikerességre

21. táblázat: A projektvezetési szemléletmód hatása a projektháromszög

projektsikerre 157

22. táblázat: A projektvezetési szemléletmódra hatást gyakoroló faktorok 161

23. táblázat: A személyiségjegyek változásának hatása 165

24. táblázat: A vezetési stílusra hatást gyakoroló faktorok. 168

25. táblázat: A személyiségjegy és vezetési stílus változása vagy állandósága 174 


\section{Ábrák jegyzéke}

1. ábra: A projektciklus általános modellje.............................................................23

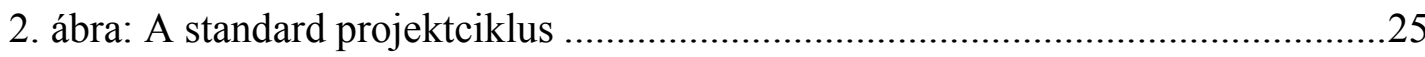

3. ábra: A projekt életciklusának egyéb megközelítése ...........................................29

4. ábra: Az agilis projektvezetési módszertan projektszakaszai ..............................31

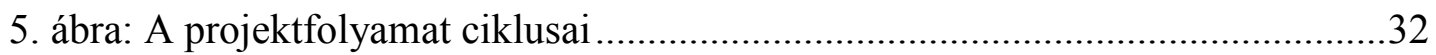

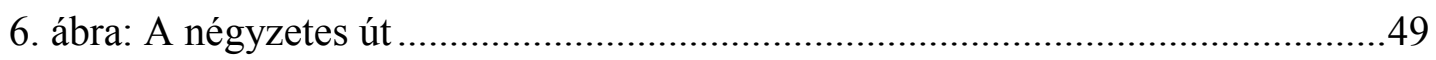

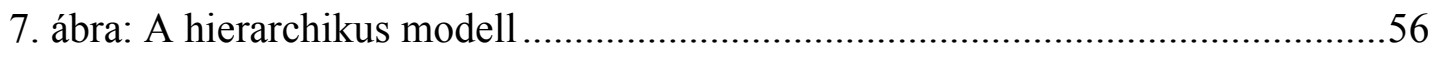

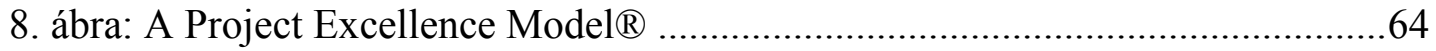

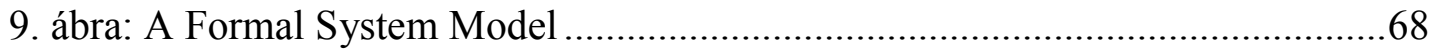

10. ábra: A projektvezetési specifikus kompetenciák szintjei .................................78

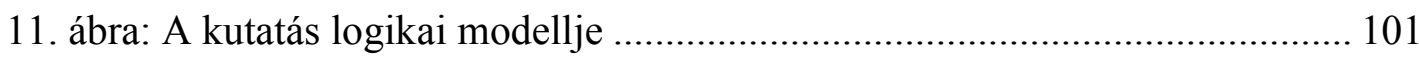




\section{Köszönetnyilvánítás}

Ezúton szeretnék köszönetet mondani témavezetőmnek, Dr. Görög Mihálynak, aki fáradhatatlanul segített $\mathrm{PhD}$ képzésem során, és hasznos tanácsokkal és lelkesítéssel járult hozzá, hogy megírjam az értekezésemet.

Köszönetet szeretnék mondani továbbá Dr. Szabó Lajosnak, aki opponensként sok hasznos tanáccsal látott el, segítve, hogy elnyerje az értekezés végső formáját. Szeretném megköszönni másik opponensemnek, Dr. Balaton Károlynak is a segítő szándékú megjegyzéseket, kiemelkedő észrevételek és a gondolatébresztő beszélgetéseket.

Hasonlóképpen szeretném megköszönni Dr. Kerekes Sándornak és Dr. Nemeslaki Andrásnak a PhD képzés során nyújtott szemléletformáló beszélgetéseket és tanácsokat.

Hálával tartozom továbbá tanszéki és intézeti kollégáimnak, különösképpen Dr. Mészáros Tamásnak, Dr. Fekete Istvánnak és Dr. Csubák Tibor Krisztiánnak, akik az értekezés megírásához rendkívül sok hasznos tanáccsal és segítséggel láttak el.

Köszönöm továbbá Dr. Prónay Gábornak, akinek észrevételei és a kutatási minta megszerzéséhez nyújtott segítsége révén elévülhetetlen érdemei voltak az értekezés megszületésében.

Nagyon köszönöm szüleinek, Závecz Máriának és Blaskovics Tibornak, valamint édesapám feleségének, Hörömpő Erzsébetnek a támogatást és türelmet, amit tanúsítottak a képzés során.

Valamint szeretném megköszönni barátaimnak, ismerőseimnek is, különösen Czakó Elődnek és Czakó-Jarábik Dórának, akik lelkesedésük és türelmük révén állandó inspirációt jelentettek. Kiemelném továbbá Szontágh Pétert, akinek ötletei, javító szándékú megjegyzései rendkívüli mértékben segítségemre volt a PhD képzés során.

Végül, de nem utolsó sorban szeretnék köszönetet mondani Horváth Viktóriának, aki kollégaként és barátként hasznos tanácsokkal és komoly segítséggel látott el a képzésem során. 


\section{Bevezetés}

A szervezetek mindig is törekedtek arra, hogy definiálják a sikert. Vállalati szinten ezt könnyen meg lehetett tenni. Hiszen rengeteg mutatószámot dolgoztak ki, legyen az direkt pénzügyi (kvantitatív), vagy egészen speciális, „puha” elemeket is felvonultató, kvalitatív módon megközelítő értékelés Ilyen példa előbbire a ROI vagy a ROA, míg utóbbi csoportba tartozik például a Kaplan - Norton Balance Score Card-ja, vagy a Sveiby Intangible Asset Monitor-a (ld. pl. Antal-Mokos et. al., 2003).

Azonban a projektek sikerét már jóval nehezebb volt megfogni. Ugyanis nem voltak ennyire kiforrott módszerek (komolyabban vizsgálni a projektsikert az 1960as években kezdték). Pedig az egyik legnagyobb értéket teremtő folyamat a vállalaton belül a projekt.

A projektek sikeressége, és ebből fakadóan ennek biztosítása manapság kulcskérdéssé vált minden szervezet számára. Köszönhető ez annak a ténynek, hogy az új szituációkhoz, a megváltozott környezeti feltételekhez valamint a stratégák által megálmodott új irányvonalhoz való alkalmazkodás/kivitelezés eszköze a projekt (Görög, 2003). Így amennyiben egy szervezet nem indít megfelelő mennyiségü projektet, óhatatlanul statikussá válhat. Márpedig egy statikus vállalat a mai, rendkívüli mértékben felgyorsult világban csak nagy szerencsével maradhat életben. Természetesen ez nem csak mikroszinten, azaz a szervezetek szintjén értelmezhető, hanem országok, sőt államközösségek (pl. EU) szintjén is ${ }^{1}$.

Ezt felismerve a válságig a projektekre költött összeg igen jelentős volt és folyamatosan nőtt (Bredillet, 2007; Standish Group, 2009; World Bank, 2005), a múlt évtized közepére megközelítette a világ GDP-jének 20\%-át ${ }^{2}$. Azonban a projektek életre hívása még nem feltétlenül elégséges ahhoz, hogy egy vállalat, ország vagy régió sikerrel alkalmazkodjon a megváltozott körülményekhez, szükséges, hogy a projekt eredményesen (hatásosan és lehetőleg hatékonyan) végződjön. Sajnos azonban a gazdag szakirodalom ellenére manapság igen nagy a

\footnotetext{
${ }^{1}$ Ilyenkor azonban természetesen eltérő környezetben, eltérő kritériumrendszerben történik a projektek életre hívása és vezetése, hiszen a non-profit szektor más értékeket helyez középpontba, mint a for profit szektor.

${ }^{2}$ Valószínűsíthetően a projektekre szánt összeg a válság után is jelentős lehet, bár erről kimutatások nem állnak rendelkezésre.
} 
különbség az életre hívott projektek és a sikerrel végződött projektek száma között. Az arány megközelítőleg 35\% körül van (Standish Group, 2009), azonban az információs rendszerekhez kapcsolódó esetében ez a szám még alacsonyabb, mindössze 30\% körül mozog (Deák, 2001). Ráadásul az ilyen projektek 15-20\%-át még a befejezés előtt leállítják, azaz már a megvalósítási vagy a tervezési fázisban olyan helyrehozhatatlan hiba keletkezik, aminek következtében jobban megéri a visszavonás mellett dönteni (Kappelman et. al. 2006; Lee-Kelley - Loong, 2003) ${ }^{3}$.

Többen rámutattak arra, hogy az okok között kevésbé markáns szerepet játszanak a technikai vagy erőforrásbeli hiányosságok, mint ahogy azt gondolnánk. Ugyanis a piacon nagyjából elérhetőek a szükséges technikai és humán erőforrások, azaz ha hiány keletkezik, akkor megfelelő ellenérték fejében viszonylag könnyen be lehet szerezni. Valamint a vállalatok felismerték, fel kellett, hogy ismerjék a projektek szükségességét, ezért megfelelő mennyiségű belső erőforrással is ellátják a projektjeiket (pénz, projekttag, infrastruktúra), amennyiben megfelelően magas prioritású projektről beszélünk. Tehát a fő ok nem az erőforrásbeli hiányosságokban keresendö $^{4}$, hanem sokkal inkább az elégtelen behatárolás, azaz a projekttulajdonos és az egyéb kulcsszerepet játszó érintettek igényeinek mellőzése, a külső és belső változásokra történő megfelelő mértékű és idejű reagálás hiánya vagy a projektmenedzser felkészültségének hiánya (1sd. pl. Judgev - Müller, 2005; Jing et al., 1996; Yeo, 2002).

Ezek alapján a projektsiker és az azokat elősegítő tényezők vizsgálata kiemelten fontos lehet mind az akadémiai szféra, mind pedig a gyakorló szakemberek számára. Így értekezésem alapvezető célkitüzése a projektsiker elősegítésének jobb megértése. Ebből fakadóan szükséges lehet megvizsgálni, hogy milyen tényezők hatnak a projektsikerre, és azt, hogy ezek miként hatnak egymásra. Mivel ez a célkitűzés túl komplex és túl tág ahhoz, hogy átfogó, minden egyes faktorra kiterjedő vizsgálatot végezzek, értekezésem középpontjában a projektmenedzseri felkészültség, pontosabban a projektmenedzser projektvezetési

\footnotetext{
${ }^{3}$ Ez nem feltétlen a projektmenedzser hibája. Ez lehet a külső változások miatt is, hiszen az IT környezet a szokásosnál is dinamikusabban és gyorsabban változik (vö. Mészáros, 2010). Ezekre pedig a reagálás nem mindig egyszerü, még a gazdag változásmenedzsment eszköztár ellenére sem.

${ }^{4}$ De természetesen, ha ezek nem állnak rendelkezésre, akkor a projekt ugyanúgy kudarccal végződik.
} 
szemléletmódja áll, méghozzá a projektsiker és két másik projektvezetői jellemző (személyiségjegyek, vezetési stílus) tükrében. Azaz arra adok választ értekezésem során, hogy bír-e hatással a projektvezető projektvezetési szemléletmódja a projektsikerre, míg a projektvezető személyiségjegyei hatással vannak-e a projektvezetési szemléletmódra és vezetési stílusára.

A kutatás során az alkalmazott módszertan mélyinterjú volt. A minta alapját pedig az ICT szektorban tevékenykedő multinacionális vállalatok leányvállalatinak projektvezetői jelentették. 5 hazai vállalat 31 projektvezetőjével készítettem interjút, és válaszaik alapján a kutatási kérdések megválaszolása lehetővé vált.

Az értekezés során kitérek arra, hogy a kutatás eredményeit szervezetek milyen módon tudják használni a gyakorlatban során. Szeretnék rávilágítani arra, hogy milyen irányba célszerü hangolni az akadémiai kurzusokat és vállalati tréningeket. Szeretnék továbbá abban is támpontot adni, hogy a kutatás alapjául szolgáló szektorban, és az ahhoz hasonló ágazatokban milyen vezetési stílust célszerü alkalmazni ahhoz, hogy a projektsiker esélyét növeljék. Ebböl fakadóan a disszertáció kiváló alapot képezhet olyan vállalati tréningek és akadémiai kurzusok kidolgozásához, amelynek célja a projektvezető projekttudásának fejlesztése.

Az értekezésnek viszont nem célja, hogy olyan keretrendszert hozzon létre, amellyel a vállalatok értékelhetik a projektvezetők tudását, illetve az sem célja, hogy ezek a kurzusok a disszertáció keretében kidolgozásra kerüljenek. Nem célja továbbá azt sem, hogy a hatások mértékét kimutassa, és az sem, hogy feltérképezze az összes releváns tényezőt, amely a projektvezetési szemléletmódra és a vezetési stílusra hatással van, mint ahogy az sem, hogy megtalálja a legnagyobb hatást gyakorló tényezőt. Ez természetesen nem azt jelenti, hogy a disszertációhoz kapcsolódó kutatás eredményeit ne lehetne felhasználni egy későbbi kutatás vagy keretrendszer kidolgozása során, amelynek célja a korábban említettek egyike.

Ennek megfelelően a disszertáció 4 fejezetből épül fel a bevezetésen kívül, amelyek a következők:

- Disszertációm második fejezetében röviden bemutatom a projekt fogalmának fejlődését, alapvető jellemzőit és ciklusait. Ennek fontosságát az indokolja, hogy ez alapján látni lehet, a projektek menedzselése eltérő tudást, eltérő ismeretet igényel, 
mint a hagyományos értelemben vett vezetés, azaz egy vállalat vagy szervezet (legyen az $\mathrm{KKV}$, non-profit vagy pedig nagyvállalat). Ezek után bemutatom a különböző vezetési dimenziókat, kitérek, milyen szempontból különbözik a szervezetek és a projektek menedzsmentje. Bemutatásra kerülnek továbbá a projektvezető feladatai, és (a gyakorlati rész szükségessége miatt) röviden jellemzésre kerül az agilis projektvezetési módszertan. Ebben a fejezetben kerülnek bemutatásra továbbá a projektmenedzsment általános paradigmái is.

- Az értekezés harmadik fejezetének fókuszában a projektsiker értelmezése, annak fejlődése valamint azok összetevői állnak. Bemutatom a sikerkritériumokat, amik a projektet értékelik sikeresség szempontjából. Valamint szintén ismertetésre kerülnek a kritikus sikertényezők (KST-k) is, amelyek a projektsiker elérését segítik elő. A fejezet utolsó részében pedig bemutatom a sikertényezőket ért kritikákat, a sikertényezők és sikerkritériumok összehangolásukra tett kísérleteket. Illetve röviden bemutatom ezek hiányosságait is.

- Az értekezés negyedik fejezete taglalja a projektvezető tudását, személyiségjegyeit és vezetési stílusát. Bemutatásra kerül a projektmenedzseri tudás értelmezésének fejlődése, komplexitása, valamint az, hogy milyen tudásbeli és egyéb feltételeknek kell ma megfelelnie annak a személynek, aki projektek vezetése mellett dönt. Röviden kitérek a kvalitatív és kvantitatív eszközökre és a tacit és explicit tudásra is. Azonosításra kerülnek továbbá a projektvezető személyiségjegyei (optimizmus, érzelmi intelligencia, csapatépítő képesség, bizalomépítő képesség, motiváló képesség és optimizmus). Emellett a vezetési stílusok is jellemzésre kerülnek, külön kitérve arra, hogy ennek a hat személyiségjegynek (és egyáltalán a tisztán személyiségjegyek) hatásának vizsgálata hiányos.

- Az értékelés ötödik fejezete foglalja magában a kutatás leírását. Bemutatásra kerül az, hogy milyen elméleti alapra támaszkodik. Ezek alapján megfogalmazom a kutatási kérdéseket és az ebből következő hipotéziseket. Továbbá bemutatásra kerül a kutatásom logikai modellje is. Leírásra kerül továbbá az alkalmazott kutatásmódszertan és az interjúkérdések is. Definiálásra kerül emellett a kutatás környezete, az iparág, a mintavételi eljárás és az elvárt mintavételi mennyiség is. Kiértékelésre és elemzésre kerülnek az interjú során adott válaszok, részletes, kérdések szerinti megbontásban. Végül az interjúk alapján a hipotézisek elfogadása vagy elvetése és (ennek alapján) tézisek felállítása történt meg. A fejezet végén a 
kutatás alapján levont főbb konklúziókat ismertetem, valamint azt, hogy ennek milyen relevanciája lehet az akadémiai szektorra és a magánszférára nézve.

A dolgozatom főbb eredményei a következők:

- A kvantitatív projektvezetési eszközök nem járulnak hozzá nagyobb mértékben a projektsiker három szintjéhez, mint a kvalitatív eszközök. Ebből fakadóan a kvalitatív eszközök legalább olyan fontossággal bírnak a projektsiker biztosítása során, mint a kvantitatívak.

- A projektvezető projektvezetési szemléletmódján az explicit tudás nincs nagyobb mértékben jelen, mint a tacit. Így megállapítható, hogy a tacit tudás átadására is nagy hangsúlyt kell fektetni.

- A projektvezető projektvezetési szemléletmódja befolyással bír a projektsiker mindhárom szintjére. Azaz a megfelelő projektvezetői szemléletmód fejlesztése, kialakulásának elősegítése fontos lehet, amennyiben a vállalatok növelni akarják a projektsiker elérésének esélyét.

- A projektvezető személyiségjegyei befolyással bírnak a projektvezető projektvezetési szemléletmódjára és a vezetési stílusára. Ennek alapján megállapítható, hogy a személyiségjegyek fejlesztésére is komoly hangsúlyt kell fektetni, hiszen indirekten hatással van a projektsikerre (a projektvezetési szemléletmód és a vezetési stílus által).

Mindezek támpontot nyújthatnak az egyetemi kurzusok és vállalati tréningek tartalmának finomításához, méghozzá olyan mértékben, hogy a tacit tudásátadás és a kvalitatív elemek megfelelő ismertetése is megtörténjék. Továbbá célszerü a projektvezető szemléletmódjára (és így a projektsikerre) hatást gyakorló projektvezetési szemléletmódot fejleszteni. Ez pedig főként szituációs játékok, esettanulmányok és mentoring rendszer keretében valósulhat meg (vö. Horváth, 2013). 


\section{A projekt értelmezésének közelítésmódjai}

A projekt értelmezése sokat módosult az idők folyamán, alkalmazkodva azokhoz az elvárásokhoz, amelyeket manapság ez a turbulens gazdasági környezet támaszt. A legelső projektmegközelítések még a taylori érába nyúlnak vissza, amely egészen az 1970-es évekig tartotta magát (1sd. pl. Gaddis, 1959; Olsen, 1971). Ezek szerint a definíciók szerint a projekt nem más, mint olyan tevékenység vagy tevékenységek sorozata, amelyet világosan behatárol a ráfordított idő, költség és az elvárt minőségi paraméterek ${ }^{5}$.

Az idő előrehaladtával ${ }^{6}$ ezek a megközelítések érvényüket veszítették, hiszen számtalan olyan projektet hívtak életre, amelyekben az idő, költség, minőség (azaz a projektháromszög) fontos szerepet töltött be, azonban a projekt maga - csakúgy, mint az új kor - túllépett ezen. A PMBOK® a következőképp definiálja:

•,„A projekt időben behatárolt erőfeszítés egy egyedi termék, szolgáltatás vagy eredmény létrehozása céljából.” (Project Management Institute, 2006, 21. oldal)

A definícióból világosan látható, hogy a projektértelmezés már túllép az önmagában elégtelenné vált, de a projekt jellegéből fakadóan elengedhetetlenül fontos projektháromszögön, és bevezeti az eredményorientáltságot. Ugyanis fontos lehet az adott időben, adott költségen, adott minőségben történő teljesítés, de nem ez válik a projektek lényegévé (vö. Judgev-Müller, 2005). Méghozzá ez köszönhető annak a ténynek, hogy a környezet elvesztette statikus voltát (Mészáros, 2010). Így önmagában az, ha egy projektszerü beruházás ${ }^{7}$ adott költségen, adott minőségen és adott időre teljesül, még nem garantálja a megfelelő eredmény létrejöttét. Ezért váltak szükségessé az eredményorientált definíciók. Természetesen ez nem azt jelenti, hogy a projektháromszög (idő, költség, minőség) paraméterei elhanyagolhatóak lennének, csupán azt, hogy ezek önmagában már nem felelnek meg a mai projektértelmezésnek.

\footnotetext{
${ }^{5}$ A minőségi paraméterek köthetőek tevékenységekhez is, de jelen esetben a létrehozandó projekteredmény elvárt jellemzőit foglalja magába.

6 Továbbá annak a ténynek is köszönhetően, hogy a klasszikusnak számító, föként infrastrukturális projektek mellett megjelentek a kevésbé jól vagy rosszul kvantifikálható projektek, mint például a $\mathrm{K}+\mathrm{F}$ vagy ürkutatási projektek.

${ }^{7}$ A beruházás nem feltétlen egyenlő a projekttel. Ugyanis be lehet ruházni projekt nélkül is (pl. munkaerő felvétele).
} 
Ebből fakadóan Görög a következőképpen definiálja a projektet:

•,,.. projekt minden olyan tevékenység, amely egy szervezet számára olyan egyszeri és komplex feladatot jelent, amelynek teljesítési időtartama (kezdés és befejezés), valamint teljesítésének költségei meghatározottak, és (hasonlóan a stratégiai célfeladatokhoz) egy adott eredmény (cél) elérésére irányul...” (Görög, 2003, 20. oldal)

Jellegében hasonló definíciót ad Clements és Gido is, úgymint:

-,A projekt olyan törekvés, amelynek célja egy jól definiált eredmény megvalósítása egyedi tevékenységek halmazán keresztül az erőforrások hatékony felhasználása által.” (Clements - Gido, 2006, 4. oldal)

Látható ebböl a két definícióból is, hogy a projektháromszög és az eredményorientáltság egyidejüleg jelenik meg. Összecsengve az előző, Project Management Institute által adott meghatározással, ez a definíció is kizárja az ismétlődést. Azaz egy projekt mindig egyedi, mindig szükséges, hogy valami újat hozzon létre. Ez a tény a projekt szerepéből fakad, méghozzá abból, hogy a környezet változására adja a választ. Ez pedig óhatatlanul kizárja azt, hogy olyat hozzon létre, ami már létezik a vállalatban.

Eric Verzuh (2008) még szervezetcentrikusabban közelíti meg a projekteket, hiszen nem csak a projektháromszöget és az eredményorientáltságot emeli ki, hanem a teljesítés alapjául szolgáló szervezet (a projektszervezet) is. Ez alapján meg lehet állapítani, hogy számára a projekt nem csak egy tevékenység, tevékenységsorozat vagy folyamat, hanem olyan szervezet/szerveződés, amely adott eredmény elérésére jött létre adott korlátok mellett.

Összességében megállapítható tehát, hogy a projekt értelmezése sokat változott az idők folyamán, és a mai értelmezések már az alábbi jellemzőkkel bírnak:

• szervezet vagy szerveződés,

• eredmény elérésére irányul,

- ideiglenes, egyedi,

• időben, költségben korlátos. 
Azaz a bizonytalanságnak köszönhetően, amely egyre nagyobb mértékben immanens tulajdonságává vált a projektnek (vö. Judgev-Müller, 2005), a projektek definíciójának fókusza is megváltozott. A kezdeti projektháromszögről átterelődött a hangsúly az eredményközpontúságra és az utóbbi időben a szervezetközpontú megközelítések is teret nyertek. Természetesen ez hatással van a projekt menedzseléséhez szükséges képességekre is (pl. a vezetéshez kapcsolódó ismeretek szükségessége felértékelődik).

Ezek alapján talán Fekete és Dobreff (2003, 9. oldal) adja a legteljesebb definíciót, amely a következőképpen hangzik:

„,...projektnek tekintjük azokat a feladatokat, amelyek:

• konkrétan körülhatárolt, nagy jelentőségü (stratégiai) cél elérését szolgálják,

• összetett szakértelem igénye miatt több szervezet bevonását igényli,

•nem sorolhatóak a hagyományos felelősség elhatárolás szerint müködő szervezeti egységek szokásos tevékenységei közé,

- pontosan rögzített határidőre kell befejeződniük,

•jól meghatározott költségkeretek között müködnek,

-a müködési környezetben viszonylagosan újat, ezért végrehajtásuk kockázatot rejt magában,

• dinamikus végrehajtást igényelnek (a feltételek menetközben változhatnak).”

Ebben a definícióban egyszerre jelenik meg a projektháromszög szerinti szemlélet, a szervezeti szemlélet, az egyediség és az eredményorientáltság. Így megállapítható, hogy ez a projektdefiníció teljes.

\subsection{A projekt értelmezésének fejlődésre}

A projekt értelmezése (ahogy az 2. fejezetben is megállapításra került), alapvető fejlődésen esett keresztül. A projektháromszögre fókuszáló megközelítéseket felváltotta a komplexebb megközelítések. A projektértelmezések egy része a projekt egyedi feladat voltát helyezte a középpontba, és így közelíti meg. Azaz meghatározott kezdő-, illetve végponttal rendelkezik adott költségkerettel, és a projekt eredményei is meghatározott. Természetesen ilyenkor a hangsúly a kvantitatívabb elemen van, azaz a folyamat-, és az eredménykontroll, valamint az 
ehhez kapcsolódó tényezők kerülnek előtérbe (költségtervezés, időtervezés stb.) (vö. pl. Goldratt, 1997;). Ennek a nézetnek az életképességét a klasszikus projektmenedzsment megközelítések adják (ld. pl. Project Management Institute, 2006), hiszen ezek szerint a projektmenedzsment igen lényeges eleme a projektterv elkészítése és betartása (és természetesen ezek vizsgálata).

Azonban Lundin és Söderlund (1995) rámutatott arra, hogy a projektek nem csak egyedi feladatok, hanem ideiglenes szervezetek is. Ebböl fakadóan a projektet lehet és szükségszerü is szervezetcentrikusabban is vizsgálni, azaz a projektek egy olyan, erre a célra felállított szervezet keretében kerülnek kivitelezésre, amelynek középpontjában az emberek (föként a projektcsapat) áll. Ennek a nézetnek az életképességét az adhatja, hogy a projektszervezet mintegy ráépül a vállalati hierarchikus struktúrára és a projekt ennek keretében kerül kivitelezésre ${ }^{8}$. Megállapítható továbbá hogy ideiglenes szervezet révén a projektszervezet megszüntetése a projekt befejeztével megtörténik. Így óhatatlanul rövidebb ideig létezik, mint a projekt alapjául szolgáló szervezet (vö. Rozman, 2006), kivéve ha a szervezet szerepe egyedül az adott projekt teljesítése.

Ezzel párhuzamosan Cleland (1994) rámutatott arra, hogy a projekt tekinthető stratégiai építőelemként is, hiszen a stratégiai eszközök megvalósítását jelentik a projektek. Azonban ilyenkor már gyakran ki kell lépni az egyedi projektek keretéből és a projektet összefüggő programokként kell kezelni (vö. Cleland, 1994; Cleland Ireland, 2002; Görög, 2008). Ennek a megközelítésnek az alapját az a ma már egyre inkább jellemző állapot adja, hogy a változásra már sokszor lehetetlen egyetlen projekt keretében reagálni ${ }^{9}$. Ezért szükséges egymástól különböző, de egymással összefüggő projekteket életre hívni, amik programokká álnak össze.

A három megközelítés azonban csak látszólagosan áll ellentmondásban egymással, hiszen a projektek egyszerre tekinthetők egyedi feladatnak, ideiglenes szervezetnek és stratégiai építőelemnek is. Ez a hármas megközelítés pedig mintegy utólag validálja Fekete és Dubroff (2003) projektdefinícióját, hiszen ennek a tripla értelmezésnek a leképeződése megtalálható benne.

\footnotetext{
${ }^{8}$ A ráépültség mértékbe nagyban függ a választott projektszervezeti formától.

${ }^{9}$ Természetesen előfordulhatnak olyan esetek, amikor egyetlen projekt is elég a változás okozta probléma megoldására.
} 


\section{$2.2 \quad$ A projekt szerepe a szervezetben}

A projekt szerepe a szervezetben az idő előrehaladtával (hasonlóan a definíciójához) megváltozott. Azonban az alapvető célja a külső vagy belső környezet változásaihoz történő adaptáció eszközeit jelentette (Görög, 2003). Ameddig a külső környezet statikus volt (és ebböl fakadóan a belső környezet is stabil, ritkán változó volt), addig a projekt legtöbbször valamilyen projekteredmény ${ }^{10}$ létrehozását jelentette (vö. Fortune-White, 2006; Olsen, 1971). Ez ugyanis már önmagában biztosította a változáshoz való alkalmazkodást. Azonban később, a külső környezet változásával, a statikusság eltünésével ${ }^{11}$ a projektek szerepe is megváltozott. Továbbra is a külső illetve belső környezethez való alkalmazkodás fő eszközének tekintethető a projekt, azonban jelentősebb, inkább stratégiai megközelítést kapott (ld. pl. Judgev-Müller, 2005). Manapság a stratégia fő eszköze a projekt, azonban ez azt vonja magával, hogy a projektnek is stratégiai fókuszt kell kapnia (vö. Cleland, 1994). Ellenkező esetben nem képes biztosítani azt, ami az életre hívásának alapvető célja volt, nevezetesen a vállalat megfelelő módon képes legyen alkalmazkodni a megváltozott feltételekhez. Természetesen ez azt is magában foglalja, hogy a stratégiai menedzsment és a projektmenedzsment szoros kapcsolatban kell, hogy álljon egymással, és a stratéga valamint a projektet tervező személy ${ }^{12}$ egymással összehangoltan dolgozzon. A projekt definíciója is ezt az evolúciót mutatja, hiszen a kezdeti projektháromszögre irányuló definícióból látványos fejlődéssel jutott el a manapság használt, eredmény/szolgáltatás-centrikus definícióhoz.

A teljesség igénye miatt szükséges megemlíteni még azokat a vállalatokat, amelyek részben vagy teljes mértékben projektalapon működnek. Ilyenkor a vállalat az operatív munkavégzése során nem (vagy nem csak) terméket állít elő, hanem szolgáltatást ad el. Tipikus példa a rendezvényszervező cég vagy egy tervezőiroda. Ebben az esetben az alapvető szerepe a projektnek a vállalati bevétel generálása. Azonban csak látszólag fedezhető fel ellentmondás a stratégiaorientáltság és az operatív tevékenység között. Ilyenkor csupán a megrendelő szemszögéből kell nézni

\footnotetext{
${ }^{10}$ A projekteredmény a projekt által létrehozott outputot vagy outputokat foglalja magában.

${ }^{11}$ Ezt föként az 1973-as és 1979-es olajválság okozta.

${ }^{12} \mathrm{Ez}$ a személy legtöbbször a projektmenedzser, azonban vannak olyan vállalatok - föként, amik projektalapon müködnek - ahol a tervező személye és a projektet irányító személy elválik egymástól.
} 
a projektteljesítés folyamatát. Könnyen belátható, hogy a projekttulajdonos ilyenkor is a környezethez való alkalmazkodást tartja fö szempontnak, és az alapján határozza meg követelményeit a projekt alapon müködő cégnek, amelyek mintegy szolgáltatóként szállítja az adott terméket.

A korábban említett alapvető céllal, a környezethez való alkalmazkodással összecseng az a fajta csoportosítás, ami szerint a projektek három kategóriába sorolhatóak. Ennek a csoportosításnak az alapvető lényegét az adja, hogy milyen változás, milyen igény hívja őket elő. A csoportok a következők (Cicmil, 1999; Görög, 2007):

- stratégiai jellegü projektek

• problémamegoldó projektek

• esemény alapú projektek

Az első megközelítés rendszerint olyan beruházást jelent, amely révén a vállalat a stratégiai céljait elérheti (Grundy-Brown, 2002). Ilyen lehet például egy új gyártósor üzembe helyezése vagy egy úgy komplexum megnyitása. A legtöbb klasszikus projekt ebbe a kategóriába sorolható.

A második kategóriát az egyre markánsabb változások hívták életre. Azaz amennyiben valami olyan probléma, megváltoztatni kívánt paraméter merül fel a szervezet életében, amit meg kell oldani, akkor szükséges ezt a típusú projektet életre hívni. Ilyen lehet például egy jogszabályi változás, amely egy gyár esetében a légszennyezés mértékét az eddiginél kisebb szintben rögzíti. Ilyenkor szükséges lehet a problémára reagálni, akár úgy, hogy új légszürőket építenek be a kéményekbe szürni a kibocsátást, akár úgy, hogy új eljárást dolgoznak ki (Görög, 2007).

A harmadik eset az, amikor egy vállalat olyan eseményt vagy rendezvényt szervez, ami nem stratégiából vagy külső problémából fakad, hanem a szervezet alapvető céljával összhangban hívnak életre egy ilyen projektet. Ilyen lehet például az, amikor egy non-profit szervezet megrendezi a szokásos évi fogadását, vagy egy egyetem a gólyabálját (Görög, 2007).

Mindhárom esetben látható, hogy a projekt alapját a változásra való reagálási kényszer vagy a stratégiai, szervezeti igények hívják életre. Így az ellentmondás a fejezet eleje és vége között csak látszólagos, hiszen ez a csoportosítás is a környezethez való alkalmazkodás szerint rendezi kategóriákba a projekteket, csupán 
itt a környezeti változás fakadhat belső forrásból (stratégiából vagy szervezeti kötöttségből ${ }^{13}$ ) vagy külsőből (pl. a jogszabályi változások miatti módosítások szükségessége).

Természetesen a projekteket többféle módon is lehet csoportosítani (ld. pl. Bower - Walker, 2007; Crawford - Pollack; Tuner, 2006), azonban ezek nem projekteredmény tartalma alapján, azaz nem eredményszemlélet alapján kategorizálják a projekteket, hanem azok ismétlődő jellege vagy komplexitása alapján. Így a projektet a projekt alapvető céljával (a környezethez való változásra történő reagálás a projekteredmény létrehozása által) kevésbé vannak összhangban.

Összességében meg lehet állapítani tehát a projekt definíciója és csoportosítása alapján, hogy mindenképp szükséges a folyamat során az eredményszemléletet figyelembe venni, ugyanis ez biztosítja azt, hogy a szervezet realizálja azt a célt, ami a projekt életre hívásának oka volt. Ehhez pedig elengedhetetlenül szükség van megfelelő projektvezetőre, aki rendelkezik a szükséges tudásbeli eszközökkel ennek sikeres vezetéséhez.

\subsection{A projekt szakaszai}

A projektek szakaszokból épülnek fel, köszönhetően annak az immanens sajátosságának, hogy ideiglenesek és meghatározott céllal hívták életre őket. A projekt ebböl fakadóan alapvetően az alábbi szakaszokból épül fel (Görög, 2003; Fekete-Dobraff, 2003; Project Management Institute, 2008; Verzuh, 2008):

- a projekt koncepciójának meghatározása,

- a projekt megtervezése,

- a projekthez szükséges keretek kialakítása,

- a projekt implementálása,

- a projekt lezárása.

Görög (2003) szerint alapvetően négy szakaszra bontható, amelyek az 1. ábra szemlélteti.

\section{1. ábra A projektciklus általános modellje}

\footnotetext{
${ }^{13}$ Természetesen ennek a forrása fakadhat külső változásból, de a közvetlen lecsapódása belső változás által támasztott igény.
} 


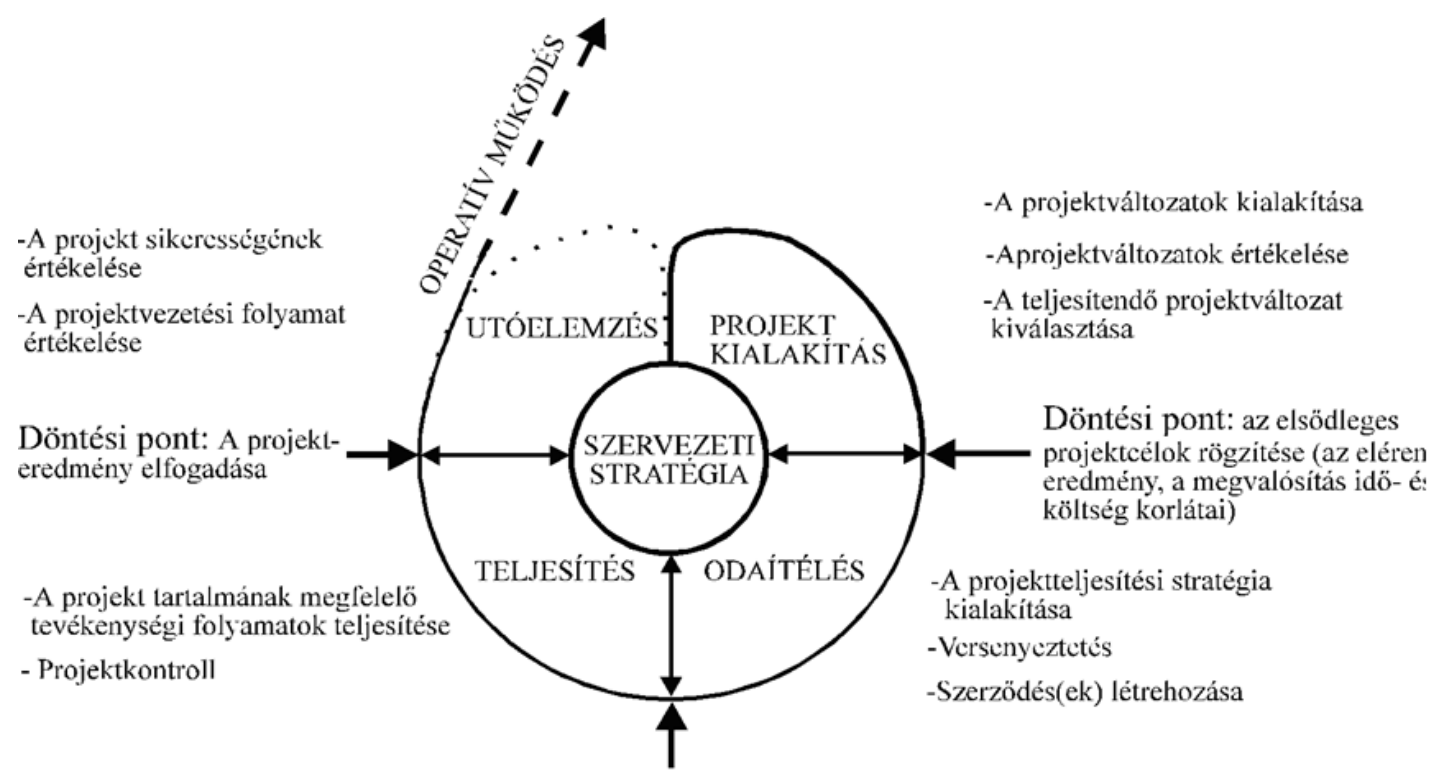

Döntési pont: az elérendö eredményért, a teljesítés időtartamáért és költségciért való felclössćg, illetve az czckkel összefüggő kockázatok allokációjának rögzitése

Forrás: Görög (2003), 65.oldal

Az első fázisban, a projekt tervezésének szakaszában a projekt keretei kerülnek kialakításra. A legfontosabb terméke ennek a szakasznak a projektterv, de egyéb termékek is keletkezhetnek (ilyen például a Projektalapító Dokumentum). A projektterv a következőket tartalmazza (Fekete-Dobreff, 2003; Görög, 2003: Project Management Institute, 2000; 2006, Verzuh, 2008):

- a projekteredmény behatárolása,

-a fontosabb érintettek elemzése (ez természetesen összefügg az előzővel, hiszen a legfontosabb érintettek igényeinek meg kell jelenniük a behatárolás során) és kezelése,

- a projekt tevékenységstruktúrája és a köztük lévő logikai kapcsolatok,

- a projekt idő-, erőforrás- és költségterve,

- a projekt kockázatkezelési politikája,

- a projekt kommunikációs stratégiája,

- a projektszervezet felépítése,

- a projektkontroll módja,

- a probléma eszkalációjának módja,

• különböző dokumentációs kötelezettségek (pl. megbízólevél) és opcionálisan ezek sablonjai. 
Látható, hogy a projektterv formalizált és komoly előkészületet igényel a projektvezetőtől valamint azoktól a személyektől, akik részt vesznek a terv megalkotásában. A legintenzívebb munka a projekt irányítóitól/tervezőitől itt várható el. Természetesen a projektre a legnagyobb mértékủ ráhatást a leggazdaságosabban itt érhetik el a különböző szereplők, ezért célszerü megfelelő módon feltérképezni a külső és belső környezetet, és azt figyelembe venni a tervezés során (Project Management Institute, 2000). Megjegyzendő, hogy Görög (2003)-as modellje összevonja a koncepcióalkotást és a tervezést, és némiképp a keretek kialakítását (pl. az erőforrás megszerzéséhez szükséges keretrendszer kialakítását).

A fázist lezáró utolsó lépés mindenképpen a döntés, amely során az elkészített tervet vagy elfogadják a projekt sorsáról döntő érintettek, vagy módosításra szólítják fel a tervezőket, esetleg elvetik. Amennyiben módosítást/módosításokat kell alkalmazni, akkor természetesen újabb döntés születik később a módosított projekttervröl (Görög, 2003).

Egyes megközelítések a tervezési szakaszt két további részre osztják (ld. pl. Verzuh, 2008), a projekt meghatározására és a terv elkészítésére, tervezésre (ld. 1. ábra). Ennek a megközelítésnek is van létjogosultsága, főleg abban az esetben, amikor a projekt jóval nagyobb mérvű integrációt követel a szervezettől, mint egy egyszerübb projekt esetén (pl. egy integrált informatikai rendszer esetében). Ilyenkor a projekt alapjául szolgáló stratégiai cél és az ebből levezetett elvárt paraméterek (pl megtérülés), amit az üzleti terv tartalmaz, jóval nagyon hangsúlyt kapnak, és nagyobb mértékủ megalapozása lesz a projekteknek ${ }^{14}$. Azonban jelentősen nem változtatja ez meg a tervezési szakaszt, hiszen ugyanúgy magában foglalja a projekt elindításáról, módosításáról vagy elvetéséről szóló döntést, csupán ez két részletben történik meg, egyfelől az üzleti tervről és a projekt alapvető céljának elfogadásáról születik egy döntés, utána pedig a projekttervröl. Amikor a tervezést egy és osztatlan szakaszként kezelik, akkor alapesetben csupán egy döntés születik projektszinten ${ }^{15}$.

\footnotetext{
${ }^{14}$ Bizonyos projektvezetési keretrendszerek, mint pl. a PRINCE2 alkalmazása esetén az üzleti terv mindenképpen kidolgozásra kerül (Molnár, 1997).

${ }^{15}$ Természetesen ez nem zárja ki azt, hogy összvállalati szinten történt már döntés a projekt életre hívásáról, így az üzleti tervről szóló döntés megszületett felsőbb körökben, és ezt már kész tényként prezentálják a projektet tervező csapatnak. Szélsőséges esetben a tervezési szakaszban még ennél is több döntési pont lehetséges, hiszen el lehet fogadni külön a költségtervet, az időtervet, a projektszervezetet, de ennek mechanizmusát mindig a projekt környezete és a döntéshozó érintettek határozzák meg.
} 


\section{2. ábra A standard projektciklus}

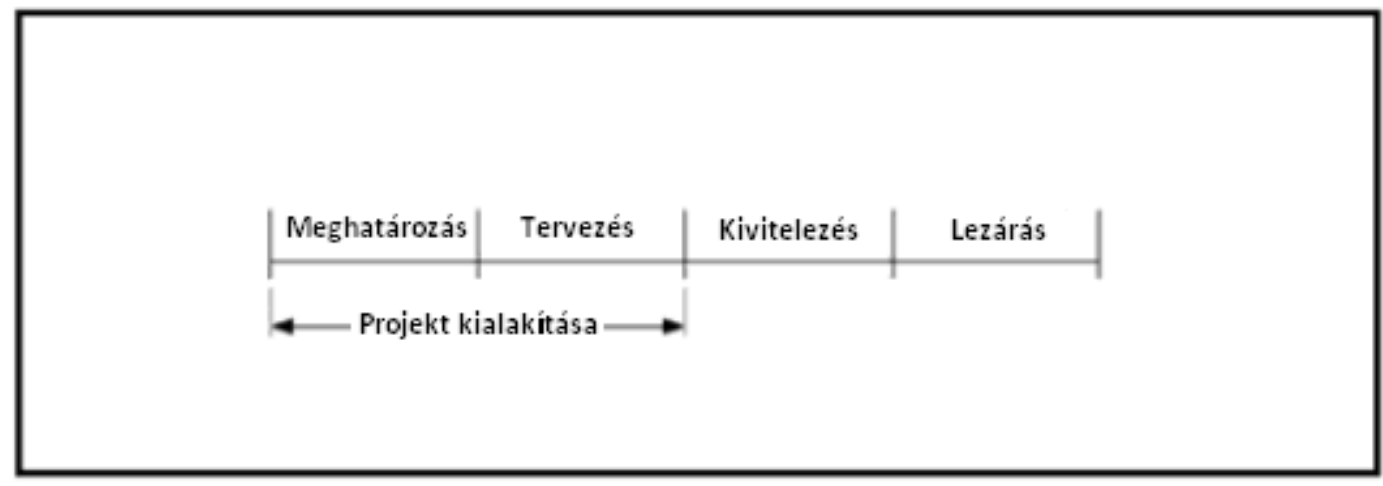

Forrás: Verzuh (2008), 23. oldal

A második szakasz az odaítélés. Ez a fázis csupán külső vagy vegyes projektek esetén található meg (azaz olyan projektek esetén, ahol a projekt nem kizárólag belső erőforrásból kerül megvalósításra), hiszen ennek során kerül kialakításra a külső féllel történő szerződés és elszámolási mód formája, valamint a tenderdokumentum is. Így ennek a fázisnak a legfőbb eredménye a kiválasztott külső közreműködővel vagy kiválasztott külső közremüködőkkel aláírt szerződés lesz. Természetesen itt is van döntési pont, aminek során egyfelöl dönthetnek az alkalmazott szerződésbeli feltételekről, másfelől a tendereztetési feltételekről ${ }^{16}$ (Görög, 2003). Szükséges megjegyezni, kevés szerző említi ezt a szakaszt külön (ld. pl. Rawlings, 1987), hiszen a projekthez szükséges külső erőforrások kiválasztása és megszerzése célját tekintve nem tér el a belső erőforrások kiválasztásától és megszerzésétől. Ezért kezelhető integráltan a tervezéssel, hiszen jellegében nem tér el ettől, még akkor sem, ha óhatatlanul más eszközök kerülnek ilyenkor használatra.

A harmadik szakasz, amely a projektszervezet tagjai számára a legtöbb idő-, és energia-befektetést igényli, az a projekt teljesítése. Ebben a szakaszban kerül megvalósításra a projekteredmény. A projektvezető feladata ilyenkor - a tervezéssel ellentétben - csupán néhány dologra koncentrálódik, de ez a szakasz is tetemes

\footnotetext{
${ }^{16}$ Amennyiben ez a szakasz szükséges, azaz a vállalat nem képes (vagy nem éri meg neki) belső erőforrásokkal megvalósítani, és nem éri meg internalizálni a piacon fellelhető erőforrásokat, akkor mindenképpen szükség van arra, hogy külső közremüködőt vegyen igénybe. Így arról, hogy szükséges-e ez vagy sem ilyet igénybe venni, nem érdemes vitatkozni. Csupán a feltételekről. Természetesen a tendereztetés nem kötelező, ennek szükségességéről mindig a hatályos jogszabály dönt.
} 
időráfordítást igényel tőle. A főbb feladatai ilyenkor a következők (lsd. pl. Fekete, 2000; Görög, 2003, Project Management Institute, 2006):

- a projektterv során definiált tevékenységek kivitelezése,

-a kockázatkezelésnek ebben a fázisban kivitelezésre kerülő lépéseinek megtétele,

- a projektkontroll kivitelezése (mind eredmény-, mind pedig folyamatkontroll, azaz a projekteredmény önmagában is mérhető egységeit érintő minőségi ellenőrzés, illetve a hatékonyság, azaz az időbeli és költségbeli teljesülés ellenőrzése),

- folyamatos egyeztetés a projektcsapat tagjaival és a föbb érintettekkel,

- folyamatos jelentés,

- egyeztető értekezletek életre hívása és levezénylése,

- probléma eszkalációja, ha szükséges,

- módosítások kitalálása és alkalmazása, amennyiben szükséges,

- amennyiben a szerződéses feltételek úgy kerültek kialakításra, akkor a teljesítmény elszámolása a külső közremüködők esetén.

Természetesen könnyen előfordulhat, hogy a projekt ezen szakaszában megjelennek iteratív tevékenységek is, ilyen például az érintettek elemzésének felülvizsgálata vagy a kockázatelemzés (vö. a projektterv tartalmával).

A döntési pont jelen esetben a projekteredményhez, a projekt legfőbb termékéhez köthető, nevezetesen átvételre kerül-e vagy elutasítják. Utóbbi esetben vagy a projekt teljes leállítása, vagy módosításra való felszólítás történik - de természetesen ezek megtörténhetnek teljesítés közben is (Görög, 2003).

A projektciklus utolsó szakasza az utóelemzés (ezzel párhuzamosan történik a projekteredmény használatba vétele). Egyes források lezárásnak hívják. Ebben a fázisban valósul meg a projekt egészének értékelése mind hatékonysági, mind hatásossági szempontok alapján. Természetesen ebben a szakaszban nincs döntési pont, maximum a projekt folyamatát és teljesülését érintő elemzések elfogadása vagy elvetése történik. Fontos termékei a szakasznak szükséges lezáró, értékelő dokumentumok (mint pl. a projektzáró dokumentum), hiszen ennek a tapasztalatok összegzésénél és megörzésénél fontos szerepe van (lsd. pl. Görög, 2003, Project Management Institute, 2000). 
Ezekből világosan látszik, hogy a projektmenedzseri tudás rendkívül szerteágazó és komplex tényező, amelyet lehetetlen egyetlen dimenzió köré szükíteni. A projektmenedzsernek számtalan ismeretet és képzettséget kell elsajátítania képzése és gyakorlati munkavégzése során, különben a projekt óhatatlanul sikertelenségre van kárhoztatva ${ }^{17}$.

Szükséges megjegyezni, hogy a klasszikus projektszakasz-tipológiák mellett egyéb megközelítések is születtek. Ilyen van den Ende és van Marrewijk (2014) megközelítése, amely négy szakaszt különböztet meg, úgymint:

• kezdeményezést és az életképességi tanulmányok elkészítését,

- megvalósítást,

• müködési próbát és

- lezárást és átadás/átvételt.

Az első szakaszba a klasszikus tervezési eszközöket érti a projektvezető (beleértve a tenderezést is). A második szakasz során kerül megvalósításra a projekt. A harmadik szakaszban kerül tesztelésre a projekteredmény. Klasszikus beruházás esetén a tesztelés során meg lehet különböztetni hideg- és melegpróbát, amikor a projekteredményt először anyagok (vagy egyéb, a gyártás során használandó erőforrások) nélkül kerül kipróbálásra, míg a melegpróba esetén már erőforrásokkal. Végül a projekt tulajdonosa átveszi a projektet. Természetesen amennyiben a harmadik szakasz során a projekteredményben hibát észlel a projekttulajdonos, akkor azok kijavítása meg kell, hogy történjék, enélkül a negyedik szakasz nem léphet életbe.

Megállapítható azonban, hogy ez a megközelítés jellegét tekintve nem tér el a korábban említett megközelítésektől, hiszen „csupán” a tesztelést, azaz a müködési próbát tekintve tér el a korábban megfogalmazott projektszakasz-tipológiáktól.

Ehhez hasonló megközelítést alkalmaz a projektszakasz-megközelítésre Buttrick (2000), aki a következő szakaszokat különbözteti meg:

• ötletgenerálás,

- elő-életképességvizsgálat,

• életképesség-vizsgálat,

17 Még akkor is, ha a projektcsapat tagjai sok esetben jelentős segítségére lehetnek a projektmenedzsernek. 
- fejlesztés és kivitelezés,

• komissiózás,

• projekteredmény használatba vétele és

• használatba vétel utáni értékelés.

Az ötletgenerálás megfelel Verzus (2008) meghatározásnak, azaz a projektötletek - az üzleti igényekkel összhangban - ekkor kerülnek meghatározásra. A második lépésben ezeket az ötleteket vizsgálják életképesség szempontjából, míg a harmadik szakaszban az életképesség-vizsgálat (és az üzleti igények) alapján leginkább megfelelő kerül kiválasztásra. A negyedik szakasz a projekt megvalósítása, amely jellegét tekintve megfelel a korábban bemutatott koncepcióknak. Az ötödik szakasz kiemeli a megvalósításból - hasonlóan van den Endéhez és van Marrewijkhoz (2014) a müködési környezetben tesztelést. Természetesen ez leginkább stratégiai projektek esetén értelmezhető, azonban eseményalapú projekteknél is lehet föpróbát tartani vagy egyéb módon tesztelni az eredményt. Bár ilyenkor a teszt lényegesen korlátozottabb. Ezek után történik a használatba vétel. Végül pedig az utóértékelés történik. A szerző kiemeli, hogy ez körülbelül 9-15 hónappal a használatba vétel után történhet meg pontosan. A folyamatot a 3. ábra szemlélteti: 
3. ábra: A projekt életciklusának egyéb megközelítése

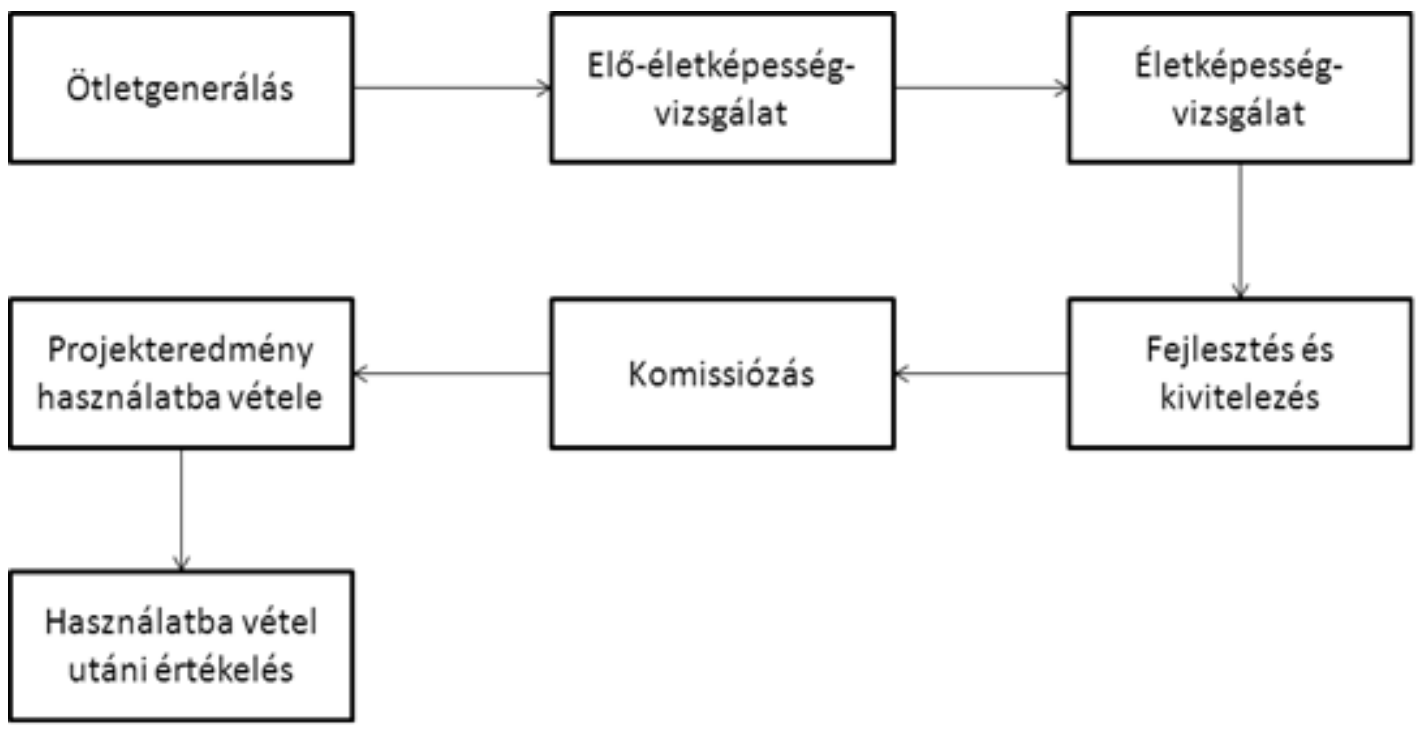

Forrás: van den Ende - van Marrewijk (2014) alapján

Hasonlóan a korábbi szakaszhoz, lényegét tekintve ez a megkülönböztetés sem rejt magában jellegét tekintve új folyamatot, „csupán” megbontja a korábbiakat. Ennek kiemelt szerepe főként a beruházási vagy jelentős, stratégiai projektek esetén lehet, hiszen jobban ráirányítja a figyelmet a kritikus folyamatokra (megfelelő projekteredmény kiválasztása és tesztelés).

Jellegében eltérő megközelítést alkalmaz azonban Labuschagne és Brendt (2005), hiszen a szerzőpáros a korábbi projektciklus-értelmezéseken túllépve a projekt használatba vételét követő szakaszokra is ráirányítja a figyelmet, lévén nem a projektet, hanem a projekteredményt helyezi a középpontba. Ebből fakadóan a következő négy fázist definiálja:

- részletes tervezés,

- kivitelezés,

- a projekteredmény müködése és fenntartása,

- a projekteredmény kivezetése.

Az első két szakasz megfeleltethető a korábbi projektciklus-értelmezések egyes szakaszainak (tervezés, kivitelezés), az újdonságot az utolsó két szakasz jelenti. Azonban, ha elfogadjuk a klasszikus projektértelmezéseket, könnyen belátható, hogy az utolsó két szakasz már nem képezi a részét a projektnek. Ezért ez a megközelítés - a projektmenedzsmentet tekintve helytelen - azonban 
mindenképpen érdekes, hiszen ráirányítja a figyelmet a projekt utóéletére. Ennek különösen akkor lehet létjogosultsága, ha a projekteredmény valamilyen módon kiemelt fontossággal bír. Ilyenre lehet példa (a szerzők értelmezése szerint is), amikor a fenntarthatóság eszméi leképeződnek a projektben (vö. Gareis, 2008; Gareis, 2010a; Kerekes, 2007). Így megállapítható, hogy ez a fajta felfogás egyszerre túllép a projektciklus-közelítéseken és elégtelenül veszi figyelembe a projektek életciklusát, hiszen integráltan, az operatív vezetéssel (ld. 2.4 szakasz) egyben kezeli a projekteredményt.

Ehhez hasonlóan vizsgálja a projektciklust Grillitsch et. al. (2007). A szerzők a tudásmenedzsment elemeit építik be a projektciklusba, hiszen öt szakaszt különböztet meg, úgymint:

- projektötlet kialakítása,

- a projektötlet kialakításához a régebbi tapasztalatok felhasználása,

- projektfeladatok kialakítása,

- teljesítés,

- tanulságok levonása.

A második szakasz során a régebbi projektek során szerzett tapasztalatokat gyüjtik össze, és ez alapján kerül meghatározásra a harmadik szakasz (ez lényegét tekintve megfeleltethető Verzuh (2008) tervezés szakaszának). Végül pedig a tanulságok levonása segíti, hogy a következő hasonló projekt hatásosabban és hatékonyabban kerüljön kivitelezésre. Ebben az esetben a projektvezető feladatai közé tartozik (az ún. projektmérnökökkel [Fehér, 2004]), hogy a tapasztalatokat összegyüjtsék.

Egyes szerzők kiemelik a kontrollt mint tevékenységet (ld. pl. Wysocki, 2013), azonban könnyen belátható, hogy a kontroll jellegét tekintve a megvalósítás része. Még akkor is, ha az agilis projektvezetési eljárás (vö. Aljaz, 2013) miatt a projekt során a behatárolást és kivitelezést iteratív tevékenységnek tekintik.

A klasszikus, eddig bemutatott (ún. waterfall) projektvezetési megközelítésektől kissé különböző megközelítést képvisel az agilis projektvezetési módszer, amely során a projekt szakaszai a következőképpen alakulnak (ld. pl. Wysocki, 2013):

- projekt kezdeményezése, 
• prioritási listák meghatározása,

- tervezés és fejlesztés,

-kiértékelés,

-visszacsatolás,

•új funkcionális eredmények prezentálása,

- projekt lezárása.

Az egyetlen új szakaszt a második jelenti, amely során a vevővel közösen az egyes projekteredmény-elemek fontosság szerinti sorrendbe rakása történik. Majd a legfontosabb kerül tervezésre, fejlesztésre, kiértékelésre, visszacsatolásra és átadásra. Ezek után ismét a második szakasz következik, addig, amíg az összes szükséges projekteredmény-elem leszállításra nem kerül. Ekkor a projekt lezárása megtörténik. Ez a fajta projektszakasz megközelítés föként az IT-ben terjedt el, ahol az egyes projekteredmény-elemek között felállítható prioritás és lefejleszthető a projekteredmény jelentős funkcionalitásbeli csökkenése nélkül (vö. Aljas, 2013). Ezt a folyamatot szemlélteti a 4 . ábra:

4. ábra: Az agilis projektvezetési módszertan projektszakaszai

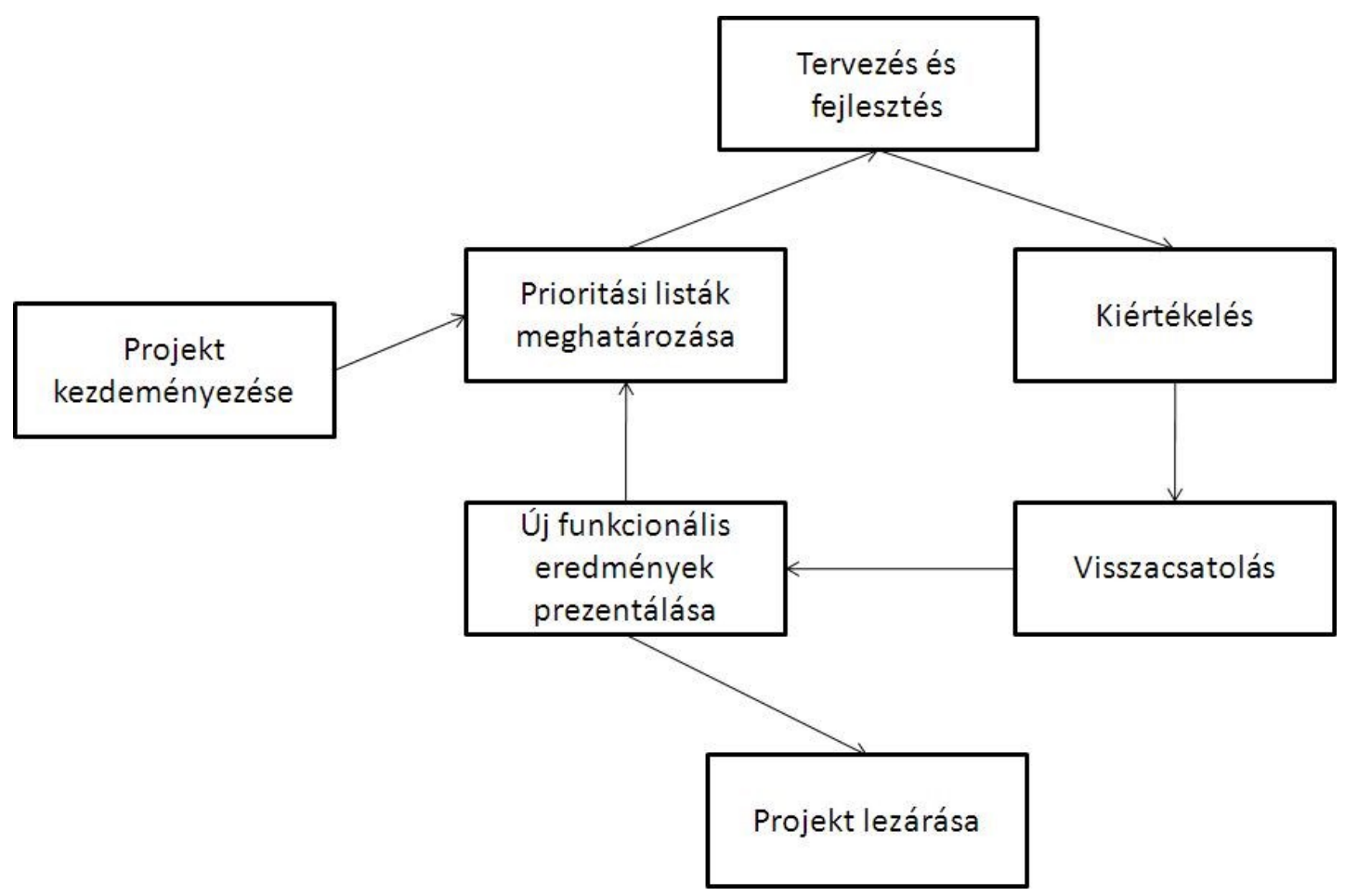

Forrás: Wysoczki, 2013 alapján 
Megállapítható azonban, hogy ez a fajta megközelítés sem tér el jellegét tekintve a klasszikus projektfolyamat-megközelítésektől, csupán projektet hoz létre a projektben, azaz kisebb részegységekre bontják a projekteredményt, és mindegyiket kvázi külön projektként kezelik.

Összességében megállapítható tehát, hogy a projekt szakaszai a következők:

- tervezés,

$\bullet$ kivitelezés,

- projekt lezárása.

Természetesen mindegyik szakasz további részegységekre bontható. A tervezést meg lehet bontani koncepcióalkotás, részletes tervezés, odaítélés szerint. A kivitelezést megvalósítás, kontroll és tesztelést szerint. Míg a projekt lezárását tekintve használatba vétel, tapasztalatok összegyüjtése és utóértékelés szerint. Azonban ezek az alegységek jellegüket tekintve ugyanezek, így kijelenthető, hogy a klasszikus projektek (és némiképp az új, agilis megközelítést alkalmazó projektek is) három szakaszra bonthatók, amelyet a 5. ábra szemléltet:

5. ábra: A projektfolyamat ciklusai

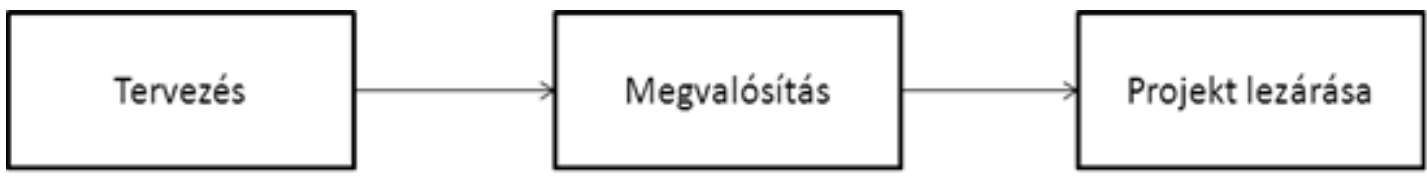

Forrás: saját szerkesztés

Összességében megállapítható, hogy ez a három szakasz, amely minden szakirodalomban megtalálható, azonban mindegyik további részekre bontható. Ez függ a választott iparágtól (vö. Judgev-Müller, 2005), az alkalmazott projektmódszertantól (vö. Wysocki, 2013), a projekt során elérendő céltól (vö. Labuschagne - Brendt, 2005) és a projekt jellegétől (vö. Görög, 2008; Verzuh, 2008).

\subsection{A vezetési dimenziók különbségei}

Bár a projektek vezetése mutat hasonlóságot a vállalatvezetés során alkalmazott diszciplínákkal, azonban a projektek sajátosságai miatt számos különbség is adódik. Így elengedhetetlenül szükséges, hogy a szervezetekben tapasztalható vezetési dimenziók összehasonlításra kerüljenek. 
A vállalatok irányítása során a klasszikus és az újabb értelmezések is három különböző vezetési dimenziót különböztetnek meg (Görög - Smith, 1999), úgymint:

- stratégiai menedzsment,

- projektmenedzsment,

- operatív menedzsment.

A főbb különbségeket Görög (2008) összegezte (lsd. 1 táblázat).

1. táblázat: A vezetési dimenziók összehasonlítása

\begin{tabular}{|c|c|c|c|}
\hline $\begin{array}{c}\text { Az } \\
\text { összehasonlítás } \\
\text { szempontjai }\end{array}$ & $\begin{array}{l}\text { Stratégiai } \\
\text { vezetés }\end{array}$ & Projektvezetés & $\begin{array}{l}\text { Operatív } \\
\text { vezetés }\end{array}$ \\
\hline $\begin{array}{l}\text { A döntések } \\
\text { időhorizontja }\end{array}$ & hosszú távú & középtávú & rövid távú \\
\hline $\begin{array}{l}\text { Hatása a } \\
\text { szervezet } \\
\text { egészére }\end{array}$ & $\begin{array}{c}\text { hosszútávon } \\
\text { jelentős }\end{array}$ & $\begin{array}{c}\text { középtávon } \\
\text { jelentős }\end{array}$ & $\begin{array}{l}\text { rövidtávon } \\
\text { jelentős }\end{array}$ \\
\hline $\begin{array}{l}\text { A tevékenység } \\
\text { meghatározó } \\
\text { tényezője }\end{array}$ & $\begin{array}{l}\text { a várható } \\
\text { jövőbeni } \\
\text { müködési } \\
\text { környezet }\end{array}$ & $\begin{array}{c}\text { kedvező } \\
\text { változás az } \\
\text { elérendő } \\
\text { eredménytarta- } \\
\text { lom révén adott } \\
\text { költség- és } \\
\text { időkorlátok } \\
\text { mellett }\end{array}$ & $\begin{array}{c}\text { a rendelkezésre } \\
\text { álló erőforrások } \\
\text { és/vagy az } \\
\text { aktuális piaci } \\
\text { helyzet }\end{array}$ \\
\hline $\begin{array}{l}\text { A tevékenység } \\
\text { jellege }\end{array}$ & $\begin{array}{l}\text { komplex, } \\
\text { innovatív }\end{array}$ & $\begin{array}{l}\text { komplex, } \\
\text { innovatív }\end{array}$ & $\begin{array}{l}\text { rutinszerü, } \\
\text { szabályozott }\end{array}$ \\
\hline $\begin{array}{l}\text { A tevékenység } \\
\text { folyamatossága }\end{array}$ & $\begin{array}{c}\text { kvázi } \\
\text { folyamatos }\end{array}$ & $\begin{array}{l}\text { egyszeri, } \\
\text { visszatérő }\end{array}$ & folyamatos \\
\hline $\begin{array}{l}\text { A tevékenység } \\
\text { mozgástere }\end{array}$ & $\begin{array}{l}\text { a szervezet } \\
\text { egésze }\end{array}$ & $\begin{array}{c}\text { a szervezet } \\
\text { egésze vagy } \\
\text { több } \\
\text { funkcionális }\end{array}$ & $\begin{array}{c}\text { egy-egy } \\
\text { funkcionális } \\
\text { (szervezeti) }\end{array}$ \\
\hline
\end{tabular}




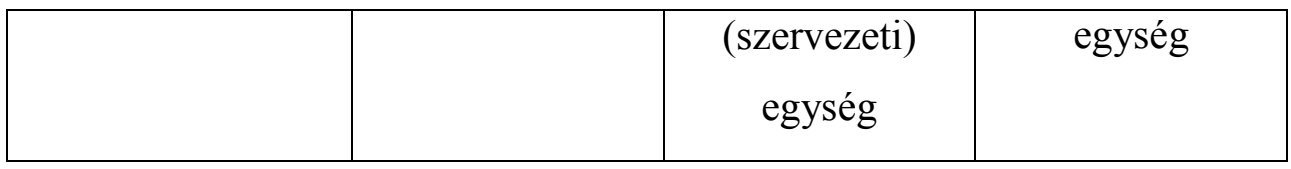

Forrás: Görög (2008), 20. oldal

Ebből a táblázatból is világosan látszik, hogy a három menedzsment jelentősen eltér egymástól - de természetesen egymással megegyező jellemzőkkel is bírnak. A három különbözö menedzsment jelenléte egyidejüleg szükséges ahhoz, hogy eredményes szervezetről beszéljünk, néhány esetben (föként a méretet tekintve kisebb vállalkozások esetében) a három szerepkörből kettőt vagy többet ugyanaz a személy vagy ugyanazok a személyek töltenek be. Azonban a nagyobb vállalatok esetében az eltérő kompetenciák okozta különbség miatt eltérő személyek végzik a feladatokat.

Ehhez hasonló különbségtételt tesz Labuschagne és Brandt (2005), amelyet az alábbi táblázat szemléltet:

Az 1. táblázatból is megállapítható, hogy a stratégiai menedzsment fő fókusza a hosszabb távú célok meghatározása és ezek realizálása ${ }^{18}$. Ebből fakadóan a haszna is főként hosszú távon realizálódik. További fontos jellemzője, hogy a szervezet egészét érintő változásokat vezet be, például termékpalettát bővít vagy költséget racionalizál (1sd. pl. Antal-Mokos et. al., 2003; Mészáros, 2005). Legfontosabb jellemzői közé tartozik a stratégiát alkotó személyeknek a jó elemzőkészség ${ }^{19}$ és a kockázatvállalás hajlandósága.

\footnotetext{
${ }^{18}$ Fontos megjegyezni, hogy az időhorizont iparáganként eltérő lehet, hiszen míg az IT egyes szektoraiban (pl. az online marketing esetében) a stratégia akár éves ciklusú is lehet, addig a klasszikus, érett iparágak esetén ez 3-5 év, hosszú távú stratégia esetén akár 10 évet is felölelhet (vö. Antal-Mokos et. al., 2003; Chickán - Czakó, 2009; Mészáros, 2005).

${ }^{19}$ Ez a kifejezés már önmagában is eléggé összetett, azonban mibenlétének vizsgálata és taglalása túlmutat az értekezés keretein.
} 
2. táblázat: A projekttevékenység és az operatív müködés jellemzői

\begin{tabular}{|c|c|}
\hline Projekttevékenység & Operatív müködés \\
\hline Új terméket állít elő. & Ugyanazt a terméket állítja elő. \\
\hline $\begin{array}{c}\text { Meghatározott kezdettel és befejezéssel } \\
\text { rendelkezik. }\end{array}$ & Folyamatos tevékenység. \\
\hline Több tudományterület ismeretét igényli. & Specifikus tudást igényel. \\
\hline Ideiglenes csapat. & Permanens szervezet. \\
\hline Egyediség. & Ismétlődő és jól ismert. \\
\hline $\begin{array}{c}\text { Terv szerint dolgozok meghatározott } \\
\text { költséggel. }\end{array}$ & Éves költségterv alapján dolgozik. \\
\hline $\begin{array}{c}\text { Megszüntetik, ha az előzetes célok nem } \\
\text { teljesülnek. }\end{array}$ & $\begin{array}{l}\text { A folyamatos müködés majdnem minden } \\
\text { körülmény ellenére biztosítva van. }\end{array}$ \\
\hline $\begin{array}{l}\text { Nehéz meghatározni és betartani a } \\
\text { költségét és befejezésének idejét. }\end{array}$ & $\begin{array}{l}\text { Az éves kiadások a korábbi tapasztalatok } \\
\text { alapján kerülnek meghatározásra. }\end{array}$ \\
\hline
\end{tabular}

Forrás: Labuschagne - Brandt (2005), 165. oldal

Ezzel szemben az operatív menedzsment fó funkciója, hogy a napi, operatív feladatok (termelés, pénzügy stb.) rendben, hatékonyan és hatásosan menjenek ahogy az 1. és 2. táblázatból is látszik. Fontos, hogy az időhorizont, amiben az operatív vezetés létezik, rövid távú, ebböl fakadóan föként rövid távú hasznosságot maximalizáló kompetenciákkal rendelkeznie az itt működő vezetőnek (a funkcionális vezetőnek). További jellemzője, hogy funkcionális szervezet esetén egy-egy adott szervezeti egység keretein nem nyúlik túl (vö. Dobák, 2006). Lehetővé válik továbbá (különösen funkcionális szervezet esetén), hogy a vezető nem csak az emberek irányításához ért, hanem az adott szervezeti egység szakmai tartalmához kapcsolódó jártasságokat is bizonyos szintig birtokolja (vö. Bakacsi, 2004). Ennek köszönhetően a feladatokat megfelelö módon tudja allokálni a megfelelő személyeknek. Ennek sokszor előfeltétele lehet az, hogy át kell transzformálni a felsőbb szintü, sokszor nehezen leképezhető vezetői utasításokat az adott egység kulturális sajátosságainak megfelelően ahhoz, hogy mindenki képes legyen a neki 
allokált feladatokat ellátni. Ehhez pedig elengedhetetlenül szükséges szakmai, analitikus és emberek menedzseléséhez köthető képesség is.

Összességében meg lehet állapítani tehát, hogy míg a stratégiai vezetéshez kötődő képességek föként a komplexitás és innovatív feladatok ellátásához kapcsolódnak, addig az operatív menedzsment föként a rutinszerü és jól szabályozott feladatok ellátásához köthető.

A projektmenedzsment időhorizontban a kettő között helyezkedik el. Némiképp ötvözi is a másik kettő sajátosságait, hiszen stratégiai változásokat kell végrehajtani a funkcionális egység vagy egységek szintjén. Ebből fakadóan megőrzi a projektfeladat a stratégiai menedzsment komplexitását és innováció-centrikusságát, azonban óhatatlanul magán viseli az operatív menedzsment szabályszerü jellegét (ennek mértéke természetesen projektről projektre változik), valamint kapcsolatba kerül szorosabban is az adott funkcionális egység vagy egységek tagjaival (vagy legalább vezetőivel ${ }^{20}$ ).

A projektmenedzsment azonban nem csak technikailag, hanem tartalmilag is megteremti a kapcsolatot az operatív és a stratégiai vezetés között (Görög, 2003). Amennyiben a stratégiai célok megfogalmazódnak ${ }^{21}$, projekteket hívnak életre, amelyek hatása az operatív menedzsment szintjén csapódik le. Például egy költségcsökkentést előirányzó stratégiai cél megjelenhet egy szervezet átalakítási projekt kapcsán, aminek keretében egy vagy több funkcionális osztály vagy alosztály müködése kerül racionalizálásra. Szükséges felhívni a figyelmet arra a tényre, hogy nem csak a szervezet felső szintjéről érkezhetnek stratégiai kezdeményezések. Megfelelő vállalati kultúrával rendelkező vállalat esetén a középvezetők vagy az operatív vezetők, sőt, szélsőséges esetben akár a dolgozók is kezdeményezhetnek szervezeti változásokat, ezáltal generálhatnak projekteket (Earl, 1989; 1996). Azonban még az ilyen cégek esetén is kiveszik a projekt behatárolását és vezetését a kezükből és erre szakosodott emberek segítenek az ötletet átalakítani valós projektté ${ }^{22}$.

\footnotetext{
${ }^{20}$ Ezt nagyban befolyásolja a projekt teljesítésének alapjául szolgáló szervezet.

${ }^{21}$ Ennek pontos mibenlétét ld. pl. Antal-Mokos et al, 2003; Mészáros, 2005; Kiss - Molnár Klimkó, 1993)

${ }^{22}$ Természetesen csak abban az esetben, amennyiben a projekt alapjául szolgáló ötlet életképesnek bizonyult a döntést meghozó bizottság vagy személy előtt.
} 


\subsection{A projektvezetés megközelítése}

Minden vállalati tevékenységet szükséges valamilyen fokon irányítani. Korábban bemutatásra került az a három alapvető típus, ami alapján meg lehet különböztetni a vállalati vezetés egyes aspektusait, dimenzióit.

A projektmenedzsment jól láthatóan az összhangot, a kapcsot jeleníti meg a kettő között, hiszen a stratégia által meghatározott célokat ülteti át operatív környezetbe. Azonban a projektmenedzsment jelentése ennél jóval tágabb, az évek során számtalan megközelítés született arról, hogy ez a fogalom mit jelent:

- „A projektmenedzsment a projekt tevékenységeinek végrehajtása során a tudás, a képességek, az eszközök és a technikák alkalmazása a projekt követelményeinek teljesítése céljából.” (Project Management Institute, 2006, 24. oldal)

- „A szervezetek irányításában kialakult olyan vezetési tevékenység, és egyben a vezetéstudomány önállósult területe, amely eltérően egy szervezet operatív tevékenységeinek folyamatos, bizonyos vonatkozásban rutinszerünek nevezethető irányítási módjától, elsősorban a szervezeti stratégia által életre hívott egyszeri, komplex feladatok teljesítésével foglalkozik.” (Görög, 2003, 363. oldal)

Ezek alapján megállapítható, hogy a projektmenedzsment elsődleges feladata a vezetőség által meghatározott keretek között sikerre vinni a projektet. Természetesen elöfordulhat, hogy a projekt feltételei útközben változnak, ezért szükséges, hogy rugalmasan alkalmazkodjon a környezethez. Emellett feladatai közé sorolható, hogy ne csak sikerre vigye a projektet, hanem koordinálja, irányítsa is, azaz ne csak hatásosan, de hatékonyan is menedzselje. Így a projektvezetés feladatai közé sorolható többek között (vö. Fekete - Dobreff, 2003; Kiss et. al., 1993b; Project Management Institute, 2000;2006):

- a projekt koordinációja,

- a projekt munkaterjedelmének behatárolása

- a projekt időtartamának és költségének megtervezése,

- a projekt időtartamának és költségeinek kontrollja

- a minőségbiztosítási feladatok ellátása,

- a kommunikációs feladatok ellátása, 
• a kockázatok menedzselése,

• a külső erőforrások menedzselése.

Ez összhangban áll a projekt értelmezésének fejlődésével összhangban lévő projektvezetői feladatértelmezés. Ugyanis amennyiben a projekt mint egyedi feladat kerül meghatározásra, akkor a projektvezető fö feladata a projektteljesítési folyamat vezetése (vö. Project Management Institute, 2008). Amennyiben a projekt mint ideiglenes feladat kerül meghatározásra, akkor a projektvezető fő feladata ennek az ideiglenes szervezetnek a vezetése (vö. Lundin - Söderlund, 1995). Amennyiben pedig a projekt mint stratégiai építőelem kerül meghatározásra, akkor a projektvezető fő feladata a kedvező változás realizálásának menedzselése. Természetesen (ahogy a projekt értelmezése is) ezek nem egymást kizáró, hanem egymást kiegészítő, egymással átfedésben álló szerepkörök. Az értelmezések, szerepkörök és projektciklusok összehangolását 3. táblázat ábra szemlélteti: 
3. táblázat: A projekt értelmezésének, szakaszinak és a projektvezető

feladatainak összehangolása

\begin{tabular}{|l|l|l|}
\hline $\begin{array}{l}\text { Projekt értelmezésének } \\
\text { közelítésmódja }\end{array}$ & Projektvezető feladatai & $\begin{array}{l}\text { Projektszakasz, amiben a } \\
\text { feladat megjelenik }\end{array}$ \\
\hline $\begin{array}{l}\text { Projekt mint egyedi } \\
\text { feladat }\end{array}$ & $\begin{array}{l}\text { Projekt } \\
\text { munkaterjedelmének } \\
\text { behatárolása } \\
\text { Projekt időtartamának és } \\
\text { költségének megtervezése } \\
\text { Projekt időtartamának és } \\
\text { költségének kontrollja } \\
\text { Projekt koordinációja } \\
\text { Minőségbiztosítási } \\
\text { feladatok ellátása } \\
\text { Külső erőforrás } \\
\text { menedzselése }\end{array}$ & Projekt tervezése \\
Projekt kivitelezése \\
\hline $\begin{array}{l}\text { Projekt mint ideiglenes } \\
\text { szervezet }\end{array}$ & $\begin{array}{l}\text { Projekt koordinációja } \\
\text { A krojekt kivitelezése } \\
\text { feladatok ellátása }\end{array}$ & Projekt kivitelezése \\
\hline $\begin{array}{l}\text { Projekt mint stratégiai } \\
\text { építóelem }\end{array}$ & $\begin{array}{l}\text { Projekt terjedelmének } \\
\text { behatárolása }\end{array}$ & Projekt kivitelezése \\
\hline
\end{tabular}

Forrás: saját szerkesztés

Az ábrából megállapítható, hogy melyik nézet melyik projektvezetői feladatot teszi szükségessé, és ez melyik szakaszban jelenik meg. Természetesen ez nem azt jelenti, hogy az adott projektvezetői feladat csak és kizárólag aszerint a projektértelmezés szerint kerül kivitelezésre, hiszen ha a projektet mint ideiglenes feladat kerül értelmezésre, akkor is óhatatlanul szükséges a tervezés és ennek kivitelezése. Azonban a hangsúly ilyenkor a projektszervezet vezetésére, azaz a kommunikációra terelődik. Továbbá szükséges megjegyezni, hogy az azonosított projektszakasz is hasonlóan lett kezelve, mint a projektvezető feladata, azaz csak a domináns szakasz került meghatározásra. Például a kontroll esetében a tervezés során kerül meghatározásra az alapul szolgáló norma, azonban a legmarkánsabban ez a feladatkör a kivitelezés során jelenik meg.

Mindezekből megállapítható, hogy a projektek vezetése mint feladat igen összetett, és kiterjedt tudást kíván, amely a 4. fejezetben kerül kifejtésre. 


\subsection{Az agilis projektvezetési módszertan rövid bemutatása ${ }^{23}$}

A klasszikus, waterfall megközelítésektől (ld. pl. a PMBOK [Project Management Institute, 2008]) eltérő filozófiát követ az agilis projektvezetési módszertan (vö. Aljas, 2013; Wysocki, 2013). Az előbbi lényege, hogy a projekt szakaszai jól elkülönülten (ld. 2.4-es fejezet), egymás után kerülnek kivitelezésre. Azaz először a tervezés, aztán a megvalósítás, végül pedig a projekt lezárása (ld. 5. ábra). Az agilis projektvezetési módszertan ezzel szemben a projektet részeredményre bontja, és mintegy projekteteket alakít ki a projektben (vö. 4. ábra). Ennek következtében a megváltozott környezeti feltételekre, és ebből fakadóan a megváltozott vevői (projekttulajdonosi) igényekre jobban tud reagálni a projekt. Ennek feltétele a vevővel (projekttulajdonossal) való szoros kooperáció.

$\mathrm{Az}$ agilis projektvezetési módszertan azonban nem csak a projektfolyamatokat tekintve tér el a klasszikus, waterfall megközelítésektől (vö. Wysocki, 2013). Három fontos tényezőt lehet még említeni. Az egyik, hogy a projektcsapat szerepe megváltozik. A projektcsapat tagjaira jóval nagyobb felelősség hárul, hiszen a prioritási listák alapján meghatározott projekteredmény-elemek tervezése, a feladatok meghatározása és azok allokálása, valamint azok megvalósítása is általában az ő felelősségük. Ez pedig felértékeli a csapat. Másik tényező (ebből fakadóan) a projektvezető megváltozott szerepe. Mivel a tervezést és ennek kontrollját a projektvezető helyett a projektcsapat végzi, így legfőbb feladata a koordináció, a támogató szerepkör betöltése. Azaz minden olyan nehézség elhárítása, amely gátolná a projektteljesítést. Szükséges megjegyezni, hogy a projektcsapaton belül is van általában vezető, egy ún. scrum-master, aki betölti a klasszikus projektvezetői funkciók egy részét (kontroll, feladatok delegálása), azonban a projektmunka elvégzésében (pl. programozás) is részt vesz. Harmadik tényező, hogy a projektcsapat nem kerül feloszlatásra a projekt befejezését követően, hanem új projekthez lesznek delegálva. Ez jelentősen elő tudja segíteni a tapasztalatok megőrzését és az összeszokottság révén a hatékonyabb munkavégzést (vö. Dobák, 2006).

Könnyen előfordulhat azonban, hogy a szervezet nem teljes mértékben adaptálja az agilis projektvezetési módszertant, hanem csak egyes részeket emel át

\footnotetext{
${ }^{23} \mathrm{Az}$ agilis projektvezetési módszertan részletes bemutatása nem képezi a dolgozat tartalmát, azonban a gyakorlati rész miatt óhatatlanul szükséges rövid jellemzése.
} 
belöle. Pl. a projektet részeredményekre osztja, de a klasszikus projektvezetői szerepkört meghagyja (vagy legalábbis nagy részét).

Összességében azonban megállapítható, hogy az agilis projektvezetési módszertan esetében a projektcsapat fontossága felértékelődik (vö. Wysocki, 2013), még akkor is, ha a projektvezető feladatai változatlanok (vagy majdnem változatlanok) maradnak. Köszönhetően annak, hogy a véleményük, tudásuk jobban figyelembe vételre kerül a projekteredmény-elemek feladatainak meghatározása során, valamint az összeszokottság révén hatékonyabb és hatásosabb munkavégzésre lehetnek képesek.

\subsection{A projektvezetés általános paradigmái}

Megállapítható tehát, hogy a projektmenedzsment igen összetett diszciplína, így az évek során sok általános és széles körben elfogadott nézet merült fel, azonban megfigyelhető több olyan, amely uralkodónak számít. Mivel a projektmenedzsment nem tekinthető érett tudományágnak Kuhn (1984) definíciója szerint, ezért ezen diszciplína esetében a paradigmát nem egységes keretrendszerek jelentik (mint pl. egy időben a matematikában az euklideszi geometria), hanem egy vagy több általánosan elfogadott nézet, amelyet a kutatók többsége egységesen elfogad (vö. Shenhar - Dvir, 2007).

A paradigmák közül kiemelkedik elsőként a projektre irányuló megközelítés, azaz hogy a projektet miként tekintik. Ebben a témakörben három megközelítés uralkodik - ahogy a 2.1-es fejezetben is bemutatása került, nevezetesen a projekt tekinthető (Shenhar - Dvir, 2007):

- egyedi tevékenységnek,

- ideiglenes szervezetnek,

- stratégiai építőelemnek.

Összességében megállapítható tehát, hogy a projekt tekinthető egyszerre folyamatnak, szervezetnek és stratégiai építőelemnek is, ugyanis mindhárom jegyet magán viseli egy projekt. Segíti elérni a stratégiai célt, szervezetként müködik a szervezetben, és a folyamatok jellegzetességeit is magán viseli. A hangsúly minden esetben máson és máson van: a folyamatcentrikus megközelítés esetében a kvantitatív jellemzőkön, a szervezetcentrikus esetében a vezetési megközelítésen, a 
stratégiai megközelítés esetében pedig a vállalati stratégia és a projektek kapcsolatán. Ez természetesen nem azt jelenti, hogy az egyes megközelítések között nem lehetnek átfedések, sőt, hiszen a szervezetcentrikus megközelítés értelmében is szükséges lehet kvantitatív (pl. időtervi ábrázoláshoz köthető) eszközök alkalmazásra, vizsgálatára (vö. 2.5 fejezet).

A második általános paradigma a kétezres évek felé közeledve kezdett általános nézetté válni a projektmenedzsmenten belül, nevezetesen a stratégiai szemléletmód (Görög, 1996). Ma már elengedhetetlenné vált, hogy a projektek menedzselése során a vállalati stratégiával összhangban kerüljenek kialakításra a projektek, és ennek szellemében kerüljenek vezetésre és lezárásra is. Fontos megjegyezni, hogy ez nem feltétlenül esik egybe a korábban meghatározott stratégiai építőkockával, ugyanis ahogy rámutattam, a projektet ilyenkor gyakran egy program részeként kell tekinteni. Ennek a felfogásnak is az alapvető lényegét az jelenti, hogy a célok, célkitüzések meghatározásakor túl kell lépni a projektháromszög alkotta idő, költség, minőség keretén, és a vállalati stratégiát kell kiindulási alapnak tekinteni (akár összehangoltan több projekttel is).

Megállapítható tehát összességében, hogy a projektmenedzsment - bár fiatal tudományág - két alapvető paradigmával rendelkezik, úgymint:

- a projekt alapvető kategóriája,

• a projekt vezetése során a stratégiai szemlélet követése.

Természetesen az imént bemutatott felsorolás nem teljes, hiszen az idők során több nézet is megjelent (pl. hogy a projekt időtartama nem lehet több két évnél [Gareis, 2010b]), azonban ezek nem váltok olyan széles körben, mindenki által elfogadott nézetté, azaz paradigmává, amik egy vizsgálat vagy projektvezetés alapjául szolgálhatnak. 


\section{Projektsiker}

A projektmenedzsment mint diszciplína élete során számos paradigma, definíció és keretrendszer jött létre annak érdekében, hogy képes legyen meghatározni azt, azonban a legfontosabb feladata mindenkor az maradt, hogy a projektet sikerre vigye, és ezek a jelenségek is ennek érdekében lettek megalkotva.

Azonban a projektek menedzselése során sokszor a cég inkább a siker helyett a sikertelenséggel került szembe. A projektmenedzsment hőskorában, a taylori időkben a sikeresség még kiemelkedően magas számot ért el, hiszen minden jól körül volt határolható. A menedzsment egyik legnagyobb feladata az volt, hogy a sokszor képzetlen munkaerőt hatékonyan és hatásosan integrálja a vállalat müködésébe (Apello, 2011). Ez az adott feltételek mellett többé-kevésbé hatékonyan megvalósult. Ennek leképeződései voltak a projektek is, hiszen a munkaerőt projektekbe szervezve megvalósították a kívánt eredményt adott dimenziók mentén.

Azonban a komplexebb tudást igénylő feladatokat már ennyire jól nem lehetett kvantifikálni, és óhatatlanul is megjelent a sikertelenség a projektvezetésben. Ilyenre jó példa az ürkutatás, a haditechnika, a $\mathrm{K}+\mathrm{F}$ vagy szervezetfejlesztési projektek (Görög, 2007). Könnyen belátható, hogy pl. egy ürrepülőgép kifejlesztését jóval nehezebb sikerre vinni, mint egy új gyártósor üzembe helyezését (természetesen feltételezve, hogy mind a két esetben a körülmények megfelelőek a projekt szempontjából). Különösen szembetűnő a klasszikus értelemben vett sikertelenség az informatikai projektekben, ahol a siker esélye a 2000-es évek közepéig 30\% alatt maradt (Deák, 2001), és gyakran volt tapasztalható jelentős költségtúllépés is (Berce, 1998; Radujkovic - Izetbegovic, 2000). Sőt, az ilyen projektek jelentős része, megközelítőleg harmada lett leállítva a projekt befejezése előtt (Lee-Kelley - Long, 2003), azaz kijelenthető, hogy menthetetlenné vált, a vezetőség olyan mértékü költség- vagy időtúllépést látott, amit már nem lehet később helyrehozni, vagy egyéb faktorok sem lettek volna képesek kompenzálni.

Még ennél is szembeötlőbb a sikertelen projektek részaránya a hadseregen belül, ahol a projekteknek csupán 2\%-a volt használva abban a formában, ahogy leszállították (a változással használt projektek száma is mindössze 3\% volt) (Fehér, 2008). Ez azt jelenti, hogy a projektek túlnyomó többsége sikertelenül végződött, azaz rengeteg erőforrás veszett kárba. Ez a tény még akkor is figyelemre méltó, ha 
tisztában vagyunk azzal, hogy a hadsereg sosem volt költséghatékony, és a haditechnika is könnyen idejétmúlttá válhat. Ráadásul egy-egy fejlesztés sokszor nagyon hosszú időt vesz igénybe (elég csak a legújabb gépek kifejlesztésére gondolni, ami sokszor 10 évnél hosszabb időt is igényel annak komplexitása és technológiai bonyolultsága miatt).

Azonban manapság nem csupán a szokványostól eltérő projektekre jellemző a magas sikertelenségi arány. Ugyanúgy tetten érhető az építőiparban vagy akár a nonprofit szektorban is, ahol az állami beruházások sikerességének aránya is igen alacsony (vö. FOVOSZ, 2012).

Ezek alapján megállapítható, hogy a projektsiker mint fogalom elsődleges fontossággal bír a projektvezetés szempontjából, hiszen projektsiker nélkül a vállalatok nem tudják elérni stratégiai céljaikat vagy realizálni bevételeiket. Ráadásul - ahogy a bevezetőben utaltam rá - rendkívül magas összeget költenek rájuk, így a feleslegesen elköltött pénz aránya is aggályos.

Számos kutatás történt már a projektek sikerességét illetően, aminek során különböző megközelítések születtek. Kiemelendő, hogy a sikertelenség csak kevésbé magyarázható az erőforrások hiányával, hiszen manapság ezek már szinte korlátlanul elérhetőek a piacon ${ }^{24}$. Sokkal fontosabb szerepet játszottak az olyan kvalitatatívabb tényezők, mint például az elégtelen projektbehatárolás mértéke, vagy a projektvezetői tudás birtoklásának elégtelen volta (lsd. pl. Standish Group, 2009).

\subsection{A projektsiker értelmezése}

Ahogy korábban utaltam rá, a projektsiker vizsgálata kiemelten fontos. Azonban mit is tekintünk projektsikernek? Mitől tekintjük sikeresnek egy projektet? Hogyan lehet mérni vagy elősegíteni a projekt sikeres teljesülését? Ezen kérdések megválaszolásában nyújtanak segítséget az ún. sikerkritériumok és kritikus sikertényezők. A sikerkritériumok értékelik a projektet sikeresség szempontjából, azaz output oldali megközelítést jelentenek. Definíció szerint a következőképpen hangzik:

\footnotetext{
${ }^{24}$ Kivételt képez természetesen a különlegesen ritka/rendkívül specifikus, helyhez kötött tudás. Ezekért hatalmas verseny folyik szervezetek között és speciális esetekben szervezeten belül egyaránt (vö. Evans, 2000).
} 
„Azok a viszonyítási alapok (normák), amelyekhez mérve értékelhető a projekt sikerességének mértéke" (Görög, 2008, 228. oldal)

A sikerkritériumok ezzel szemben input oldali megközelítést jelentenek, Azaz a kritikus sikertényezők azok, amelynek realizálódása esetén a projektsiker elérésének esélye növekszik, szélsőséges esetben akár 100\%-ra (Fortune-White, 2006; Rockart, 2002).

Ahhoz, hogy a projektsikert maximálisan megismerhessük, szükséges, hogy mind output, mind input oldalról megvizsgáljuk, különben óhatatlanul torz képet kapunk róla.

\subsection{A projektsiker értelmezésének fejlődése}

A projektsiker maximális megértéséhez azonban elengedhetetlen értelmezésbeli fejlődésének ismerete. Ez az evolúció összecseng a projekt és némiképp a stratégia értelmezésének fejlődésével. Judgev és Müller (2005) 4 szakaszt állapított meg munkásságukban ${ }^{25}$.

Az első szakaszba sorolták a klasszikus elméleteket az '50-es évektől a '70-es évek legelejéig ${ }^{26}$, amikor mind a sikertényezők, mind pedig a sikerkritériumok a klasszikus projektháromszög: az idő, költség, minőség paraméterekkel voltak jellemezve (vö. Olsen, 1971). Természetesen ez nem azt jelenti, hogy ez a három jellemző ma ne jelentene fontos szempontot, valamint azt sem, hogy az akkori módszertanok elégtelenek voltak a siker leképezéséhez. Csupán azt jelentette, hogy a piac kiszámíthatósága miatt a hosszú távú stratégiai tervezés tökéletesen elégséges volt ahhoz, hogy a vállalatok megfelelő módon müködhessenek (vö. Antal-Mokos et. al., 2003). Ez magával vonta azt is, hogy a projektek alapvető céljai nem változtak a teljesítés során, azok az értékek maradtak fontosak, amiket a behatárolás során megállapítottak (Judgev-Müller, 2005). Így az időbeli, költségbeli és minőségbeli teljesülés óhatatlanul magával vonta a projekt sikerrel való befejezését.

A második periódus a '70-es és némiképp a '80-as évekre jellemző a és a projektháromszög mint kizárólagos értékelési kritérium elégtelenségét vonta

\footnotetext{
${ }^{25}$ A szerzőpáros amerikai projektek alapján vonta le a konklúziókat. Európában vagy máshol a világon is tetten érhető ez a négy szakasz, azonban az időhorizontja óhatatlanul más a kulturális és egyéb sajátosságoknak köszönhetően.

${ }^{26} \mathrm{Ez}$ nem azt jelenti, hogy korábban ne lettek volna fontosak a projektsiker értékelési tényezői, azonban jelentős szakirodalom a szerzőpáros kutatása szerint nem született.
} 
magával. A két olajválság (amely 1973-ban és 1979-ben következett be) a kiszámíthatatlanságot és a dinamizmust adta „ajándékul” a piacnak (vö. AntalMokos et.al., 2003), és erre a projekteknek is reagálni kellett. Nem volt elég az időbeli, költségbeli és minőségbeli teljesülés, jóval vevőcentrikusabb megközelítésre volt szükség. Ezért egyre inkább előtérbe kerültek olyan sikertényezők és sikerkritériumok, amelyek a vevői és a projekttulajdonosi megelégedettség fontosságát hangsúlyozták (vö. Atkinson, 1999).

A harmadik szakasz a '90-es évekre tehető, ahol a projektre már elengedhetetlenül szükséges volt stratégiai szemmel tekinteni, azaz az eddiginél jóval szorosabb integráció kellett a vállalati stratégiával. Mindez köszönhető volt a világ akkori jellemzőinek (pl. nyitás, egységesedés). Emellett a sikertényezőket nem csak különálló tényezőkként kezelték, hanem keretbe, rendszerbe foglalva, összehangoltan a többi feladattal. Emellett felismerték, hogy már a projektsikerhez nagymértékben hozzájárulnak a külső és belső érintettek (a belső és felvevő szervezet), továbbá a projektet alkotó környezet is markáns szerepet kapott a siker elősegítésében (vö. Belassi - Tukel, 1996; Görög, 2003).

A negyedik periódusban - amely az új millennium sajátja - a stratégiai szemlélet még mélyebb értelmezést kapott, köszönhetően a még gyorsabb és komplexebb világnak (amit pl. a globalizáció vagy akár az internet jelentős mértékű elterjedése okozott (vö. Mészáros, 2010). Ennek következtében az integráltság, az egymásra hatás vizsgálata még inkább szükségszerűvé válik ${ }^{27}$ (vö. Westerveld, 2002).

Ebből is látható, hogy manapság a sikerkritériumok és sikertényezők vizsgálata integráltan, rendszerben kell, hogy megtörténjék, holisztikus szemléletet követve (Turner, 2009), különben óhatatlanul torz képet kapunk a projektről. Ennek köszönhetően pedig akár sikeresnek értékelt projektek végződhetnek bukással vagy épp ellenkezőleg, sikertelennek tartott projektek végződhetnek fényes sikerrel.

\footnotetext{
${ }^{27}$ Szükséges megjegyezni, hogy ennek ellenére viszonylag kevés tanulmány kezelte/kezeli integráltan, rendszerbe foglalva a sikertényezőket, sokkal inkább önállóan, új kritériumot vagy tényezőt igyekeznek meghatározni.
} 


\subsection{A sikerkritériumok}

A projekt sikerkritériumai képezik azt a viszonyítási alapot, amelyek segítségével lehet értékelni a projekteket (Cooke-Davis, 2002; Görög, 2007), azaz eldönteni, hogy sikerrel végződtek-e. Ennek meghatározása sokszor igen komplikált, hiszen egy látszólag jól müködö projekt is komoly bukást eredményezhet hosszabb távon. Azonban meg lehet állapítani, hogy a sikerkritériumok is együtt fejlődtek a projekt értelmezésével (vö. Judgev-Müller, 2005).

Ezek alapján kijelenthető (és ahogy korábban is írtam), a projektsikernek holisztikus szemléletet kell követni, azaz törekedni kell arra, hogy a bevont tényezők köre minél szélesebb legyen, leképezze a mai komplex környezetet.

Az már az 1980-as évek legelejétől egyértelmüvé vált, hogy a projektháromszög önmagában elégtelen a projekt mérésére, szükség volt új megközelítésekre, új tényezőket kellett beemelni a modellbe ahhoz, hogy releváns képet kaphassanak az elemzők.

Számos megközelítés született, és két nagyobb csoport képezhető belölük, úgymint (Görög, 2003):

• egyszintủ megközelítések,

• hierarchikus megközelítések.

Az egyszintü megközelítések lényege, hogy a modellben szereplő értékelési tényezők egyenlő súllyal szerepelnek, míg a hierarchikus modellek - jellegükből fakadóan - eltérő súllyal szerepeltetik a tényezőiket a modellben.

Mindkét megközelítés népszerü a szakirodalomban, azonban Judgev és Müller (2005) alapján két feltételnek meg kell felelnie, úgymint:

- Holisztikusság: szükséges az összes releváns faktor összegyüjtése.

- Realitás: szükséges, hogy a modell alapján történő értékelés megfeleljen a valóságnak, azaz sikeresnek értékelje a valóban sikeres projekteket, és sikertelennek a valóban sikertelen projekteket.

\subsubsection{Az egyszintü megközelítések}

Számos szakirodalmi megközelítés született ebben a témában, mintegy továbbfejlesztve a klasszikus projektháromszög szerinti értékelést. 
Az első fontos kritérium, a releváns faktorok meghatározásában fontos mérföldkőnek számított Wateridge (1997) műve, amely 132 IT/IS projekt alapján gyűjtötte össze az értékelés alapjául szánt kritériumokat. Megállapította, hogy az időbeli teljesülés, a költségbeli teljesülés és a minőségbeli teljesülés mellett három egyéb, rendkívül fontos szempont is szerepet játszik a projektek értékelése során. Ezek a következők:

•Felhasználói igényeknek való megfelelés.

- Az adott cél elérése.

- A végfelhasználók elégedettsége.

A fentiekből megállapítható, hogy ez a modell markánsan figyelembe veszi a megrendelő érdekeit, hiszen a korábban említett három kritérium ennek a leképeződése három különböző aspektus alapján. Ennek fényében kijelenthető, hogy a felhasználói vagy tulajdonosi elégedettség mint értékelési tényező elengedhetetlen, hogy szerepeljen a modellben ${ }^{28}$.

Atkinson (1999) kritériumai már tompítják az IT/IS projektek sajátosságai miatt fellépő végfelhasználói igényeknek való megfelelés túlreprezentálást, noha ő is ilyen típusú projektek alapján állapította meg kritériumait. A szerző - noha a végcélja a siker mérése volt - más irányból kezdte a vizsgálatot, azt nézte, mik okozhatnak sikertelenséget. Ez alapján kétféle típusú hibát különböztetett meg, első típusút és második típusút. Az előbbibe sorolta azokat, amik rosszul, hibásan lettek elvégezve (példaként említette a hibás időtervet vagy költségtervet, de ide tartozik a rosszul becsült kockázatok és a hibásan megtervezett projektkontroll is.). Az utóbbiba, azaz a második típusúba azokat sorolta, amik nem kerültek elvégzésre vagy hiányosan kerültek elvégzésre (ilyen típusú hiba például a hiányos behatárolás, a kockázati tényezők hiányos felsorolása esetleg a hiányos érintett-elemzés). Atkinson (1999) ezekből vezette le, hogy mi alapján lehet mérni a projektsikert. Négy kritériumot fogalmazott meg, úgymint (ld. 6 ábra):

•az idő, költség, minőség hármasa (amit a szerző vas háromszögként emleget, mintegy utalva annak örökérvényüségére),

\footnotetext{
${ }^{28}$ Szükséges ismételten felhívni a figyelmet arra, hogy Wateridge IT/IS projektek alapján vonta le ezeket a következtetéseket, ahol a felhasználói igényeknek való megfelelés kiemelt fontossággal bír (Turner, 2004). Azonban minden projekt esetén szükséges az ezen igényeknek való megfelelés, még akkor is, ha a projekt jellege nem torzítja ennyire efelé az értékelést.
} 
-az információs rendszer (általánosabban fogalmazva a projekteredmény technikai megfelelősége),

- a projekttulajdonosi szervezet számára jelentkező előnyök,

• a többi érintett számára jelentkező előnyök.

\section{6. ábra: A négyzetes út}

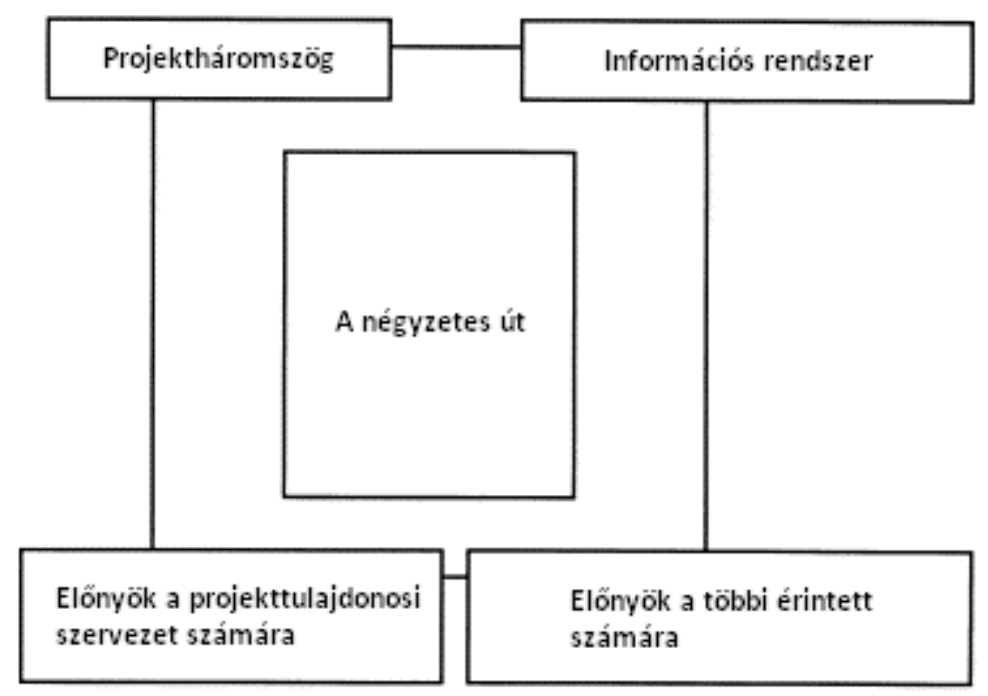

Forrás: Atkinson (1999), 341. oldal

A kritériumok rendkívül hasonlóak a két idézett mü esetében, azonban Atkinson egy új kritériumban tovább lép, nevezetesen az érintettek elégedettségét is beemeli modelljébe. A korábban említett Judgev és Müller (2005) mü alapján kijelenthető, hogy a tágabb értelemben vett érintettek elégedettsége fontos kritériummá vált a projektsiker értékelése során. Így Wateridge kritériumai nem teljesítik az első számú követelményt (a holisztikusságot). Szemben Atkinson modelljével, amely látszólag az összes fontos kritériumot tartalmazza. Ráadásul viszonylag könnyen projektre szabható.

A második feltételt, a realitást is célszerü azonban megvizsgálni. Nevezetesen ha egyenlő súlyúnak veszünk minden kritériumot, akkor reális képet kapunk-e a projekt értékelése során. Ez a kijelentés azonban nem helytálló. Könnyen előfordulhat, hogy az egyik kritérium sérül, mégis sikerrel végződik a projekt (ennek negáltja azonban nem fordulhat elő, azaz ha minden kritérium teljesül, akkor a projekt sikertelenül végzödik, köszönhetően annak a ténynek, hogy maguk az értékelő tényezők holisztikus módon, minden fontosabb tényezőt integrálnak). Elég 
csak az egyik leghíresebb épületre, a Sydney Operaházra gondolni. Maga az épület tervezett átadási ideje az 1963-as tervezett határidőhöz képest 10 évet csúszott, ráadásul a 7 millió ausztrál dolláros kezdetileg előirányzott költség is több mint a tizenháromszorosára emelkedett, és elérte a 100 millió dollárt (Kun, 2005). Azonban vitathatatlanul sikerrel záruló projektről van szó, hiszen ma már Sydney és Ausztrália jelképe, valamint a világ száz csodájának egyike. Ha azonos súlyú kritériumokkal értékelnénk a tényezőket, akkor óhatatlanul hibás képet kapnánk, hiszen Atkinson négy kritériumából hármat ugyan teljesít, egyet azonban megsért. Ez pedig sikertelenséget feltételez. Természetesen lehetne dinamikusabban kezelni a modellt, és feltételezni, hogy a másik három kompenzálhatja ennek a hiányosságát, azaz elég csupán három kritérium teljesülése a négyböl. Azonban ez már azt jelentené, hogy nem egyenlő mértékben tekintjük fontosnak a kritériumokat.

Ezek alapján pedig leszürhető, hogy vannak olyan kritériumok, amelyek „kompenzálhatják” egyik-másik hiányos teljesülését. Ez pedig óhatatlanul a hierarchikus modellek szükségességét indukálja.

A Sydney Operaház példája (és a következtetések) felvetik a korlátozott racionalitás (vö. Simon, 1957; 1982) problémáját, hiszen látható, hogy nem a legjobb kimenet valósult meg, mégis sikeresnek lett értékelve. Azaz a döntéshozók elfogadták a kielégítő eredményt, nem az optimális elérését tartották egyetlen elfogadhatónak. Ez két dolognak tudható be. Egyfelöl betudható annak, hogy a környezeti feltételek túl komplexek voltak ahhoz, hogy megfelelően felmérjék, és ezért a döntési folyamatot egyszerüsítették (vö. korlátozott racionalitás). Így az esetleges változási igények nem szerepeltek az előzetes várakozásokban (vö. Kun, 2005). Másfelől betudható annak, hogy az értékelési kritériumok megfelelő súlyozása nem valósult meg, holott ez szükséges lett volna (vö. Tofallis, 2012). Utóbbira nyújthat támpontot a KIPA-módszer (Kindler - Papp, 1984), amely a komplex döntések esetében használható különösen jól. A módszer egyik eleme az értékelési kritériumok súlyozása.

Belátható, hogy a súlyozás mindenképpen szükséges (vö. Tofallis, 2012), még akkor is érdemes így tenni, ha a korlátozott racionalitás értelmében nem lehet maximális pontosságú súlyrendszert kialakítani. Ez pedig a hierarchikus modellek használatának szükségességét indokolja (részletesebben ld. 3.3.2. fejezet). 


\subsubsection{Pénzügyi alapú értékelési modellek}

Szükséges megjegyezni, hogy néhány mü ettől eltérő, pénzügy alapú értékelési modellt tart megfelelőnek (pl. Freeman - Beale, 1992; Gardiner - Stewart, 2000; Yu et al, 2005). Azaz nem vevői/végfelhasználói elégedettség vagy időbeli teljesülés alapján értékel, hanem olyan, a vállalati életben széles körben használt és ismert mutatószámok alapján, mint például a ROI vagy az NPV.

Azonban ennek is megvannak a maga korlátai. Egy olyan projekt esetén, amely profitorientált vagy vállalati költségekhez jól köthető célból lett életre hívva (például egy lakópark építése vagy költségracionalizálás részlegek egybeolvasztása révén) életképesnek tünhet. Azonban az értékelés nem mutat túl a projektet megelőző pénzügyi megvalósíthatósági tanulmány ex post és ex ante összehasonlításán. Ráadásul a puhább tényezők értékelését nem teszi lehetővé (például a projektvezetés minőségét elkendőzi ez a fajta értékelés). A komolyabb korlátot mégsem ez jelenti, hanem azok a projektek, amelyek pénzügyi szempontból kevéssé vagy egyáltalán nem mérhető projektek. Ilyenre példa lehet egy tudásmenedzsment rendszer bevezetése. Könnyen belátható (különösen az utóbbi esetben), hogy az ilyen típusú projektek hasznát egyáltalán nem vagy csak súlyos egyszerüsítések árán lehet mérni.

Ezt a hiányosságot próbálták többen feloldani a vállalati életből ismert Balance Scorecard módszer projektre történő átültetésével (pl. Eilat et al, 2008), azonban a korábban említett fő hiányossága itt is megmutatkozik, nevezetesen túlzott hangsúlyt kapnak a kvantitatív szempontok. A nehezen számszerüsíthető eredményekre ez a fajta értékelés is érzékeny. Továbbá súlyozás híján - projekttől függően - egyes értékelési tényezők túl nagy, míg mások túl kevés fontossággal kerülnek figyelembevételre. Természetesen ezt lehetne kompenzálni megfelelő súlyok beiktatásával ezáltal alakítva hierarchikus megközelítéssé (vö. Tofallis, 2012). Azonban meg kell állapítani, hogy a Balanced Scorecardon alapuló értékelési módszer mindenképp túlmutat a tisztán pénzügyi értékeléseken, lévén több szempontot integrál. Hátránya nem is az értékelési kritériumok hiányában (bár némiképp abban is), hanem a súlyozás hiányában mutatkozik meg (vö. Eilat et al., 2008). 
Ezek alapján kijelenthető, hogy a pénzügyi alapú értékelési modellek sem alkalmasak a projektek széles körü, pontos értékeléséhez, ráadásul ezek a modellek a holisztikusságot mint elengedhetetlen jellemzőt sem teljesítik.

\subsubsection{Kulcsfontosságú teljesítménymutatók (KPI-k)}

Az egyszintü megközelítések csoportjába tartoznak továbbá az ún. kulcsfontosságú teljesítménymutatók (Toor - Ogunlana, 2010), amelyek bizonyos mutatószámok alapján értékelik a projektet ${ }^{29}$, és ezek alapján döntenek a projekt sikerességéről. A KPI-kkel történő értékelés során meghatározzák az ezekhez a mutatószámokhoz tartozó minimálisan elvárt értékeket (normákat), aminek el kell érni, különben a teljesítmény nem megfelelő, azaz a projekt nem végződik sikerrel. Ilyen lehet például egy informatikai rendszer esetében a válaszadás sebessége vagy az egyszerre lebonyolítható tranzakciók száma. Természetesen ennél kvalitatívabb megközelítések is lehetségesek.

Könnyen belátható, hogy ezek a mutatószámok nagyon hasonlóak a korábban említettekhez, és jelentős hátránya a nehezen kvantifikálható projektek esetén mutatkozik meg. Akkor, amikor mutatószámokat nem vagy nehezen lehet hozzárendelni a projektekhez.

Ezen kívül megjelenhetnek még a jól kvantifikálható projektek esetén is olyan puhább tényezők, amelyek teljesülése szintén fontos, de a KPI-kkel nem lehet kifejezni.

Továbbá az egyes mutatószámokat ez a módszer is egyenrangúként kezeli, azaz nem rendel súlyokat az egyes értékekhez, ami szintén magában rejti azt a veszélyt, hogy a projektsikerről alkotott képe nem lesz reális.

Ezek alapján kijelenthető tehát, hogy a KPI alapon történő értékelés sok esetben hasznos lehet, és ráirányítja a figyelmet a projekt rendkívül fontos kvantitatív paramétereire, aminek elérésére az esély - a módszer sajátja miatt jelentősen megnő. Azonban komoly hiányosságokat is tartalmazhat az értékelés (holisztikusság, realitás hiánya), így egy projekt sikerének meghatározására célszerü lehet a KPI-knél átfogóbb megközelítéseket használni.

\footnotetext{
${ }^{29}$ Ez az értékelési rendszer is elsősorban a vállalati teljesítmények definiálására/meghatározására használatos, azonban felhasználták projektek értékelésére is.
} 


\subsubsection{3 Összegzés}

Természetesen az imént leírt értékelési módszerek nem minden esetben alkalmatlanok a projektek sikerességének elbírálására, sok vállalat használja ezeket. Söt, bizonyos esetekben az atkinsoni „,vas háromszög” is tökéletesen elégséges a siker megállapításához. Azonban komoly korlátokkal rendelkeznek, hiszen sok olyan projekt van, ahol nem használhatóak, lévén nem elégítik holisztikus és/vagy racionalitás feltételét. Ezért szükségesek a hierarchikus megközelítések.

\subsubsection{Hierarchikus megközelítések}

A hierarchikus megközelítések már kijavítják Atkinson modelljének prioritásból fakadó hibáját, hiszen „rangsorolják” a sikerkritériumokat. Ebből fakadóan a legfőbb kérdést az jelenti, hogy hány lépcsőfokra van szükség ahhoz, hogy a lehető legpontosabban megfeleljen a valóságnak ${ }^{30}$.

De Wit 1988-as munkásságában két szintet különböztet meg, úgymint a projekt projektháromszög (projektvezetés) szerinti sikeressége és a projekt sikeressége, amely az érintettek elégedettségét jelenti. Ezeket hierarchikusan, egymástól elkülönülten kezeli. További előnye a modellnek, hogy kölcsönösséget feltételez a két lépcsőfok között, azaz a projektháromszög sikeressége segítheti a másik lépcsőfok szerinti sikeresség elérését. Azonban megjegyzi, hogy fordítva már nincs így. Ez viszont nem minden esetben felel meg a valóságnak (elég csak a korábban említett Sydney Operaház példájára gondolni). A kérdés továbbra is az, hogy a két lépcsőfok elég-e a valóság leképezésére.

Baccarini (1999) ehhez hasonló kritériumrendszert állapított meg. Ugyanúgy két lépcsőfokban határozta meg a sikeres projekt követelményeit, úgymint:

- termék szerinti sikeresség,

- projektvezetés szerinti sikeresség.

Az utóbbi a projektvezetés hatékonyságát értékeli, miszerint adott időre, adott költségen és adott minőségben képes volt-e leszállítani a terméket. Tehát ez az értékelési rendszer sem nélkülözi a vas háromszöget.

\footnotetext{
${ }^{30}$ Nem minden esetben beszélnek a szerzők hierarchikus megközelítésröl. Azonban én azokat vettem ilyen típusú modellnek, ahol a müből világosan kiderül, hogy nem egyenlö súllyal veszi figyelembe az egyes kritériumokat.
} 
A termék szerinti sikeresség azonban túllép ezen, és további három szempont szerint értékel, úgymint:

- a projekttulajdonosi szervezet stratégiai célkitüzéseinek való megfelelés (projekt alapvető célja),

- a felhasználói igényeknek való megfelelés (projekt célja),

-az érintettek azon érdekeinek való megfelelés, amely kapcsolódik a projekteredményhez.

Látható, hogy Baccarini modellje megfelel az elvárásoknak (csakúgy, mint de Wité), azaz minden lényeges, releváns szempontot mérlegel. Külön kiemelendő, hogy a stratégiai célkitüzésnek való megfelelés is bekerült az értékelési kritériumok közé, ez pedig tovább erősíti relevanciáját, hiszen Judgev és Müller (2005) megállapította, hogy az új millenium turbulens környezetében óhatatlanul szükség van a stratégiai szemlélet követésére. További előnye Baccarini müvének, hogy felhívja a figyelmet a kölcsönhatásra a két lépcsőfok között, azaz a projektvezetés hatékonysága óhatatlanul hatással van a termék szerinti sikerességre, hiszen a stratégiai célt nagymértékben befolyásolja a projekt időtartama vagy költsége. Természetesen a hatás visszafelé is igaz, a termék szerinti sikeresség mintegy utólag igazolhatja az esetleges időbeli vagy költségbeli túllépést (és bizonyos esetekben a minőségbeli problémákat is). A szerző megemlíti továbbá, hogy az egyes kritériumok értékelésének időhorizontja eltérő, hiszen míg a projektháromszög szerinti értékelést rögtön a projekt lezárása után meg lehet tenni (sőt, a projektkontroll elemeit felhasználva, folyamatosan nyomon lehet követni és szélsőséges esetben be is lehet avatkozni, visszaterelve a megfelelő teljesítési mederbe), addig a termék szerinti sikerességet csak a projekt lezárását követő időszakban tudjuk értékelni. Ezen időkülönbség természetesen projektenként eltér. Ebből fakadóan a projekt értékelése nem ér véget, nem érhet véget a projekt használatba vételével, szükséges időről időre utóértékelni.

A modell látszólag tehát holisztikus, és jól rávilágít az összefüggésekre az egyes dimenziók között, azonban egy nagy hiányossága továbbra is adódik. Nevezetesen a termék szerinti sikeresség egyes dimenzióit továbbra is egyenrangúként kezeli, holott könnyen belátható, hogy ez nem minden esetben van így. Például egy ERP rendszer esetében hiába teljesült időben, költségben és adott paraméterek mellett a projekteredmény, hiába lenne képes mindenben megfelelni a 
vezetők elvárásainak, ha a végfelhasználók nem tudják használni a rendszert, óhatatlanul sikertelenségre van ítélve ${ }^{31}$. Szélsőségesebb példa egy környezetre markáns hatást gyakorló projekt, például egy atomreaktor építése, ahol a környező érintettek vagy bizonyos csoportosulások (pl. Green Peace) meggátolhatják a projekt sikeres befejezését és lezárását (sőt, sok esetben az elkezdését is), még akkor is, ha ezen szélsőséges csoportok elégedetlenségét leszámítva mindenben megfelelő lett volna a projekt.

Ebből fakadóan a két hierarchiaszint nem elégséges a megfelelő értékeléshez, szükséges olyan megközelítést alkalmazni, amely az érintettek elégedettségét és a projekttulajdonosi szervezet (vagy projekttulajdonos) elégedettségét nem kezeli azonos súllyal.

Erre kínál megoldást a hierarchikus modell (Görög, 2007), amely három szinten vizsgálja a projekt sikerességét, úgymint:

- A projekt időtartama, költsége és minőségbeli megfelelősége.

- A projekttulajdonos elégedettsége (azaz a projekt mennyiben járult hozzá a projekt alapjául szolgáló stratégiához).

- Az érintettek elégedettsége (azaz a többi, a projekt szempontjából releváns érdekcsoportok projekthez füződő érdeke/érdekei milyen mértékben teljesült/teljesültek).

Ezt a 7. ábra szemlélteti.

\footnotetext{
${ }^{31}$ Ilyenkor felmerülhet a kérdés, hogy ebben az esetben valóban teljesül-e a projekttulajdonosi szervezet stratégiai céljainak való megfelelés, azaz ha a végfelhasználók, akik a rendszer alapját képezik, nem képesek használni, nem jöhet létre például hatékonyságnövekedés. Ez azonban már csupán következménye annak, hogy a végfelhasználói elégedettség nem volt meg.
} 


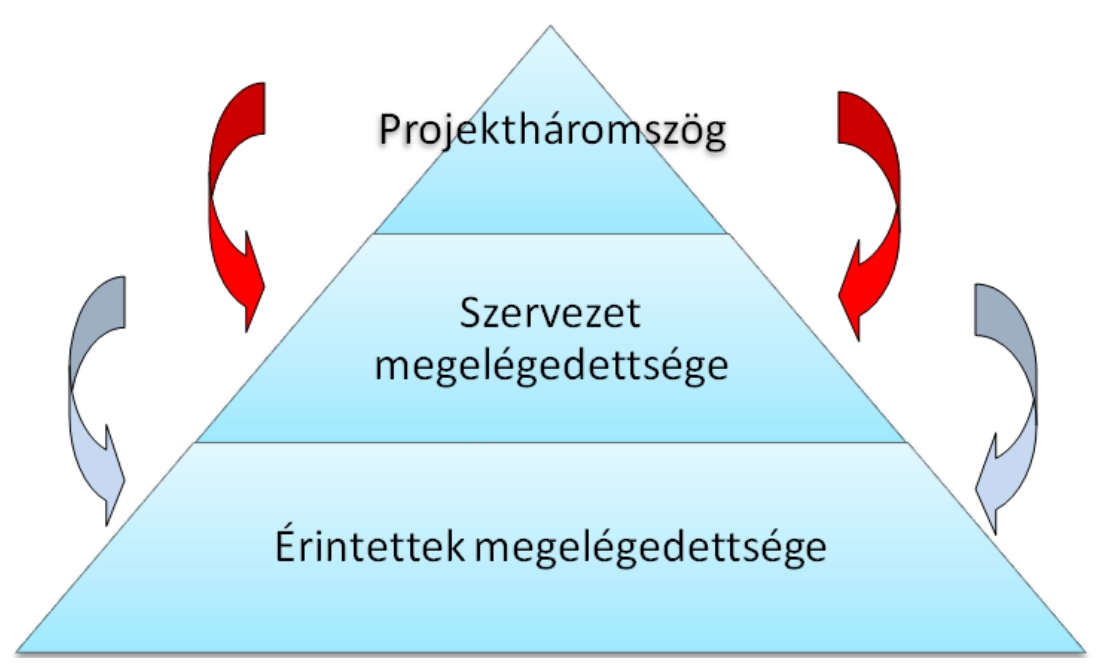

Forrás: Görög (2007) alapján saját szerkesztés

Korábban megfogalmazásra került, hogy a modellben található három kritérium szerint szükséges értékelni a projektet. Azaz értékel hatékonyság (projektháromszög) és hatásosság (projekttulajdonos és érintettek elégedettsége) alapján is. Így megállapítható, hogy a hierarchikus modell kielégíti a holisztikusság feltételét. A modell a másik feltételnek is megfelel a kölcsönhatások, szintek és (ennek révén a súlyok) figyelembevételével Emellett a projekt magában foglalja a stratégiai szemlélet, amelyet Belassi és Tukel (1996), Grundy (1998), Judgev és Müller (2005) kiemelt (méghozzá a második és bizonyos mértékig harmadik kritérium által). Ennek fényében megállapítható, hogy a projekt magába foglalja a korábban bemutatott modellek minden elönyét, relevanciában viszont mindenképpen túllép rajtuk.

A szerző kiemeli továbbá, hogy az egyes kritériumok között kölcsönhatás áll fenn. Azaz, ahogy Baccarini (1999) is megállapította az időbeli, költségbeli és minőségbeli teljesülés óhatatlanul hatással van a projekttulajdonos elégedettségére, és ennek teljesülése némiképp kompenzálhatja a túllépéseket. Azonban a projekttulajdonos elégedettsége is hatással lehet az érintettek elégedettségére, illetve a fordított reláció is fennáll. Az elégedett érintettek (pl. a végfelhasználók egy tudásmenedzsment rendszer esetében) hatással lehetnek a projekttulajdonosok elégedettségére. 


\subsection{3 Összefoglalás}

Ezek alapján megállapítható tehát, hogy a hierarchikus modell teljesíti mindkét fontosabb feltételt, azaz holisztikus szemlélete révén az összes fontos sikerkritériumot magában foglalja, valamint a realitás is biztosítva van a szintek bevezetése által. További nagy előnye, hogy a stratégiai szemlélet is tükröződik benne (méghozzá a második és bizonyos mértékig harmadik kritérium szerint), ez pedig tovább növeli a modell relevanciáját. Enélkül ugyanis nehézségekbe ütközne a projekteket a mai, kiszámíthatatlan környezetben értékelni. Azaz megadja a szükséges dinamizmust. Kijelenthető tehát, hogy amennyiben valós képet akarunk kapni a projektekről, célszerü eszerint a modell szerint értékelni.

Fontos megjegyezni újra, hogy előfordulhatnak olyan helyzetek, amikor nem szükséges eszerint a modell szerint értékelni, bármely más modell is releváns képet adhat a projekt sikeréről. Akár a pénzügyi megközelítésű modellek, akár a nem hierarchikusak, akár a kétlépcsősök, sőt, szélsőséges esetben a projektháromszög is elégséges lehet. Ráadásul a stratégiai cél teljesülését és az érintettek elégedettségét csak a projekt teljesítése után mérhetjük le, azaz az értékelésnek túl kell mutatnia a projekt időhorizontján. Ez természetesen erőforrást (időt, embert) igénylő feladat, azonban a tapasztalatok és az esetleges „korrigáló projektek” szempontjából kiemelten fontos.

Szükséges megemlíteni, hogy a korábban említetteken túl egyéb szerzők is foglalkoznak a sikerkritériumokkal (1sd. pl. Agarwal - Rathod, 2006; Ahadzie et al, 2008; Bryde - Robinson, 2005; Doloi, Iyer - Sawhney, 2011; Gemünden et al, 1990, Hassen et al, 2011; Laubschagne - Brent, 2005; Lim - Mohamed, 1999; Patanakul Milosevic, 2009; Project Management Institute, 2008; Savolainen et al, 2012; Thomas - Fernandez, 2008; Worthen 2008). Azonban ezek a szerzők vagy hasonló szempontok szerint értékelnek, vagy kevesebb kritériumot vesznek figyelembe vagy a tanulságaik összegezve lettek a korábban említett néhány munkában.

Ezek alapján kijelenthető, hogy a hierarchikus modell megfelel a 3.3-as fejezetben említett két feltételnek (holisztikusság, realitás). Emellett a stratégiai szemléletmódot is integrálja magába, aminek szükségességét több szerző (pl. Grundy, 1998) is kiemelt. Így a modell kiváló alapot képez a projektsiker megfelelő értékeléséhez. 


\subsection{Kritikus sikertényezők}

Ahhoz, hogy teljes képet kapjunk a projektsikerről, célszerü input oldalról is megvizsgálni. Erre kínálnak megoldást a sikertényezők vagy még inkább a kritikus sikertényezők. A kettő között a különbséget a mérték jelenti. Míg a sikertényezők elősegíthetik a sikert, addig a kritikus sikertényezők (KST-k) nagymértékben (vagy a projekt szempontjából a legnagyobb mértékben, szélsőséges esetben akár 100\%-ban is) járulnak hozzá a projektsiker eléréséhez (Rockart, 2002).

Ezen jellemző képezte a kritikus sikertényezők módszerének alapját. Ennek a módszernek a lényege, hogy a projekt kialakítása során meg kell határozni kevés számú (lehetőleg 3-7) tényezőt, amelyeknek elérése már önmagában biztosíthatja a projekt sikerességét (lsd. pl. Earl, 1989). A kritikus sikertényezők módszerének virágkora a 90-es évekre tehető, azonban ez nem azt jelenti, hogy manapság nem találkoznák KST-k meghatározásával. Azonban a gyakorlat ma már inkább támpontként használja, semmint erre építi a projektvezetés folyamatát (vö. Görög, 2008), ugyanis annak ellenére, hogy önmagukban nem biztosítják a sikert, nagymértékben hozzájárulnak annak eléréséhez, így a kulcstényezők megtalálása óhatatlanul kedvező hatással bír a projekt sikerességét illetően.

\subsubsection{A kritikus sikertényezők fejlődése}

Ahogy a sikerkritériumok, úgy a kritikus sikertényezők „fejlődése” is megegyezik a projekt értelmezésének fejlődésével. Kezdetben a KST-k a projektháromszögre koncentrálnak, ennek biztosítását látták elsődlegesen szükségesnek ahhoz, hogy egy-egy projekt sikerrel végzödjön. Azonban a hosszútávú stratégiai tervezés bukásával szükséges volt, hogy megjelenjenek „szoftabb”, menedzsmenthez kötődő tényezők is (vö. Antal-Mokos et. al.). Ilyen például a projektvezetők vagy projektcsapat kompetenciája, de lehetne említeni például a felsővezetői támogatás meglétét is (vö. Fortune - White, 2006; Judgev Müller, 2005).

Fortune és White (2006) 63, a témával foglalkozó szakirodalmat vizsgált meg, és ez alapján azonosított több tucat kritikus sikertényezőt. Azonban kiszürve a redundanciát, azaz a tartalmi egyezőséget és a megfogalmazásbeli különbséget, ez a szám 27-re csökkent. Szükséges ugyanakkor megjegyezni, hogy néhol túlzott 
mértékű egyszerüsítéssel éltek, ugyanis a felsővezetői támogatás és a felsővezetői bevonás nem feltétlen esik egybe. Ezek alapján a következő öt sikertényező volt a legnépszerübb:

- felsővezetői támogatás (39 helyen fordult elő a 63-ból),

- $\quad$ tiszta, világos célok (31 helyen fordult elő a 63-ból),

- jól felépített/részletes terv naprakészen tartva (29 helyen fordult elő a 63-ból),

- jó kommunikáció/visszajelzés (27 helyen fordult elö a 63-ból),

- felhasználó/kliens részvétel (24 helyen fordul elő a 63-ból).

Összességében meg lehet állapítani, hogy a hangsúly ma már inkább a szoftabb tényezőkön van, kevéssé kapcsolódnak a projektháromszöghöz, mint a projektvezetés évtizedekkel korábbi koncepcióinál. Ráadásul további eredmény, hogy a projekt és a szervezet kapcsolata egyre hangsúlyosabbá válik (felsővezetői támogatás, pontos projektcélok, felhasználói részvétel).

Érdekes megközelítést jelent Turner (2004) négy pontja, amely összegzi két szerző kritikus sikertényezőkről és sikerkritériumokról szóló értékezését. A négy pont a következö:

- A sikerkritériumokban az érintettekkel már a projekt kezdete előtt meg kell állapodni.

- A projekttulajdonos (vagy szponzor) és projektmenedzser között együttmüködő munkaviszonyt kell fenntartani, és a projektet mint társulást kell tekinteni.

- A projektmenedzsernek meg kell hagyni a megfelelő rugalmasságot, de a projekttulajdonosnak folyamatosan irányvonalat kell mutatni, azaz definiálni, merre haladjon a projekt.

- A tulajdonosnak folyamatos figyelemmel kell kísérnie a projektet teljesítmény szempontjából.

Látható (és erre Turner is felhívta a figyelmet), hogy ezek a pontok nem valódi sikertényezők, hiszen teljesülésük még nem feltétlen eredményezi a projektek sikerességét. Sokkal inkább sikertelenségi tényezők, azaz amennyiben nem 
realizálódnak, akkor a projektsiker elérésének esélye csökken ${ }^{32}$. Látható, hogy ezek a tényezők is inkább a projektmenedzser illetve a projektszervezet fontosságát hangsúlyozzák. Hiszen az első pont lényegét tekintve megegyezik az érintettek bevonásával (a projekthez köthető magasabb szintü tervezés egy részének kialakításába), ami által elkerülhetővé válik, hogy a fontosabb érintettek ne fogadják el a végterméket (pl. a végfelhasználók egy ERP rendszer esetén). A második pont a kooperatív munkavégzést igyekszik hangsúlyozni a két legmarkánsabb szereplő, a projektvezető és a projekttulajdonos között. Ennek hiányában ugyanis felmerülhetnek autoritásbeli kérdések, amelyek óhatatlanul nehezíthetik a munkát, és a projekt sikertelenségével végződnek. A harmadik pont kapcsolható kissé az előzőhöz, bár szükségszerúen más szemszögből közelíti meg. Eszerint szükség van irányelvekre, de amennyiben azok nagymértékben korlátozzák a projektmenedzsert, akkor nem képes a megfelelő mértékben reagálni a változásokra (az irányelvek aktualizálása nélkül). Márpedig - ha nem kiugróan rövid projektről van szó változásokkal mindig kell számolni. Utolsó pontja az állandó kontroll fontosságát hangsúlyozza, amely nélkül a projektben az esetleges hibákra nehezen/későn/nem megfelelő módon lehetne csak reagálni.

Összességében megállapítható tehát, hogy a fentebb említett négy pont más oldalról közelíti meg a projektsiker kérdését, hiszen sikertelenségi kritériumokat határoz meg (ld. még pl. Al-Ahmad et. al., 2009; Kappelman et. al., 2006)). Azonban ez csak látszólagos ellentmondás a korábban bemutatottakkal, hiszen ugyanúgy a projekt sikerének esélyét növeli az a tevékenység, ha a sikertelenségi tényezők elkerülésére erőforrást áldozunk.

Természetesen ennél sokkal több mü szól a kritikus sikertényezőkről, azonban ezek nagy száma (mind a műveké, mind a faktoroké) behatárolják az átfogóbb vizsgálat lehetőségét. Ezért célszerü csoportosítani őket. A szakirodalom alapján kilenc nagyobb csoportot lehet elkülöníteni. A csoportosítás alapját Görög(2007) csoportosítása jelentette, azonban ez kiegészítve lett Fortune-White(2006) és számos cikk (Black, Akintoye - Fitzgerald, 2000; Bryde, 2008; Chen - Chen, 2007; Cheung, Yiu - Chiu, 2009; Clark (1998); de Bakker, Boonstra - Wortmann, 2010; Fiedler, 2010; Fortuna - White, 2005; Gelbard - Carmelli, 2009; Ho, Chang - Wang, 2008; Hartman - Ashrafi (2002); Hormozi - Dube (1999), Jang - Lee, 1998; Lindner -

\footnotetext{
${ }^{32}$ Azonban ezek egyidejü teljesülése mégis nagymértékben növeli a projektsiker esélyét.
} 
Wald, 2011; Müller - Turner, 2010; Ng - Tang, 2010; Papke-Shield, Beise - Quan, 2010; Pinto - Kharb-a (1996); Pinto - Slevin, 1987; Turner, 2004; Umble, Haft Umble. 2003; Yang, Huang - Wu, 2011; Yeo (2002); Yu - Kwon, 2011; Westerveld, 2003) sikertényezőivel. A kilenc tényezőcsoport a következő:

- a projekteredmény tartalmi behatárolásának mértéke és ezen behatárolás pontossága,

- folyamatos kommunikáció a projektcsapaton belül, valamint a projektcsoport és a projekt érintettjei között (ebbe a kategóriába tartozik a végfelhasználói részvétel és a felsővezetői támogatás is),

- a projekttel elérendő stratégiai cél egyértelmüsége és a terv erősségének mértéke,

•az idő-, erőforrás- és költségtervezés realitásának mértéke, ennek kontrollja és az erőforrások rendelkezésre állása,

- a projektvezető kompetenciái és a (vezetési) stílusa,

- a projektcsapat felkészültsége és motiváltsága,

- a kockázatok értékelése és ezek kezelési módja,

- a változásokra történő felkészülés és a változások kezelésének módja,

• szervezeti és környezeti jellemzők.

Mint látható, ezek a kategóriák is igen összetettek, sok tényezőt foglalhatnak magukba. Azonban a további vizsgálatok elvégzéséhez ez megfelel, hiszen rávilágít a fontosabb csoportokra. Ráadásul ezen vizsgálatok céljából szükség volt a kategorizálásra és ezek a csoportok jól leképezik a legtöbb eddig ismert sikertényezőt.

Összességében megállapítható tehát, hogy a kritikus sikertényezők mind száma, mind pedig spektruma igen kiterjedt. Ebből fakadóan szükség volt létrehozni olyan csoportokat, amik a vizsgálatot megkönnyíthetik. Természetesen ez nem azt jelenti, hogy mindegyik sikertényezö-csoportot meg kell vizsgálni, csupán azt, hogy célszerü figyelemmel lenni azok eltérő voltára az elemzések során.

\subsubsection{A kritikus sikertényezőket ért kritikák}

A KST-k és föként a KST-k módszere rendkívül sok kritikát kapott az évek során, hiszen néhány tényezőbe süríteni a projektsiker elérésének módját nehéz 
feladatnak tünik. Azonban nem is feltétlen ez okozta a legnagyobb problémát a szakembereknek, sokkal inkább két jellemző, amelyet Fortune és White (2006) összegzett:

- A kritikus sikertényezők fontossága időben nem állandó, így a változás mértékét és időbeliségét is szükséges lenne elemezni, azonban erre a vizsgálatok már nem terjednek ki.

-A sikertényezők közötti kapcsolatot a szakirodalom nem elemzi, holott a tényezők közötti kapcsolat fontosabb lehet, mint maga a faktor.

A második pontra a szerzőpáros a következő példát hozza. A felsővezetői támogatás olyan tényező, amely a szervezethez kapcsolódik, és befolyásolja a gazdaság állapota. A projekttevékenységek egyedisége hatással lehet a projektmenedzser kompetenciájára. A felsővezetés támogatásának hiánya együtt a projektmenedzser kompetenciájának hiányával viszont könnyen vezet a sikertelenséghez.

A két kritikát ki lehetne egészíteni még további kettővel. Az első, hogy a vizsgálatok túlnyomó többsége a projektsikert osztatlan fogalomként kezeli, azaz nem veszi figyelembe a sikerkritériumokat. Ez némiképp egybecseng az első kritikával, hiszen amennyiben a projektsikert homogén jelenségként kezelik, akkor a fontossága az egyes tényezőknek nagy mértékben változik a projektteljesítés során. Viszont amennyiben a projektsikert megbontják különböző kritériumokra, az időbeliség változása okozta prioritásbeli különbségeket némiképp lehet tompítani. A második, hogy általános, általános érvényü kritikus sikertényező azonosítása nehézségekbe ütközhet (Görög, 2008).

Fortune és White (2006) által összegyüjtött második kritika a korrelációk fontosságát hangsúlyozza, azonban - megítélésem szerint - önmagában is hasznos információk születhetnek, ha a tényezőket önmagukban elemezzük, hatással a sikertényezőkre. Hiszen a KST-k hatásának kimutatása az adott sikerkritériumra az első lépés, ennek mértékének meghatározása újabb vizsgálatok szükségességét teszi lehetővé.

Összefoglalva, a KST-ket ért kritikák relevánsak, szükséges, hogy a projektsikerre ne csak homogén formában tekintsünk. Ráadásul a korrelációk 
figyelembe vételével javítható a KST-k módszere is, hiszen a köztük lévő kapcsolat jelentős befolyással lehet a tényező teljesülésének mértékére.

\subsubsection{A kritikus sikertényezőket ért kritikákra adott válaszok}

A kritikus sikertényezőket ért kritikák - mint ahogy korábban bemutatásra került - jelentősen korlátozhatják maguknak a tényezőknek a használhatóságát. Azon munkák száma viszonylag kevés, amely figyelembe veszi a négy kritika bármelyikét vagy mindegyikét - összehasonlítva a kritikus sikertényezőkkel foglalkozó szakirodalom számához képest (vö. Fortune - White, 2006). Így kevés tanulmány születet, amely a kritikus sikertényező (pl. a projektvezető irányítási módja) hatását vizsgálja a projektsiker bizonyos aspektusaira (1d. pl. Jha - Iyer, 2007), és ennél is kevesebb szentel figyelmet a tényezők közötti korreláció vizsgálatára (ilyenre kivétel pl. Yang, L. , Huang, C. - Wu, K., 2011). Ezek közül a kutatások közül kiemelkedik Cserháti és Szabó (2014) munkája, amely a sikerkritériumokra (a projekt céljainak teljesülése és a projekt érintettjeinek elégedettsége) gyakorolt hatását vizsgálja a kritikus sikertényezőknek (projekt tartalmi-terjedelmi behatárolása, szerződéses feltételek, projekt vezetése, a szervezeti kultúra, kommunikáció és együttmüködés a beszállítókkal és szponzorral, partnerség kialakítása a helyi érintettekkel). Előnye, hogy rendkívül részletes és kellő megalapozottsággal teszi mindezt, nem csupán 1-1 kritériumot vagy faktort vesz elemzése középpontjába.

Továbbá született két olyan megközelítés, amely keretbe próbálja foglalni a tényezőket és a sikerkritériumokat.

\subsubsection{A Project Excellence Model@ alapján történő összehangolás}

Egyiket Westerveld (2003) mutatta be és Project Excellence Model@ alapján. Elönye a kutatásnak, hogy az EFQM (European Foundation of Quality Management) modelljét használja fel és ezt egészíti ki az azóta kiadott fontosabb szakirodalommal. A modell alapját az adja, hogy a szervezeti jellemzők összehangolásra kerülnek a projekt céljával (lsd. 8. ábra). 


\section{8. ábra: A Project Excellence $\operatorname{Model}{ }^{\circledR}$}

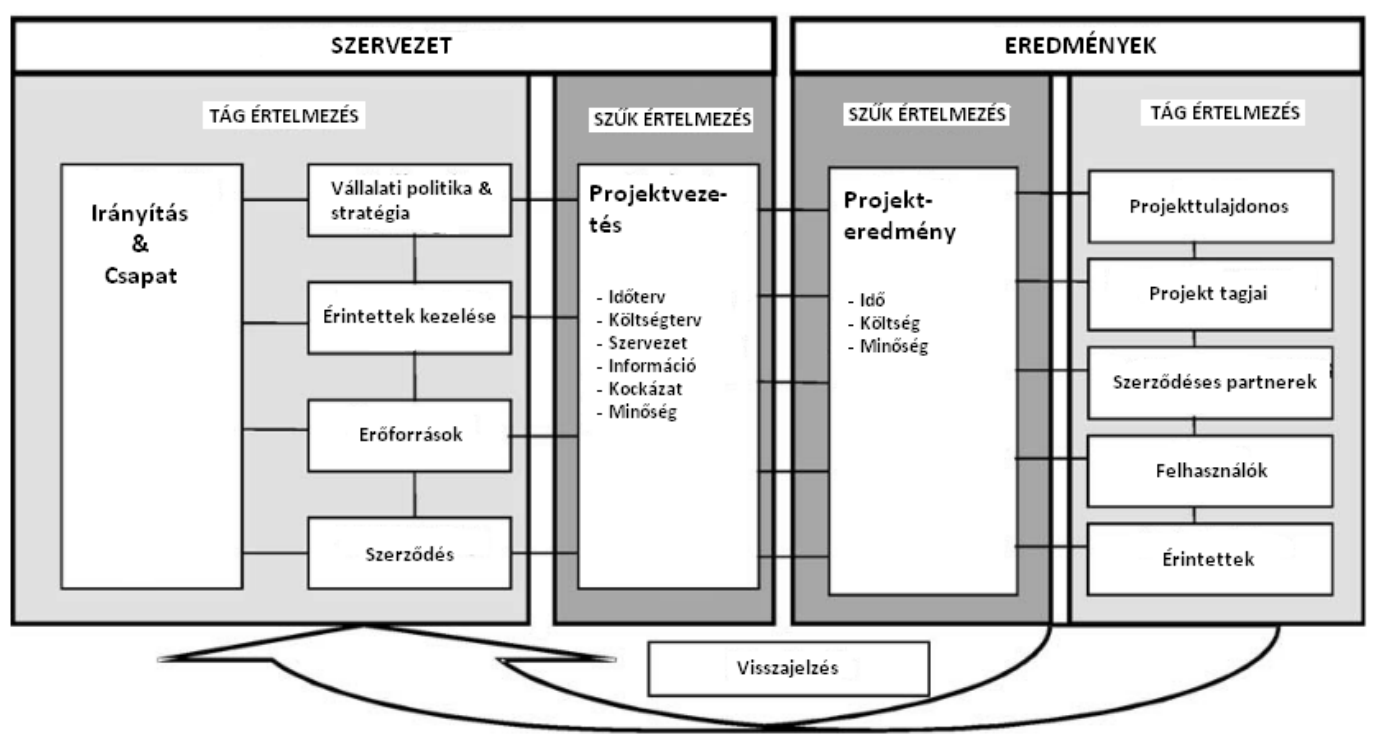

Forrás: Westerveld (2003), 415. oldal

A modellből világosan kitünik, hogy 6 szempont szerint értékel, úgymint:

- a projekt szükebb értelmezése (idő, költség, minőség),

- a projekttulajdonos szempontja szerint,

- a projekt tagjai szerint,

- a projekt szerződéses partnerei szerint,

- a projekt felhasználói szerint,

- a projekt tágabb értelemben vett érintettjei szerint.

Könnyen belátható, hogy az itt felsorolt kritériumok megfelelnek a holisztikusság kritériumának (vö. Judgev-Müller, 2005, Turner, 2009), azaz értékel a projektháromszög, a projekttulajdonos és a tágabb értelemben vett érintettek elégedettsége alapján. Egyetlen hátránya, hogy nem hierarchikus módon értékel. Azonban ennek súlyosságát némiképp tompítja, hogy a modell immanens sajátossága révén azonosíthatunk tágabb és szükebb értékelési kritériumokat, amik megfelelő környezetbe helyezve akár a hierarchikusságot is jelenthetik.

A modell az értékelési kritériumok mellett azonosít olyan tényezőket, amelyek elősegíthetik ezeknek a teljesülését, elsősorban vállalati szempontok szerint vizsgálja, és a következőket sorolja fel: 
- a projektvezető vezetési stílusa (különös tekintettel a projektcsapat kezelésére),

- a projekt alapjául szolgáló stratégiai cél megfelelősége (és ennek egyértelmüsége),

- az érintettek hatékony felhasználása,

- az elérhető erőforrások megszerzése és rendelkezésre állása,

- a megfelelő szerződéses feltételek kialakítása és a megfelelő partnerek kiválasztása,

- a projektkontroll milyensége.

A szerző megállapítja, hogy nem minden típusú projekt igényel minden fajta értékelési szempontot (pl. belső projektek esetén a projektekkel szerződésben álló érintettek elégedettsége értelemszerüen nem releváns), sőt, nem minden esetben van szükség az összes szervezeti „segítségre”.

Ebből fakadóan Westerveld (2002) szükségesnek tartja a projekt megfelelő kategorizálást is mint „nulladik kritikus sikertényezőt”. Ennek fényében öt különböző projekttípust azonosít, úgymint:

- Termékorientált: ilyenkor a projekt egy olyan szervezet, amelynek célja olyan termék létrehozása vagy megváltoztatása, amit a tulajdonos definiál. Példának hozta egy kórházi fényvédő berendezés lecserélését.

-Eszközorientált: a projektet ebben az esetben olyan folyamatnak tekinti, amelynek szintén egy végtermék megalkotása a cél, de ez esetben speciális eszközöket és módszertanokat kell használni. Példának hozta egy gyár speciális karbantartását.

- Rendszerorientált: A projekt egy rendszer, amelynek célja egy olyan termék megalkotása, amelynek behatárolása során több felhasználó és érintett érdekét figyelembe kell venni. Példának hozta a szerző egy olyan iskola átadását, amelyet a helyi közösség (gyermekek és szüleik) igénye hívott életre.

- Stratégiaorientált: A projekt egy szervezet, aminek a célja egy olyan projekteredmény létrehozása, amely megfelel a vevő és a felhasználók elvárásainak, miközben külső érintettek általi kötöttségek befolyásolják. Egy ERP rendszer bevezetése tipikusan ebbe a kategóriába sorolható. 
- Totális projektmenedzsment: A projekt ebben az esetben már olyan komplex rendszer, amit az érintettek kapcsolata is markánsan meghatároz, és célja a felhasználók vagy tulajdonos igényeinek kielégítése. Példaként lehetne említeni a szerző szerint egy városközpont felújítását.

Természetesen eltérő projekttípusokhoz eltérő értékelési szempontok és eltérő sikertényezők tartoznak. Az alábbi táblázatban Westerveld (2002) összegzi ezeket:

\section{4. táblázat: A projekttípusok jellemzői a Project Excellence Model® szerint}

\begin{tabular}{|c|c|c|c|c|c|}
\hline & $\begin{array}{c}\text { Kulcsszavak a szervezet } \\
\text { esetében }\end{array}$ & Kulcs eredmény területek & $\begin{array}{l}\text { Kulcs vállalati } \\
\text { terület }\end{array}$ & Kulcs a sikerhez & $\begin{array}{c}\text { Kulcs kontrol } \\
\text { területek }\end{array}$ \\
\hline Termékorientált & $\begin{array}{l}\text { Egyszerü hierarchikus irányitás } \\
\text { Világos munkaköri leírás } \\
\text { Elörehaladási jelentések } \\
\text { Hatékonyság } \\
\text { Tevékenységek kivitelezése }\end{array}$ & Projekteredmények & Projektvezetés & Opportunizmus & Idő és költség \\
\hline Eszközorientált & $\begin{array}{l}\text { A feladatok megosztása } \\
\text { Támogató eszközök } \\
\text { Szakaszos kivitelezés } \\
\text { Hatékonyság } \\
\text { Reagálás a konfliktusra }\end{array}$ & $\begin{array}{l}\text { Projekteredmények } \\
\text { A projekt tagjainak } \\
\text { értékelése }\end{array}$ & Erőforrások & $\begin{array}{l}\text { Az erőforrások } \\
\text { hatékony } \\
\text { felhasználása }\end{array}$ & Idő és költség \\
\hline Rendszerorientált & $\begin{array}{l}\text { Érintettel irányítása } \\
\text { Érintettek informálása } \\
\text { Együttműködés a szerződéses } \\
\text { partnerekkel } \\
\text { A munkafolyamat minősége } \\
\text { A kockázatok becslése és } \\
\text { kezelése }\end{array}$ & $\begin{array}{l}\text { Projekteredmények } \\
\text { A projekt tagjainak } \\
\text { elismerése } \\
\text { A szerződéses partnerek } \\
\text { elismerése }\end{array}$ & Szerződések & $\begin{array}{l}\text { A környezet } \\
\text { helyes } \\
\text { feltérképezése }\end{array}$ & $\begin{array}{l}\text { Idő, költség, } \\
\text { minőség, } \\
\text { kockázatok }\end{array}$ \\
\hline Stratégiaorientált & $\begin{array}{l}\text { Vevő alapú interakció } \\
\text { Konzultáció a vevővel és } \\
\text { felhasználóval } \\
\text { A vevői és felhasználhalói } \\
\text { igények támogatása } \\
\text { Flexibilitás } \\
\text { Proaktív kockázatmenedzsment }\end{array}$ & $\begin{array}{l}\text { Projekteredmények } \\
\text { A projekt tagjainak } \\
\text { elismerése } \\
\text { A szerződéses partnerek } \\
\text { elismerése } \\
\text { A vevő elismerése } \\
\text { A felhasználók elismerése }\end{array}$ & $\begin{array}{l}\text { Vállalati } \\
\text { politika és } \\
\text { stratégia }\end{array}$ & Rugalmasság & $\begin{array}{l}\text { Idő, költség, } \\
\text { minőség, } \\
\text { kockázatok, } \\
\text { szervezet }\end{array}$ \\
\hline Teljes projektmenedzsment & $\begin{array}{l}\text { Felelősség megosztása } \\
\text { Kooperáció a döntéshozatal és } \\
\text { kivitelezés során } \\
\text { Hosszútávú megoldás } \\
\text { Innovatív megoldások } \\
\text { Kockázatok közös } \\
\text { menedzsmentje }\end{array}$ & $\begin{array}{l}\text { Projekteredmények } \\
\text { A projekt tagjainak } \\
\text { elismerése } \\
\text { A szerződéses partnerek } \\
\text { elismerése } \\
\text { A vevő elismerése } \\
\text { A felhasználók elismerése } \\
\text { Az érintettek elismerése }\end{array}$ & $\begin{array}{l}\text { Érintettek } \\
\text { kezelése }\end{array}$ & $\begin{array}{l}\text { Konszenzus } \\
\text { kialakítása }\end{array}$ & $\begin{array}{l}\text { Idő, költség, } \\
\text { minőség, } \\
\text { kockázatok, } \\
\text { szervezet, } \\
\text { információ }\end{array}$ \\
\hline
\end{tabular}

\section{Forrás: Westerveld (2003), 416. oldal}

A táblázatból világosan kitünik, hogy a rendszer önmagában komplex és megfelel a holisztikusság nyújtotta kritériumoknak (vö. Judgev-Müller, 2005, Turner, 2009). Viszont arra a kérdésre nem tud választ adni ${ }^{33}$, hogy milyen sikertényezők mely sikerkritériumokat befolyásolják. Csupán indirekt módon lehet rá következtetni, azaz ott, ahol csupán egy értékelési kritérium szerepel, mindegyik

\footnotetext{
${ }^{33}$ A szerző ezt nem is tűzte ki célul.
} 
arra van hatással. De természetesen ahol már több van, ott nem lehet ezt megmondani.

Ezek alapján kijelenthető, hogy bár a modell hatalmas elörelépés, hiszen integráltan, rendszerbe foglalva kezeli a sikertényezőket és sikerkritériumokat, ráadásul gyakorlati relevanciájához nem férhet kétség, azonban a hierarchikusság hiánya és a specifikáció gátat szab annak, hogy általános vizsgálat alapjául használni lehessen. Természetesen ez nem jelenti azt, hogy gyakorló szakemberek számára ne jelentene értékes tudást.

Szükséges megemlíteni, hogy a Project Excellence Model ${ }^{\circledR}$ újabb változata már kidolgozásra került (ld. International Project Management Association, 2014), megváltozott tartalommal, azonban megörizve alapvető jellegét és struktúráját. Azonban Westerveld (2003) a korábbi változatra vetítve vonja le következtetéseit, így ezért az került bemutatásra.

\subsubsection{A Formal System Model}

A másik ismert megközelítés, amely igyekszik rendszerbe foglalni a sikerkritériumokat és a sikertényezőket a Fortune és White (2006) szerzőpároshoz köthetö. A modell alapját a Formal System Model képezi, amelyet Bignell és Fortune (1984) fejlesztett ki a projekt sikertelenségére adott válaszként.

A modell legnagyobb előnye, hogy összehangoltan kezeli az értékelési kritériumokat és az ezt elősegítő tényezőket (lsd. 6. ábra). 


\section{9. ábra: A Formal System Model}

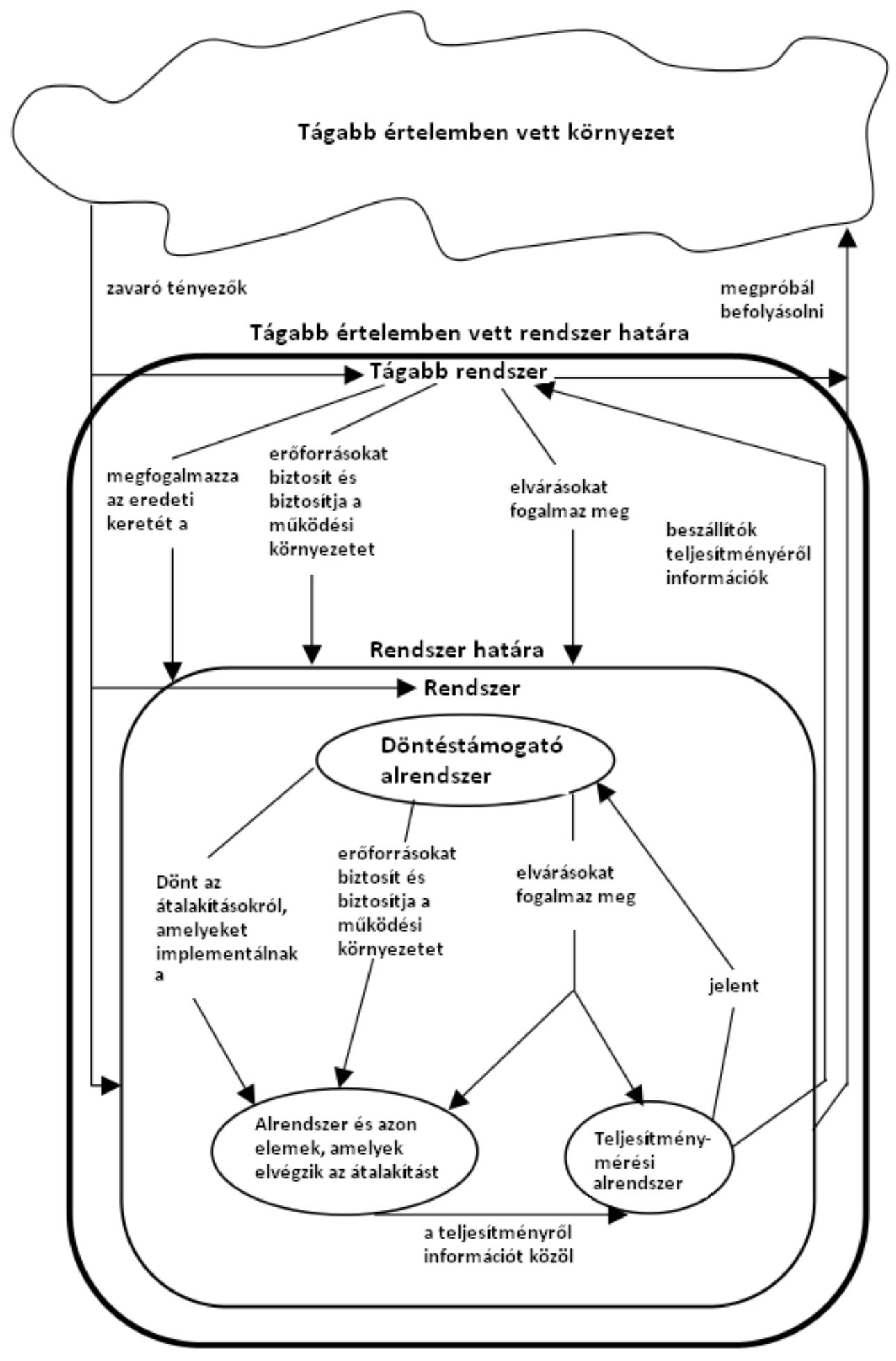

Forrás: Fortune - White (2006), 57. oldal

A modell alapvetően három nagyobb részre osztja a projekt környezetét, amely az értékelési kritériumoknak is megfelel, úgymint:

• szükebb értelemben vett rendszer, 
- tágabb értelemben vett rendszer,

- tágabb értelemben vett környezet.

A szükebb értelemben vett rendszer hivatott a projektvezetést reprezentálni. Ennek alapján megtalálhatóak benne azok a sikerkritériumok és sikertényezők, amelyek ehhez a dimenzióhoz kapcsolódnak (a szerző gyüjtése alapján). Ilyen például a klasszikus projektháromszög szerinti értékelés vagy az erőforrások rendelkezésre állása és a folyamatos kommunikáció ${ }^{34}$. Emellett nagyon fontos szerepet tölt be a teljesítményértékelési rendszer, amelynek feladata részben megfelel a hagyományos értelemben vett kontrollnak, azaz az időbeli, minőségbeli és költségbeli teljesítmény értékelése, valamint szükség esetén a tervektől való eltérés jelentése. Azonban ezen túlmegy, hiszen a kockázatok és változások kezelését is ez az alrendszer hivatott megoldani. Természetesen ezt szükséges még projektre szabni, azaz létrehozni a projektcsapatot, aminek feladata a projekt megvalósítása, egy monitor rendszert (vagy személyt kinevezni), aminek (akinek) feladata a kontroll és a folyamatos visszajelzés. Emellett szükséges egy projektmenedzser is, aki megteremti a mikrokörnyezetet, amiben lehetséges megvalósítani a projektet (időterv, költségterv, a szükséges változtatások implementálása és a módszerek - ha szükséges - definiálása).

A második „lépcsőfokot” a tágabb értelemben vett rendszer jelenti, amely a projekttulajdonosi szervezet elvárásait és lehetőségeit hivatott reprezentálni. Ennek a résznek (pontosabban a projekttulajdonosi szervezet képviselőjének/képviselőinek, mint pl. a projektszponzornak vagy a Projekt Irányító Bizottságnak), a fő feladata definiálni az elvárásokat és az erőforrások rendelkezésre állását biztosítani. Természetesen a folyamatos kommunikáció is szükséges ahhoz, hogy a projekt sikerrel végződjön. Emellett a kontrolljelentéseket és a változásokra történő reagálást is folyamatosan monitoroznia kell, valamint ezeket értékelni, és amennyiben szükséges, akkor a javító intézkedéseket illetően további elvárásokat megfogalmazni.

Harmadik, és egyben utolsó alrendszer a tágabb értelemben vett környezet, amely egyaránt tartalmaz passzív és kevésbé passzív elemeket is. Itt olyan környezeti szereplőkre kell gondolni, mint a jogszabály alkotói, a tanácsadók vagy akár a beszállítók. Ezek a szereplők óhatatlanul hatással vannak a projektre, miközben a

${ }^{34}$ Az első a felsorolásból sikerkritérium, míg az utóbbi kettő sikertényező. 
projekt eredménye vagy remélt eredménye (illetve ennek lehetősége) is hatással lehet rájuk. Azaz a külső környezet feltételeket szab (még akkor is, ha indirekten, mint pl. a tanácsadók kapacitása és szaktudása) a projekt teljesítését illetően, míg kis mértékben alakulhat hozzáállásuk, elvárásuk (pl. a beszállítók attitüdje változhat).

Összességében megállapítható tehát, hogy a Formal System Model komplex rendszer, amely összehangolni hivatott a kritikus sikertényezőket a sikerkritériumokkal. A szerzőpáros gyakorlati példán keresztül bemutatja, hogy miként képes kezelni ez a rendszer egy bonyolultabb, komplexebb projektet (mindkét projekt esetében körülbelül 120 érintettel lehetett számolni). Kijelentik végül, hogy sikerült összehangolni a teljesítést a teljesítmény értékelésével.

\subsubsection{Az összehangolást ért kritikák}

A szakirodalomra épülő összehangolások legnagyobb hátránya, hogy nagyon specifikusan igyekeznek megteremteni az összhangot a két sikerhez köthető mutatószám között. Ilyen például, hogy a vezetési stílus miként befolyásolhatja az érintettek elégedettségét. Mindenképpen pozitívum, hogy a sikert már nem homogén fogalomnak tekintik, hanem igyekeznek a modern kritériumoknak megfelelő módon, több részre osztani azt (pl. Yang, L. , Huang, C. - Wu, K., 2011). Természetesen erre ellenpéldát is találhatunk, ahol a projektsiker továbbra homogén fogalomként van kezelve (pl. Bryde, D.J., 2008). Így ki lehet jelenteni, hogy ezek azok az úttörők, amelyekre a későbbiekben lehet építeni, azonban spektrumuk túl szük ahhoz, hogy egy kutatás során komolyabb alapot képezzenek. Azonban mindenképpen pozitívum, hogy a többi vizsgálat legnagyobb hibáit kiküszöböli ezáltal demonstrálva azt, hogy a kevésbé általános, jóval specifikusabb, de ebből fakadóan jóval szükebb eredményt biztosító vizsgálatoknak is van létjogosultsága (vö. Cserháti - Szabó, 2014).

A másik megoldás, amikor keretrendszert próbálnak megalkotni a projektek menedzselésére. Két példát mutattam be, az egyik a Project Excellence Model ${ }^{\circledR}$, a másik pedig a Formal System Model volt.

Az elöbbi legnagyobb hátránya, hogy nem derül ki egyértelmüen, milyen sikertényezők mely’ sikerkritériumok teljesülésére vannak hatással (vö. Cserháti Szabó, 2014; Jha - Iyer, 2007). Azonban előnynek tekinthetjük, hogy integráltan, rendszerszemléletet követve elemzi a projekt környezetét. Összességében úgy vélem, hogy a modell rendkívül jó megközelítés, azonban relevanciáját tovább lehetne 
emelni, ha az egyes tényezők hatását részletesebben megvizsgálnák. Továbbá nem azonosítható egyértelműen, hogy milyen tényezők képesek kompenzálni egy másik tényező gyengeségét, vagy mely’ tényezők elengedhetetlenek minden esetben.

A másik megközelítést a Formal System Model jelentette. Ebben az modellben a legnagyobb gondot az értékelési kritériumok direkt megjelenésének hiánya okozza. Hasonló a helyzet, mint a másik modell esetében a sikertényezőkkel. Csupán következtetni lehet, hogy mik fontosak az adott érintetteknek. Ráadásul az egymásrahatásokat a modell csak indirekten veszi figyelembe, hiszen pl. a felhasználók elégedettsége komoly ráhatással bírhat a projekt sikerességére, pl. egy ERP rendszer esetében. Ez viszont a Formal System Modelből nem tünik ki, „csupán” indirekten lehet következtetni.

Így az egyik modell a másik hibáját küszöböli ki, annak erősségének negligálása által. Azaz nem valósul meg egyszerre világosan a sikertényezők és sikerkritériumok direkt összehangolása.

\section{5 Összefoglalás}

A fejezetből megállapítható, hogy mind a kritikus sikertényezők, mind pedig a sikerkritériumok sokat fejlődtek az elmúlt évtizedekben, és kijelenthető, hogy az új millennium olyan változásokat hozott, amikre a szakirodalomnak is reagálnia kellett. A sikerkritériumok tökéletesen megfeleltek az új kor várakozásainak, a hierarchikus modellek (különösen a három lépcsőfok szerint értékelö) képesek reagálni a dinamikus, komplex feltételekre. A kritikus sikertényezőket azonban még mindig érhetik jogos kritikák, hiszen a szerzők többsége még mindig arra összpontosít, hogy meghatározzák azokat a faktorokat, amik a legnagyobb mértékben hozzájárultak a sikerhez. Azonban ezen már mindenképpen szükséges túllépni, különben túl specifikus, kevéssé használható kritériumok születhetnek (vö. Görög, 2007). Ezt kiküszöbölendő megjelentek már vizsgálatok, amelyek a három fő kritikát (időbeli állandóság, egymásrahatás hiánya és a projekt mint homogén jellemző) igyekeztek kijavítani. Azonban ezek közül csak néhány kezdeményezés vette ezeket figyelembe maximálisan. Azok a megközelítések, amelyek igyekeztek az összes kritikát figyelembe venni (ami óhatatlanul azt jelenti, hogy egynél több sikertényezőt vizsgáltak), sajnos nem adtak választ az összes hiányosságokra. A két általam bemutatott a Formal System Model és a Project Excellence Model ${ }^{\circledR}$. Ebben a két 
megközelítésben továbbra sem lehet egyértelműen azonosítani, hogy mely’ sikertényező mely’ sikerkritériumra hat. Ennek fényében pedig kétségessé válhat a faktorok egymásra hatásának értelmezése (ami a sikert hivatott elérni) és az időbeli változás fontosságára is.

Mindezek alapján kijelenthető tehát, hogy manapság, ha valaki a kritikus sikertényezők projektre gyakorolt hatását akarja vizsgálni (és releváns következtetéseket levonni), nem tudja elkerülni, hogy a projektsikert ne a hierarchikus megközelítések egyike szerint vizsgálja (méghozzá célszerü a háromlépcsős, hierarchikus modellt alkalmazni). Ez már önmagában is elősegíti, hogy az időhorizont miatt jelentkező prioritásbeli különbséget figyelembe vegyék (erre azonban célszerü további figyelmet szentelni). Továbbá, amennyiben nem egy tényezőről van szó, akkor óhatatlanul figyelembe kell venni a tényezők közötti kölcsönhatást is. Így összességében olyan kutatási modellt célszerü felállítani, amely hierarchikus modell szerint vizsgálja a projektsikert, és ennek rendeli alá a KST-t vagy KST-ket. 


\section{A projektvezetői kompetenciák}

A projektek legfontosabb részét tulajdonképpen maguk az emberek képezik, a siker egyik legfőbb zálogai, hiszen hiába áll kétszer annyi erőforrás rendelkezésre, mint amennyivel kényelmesen sikerre lehet vinni egy projektet, ha alkalmatlan csapat kezeli, óhatatlanul kudarccal fog végződni, míg egy alkalmas projektcsapat és projektvezető némiképp tudja kompenzálni az erőforrásból eredő hiányokat (v.ö. Fortune - White, 2006; Standish Group, 2009). Ebből fakadóan az őket irányító projektmenedzser fontossága elvitathatatlan. Könnyen belátható tehát, hogy a projektmenedzser az egyik legjelentősebb, a sikerre egyik legnagyobb mértékben hatást gyakorló szereplője a projektnek (vö. Fortune - White, 2006). Így számos ismerettel és készséggel, azaz kompetenciával kell rendelkeznie. A projektvezetési kompetenciára mint kritikus sikertényező fontosságára több szerző is felhívta a figyelmet (ld. pl. Ahadzie 2014; El-Sabaa 2001; Lampel 2001; Loo 2002). Fortune és White (2006) cikke alapján a témával foglalkozó kutatók több mint 30\%-a tartotta kiemelten fontosnak a projekt sikeres teljesülése szempontjából a kompetens projektvezetőt $\mathrm{t}^{35}$.

A projektvezetői kompetenciák értelmezésének elméleti alapját az általános kompetenciaértelmezések jelentik. Sokan minden személyhez kapcsolódó attribútumot, mint pl. a személyiségjegyeket, tulajdonságokat, tudást vagy motivációt magába foglaló jellemzőnek tartják a kompetenciát (ld. pl. Boyatzis, 1982; Winterton et. al., 2006). A projektvezetési szakirodalomban is hasonló felfogással találkozhatunk, azaz projektvezető személyiségjegyeit, tulajdonságait, motivációját, tudását és képességeit is beleértik a kompetenciába (vö. Ahadzie et. al., 2009; Briére et. al., 2014; Chen et. al., 2009, Spencer - Spencer, 1993; Stevenson Starkweather, 2009).

Disszertációmban a kompetenciák közül a projektvezető képességei, vezetési stílusa és a személyiségjegyei kerülnek vizsgálatra, hiszen a fogalom önmagában túl tág lenne ahhoz, hogy minden egyes területe részletesen megvizsgálásra kerülhessen.

\footnotetext{
${ }^{35}$ A legmagasabb értéket, majd 62\%-ot a felsővezetői támogatás érte el. Magát a projektvezetői kompetenciát (pontosabban a kompetens projektmenedzsert) a 6. legfontosabbnak tartották a szakírók Fortune - White (2006) cikke szerint.
} 


\subsection{A projektvezetői képességek}

Projektvezetői képességek alatt azokat a tudásterületeket érthetjük, amiket a projektvezetőnek birtokolnia kell ahhoz, hogy sikeresen vezesse a projektet (Görög, 2013a). A projektvezetői képességek, azaz a projektvezető tudása vagy szemléletmódja összetett kritikus sikertényező, hiszen számos részterületből tevődik össze.

Azonban szükséges felhívni a figyelmet arra a tényre, hogy a képesség mint fogalom igen tág témakör, több elemet rejt magában, és a megfelelő képességekkel rendelkező projektvezető kifejezés óhatatlanul mást jelenthetett az '50-es években, mint manapság ${ }^{36}$, így áttekintésük és összegzésük indokolt.

\subsubsection{A projektvezetői képességek fejlődése}

A projektvezetői képességek tartalmának fejlődése összhangban áll a projekt és a projektsiker értelmezésének fejlődésével (vö. Görög, 2003).

A kezdeti megközelítések főként a projektháromszög behatárolásának és biztosításának fontosságát taglalták. Ez abból fakad, hogy a kezdeti megközelítések során a projektet mint egyedi feladatot értelmezték, azaz a projektvezető feladata a projekt folyamatának vezetése volt. Fontosnak ítélték a klasszikusnak számító projektvezetési ismeretek birtoklását (pl. időterv megtervezése), és az ezt segítő technikai ismereteket (pl. az egy építkezési projekt esetén az egy tevékenységek alapvetői technikai tartalmának ismeretét) (vö. Olsen, 1971). Azaz a projektvezető által birtokolt tudásterületek során a szerzők a kvantitatív technikákat helyezték a középpontba.

Azonban a sikertelenül végződő projektek magas száma, az egyre dinamikusabbá váló projektkörnyezet és ebből fakadóan a projekt és a projektvezetés értelmezésének fejlődése óhatatlanul szükségessé tette ennek a bipoláris értelmezésnek a kiszélesedését. Emellett többen a projektvezető vállalati és egyéb korlátaira is, és az érintettek növekvő fontosságára is felhívták a figyelmet (pl. Pinto, 2000, Zimmerer - Yasin, 1998), úgymint:

\footnotetext{
${ }^{36}$ Különösképpen az olyan projektmenedzsment módszerek fényében, mint pl. az agilis megközelítés, ahol a projektvezető irányítói feladata jóval kevésbé hangsúlyos, mint a tradicionális megközelítések esetén (ld. 2.6. fejezet).
} 
- Egyre nagyobb mértékben járulnak hozzá a sikertelenséghez a projektcsapathoz köthető problémák, és ezzel összefüggésben, a projektsikerben nagy szerepet játszottak az érintettek megfelelő menedzselésére irányuló technikák.

-A projektvezető személyes jellemzői szintén nagy szerepet játszanak a projektsiker elérésében (pl. problémamegoldó képesség vagy eredményorientált, proaktív viselkedés).

- A projektvezetők általában nem a hierarchia magas fokáról érkeznek a projektekbe, így a vállalati hierarchia által biztosított hatáskörük sokszor nem elégséges a projektcsapat hatékony menedzseléséhez.

Az utolsó pont magában foglalja ugyanakkor azt is, hogy sokszor a projektvezetőnek nincsen formálisan biztosított hatásköre pl. a jutalmazáshoz, ami igen komoly motiváló tényező lehet egy projekttag esetében. Ha figyelembe vesszük azt, hogy a projektcsapat tagjai egyre markánsabb szerepet játszanak a projektsiker elérésében (vö. Fortune - White, 2006; Görög, 2003), akkor könnyen belátható, hogy a projektmenedzsereknek más eszközökhöz kell folyamodni, ha a maximális teljesítmény nyújtására akarják sarkallni őket, és ebből fakadóan maximalizálni a projekt sikerességét.

Ez összhangban áll a projekt és a projektvezetés értelmezésének fejlődésével, hiszen Lundin és Söderlund (1995) rámutatott arra, hogy a projektre nem lehet csupán egyedi feladatra tekinteni, hanem szükséges ideiglenes szervezetként is definiálni. Ebből fakadóan a projektvezető szerepe is kibővül, azaz vezetnie kell ezt az ideiglenes szervezetet. Ehhez pedig óhatatlanul szükség van olyan ismeretekre, képességekre, amelyek az ideiglenes szervezet vezetését segíti elő, azaz emberhez kötődő, humán képességekre.

Ebből fakadóan a projektcsapat menedzselésére irányuló képességek mint a projektvezetői tudás elemei igen fontossá váltak. Azonban a többi képesség megléte sem elhanyagolható fontosságú, így ki lehet jelenteni, hogy a technikai és a klasszikus kvantitatív projektvezetési képességek mellett a humán képességek is fontos szerepet kaptak.

Több szerző is igyekezett a '90-es évek végén, a 2000-es évek elején összegezni, hogy milyen tudásra van szüksége a projektmenedzsernek (pl. Edum- 
Fotwe - McCaffer, 2000; El-Sabaa, 2001; Loo, 2002). Ezek alapján meg lehet állapítani, hogy alapvetően két kérdéskört tartottak fontosnak, úgymint:

- Technikai képességek: ez magában foglalja a projekt szakmai tartalmának ismeretét (tágabb értelemben véve is, mint például az adott projekteredményhez köthető pénzügyi paraméterek ismeretét is).

-Humán képességek: a projekt érintettjeinek menedzseléséhez szükséges ismereteket foglalja magában. Egyes szerzők tovább bontják ezt pl. vezetési ismeretekre, szervezési ismeretekre (pl. Loo, 2002), motivációs és kommunikációs képességekre (El-Sabaa, 2001; Henderson, 2004; Pinto, 2000; Sotiriou - Wittmer, 2001), azonban ezek jellegükben nem térnek el az alapvető céljától ennek a képességterületnek, azaz az érintettek kezelésétől.

Összességében megállapítható tehát, hogy a '90-es évek végére, 2000-es évek elejére egyértelművé vált, hogy pusztán technikai ismeretekkel rendelkező projektmenedzser esetén jelentősen csökken a projektsiker esélye. Azonban ez nem azt jelenti, hogy elhanyagolhatóak az ilyen jellegü ismerek (elég csak az 2.1 fejezetben bemutatott projekttermékekre megalkotására gondolni). Viszont a humán képességek is igen fontos elemét képezik már a projektvezetés eszköztárának, sőt, bizonyos szerzők szerint még a technikai képességeknél is fontosabbak.

Ezzel párhuzamosan Cleland (1994) felhívta a figyelmet arra, hogy a projektek stratégiai építőelemek is, azaz a projektvezetés egyik feladata a projekt által létrejövő kedvező változás leszállítása. Ez pedig elengedhetetlenné tette, hogy a technikai és humán képességek mellett a projektvezető olyan eszköztárral bírjon, amely elősegíti ennek a kedvező változásnak a menedzselését.

Így megállapítható, hogy manapság a projektvezetési tudás eszköztárát három dimenzió szerint célszerű felépíteni, úgymint (Cleland, 1994; Dogbegah et. al., 2011; Hwang - Ng, 2012):

- technikai képességek,

• humán képességek,

- projektvezetési specifikusképességek.

Az első csoportba, azaz a technikai képességek közé sorolhatók továbbra is a projekt szakmai tudását jelentő területek, úgymint a projekt szakmai tartalmának 
ismeretét vagy azokat a gazdasági ismereteket, amelyek elengedhetetlenek a projekt tervezése és kivitelezése során.

A második csoport, az a humán képességek továbbra is azokat a tudásterületeket foglalják magukban, amelyek az érintettek vezetéséhez/befolyásolásához kapcsolódnak. Ez a képesség is jellegéből fakadóan összetett, több tényezőből tevődik össze (Clements - Gido, 2006; Görög, 2003; Mantel et. al., 2001).

Harmadik kategóriába, azaz a projektképességek közé a projektvezetési eszköztár ismerete és alkalmazása sorolható, karöltve a projektmenedzser szemléletmódjával. (Cleland, 1994; Görög, 2008). Szükséges megjegyezni egyfelől azt, hogy ezen jellemzők egy részét korábban is fontosnak találták (ld. pl. Zimmerer - Yasin, 1998), azonban ennyire élesen nem különítették el, egyéb képességek részeként tekintették őket. Másrészt pedig azt, hogy ez a képességkategória már túlmutat a klasszikus képességértelmezéseken (különösen a szemléletmód), hiszen már nem csak tudásterületeket, hanem a tudás alkalmazását, a projekthez való viszonyulást is magában foglalja. Egyesek külön kompetenciaként értelmezik (ld. pl. Ahadzie et. al., 2009; Görög, 2013a; Spencer - Spencer, 1993).

\subsubsection{A projektvezetési specifikus képességek szintjei}

Ahogy az előző fejezetben bemutatásra került, mindegyik képesség összetett, mélyebb bemutatásra azonban csak az utóbbi kerül, összhangban a disszertáció céljával. Projektképességeknek tekintjük a projektvezetés szakmai tartalmát, azaz a szükséges projektvezetési eszközöket és ismereteket (Görög, 2013a).

Jellegükből fakadóan a projektképességek is igen összetett, komplex ismeretkört, tudást jelentenek. Több megközelítés is született ezzel kapcsolatban (Görög, 2013a), azonban a disszertáció Cleland (1994) álláspontját mutatja be, köszönhetően a projekt és a projektsiker értelmezésének fejlődésével való szoros összefüggés miatt. A projektképességek magukban foglalják mind a projektvezetői ismereteket, mind azok alkalmazásának képességét, továbbá azokat, amelyek projektvezetőhöz kapcsolhatók (ilyen például a szemléletmód). Cleland (1994) három szintet különböztetett meg egymástól, úgymint (7. ábra):

• ismeret, 
- alkalmazási készség,

• szemléletmód.

\section{0. ábra: A projektvezetési specifikus képességek szintjei}

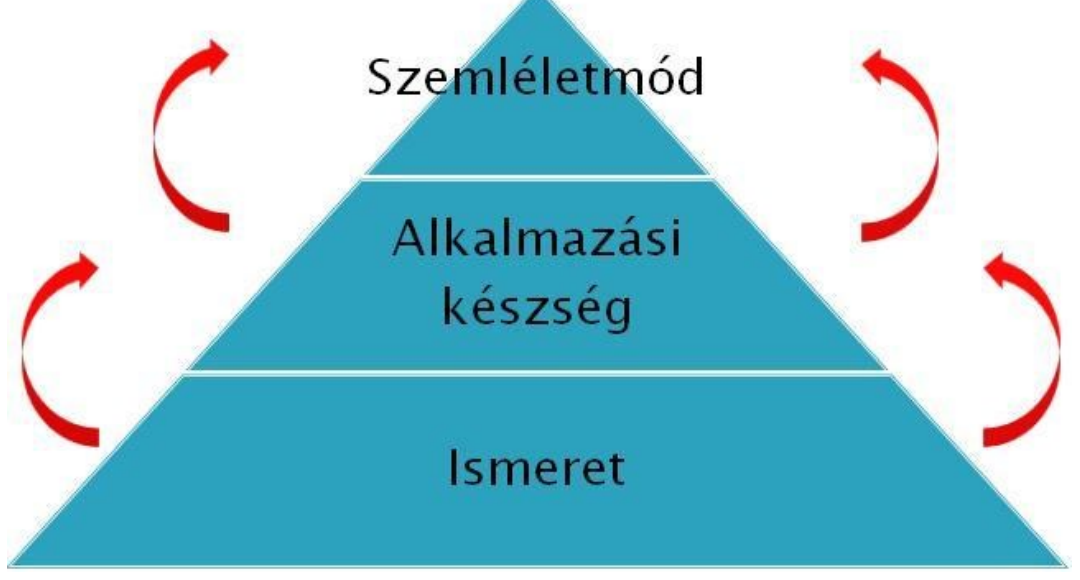

Forrás: Cleland (1994) alapján saját szerkesztés

Az első szint az ismeret, amelynek során a projektvezető ismeri az adott projektvezetési módszert (pl. időterv szerkesztésének ismerete). Könnyen felismerhető, hogy ez a legalsó lépcsőfok, hiszen az ismeret még nem garantálja önmagában a megfelelö alkalmazást is.

A második szint az alkalmazási készség, amikor nem csak ismeri az adott eszközt, hanem képes is alkalmazni azt. Könnyen felismerhető, hogy ez a dimenzió óhatatlanul magában foglalja az előző, az ismeret dimenzióját is, azaz az adott ismeret birtoklása nélkül nem lehet alkalmazni azt, még akkor sem, ha rendkívül kiterjedt szakirodalom áll rendelkezésre.

A harmadik dimenzió a szemléletmód, amely nem csak az ismeretet és az alkalmazási készséget rejti magában, hanem a projekt során alkalmazandó szemléletmódot, azaz az eszközöket miként használja vagy illeszti projektkontextushoz. Két megközelítés született ezzel kapcsolatban (Cleland, 1994; Görög, 2013a):

- kontextus-centrikus szemléletmód,

- a projekt értelmezése szerinti szemléletmód.

Az első megközelítés azt foglalja magában, hogy a projektvezető figyelembe veszi-e a projekt külső és belső környezeti sajátosságait, mikor alkalmazza a 
kvalitatív és kvantitatív projektvezetési eszközöket a projektek vezetése során, vagy valamilyen „,best practice”-t alkalmaz.

A második megközelítés a projektvezető projekthez való viszonyulást foglalja magában (vö. Görög, 2013a). Amennyiben a projektre mint egyedi feladatra tekint a projektvezető, akkor a projektvezetés fö feladata a projektfolyamat menedzselése. Így elsősorban a hangsúly a tervezésre, a kontrollra és az optimalizálásra helyeződik. Amennyiben a projektre mint ideiglenes szervezetre tekint a projektvezető, akkor a fö feladata ennek az ideiglenes szervezetnek, föként a projektcsapatnak a vezetése. Ebben az esetben a legfőbb eszközei többek között a megfelelő kommunikáció és motiválás. Amennyiben a projektre mint stratégiai építőelemre tekint a projektvezető, akkor a projektvezetés fő feladata a projekt során létrejövő kedvező változás realizálásának menedzselése. Ez pedig az olyan elemek felé tolja a hangsúlyt, mint a behatárolás, kommunikáció, optimalizálás vagy a változáskezelés (vö. Judgev - Müller, 2005). Természetesen könnyen elöfordulhat, hogy a projektvezető a három bemutatott szemléletmódból nem csak egyiket követi, hanem azok valamilyen kombinációját. Ez összhangban áll azzal a megközelítéssel, hogy a projektteljesítés során más és más elemekre helyeződik a hangsúly, amely leképeződhet a szemléletmódban is.

A szemléletmód természetesen átfedésben áll a korábban bemutatott két másik képesség-területettel, a humán és technikai területtel (különösen a projekt értelmezése szerinti szemléletmód). Azonban a szemléletmód mindenképp túllép ezeken, hiszen nem „csupán” egy-egy tudás vagy tudásterület, képesség birtoklását jelenti, hanem azt a megközelítést, amik alapján alkalmazza ezeket a tudásterületeket, képességeket.

Összességében megállapítható tehát, hogy a projektvezető szükséges tudása manapság igen összetett, több területet is magában foglal. Óhatatlanul szükséges a projekt szakmai tartalmára vonatkozó tudás, hiszen enélkül nem lehet a projektháromszögre vonatkozó paramétereket meghatározni, azonban ez manapság már nem elégséges. Szükséges az érintettek (különösen a projektcsapat) kezelésére vonatkozó képességek, tudás birtokában lennie a projektvezetőnek, különben vezetésük/kezelésük nem lehet hatékony és hatásos, márpedig ez óhatatlanul a projekt sikertelenségével végződhet (vö. Fortune - White 2006; Kappelman et al. 2006). Emellett szükséges a projektvezetés szakmai tartalmával kapcsolatos 
eszközöket is birtokolnia. Ez utóbbi további három részre bontható ${ }^{37}$, úgymint ismeret, alkalmazási készség és szemléletmód. A legmélyebb szintet a szemléletmód jelenti, amely azt foglalja magában, hogy a projektvezető miként alkalmazza a kvantitatív vagy kvalitatív projektvezetési eszközöket vagy illeszti projektkörnyezethez.

\subsubsection{A projektvezetési eszközök csoportosítása}

A projektvezetési eszközök óhatatlanul eltérő jellegűek egymástól. A kezdeti „hard” elemek mellett, amelyek elsősorban az idő, költség, minőség hármasára koncentráltak, megjelentek a „szoftabb”, nehezebben kvantifikálható eszközök is. Így a projektvezetési eszközök során ma már megkülönböztethetünk (Görög, 2013a):

•Kvantitatív projektvezetési eszközök: amelyek számszerüsített formában kezelik a projekt során fellépő igényeket. Ilyenre példa a költség- vagy időterv, de lehetne még említeni a kockázatelemzés során használt eszközök túlnyomó többségét is.

-Kvalitatív projektvezetési eszközök: jellegüknél fogva nem számszerüsített módon kezelik az adott problémát, hanem leíró volta miatt átfogóbb módon igyekeznek választ adni a projekt során támasztott igényekre. Ilyen lehet például a projekt során alkalmazott kommunikáció.

Természetesen előfordulhat, hogy egy projektvezetési feladatnak lehet kvalitatív és kvantitatív része is, hiszen például az időterv elkészítésénél vagy az egyes tevékenységek közti összefüggések meghatározása révén nyert projektút kiszámítása kvantitatív eljárás, míg a tevékenységek meghatározása kvalitatív (vö. Fekete, 2000). Azonban ki lehet jelenteni, hogy a legtöbb egymástól élesen elválik (pl. érintettek kezelése nélkülözi a kvantitatív elemeket) vagy a kvalitatív vagy kvantitatív jelleg dominál az adott eszközben (pl. az időtervezésben a kvantitatív).

Ugyanakkor szükséges felhívni a figyelmet arra a tényre, hogy jellegükből fakadóan más és más sikerkritériumra gyakorolnak hatást az egyes eszközök. Görög (2008) összegyüjtött több technikát és ezek hatását az egyes sikerkritériumra (5. táblázat).

\footnotetext{
${ }^{37}$ Természetesen a másik két tudásterület is komplex, összetett, azonban a disszertációnak nem célja ezek mélyebb bemutatása.
} 
5. táblázat: A projektvezetési eszközök hatása a sikerkritériumokra

\begin{tabular}{|l|l|}
\hline Sikerkritériumok & Projektvezetési eszközök \\
\hline Projektháromszög & $\begin{array}{l}\text { Időtervezés, erőforrás-tervezés, } \\
\text { költségbecslés } \\
\text { Kockázatok értékelése } \\
\text { Folyamatkontroll (EVA) }\end{array}$ \\
\hline Projekttulajdonosi megelégedettség & $\begin{array}{l}\text { Tartalmi-terjedelmi behatárolás } \\
\text { Az életképesség értékelése } \\
\text { Projektszervezetek/projektfelügyelet } \\
\text { Projektteljesítési stratégia } \\
\text { Eredménykontroll }\end{array}$ \\
\hline Érintettek megelégedettsége & $\begin{array}{l}\text { Érintettek elemzése } \\
\text { Projektmarketing }\end{array}$ \\
\hline
\end{tabular}

Forrás: Görög (2013b), 20. oldal

A szerző felhívja a figyelmet arra, hogy az első négy kvantitatív, míg a másik 7 kvalitatív eszköz. Így ki lehet jelenteni, hogy a kvantitatív technikák elsősorban a projektháromszög szerint értelmezett sikert segítik elö, míg a kvalitatív technikák a projekttulajdonos és érintettek elégedettségét.

$\mathrm{Az}$ összegzés legnagyobb hibája, hogy az indirekt hatásokat nem veszi figyelembe Görög (2013b). Hiszen a megfelelő projektmarketing alkalmazása révén a projektcsapat jobban motiválttá válik. Amely elősegítheti a projektháromszög szerinti siker teljesülését. Ugyanúgy a kommunikáció (mint projektmarketing eszköz) hatással lehet a projekttulajdonosi elégedettségre is. Így a táblázatot nem lehet pontosnak tekinteni, kiindulási alapot azonban képezhet a későbbi vizsgálatokhoz.

Továbbá szükséges megállapítani, hogy a projektvezető feladatain belül szintén dominálnak az egyes kvalitatív vagy kvantitatív eszközök (pl. a teljesítési 
tervek elkészítésében a kvantitatívak), amire a táblázatból szintén csak következtetni lehet.

Összességében ki lehet jelenteni tehát, hogy a projektvezetési eszközöket is két csoportra lehet osztani, egyfelől a számszerüsíthető eredménnyel rendelkező kvantitatív technikákra, másfelöl pedig a problémát leíró módon megadó és ezekre megoldást is hasonlóképpen adó kvalitatív technikákra. Azonban mindkettő szükséges manapság, hogy a projektet hatékonyan vezessék, ugyanis a kettő együttes alkalmazása nélkül a projekt fontosabb termékei és a teljesítés során felmerülö problémák kezelése nem válik lehetségessé (vö. 2.5 fejezet).

\subsubsection{A projektmenedzser explicit és tacit tudása}

Másfajta megközelítést jelent a projektmenedzsment tudás osztályozása szempontjából az ún. explicit és tacit tudás. Az explicit tudás ebben az értelemben a könnyen kvantifikálható, tanult és könnyen átadható tudást jelenti. A különböző szakkönyvek elsősorban az explicit tudás átadására törekednek. Míg a tacit tudás a beágyazott tudást jelenti, azt, aminek elsajátítása sokszor évekbe kerül (vö. Fehér, 2004; Davenport - Prusak, 1998). Azaz az explicit tudás inkább megtanulható, míg a tacit tudás inkább elsajátítható. Amennyiben összevetjük az egyes eszközöket a tudás jellemzésével, könnyen belátható, hogy mind a kvalitatív mind pedig a kvantitatív eszközök között felfedezhető tacit és explicit tudás is. Például az időterv meghatározásában a számolás főként explicit, míg a tevékenységek összegyűjtése sokszor inkább tacit jelleget ölt. Hasonlóképp az érintettek elemzése során a számolás és bizonyos szintig a kategorizálás explicit tudást feltételez, míg a releváns érintettek körének meghatározása elsősorban tacit tudást igényel (vö Davenport Prusak, 1998; Görög, 2007).

Hasonlóképp a kvalitatív és a kvantitatív eszközökhöz a technikai, a humán és a projektvezetési specifikus képességek is magukon viselnek tacit és explicit jellegeket is. Például a technikai képességek egy része elsajátítható egyetemen (elég csak a különbözö pénzügyi modellezési technikákra gondolni), másik része csak a nehezen vagy a gyakorlatban szerezhető meg (elég csak a különböző torzító faktorok pontos becslésére gondolni). Hasonló a helyzet a humán képességekkel. Példának okáért különböző tárgyalástechnikákat vagy konfliktuskezelést a legtöbb gazdasági 
iskolában oktatnak, azonban a megfelelő kontextusba helyezéséhez hosszú évek gyakorlati életben eltöltött tapasztalata szükséges.

Ettől némiképp eltérnek a projektvezetési specifikus képességek. Az ismeret és alkalmazási készség dimenziók jól elsajátíthatók pl. a jelenleg létező szakkönyvekből, azonban a szemléletmód olyan tényező, amelyet a projektvezető sokszor csak hosszú idő elteltével vallhat magáénak (vö. Davenport - Prusak, 1998). Példának okáért a projektvezető értelmezheti a projektet mint stratégiai építőelemet, azaz a vállalati stratégiával összhangban alakítja ki azt, azonban megfelelö előképzés vagy „hajlam” nélkül sokszor ez nem valósulhat meg. Így kijelenthető, hogy a harmadik dimenzió, a szemléletmód már jóval több tacit tudást tartalmaz, mint az eddigi területek. Természetesen ezzel nem azt állítom, hogy a másik két dimenzióban kizárólag explicit tudás van jelen, és nincs tacit, illetve azt, hogy a szemléletmódba nem tartoznak explicit elemek.

A projektvezetési szakirodalmak főként a tudás átadására koncentrálnak (ld. pl. Lindner - Wald, 2011; Pollack, 2012), nem szentelnek annak figyelmet, hogy az eszközökön, tudásterületen vagy kompetencián belül milyen típusú tudás van nagyobb mértékben jelen. Így ennek vizsgálata fontossá válhat.

\subsection{A projektvezető személyiségjegyei}

Ahhoz, hogy a projektvezető hatásosan és hatékonyan vezessen egy projektet, a projektvezetői tudás különböző aspektusain túl szükséges, hogy egyéb képességekkel rendelkezzen. Ilyen a vezetésének módja (amiről részletesebben ld. a következő fejezet) és a személyiségjegyek. Személyiségjegyeknek lehet tekinteni minden olyan tulajdonságot, amely veleszületett és nehezen fejleszthető (Görög, 2013a). Bár a személyiségjegyeket sokan a kompetencia bizonyos aspektusának tekintik és összemossák a projektvezető egyéb jellemzőivel (ld. pl. Dulawicz Higgs, 2003; Müller - Turner, 2010). Ugyanis (hasonlóan a vezetési stílushoz) a tudásterületek hatásosságát felerősítheti vagy gyengítheti a projektvezető személyiségjegye. Például egy jó empatikus képességgel rendelkező projektvezető általában könnyebben és gyorsabban meg tudja oldani a projekt során felmerülö, személyhez kapcsolódó problémákat vagy konfliktusokat. Azonban a személyiségjegyek (ellenben pl. a képességekkel, vezetési stílussal) veleszületettek, nehezen fejleszthetőek. Míg a képességek általában tanulással vagy viszonylag rövid 
idő alatt fejleszthetőek, addig az alapvető tulajdonságait megváltoztatni egy személynek igen körülményes és nehézkes (ld. pl. Cloninger 1994). Ezek alapján megállapítható, hogy a személyiségjegyet nem lehet egyként és összevontan kezelni a képességekkel vagy az ehhez vagy annak bizonyos aspektusaként értelmezni. Azonban megállapítható, hogy a kapcsolat a kettő között igen erös, hiszen a személyiségjegyeken keresztül érvényesülhet a projektvezetői képesség (Görög, 2013a).

Megállapítható továbbá, hogy a projektvezetőnek szükséges bírnia bizonyos személyiségjegyekkel, azonban ezek bizonyos tekintetben eltérnek a hagyományos menedzseri területektől. A projektmenedzsernek (összhangban a projekt értelmezésének fejlődésével) egyszerre kell menedzselni a projektfolyamatot, vezetni az ideiglenes szervezetet és a szervezet számára történő kedvezető változást implementálni. Ebböl fakadóan a feladata összetett, azaz eltérő és igen tág kompetenciaterületre van szüksége, és ebből fakadóan több személyiségjegyre is. A legtöbb szerző az érintettekhez kapcsolódó kompetenciák szükségességére hívja fel a figyelmet, mint pl. motiválás képessége vagy az empátia képessége (ld. pl. Clarke, 2010; Goleman, 2004; Nauman et. al., 2010). Ez több tényezőből fakadhat. Egyrészt fakadhat abból, hogy az emberekkel történő kapcsolattartás rendkívül szerteágazó, bizonyos érzék nélkül nem vagy csak nagyon nehezen lehet hatékonyan kommunikálni velük (vö. Görög, 2013a; Yang et. al., 2011). Másrészt fakadhat abból, hogy ez a folyamat rendkívül nehezen tehető jól strukturálttá. Míg egy terv megalkotása során lehet hasonló lépéseket követni (vö. Project Management Institute 2008), addig a projektben résztvevőkkel való kommunikáció során ez csak ritkán fordulhat elő. Természetesen ez nem azt jelenti, hogy nincs ilyen eleme (ld. pl. kommunikációs stratégia), hanem azt, hogy itt jóval nagyobb a nem strukturálható problémák aránya (vö. Cleland, 1994). Ugyanakkor az is igaz, hogy a tervezés során is felmerülhetnek váratlan események, ilyenkor a projektvezetőnek gyorsan és jól kell reagálnia, azaz improvizálnia kell (vö. Görög, 2003), ami szintén veleszületett, nehezen tanulható. Így összességében megállapítható, hogy a projektvezető által szükségesnek vélt személyiségjegyek többsége az érintettekhez kapcsolódó veleszületett képesség, azonban más aspektusait is figyelembe kell venni. 
Ezzel összhangban alakította ki Dulawicz és Higgs (2003) a projektvezető által birtoklandó kompetenciákkal (a vezetési stílusok függvényében), amelyek a következők:

• kritikai elemzö-, és ítélőképesség,

• elörelátás és képzelőerő,

- stratégiai perspektivikusság,

•kommunikációs készség,

• erőforrás kezelése,

- feljogosítás,

• kidolgozás,

• megvalósítás,

• öntudatosság,

• érzelmi szilárdság,

- motiváció,

• fogékonyság,

• befolyásolás,

• intuíció,

- lelkiismeretesség.

Az első hármat az intellektuális kompetenciák, a második ötöt a vezetői kompetenciák, az utolsó hetet az érzelmi kompetenciák közé sorolta. Azonban belátható, hogy ezek közül vannak tudásterületek, amelyek tanulhatóak, és vannak személyiségjegyek, amelyek fejleszthetőek és veleszületettek. A kidolgozás, a megvalósítás, az erőforrások kezelése olyan tulajdonság, amit lehet tanulni, még akkor is, ha a szerzőpáros a hagyományos értelemben vett tervezésnél és kontrollnál mélyebb és tágabb jelentést tulajdonított neki. Ezen túl van még olyan kompetencia is, ami egy személyiségjegyen keresztül kerül érvényesülésre. Ilyen a kritikai elemző-, és ítélőképesség és az elörelátás bizonyos vetülete, valamint a kommunikációs készség. A stratégiai perspektivikusság inkább attitűd, semmint 
valódi személyiségjegy. Míg a feljogosítás (empowerement) inkább eszköz, amin keresztül elérheti célját a projektvezető. Azonban a többi valóban tekinthető a klasszikus értelemben vett személyiségjegynek. Azonban ha azt tekintjük kiindulási alapnak, hogy mi a projektvezető feladata (összhangban a projekt értelmezésével), akkor megállapítható, hogy a kritikusság, a képzelőerő, az öntudatosság, az érzelmi szilárdság, a motiváció, a fogékonyság, a befolyásolás, az intuíció és a lelkiismeret közül a képzelőerő, az érzelmi szilárdság, a motiváció, a fogékonyság (főként az empátia irányából értendő), a befolyás és az intuíció az, ami igazán mérvadó személyiségjegy ${ }^{38}$.

Hasonló megközelítés alapján (azaz az ideális vezető alapján) fogalmazta meg Goleman (2004) a szükséges kompetenciákat, amelyek: öntudatosság, érzelmi szilárdság, motiváció, empátia és szociális képességek. Míg Ivancevich et. al. (1977) azt találta, hogy a pszichológiai jellemzők, szociális háttér, intelligencia, munkához való hozzáállás és szociális képességek azok, amik fontos kompetenciák. Megállapítható ezekből, hogy Goleman (2004) kompetenciáit személyiségjegynek lehet tekinteni, míg Ivancevich (1977) egybevonja a tulajdonságot, szemléletmódot és a projektvezető hátterét, így kijelenthető, hogy valódi személyiségjegyek ezek között nincsenek.

Stevenson és Starkweather (2007) azt találta, hogy a projektvezető vezetési stílusa, szóbeli és írásbeli kommunikációs képessége, hozzáállása, a bizonytalansággal való megbirkózása és azon kompetenciája volt fontos, amely képessé teszi, hogy egyszerre több szinten kommunikálni. Ezek közül azonban csak a kreativitás (bizonytalansággal való megbirkózás) tekinthető valódi személyiségjegynek. Crawford és Nahmias (2010) is hasonló eredményre jutott, azaz a változásokkal való megbirkózás (és így a kreativitás) válik fontossá.

Mindezekkel összhangban gyüjtötte össze Görög (2013a) a főbb személyiségjegyeket, amikkel egy projektvezetőnek rendelkeznie kell:

\footnotetext{
38 A többi személyiségjegy nem áll összhangban a projektvezető feladatával, olyan személyiségjegyként lehet tekinteni rájuk, amely bármilyen vezetőre vagy vezető beosztású személyre igaz kell, hogy legyen. Az értekezés pedig projektvezetői szemszögből közelíti meg a személyiségjegyek kérdését.
} 
- Optimizmus (hozzáállás a projekthez): mivel a projekt egyszeri tevékenység/folyamat/szervezet, ezért óhatatlanul szükséges az ilyen jellegü attitűd a projekt sikere érdekében.

•Érzelmi intelligencia: a projektmenedzsernek szükséges bizonyos mérvü empatikus képességgel rendelkezni, amely révén megfelelően azonosítja a projekt érintettjeinek érzelmeit, és szükség esetén a helyes irányba tudja terelni.

- Csapatépítő képesség: a projektvezetőnek a projekt során általában a vállalati struktúra eltérő pontjáról érkező embereket kell egy csapattá kovácsolnia rövid idő alatt. Ráadásul itt a klasszikus értelemben vett csoportnyomás (mint pl. egy osztály esetén) nem jelentkezik, ugyanis a projektek során nem csak egy vagy kevés ember nem képezi részét még a csoportnak, hanem általában ismeretlen, nem összeszokott emberekből kell felépíteni azt.

- Bizalomépítő képesség: a projekt során óhatatlanul szükségessé válik a bizalom mind a projektmenedzser, mind a projekt iránt, és ez a személyiségjegy ennek megszerzését hivatott biztosítani (természetesen az érintettek irányából).

- Motivációs képesség: olyan képesség, amelynek segítségével a projektvezető képes rávenni valakit, hogy megtegyen olyan feladatot vagy feladatokat, amelyeket amúgy nem tenne meg.

- Improvizáció: amely során a projektmenedzser a váratlan helyzetekre képes reagálni, és a létező erőforrásokból a lehető legjobb megoldást kiválasztani. Görög ebbe a kategóriába sorolja a kreativitást is, hiszen a projektvezetőnek kreatívnak kell lennie, ugyanis az új helyzetekre csak akkor képes megfelelően reagálni, ha kellően kreatív, illetve természetesen az alkalmazott eszközök tárházára is hatással van a kreativitás (ld. pl. Magyari-Beck, 2006). Azonban ez az improvizációval szoros összefüggésben áll a kreativitással, hiszen improvizálni nem lehet kreativitás nélkül, és a kreativitás testesülhet meg az improvizációban. Így ez a személyiségjegy komplexen értelmezhető, hiszen több elemet foglal magában.

Belátható tehát, hogy ez a hat személyiségjegy összhangban áll a projektvezető korábban taglalt szerepkörével ${ }^{39}$. Az improvizáció segíti a projektfolyamat implementációját akkor, ha valamilyen váratlan eseményre kell reagálni, és hasonló

\footnotetext{
${ }^{39}$ a projektfolyamat implementálásával, az ideiglenes szervezet vezetésével és a kedvező változás bevezetésével.
} 
okból a kedvező változás bevezetését is. Az érzelmi intelligencia, a csapatépítő képesség, a bizalomépítő képesség és a motivációs képesség pedig az ideiglenes szervezet vezetésében nyújt segítséget. Az optimizmus pedig a projektvezető olyan immanens sajátossága kell, hogy legyen, amely az egész projektvezetés során megmutatkozva kellő lendületet tud adni a projekt minden szakaszában, így ez támogatni tudja mindhárom szerepkört. Természetesen ez nem azt jelenti, hogy ezeken túl ne lenne szükség bizonyos ismeretekre vagy képességekre, azonban ezek nem személyiségjegyek, hanem tanult képességek vagy olyan tudás, amit a projekt vezetése során alkalmaz. Ilyen például a projektterv elkészítése (amelynek során felhasználja a technikai és projektképességeket), a kontroll (amelynek során szintén a technikai és projektképességek kerülnek előtérbe) vagy a megfelelő szerződéstípus kiválasztása.

\subsection{A projektvezető vezetési stílusa}

A vezetés legfontosabb feladata, legyen az bármilyen menedzsment tevékenység, a koordináció biztosítása. Dobák (2005) három koordinációs mechanizmust különböztet meg, úgymint:

• strukturális,

- technokratikus,

- személyorientált.

A szerző az első alatt a hierarchikus vagy szervezeti megoldásokat érti, azt, ahogy a szervezet struktúrája kialakítása került (ide veszi többek között a projektet). A második, azaz a technokratikus alatt azokat a szabályzatokat érti Dobák (2005), amik révén a feladat elvégzésre kerül. A harmadik alatt pedig azokat az eszközöket érti, amik alatt az egyén azonosulhat a szervezet céljaival és az elvégzendő feladatokkal. Ide tartoznak olyan direkt és indirekt eszközök (pl. ösztönző, kényszerítő vagy ideológiai), amelyek révén a feladatok hatékonyabban és hatásosabban elvégezhetővé válnak. A szerző megemlíti, hogy a megfelelő eszköz vagy eszközök az adott szervezet helyzetétöl, berendezkedésétől függ vagy függenek.

Mivel Lundin és Söderlund (1995) megállapította, hogy a projekt ideiglenes szervezetként is tekinthető (egyedi feladat és stratégiai építőelem mellett), ezért 
megállapítható, hogy a fentebb említett koordinációs mechanizmusok megtalálhatók a projekteken belül is, azonban természetesen másként, mint egy klasszikus szervezetben (vö. Görög, 2013a). Amennyiben a vezetö (jelen esetben a projektvezető) szemszögéből vizsgáljuk a koordinációs mechanizmusokat, megállapítható, hogy a projektcsapatra a legnagyobb hatást a személyorientált koordinációs mechanizmus gyakorolja a legnagyobb mértékü hatást. Ugyanis ahogy Pinto (2000) megállapította, a projektvezető sokszor nem rendelkezik formálisan biztosított hatáskörrel. Valamint a technokratikus eszközök is a projekt hatékony és hatásos lebonyolítását segítik elő, ezeknek mintegy kivitelezője, nem pedig aktív alakítója. Ennek legmarkánsabb megnyilvánulási formái a projektvezetési eljárások, keretrendszerek és ajánlások, amelyek segítik a projektvezetőt a projektek vezetése során, ugyanakkor a rugalmasságot, a projektvezetési szabadságot is jelentősen csökkenthetik (vö. Kiss et al., 1993a; Project Management Institute, 2008). Mindezekből fakadóan a projektvezető a legnagyobb mértékben a személyéhez kapcsolódó koordinációs eszközzel tud élni ahhoz, hogy hatékonyan és hatásosan vezesse a projektet. Ez pedig többek között a vezetési stílusban ölt testet.

A projektvezető vezetési stílusa döntő a projektsiker szempontjából (ld. pl. Cleland, 1995; Fortune - White, 2006; Hall et. al., 2003; Kendra - Taplin, 2004; Wang etl.al., 2005), ennek megfelelően többen foglalkoztak ezzel a kérdéskörrel (ld. pl. Müller - Turner, 2007; Robbins, 1997). Vezetési stílus az „a vezetői magatartásforma (viszonyulás a vezetettekhez), amelyen keresztül egy vezető hatást gyakorol a vezetettekre egy kitüzött cél elérése érdekében" (Görög, 2013a, 67. oldal).

A vezetési stílust vizsgáló tanulmányok többsége két alapvető jelenségre fókuszáltak. Az egyik ezek közül a szélsőséges vezetési magatartásformák azonosítását tüzte ki célul, ilyen lehet például az autoriter vagy demokratikus irányzat (ld. pl. Fiedler, 1967; Nauman et. al., 2010, Yang et. al., 2011), a lassisez faire vagy a tervszerü megközelítés (ld. pl. Schmid - Adams, 2008) vagy az iránymutató vagy diktáló stílus (ld. pl. Goleman et. al., 2002; Goleman, 2004), esetleg egyéb (ld. pl. Turner - Müller, 2007). Ezek a tanulmányok természetesen nem azt állítják, hogy egyik vagy másik a követendő, sokszor hangsúlyozzák, hogy a kettőnek valamilyen kombinációja a megfelelő. A másik jelenség pedig a projektek eltérő voltának hatását vizsgálják a vezetési stílusra. Több szerző megállapította, 
hogy eltérő projekttípus vagy projektkörnyezet eltérő vezetésformák alkalmazását teszi szükségessé (ld. pl. Anantatmula, 2008; Prabhakar, 2005), igyekeztek olyan vezetési stílust meghatározni, vagy legalább olyan elemeket kiemelni a vezetési stílusokból, amelyek adott típusú projektre vagy projektkörnyezetre igazak lehetnek. Egyesek arra is felhívták a figyelmet, hogy a projekt különböző szakaszaiban más és más vezetési stílus lehet a célravezető (ld. pl Frame, 1987; Prabhakar, 2005; Turner, 1999b). Bár ettől eltérő megközelítések is születtek (ld. pl. Thomas - Bendoly, 2009), miszerint a vezetési stílus esetén a stabilitás kulcsfontosságú, és az adott projekten belül történő változtatása káros lehet a projektsiker elérése szempontjából.

Turner és Müller (2007; 2010) mindkét jelenséget vizsgálta. Az utóbbi esetében müszaki, IT és szervezetfejlesztési projektek esetén követendő vezetési formát próbált azonosítani, és arra a következtetésre jutott, hogy különböző elemek fontosak az egyes projekteknél. Emellett azonosították a szakirodalomban található vezetési stílusokat, amelyek a következők ${ }^{40}$ :

- Személyes vonásokon alapuló vezetési stílus: ennek a közelítésmódnak a lényege, hogy a projektvezetőnek olyan alapvető értékekkel kell rendelkeznie, amelyek elengedhetetlenek a projekt sikeréhez (mint pl. magabiztosság vagy vezetésre születés), és amennyiben ezek megvannak, a projektet sikeresen fogja vezetni.

•Viselkedésmódon alapuló irányzat: amely szerint különböző projektek különböző vezetési stílust igényelnek, ezért a projektvezető azon (fejlesztett vagy birtokolt) attribútumait kell alkalmaznia és olyan mértékben, amilyet a projekt megkíván. Ilyen lehet például a rugalmasság vagy az „empowerment”. A szerzőpáros megjegyezte továbbá, hogy a vezetési képesség fejleszthető.

- Kontingencián alapuló vezetési irányzat: az irányzat szerint szükséges azonosítani a projekt jellemzőit, és az ezekhez leginkább megfelelő attribútumokkal rendelkező vezetőt kell delegálni.

- Karizmán alapuló vezetési irányzat: az irányzat komplex, hiszen két altípusra bontható. Az egyik altípus szerint a vezető példamutatás és megfelelő személyiségjegyek által igyekszik a projektcsapat révén sikerrel kivitelezni a

\footnotetext{
${ }^{40}$ Emellett még megemlítette Konfuciusz, Arisztotelész és Barndt munkásságára épülő vezetési stílusát, azonban ezeket a projektek tudatos vezetése előtti időkre tette, így ennek bemutatásától jelen esetben eltekintenék.
} 
projektet. A másik altípus szerint a feladat teljesítésén van a hangsúly, és a jutalmazáson vagy a tervezettől való eltérésekre történő reagáláson van a fő hangsúly.

- Az érzelmi intelligencián alapuló irányzat: az irányzat alapvetően azon a feltevésen alapul, hogy a projektvezető érzelmi intelligenciája nagyobb mértékben járul hozzá a projektvezetéshez (és így a projektsikerhez), mint a vezetési stílusa. Ezért az iskola az érzelmi intelligencia négy összetevőjére helyezik a hangsúlyt a projektek vezetése során. Ez a négy elem a következő: önbizalom, önirányítás, szociális tudatosság és kapcsolatkezelés. Görög (2013a) a szakirodalom (és ennek a négy elemnek a kombinációja) alapján hat vezetési stílust határozott meg, úgymint: látnok, edző, kapcsolatépítő, demokratikus, tempót diktáló hajcsár és utasító. Ugyanakkor felhívja a figyelmet, hogy az utóbbi kettő - a káros következményei miatt - csak végszükség esetén alkalmazandó.

- Kompetencián alapuló irányzat: az irányzat a vezető kompetenciáinak fontosságát hangsúlyozza, azaz a megfelelő emocionális, vezetési és intellektuális képességekkel kell rendelkezni, és ezeket a megfelelő kombinációban kell alkalmazni (helyzettől függően) ahhoz, hogy a projekteket sikerrel vezetni lehessen. Müller és Turner (2007) a három képességcsoport alapján három vezetési stílust azonosít, úgymint: célorientált, involváló és kötelességtudó.

A szerzőpáros (Müller - Turner, 2007) megállapította továbbá, hogy az első négy irányzat főként a múltra volt jellemző, míg az utóbbi kettő, az érzelmi intelligencián alapuló irányzat és a kompetencián alapuló irányzat a 2000-es évek sajátja $^{41}$.

Ezek alapján megállapítható, hogy az egyes vezetési stílusok két alapvető lényegi különbséggel rendelkeznek. Az első, hogy a vezetési stílusok hatékonysága projekttípus és projektkörnyezet szerint eltérhet egymástól. A második pedig az, hogy milyen kompetenciák vagy személyiségjegyek ${ }^{42}$ járulnak hozzá az adott vezetési stílushoz. Azonban tartalmában hasonlóságot mutatnak, hiszen a célkövető

\footnotetext{
${ }^{41}$ Mivel a két tanulmány 2007-ben és 2010-ben jelent meg, ezért határolták be a szerzők csupán a 2000-es évekre, azonban megállapítható, hogy ezt ki lehet terjeszteni, és megfelelő lehet a 2010-es évekre is.

${ }^{42}$ A szakirodalom következetesen jellemzőnek vagy kompetenciának hívja az egyes elemeket, azonban sok inkább személyiségjegyként aposztrofálható.
} 
vagy autoriter vezetést és a támogatót, mentor szerepkört és a köztük lévő irányzatokat igyekeznek meghatározni.

Megállapítható tehát, hogy mindegyik vezetési stílus a demokratikus irányzat és a diktatórikus irányzat mint két pólus közötti vezetési irányzatokat igyekszik meghatározni (vö. Blaskovics, 2014; Fiedler, 1967). Megállapítható továbbá, hogy az egyes pólusok vagy vezetési stílusok eltérő eszközökkel élnek. A diktatórikus stílusok föként a hierarchikus hatalomra (már amennyiben a szervezeti struktúra révén rendelkezik a projektvezető), a hatékony erőforrás-elosztásra, a tervezésre és a tervek betartására helyezi a hangsúlyt, míg a demokratikusabb irányzatok inkább a kommunikációra, a csapatmunkára és az empowermentre helyezi a hangsúlyt (vö. Müller - Turner, 2007). Ezt megerösíti, hogy a Fiedler (1967) által meghatározott két vezetési stílus, a feladat-centrikus és az érintett-centrikus vezetési stílus elemei megfigyelhetőek minden egyes irányzatban. Ahogy korábban is megállapításra került, a két pólus ritkán alkalmazható hatékonyan és hatásosan, inkább ezeknek valamilyen optimális kombinációja válik szükségessé a projektek vezetése során.

\subsubsection{A vezetési stílusok szakirodalmának hiányosságai}

Ahogy korábban bemutatásra került, a projektvezető vezetési stílusa kritikus sikertényező, és mint kritikus sikertényező, magán viseli a korábban említett hiányosságok egyikét. Azaz sokan a sikeres vezetési stílus megállapításánál arra koncentrálnak, hogy miként hatnak a projektsikerre (ld. pl. Hall et. al., 2003; Kendra - Taplin, 2004) . Azonban a projektsikert a legtöbben homogén fogalomként kezelik, nem bontják sikerkritériumokra. Ez föként a régebbi tanulmányok során volt jellemzö, a 2000-es évek közepe, vége óta többen is megbontották a projektsikert (ld. pl. Müller - Turner, 2007; Yang et. al., 2011).

A második hiányosság, hogy a vezetési stílust sokszor adottságként kezelik, és nem vizsgálják, hogy milyen személyiségjegyek vagy kompetenciák járulnak hozzá bizonyos vezetési stílusokhoz (ld. pl. Nauman et. al., 2010). Ezt a hiányosságot kezelik azok a tanulmányok, amelyek az utóbbi két iskolába tartoznak. Müller és Turner (2010) megvizsgálta azokat az emocionális, vezetési és intellektuális kompetenciákat, amelyek alapján az egyes vezetési stílusok kategorizálhatók (Dulawicz - Higgs, 2003 alapján). 
6. táblázat: A kompetenciák hatása a vezetési stílusra

\begin{tabular}{|c|c|c|c|c|}
\hline \multirow{2}{*}{$\begin{array}{l}\text { Kompetencia } \\
\text { csoportok }\end{array}$} & \multirow{2}{*}{ Kompetenciák } & \multicolumn{3}{|c|}{ Vezetői stílusok } \\
\hline & & Célorientált & Involváló & Kötelességtudó \\
\hline \multirow{3}{*}{$\begin{array}{l}\text { Intellektuális } \\
\text { kompetenciák } \\
\text { (IQ) }\end{array}$} & $\begin{array}{l}\text { Kritikai elemzö- } \\
\text { és ítélőképesség }\end{array}$ & Magas & Közepes & Közepes \\
\hline & $\begin{array}{l}\text { Előrelátás és } \\
\text { képzelőerő }\end{array}$ & Magas & Magas & Közepes \\
\hline & $\begin{array}{l}\text { Stratégiai } \\
\text { perspektivikusság }\end{array}$ & Magas & Közepes & Közepes \\
\hline \multirow{5}{*}{$\begin{array}{l}\text { Vezetői } \\
\text { kompetenciák } \\
\text { (MQ) }\end{array}$} & $\begin{array}{l}\text { Kommunikációs } \\
\text { készség }\end{array}$ & Közepes & Közepes & Magas \\
\hline & Erőforrás kezelés & Magas & Közepes & Alacsony \\
\hline & Feljogosítás & Alacsony & Közepes & Magas \\
\hline & $\begin{array}{l}\text { Kidolgozás } \\
\text { (tervezés) }\end{array}$ & Közepes & Közepes & Magas \\
\hline & $\begin{array}{l}\text { Megvalósítás } \\
\text { (teljesítés) }\end{array}$ & Magas & Közepes & Közepes \\
\hline \multirow{7}{*}{$\begin{array}{l}\text { Érzelmi } \\
\text { kompetenciák } \\
\text { (EQ) }\end{array}$} & Öntudatosság & Közepes & Magas & Magas \\
\hline & Érzelmi szilárdság & Magas & Magas & Magas \\
\hline & Motiváció & Magas & Magas & Magas \\
\hline & $\begin{array}{l}\text { Fogékonyság } \\
\text { (érzékenység) }\end{array}$ & Közepes & Közepes & Magas \\
\hline & Befolyásolás & Közepes & Magas & Magas \\
\hline & Intuíció & Közepes & Közepes & Magas \\
\hline & Lelkiismeretesség & Magas & Magas & Magas \\
\hline
\end{tabular}

Forrás: Müller - Turner, 2010, 438. oldal ${ }^{43}$

Azonban, ha összehasonlítjuk a meghatározásra került alapvető projektvezetői személyiségjegyekkel, könnyen belátható, hogy jelentős eltérések mutatkoznak, hiszen pl. a csapatépítő képesség vagy a bizalomépítő képesség hiányzik. Hasonló hiányosságokat lehet felfedezni a többi szakirodalom esetén (ld. pl. Fiedler, 1967; Goleman, 2004; Ivanchevich et. al., 1997).További hiányosságként lehet azonosítani, hogy nem fordítanak figyelmet arra, hogy a vezetési stílus kialakulását (vagy változását) tudásterületek, tulajdonságok vagy személyiségjegyek okozzák, vagy esetleg más tényező.

Összességében megállapítható tehát, hogy a vezetési stílus kiterjedt szakirodalommal rendelkezik, és általában két szélsőség között igyekszik meghatározni projekttípus és projektkörnyezet szerint az ideális vezetői magatartást. Bizonyos tanulmányok arra is ráirányították a figyelmet, hogy milyen

\footnotetext{
${ }^{43}$ Müller és Turner (2010) angolról magyarra történő fordítása során Görög (2013a, 71. oldal) megnevezéseit használtam.
} 
személyiségjegyek vagy egyéb kompetenciák járulnak hozzá/kellenek az adott vezetési stílushoz. Azonban a projektvezető jellegzetes személyiségjegyeire (ld. 4.3. fejezet) az ilyen tanulmányok nem fordítanak kellő figyelmet, inkább általános vezetői kompetenciákat, személyiségjegyeket említenek. Továbbá nem vagy nem kellő mértékben kezelik a változás lehetőségét. Így megállapítható, hogy a projektvezető korábban azonosított hat személyiségjegyének vezetői stílusra gyakorolt hatása még nem került meghatározásra, különösen annak fényében, hogy amennyiben azok fejlődnek, akkor változik-e a vezetői stílus is.

\section{4 Összefoglalás}

Összességében megállapítható tehát, hogy a projektvezetési kompetencia önmagában igen tág, összetett fogalom. Egyik összetevője a projektvezetési képességek, amelyek a projektvezető elvárt tudását foglalják magukban (Görög, 2013a). A projektvezetési képességek fejlődése összhangot mutat a projekt értelmezésének fejlődésével. Hiszen a technikai képességek mellett ma már fontosak a humán, emberhez kötődő és a projektvezetési specifikus képességek is. Ez utóbbi azonban már túlmutat a képességen mint kompetenciaelemen, hiszen (az ismeret és alkalmazási készség mellett) a projektvezetési szemléletmódot is tartalmazza. Azaz azt, hogy a projektvezető miként tekint a projektre. Bár a szakirodalom részletesen taglalja az elvárt képességeket, azonban kevés figyelmet szentel figyelmet, hogy a kvalitatív és kvantitatív eszközök (mint a képességek leképeződései) milyen sikerkritérium teljesülését segítik elö. Mintahogy arra sem, hogy a tacit vagy explicit tudás van nagyobb mértékben jelen a képességeken (különösen a szemléletmódon) belül.

Másik területe a kompetenciának az ún. személyiségjegyek. A szakirodalom alapján azonban meg lehet állapítani, hogy az ezzel foglalkozó müvek hiányosak, hiszen ezek célkitüzése elsődlegesen az elvárt kompetenciák azonosítása, nem pedig specifikusan személyiségjegyeké. Azonban a müvek alapján (figyelembe véve a személyiségjegy alapvető sajátosságait) össze lehet gyüjteni a projektvezető főbb személyiségjegyeit, amelyek: optimizmus, érzelmi intelligencia, csapatépítő képesség, bizalomépítő képesség, motiváló képesség és improvizáció. Azonban ennek a hatnak a hatása nincs feltérképezve sem a szemléletmódra (holott a képességek, ismeretek teljesülését segítik elő ezek), sem pedig a vezetési stílusra. 
Annak ellenére sem, hogy a vezetési stílus szakirodalma rendkívül gazdag. Azonban ezek a müvek főként a megfelelő vezetési stílus azonosítására és a vezetési stílus projektsikerre gyakorolt hatására fókuszálnak. Azok, amelyek mégis figyelmet szentelnek annak, hogy milyen kompetenciák járultak hozzá a vezetési stílus kialakulásához, nem különböztetnek meg pl. képességeket, tulajdonságokat, személyiségjegyeket. 


\section{Empirikus kutatás: a projektvezető jellemzőinek hatása a projektvezetési szemléletmódra, vezetési stílusra és a sikerkritériumokra}

A kutatás alapvető célja, hogy lehetővé tegye a projektsiker elérésének jobb megértését. Ehhez szükséges, hogy kimutassa a kapcsolatot az egyik kritikus sikertényezőnek tartott jellemző, a projektmenedzser jellemzőinek (a korábbiak értelmében ebbe a projektvezetöi képességek, a vezetési stílus és a személyiségjegyek tartoznak) egyes aspektusai valamint a projektsiker között. Azaz kimutatni a projektvezető projektvezetési szemléletmódjának hatását a projektsiker három szintjére, a projektháromszögre, a projekttulajdonosi elégedettségre és az érintettek elégedettségére, valamint a személyiségjegyek hatását a vezetési stílusra és a projektvezető projektvezetési szemléletmódjára.

A kutatás fontosságát elsősorban az adja, hogy az eddigi képzések túlnyomó többsége az ismeretek átadására koncentrál, nem vagy csak minimális hangsúlyt helyezve a szemléletmód alakítására vagy a kontextusban történő oktatás fontosságára. Amennyiben sikerül kapcsolatot kimutatni a két tényező között, akkor támpontot nyújthat a projektvezetési képzések struktúrájának és tartalmának fejlesztést illetően. Ahhoz, hogy támpontot nyújthasson a képzések átalakítási szükségességének megítélésében, szükséges a korábban említett kapcsolatok kimutatása mellett a tacit és explicit tudás arányának vizsgálata is. Amennyiben a projektvezetők úgy itélik meg, hogy az explicit tudás legalább olyan fontossággal bír, mint a tacit tudás, akkor az átalakítás nem válik szükségessé, hiszen a hangsúlyt a jelenleg is a sok helyen alkalmazott ismeretátadásra kell helyezni.

Emellett a vállalatok számára fontossá válhat a projektvezetők tudásának, szemléletmódjának feltérképezése, hiszen ezen ismeretek fényében tovább növelhetik a projektsiker elérését.

A kutatás célja tehát a kapcsolat kimutatása a korábban említett tényezők, azaz a szemléletmód és a projektsiker, személyiségjegyek és a vezetési stílus között. Nem képezi részét viszont sem egy tudástérkép elkészítése, sem egyetlen kurzus megreformálása, szakkönyv átírása, sem pedig a kapcsolat szorosságának/mértékének kimutatása. Természetesen ez nem jelenti azt, hogy a 
kutatás egy későbbi lépcsőfoka ne lehetne ezek bármelyike. Azonban ahhoz, hogy ezek megtörténhessenek, mindenekelőtt a kapcsolat létét kell igazolni.

\subsection{A kutatás elméleti alapjai}

A kutatás elméleti alapját a következő tényezők jelentik:

-A kritikus sikertényezőket ért kritikák.

- A projektmenedzsment attitüd hatásának vizsgálata, illetve ennek hiánya (összhangban a projekt és a projektvezetés értelmezésének fejlődésével).

- A hasonló kutatások hiánya.

\subsubsection{A kritikus sikertényezőket ért kritikák}

A kritikus sikertényezőket négy komoly kritika érte. Ezeket mindenképpen figyelembe kell venni. Ezek a következök:

K1: A kritikus sikertényezők fontosságának időbeli változása nem kerül figyelembevételre.

K2: A kritikus sikertényezők közötti kölcsönhatás nem kerül figyelembevételre.

K3: A kritikus sikertényezők projekt- vagy projekttípus specifikusak, általános kritikus sikertényezők megfogalmazása nehézségekbe ütközik.

K4: A kritikus sikertényezőkkel foglalkozó vizsgálatok a projektsikert homogén fogalomként kezelik.

Ezek a következőképp kerültek figyelembe vételre a kutatás során:

K1 figyelembe vétele: Kutatásomban olyan kritikus sikertényező csoportot vizsgálok, amely a projektvezetőhöz kapcsolódik, azaz a projektvezető projektvezetési szemléletmódját, a vezetési stílusát és a személyiségjegyeit (vö. Fortune - White, 2006). A projektvezető szerepe pedig óhatatlanul kiemelt hatással van a projekt minden szakaszában, így fontossága nem változik a projekt minden fázisában. 
K2 figyelembe vétele: Mivel kutatásomban egyetlen kritikus sikertényező csoportot veszek figyelembe (a projektvezető kompetenciáját és [vezetési] stílusát), ezért a makroszintű, azaz a sikertényező csoportok közötti kölcsönhatások figyelembevételére nincs szükség, lévén nem célja az értekezésnek a projektvezetői karakterisztikák hatását feltérképezni más kritikus sikertényező csoportokra. Mikroszinten pedig figyelembevételre kerül, hiszen a személyiségjegyek hatását vizsgálom a projektvezetési szemléletmódra és vezetési stílusra.

K3 figyelembe vétele: Bár a kritikus sikertényezők projektspecifikusak, és általános kritikus sikertényezők megfogalmazása nehézségekbe ütközhet, azonban az értekezésnek nem célja ilyenek azonosítása.

K4 figyelembe vétele: A kutatás a projektsikert nem homogén fogalomként kezeli, hanem a hierarchikus modell szerint értelmezi, azaz a projektháromszög, a projekttulajdonosi szervezet elégedettsége és az érintettek elégedettsége szerint bontja meg.

Mindezekből megállapítható, hogy a kutatás figyelembe veszi a kritikus sikertényezőket ért kritikákat.

\subsubsection{A projektvezető projektvezetési szemléletmód hatásának vizsgálata, illetve ennek hiánya (összhangban a projekt és a projektvezetés értelmezésének fejlödésével)}

A kutatás második kiindulópontját a projektvezető projektvezetési szemléletmódja jelenti. A kutatás során azon szemléletmód-értelmezés kerül figyelembevételre, amely a projekt és a projektvezetés változó, fejlődő értelmezéséből indul ki. Így a projektet már egyedi feladatként, ideiglenes szervezetként és stratégiai építőelemként kell értelmezni. Ebből fakadóan a projektvezető tekinthet úgy a projektre, mint egyedi feladatra, ilyenkor fö feladata a teljesítési folyamat vezetése. Tekinthet a projektre úgy, mint ideiglenes szervezetre, ekkor a fö feladata a projektszervezet vezetése. Tekinthet továbbá a projektre úgy, mint stratégiai építőelemre, ebben az esetben a fö feladata a kedvező változás elősegítése. Természetesen tekinthet ezek valamilyen kombinációjára is. Összességében megállapítható tehát, hogy a kutatásom egyik alapját Cleland (1994) projektképesség-megbontása adja, amelynek harmadik eleme a projektvezető projektvezetési szemléletmódja. . 


\subsubsection{A hasonló kutatások hiánya}

A kutatás fontosságát alátámasztja továbbá, hogy a hasonló kutatások hiányoznak. A projektsikerről, a sikerkritériumokról, a kritikus sikertényezőkről, a projektvezetőről, elvárt képességéről, személyiségjegyeiről és vezetési stílusáról számos tanulmány áll rendelkezésre. Azonban az értekezésben megfogalmazott célkitűzéseket (azaz a hatásokat) még nem vizsgálták. Nem vizsgálták még a projektvezetési szemléletmód hatását a projektsikerre, amely a hierarchikus modell hármas megbontása szerint kerül értelmezésre. Bár a személyiségjegyek (vagy kompetenciák) hatását a vezetési stílusra többen vizsgálták már (vö. Müller - Turner, 2010), azonban a Görög (2013a) által összegyüjtött hat személyiségjegy hatását még nem vizsgálták a vezetési stílusra. Továbbá ennek a hatos személyiségjegycsoportnak a hatását sem vizsgálták még a projektvezetési attitüdre.

Összességében megállapítható tehát, hogy kutatásomban a projektsiker output oldali megközelítése során a hierarchikus modellt fogadom el, amelynek elemei: a projektháromszög (idő, költség, minőség), a projekttulajdonosi szervezet elégedettsége és az érintettek elégedettsége. A személyiségjegyek során Görög (2013a) hatos megbontását tekintem alapnak, azaz: az optimizmust, a motivációs képességet, a csapatépítő képességet, a bizalomépítő képességet, az empatikus képességet és az improvizációt tekintem meghatározó személyiségjegyeknek.

\subsection{Kutatási kérdések és hipotézisek}

A kutatás célkitüzése kettős. Az első célkitüzés kimutatni a kapcsolatot (a kapcsolat létét és nem a mértékét) a projektsiker három szintje és a projektvezető projektvezetési szemléletmódja között. A második cél kimutatni a személyiségjegy hatását (a hatásának meglétét és nem a mértékét) a vezetési stílusra és a projektvezető projektvezetési attitüdjére. Azonban ahhoz, hogy elérje alapvető célját, azaz a projektsiker és a projektvezetői karakterisztikák jobb megértését lehetővé tegye, elengedhetetlen, hogy további célkitüzések is megfogalmazásra megfogalmazódjanak. Azaz harmadik célkitüzésként megfogalmazható, hogy kimutassa, milyen típusú tudás (tacit vagy explicit), illetve milyen projektvezetési eszközök (kvalitatív vagy kvantitatív) járulnak hozzá nagyobb mértékben a projektsikerhez. 
Mindezekből következően indokolt a következő kutatási kérdések megfogalmazása:

KK1: Milyen mértékben járulnak hozzá a kvalitatív és kvantitatív projektvezetési eszközök a projektsiker három szintjéhez?

KK2: Milyen jellegü (explicit, tacit) tudás van nagyobb mértékben jelen a projektvezető projektvezetési szemléletmódjában?

KK3: Gyakorol-e számottevő hatást a projektvezető projektvezetési szemléletmódja a projektsiker három szintjére?

KK4: Gyakorolnak-e számottevő hatást a személyiségjegyek a projektvezető projektvezetési szemléletmódjára és a vezetési stílusára?

A kutatási kérdéseket és a szakirodalmi részben feltárt összefüggéseket is figyelembe véve az alábbi hipotézisek kerültek megfogalmazásra:

H1: A kvantitatív projektvezetési eszközök nagyobb mértékben járulnak hozzá a projektsiker mindhárom szintjéhez, mint a kvalitatív projektvezetési eszközök.

H2: A projektvezető projektvezetési szemléletmódján belül az explicit tudás nagyobb mértékben van jelen, mint a tacit tudás.

H3: A projektvezető projektvezetési szemléletmódja befolyással bír a projektsiker mindhárom szintjére.

H4: A projektvezető személyiségjegyei befolyással bírnak a projektvezető projektvezetési szemléletmódjára és a vezetési stílusára.

Mindezek fényében a kutatás logikai modellje a következőképpen épül fel: 


\section{1. ábra: A kutatás logikai modellje}

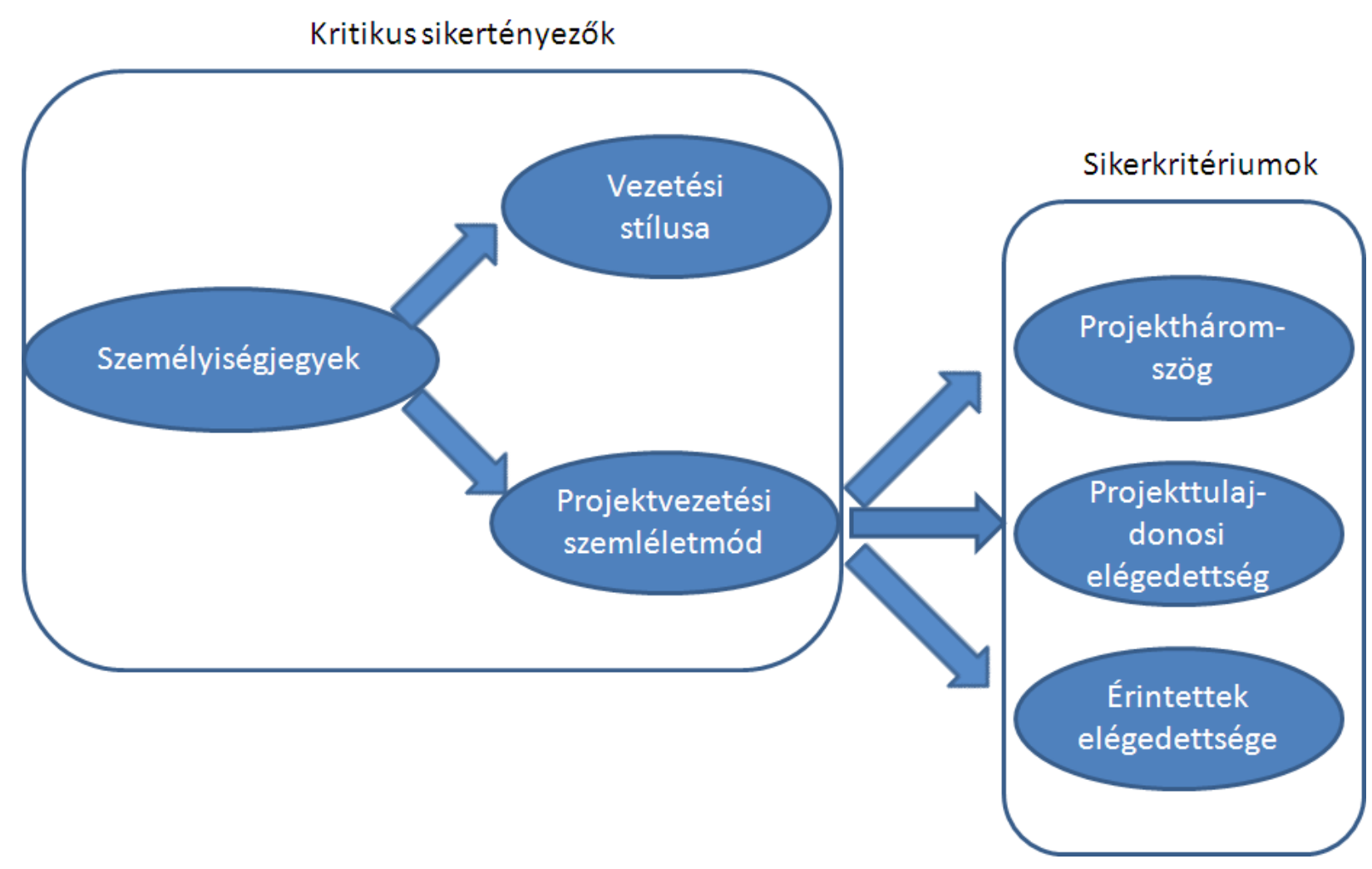

Forrás: saját szerkesztés

\subsubsection{A kutatás során használt módszertan}

A kutatás során felhasználható lett volna használni kvantitatív és kvalitatív módszereket, mint például kérdőívezés, tartalomelemzés, megfigyelés vagy interjúztatás.

Azonban a kvalitatív eljárás, és azon belül is az interjúkkal történő vizsgálat a legalkalmasabb a kutatási kérdések és hipotézisek megválaszolására (vö. Babbie 1994; Creswell 2003). Másik alkalmas módszer lehetne még a kérdőívek összeállítása és az alapján történő elemzés, azonban a hátrányait és elönyeit figyelembe véve ez a módszer elvetésre került. Bár az előnyei komolyak (gyorsaság, nagyobb minta, jó kódolhatóság), azonban a hátrányai jelentősebbek. Ugyanis a kérdőív érzékenyen reagál az esetleges kieső mintára, és jelentős esély mutatkozott arra, hogy a projektvezetők még megfelelő támogatás esetében sem hajlandóak kitölteni a kérdőívet. Természetesen ennek kezelésére több módszer lehetséges, pl. pótlólagosan kiküldeni újabb kérdöíveket vagy a ritkamátrix-kezelésének módszere. Azonban az előbbi nem garantálja, hogy az újabb alanyok kitöltik a kérdőíveket, a 
második esetében pedig az arányok nagyon torzulhatnak. További nagy hátránya a kérdőívezésnek a kutatás jellegéből fakad, nevezetesen a kérdéseket nem lehetséges röviden és tömören megfogalmazni. Szükséges lehet mindegyikhez magyarázatot füzni, enélkül óhatatlanul megválaszolhatatlan lesz azok számára a kérdés, akik nem ismerik a szakirodalmat a megfelelő mélységben. A magyarázattal viszont a kérdőív áttekinthetetlenné válik, ráadásul a kérdések túlzott mértékü egyszerüsítést vonnának magukkal, ami miatt az esetleges rejtett összefüggéseket nem lehetne feltárni.

Ez utóbbi zárja ki a megfigyelést és a tartalomelemzést (projektdokumentumok áttanulmányozását), hiszen ezekből kevesebb információt lehetne megtudni, vagyis a rejtett összefüggésekre nagy valószínüséggel nem derülne fény.

Ezzel szemben az interjúk során többet tudhat meg az interjúztató, mint a statisztikai elemzés vagy kérdőív révén. Ráadásul a válaszok függvényében az interjúztató tudja pontosítani a kérdést, ez pedig sokszor igen nagy fontossággal bír. További előnye, hogy a kutatási kérdéseimhez hasonló kérdésekre az interjúalanyok sokszor nem releváns véleményt mondhatnak a tények vagy a releváns vélemények helyett, amik az interjú során könnyen kiszürhetők és pontosíthatók. Az interjú hátrányai (nehéz kódolás, időígényesség) megfelelö tervezéssel kivédhetőek voltak, azaz a kutatás időbeli ütemezésének részletes megtervezésével és az interjúkérdések megfelelő összeállításával.

Mindezek alapján az interjú a legmegfelelőbb módszer.

Az interjú a kutatási kérdések megválaszolása (és a hipotézisek elfogadása/elvetése) érdekében négy kérdéskört kell tartalmaznia. Az első blokk során a projektvezető által ismert eszközök kerültek feltérképezésre, és az, hogy ezek közül melyiket használja a projektsiker elérése érdekében (figyelembe véve a hierarchikus modell hármas megbontását). A második blokkban a tacit és explicit tudás projektvezetési szemléletmódon belül aránya került feltérképezésre. A harmadik blokkban a projektvezető projektvezetési attitüdjét került azonosításra, és az, hogy ezek miként hatnak a projektsikerre (figyelembe véve a hierarchikus modell hármas megbontását). A negyedik blokkban pedig a személyiségjegyek projektvezetési szemléletmódra és a vezetési stílusra gyakorolt hatása került feltérképezésre. Ezek alapján a következő kérdések kerültek megfogalmazásra:

1. Kvalitatív/kvantitatív tudás hatása a projektsikerre 
a. Milyen projektvezetési eszközöket ismer?

b. Milyen projektvezetési eszközöket használ?

c. Milyen fontosabb érintettek szerepelnek a projektben?

d. Milyen módon sikerült elérni a sikeres projektjei esetén, hogy a projekteredményt elfogadják, a rájuk bízott feladatokat megcsinálják az érintettek?

e. Milyen módon sikerült elérni sikeres projektjei esetén, hogy a projekttulajdonosi szervezet által támasztott követelményeknek megfeleljen a projekteredmény?

f.Milyen módon sikerült biztosítani sikeres projektjei esetén, hogy a projektháromszög paramétereit elérjék?

2. Tacit/explicit tudás a szemléletmód esetén

a. Milyen jellegü végzettséggel/ projektvezetési képesítésekkel rendelkezik?

b. Milyen projektvezetési szemléletmód alapján vezeti a projekteket?

c. Milyen projektvezetési szemléletmód alapján alkalmazza a kvalitatív és kvantitatív projektvezetési eszközöket?

3. Szemléletmód hatása a projektsikerre

a. Milyen projektvezetési szemléletmód alapján vezeti a projekteket?

b. Ez a projektvezetési szemléletmód megítélése szerint milyen hatással van a kvantitatív és kvalitatív eszközök használatára?

c. Ez a projektvezetési szemléletmód milyen módon befolyásolja a projektháromszög szerinti siker elérését?

d. Ez a projektvezetési szemléletmód milyen módon befolyásolja a projekttulajdonosi szervezet elégedettségét?

e. $\quad$ Ez a projektvezetési szemléletmód milyen módon befolyásolja a fontosabb érintettek elégedettségét?

4. A személyiség hatása a szemléletmódra és a vezetési stílusra

a. Ön szerint milyen tényezők hatnak a projektvezetési szemléletmódra?

b. OÖn szerint milyen tényezők hatnak a vezetési stílusra?

c. Változtak-e a személyiségjegyei szakmai pályafutása során?

d. Amennyiben nemleges választ kapok a 4/c kérdésre, akkor: Miként tudná jellemezni magát, mindenképp kitérve az alábbi pontokra:

i. optimizmus,

ii. érzelmi intelligencia, 
iii. csapatépítő képesség

iv. bizalomépítő-képesség,

v. motiváló képesség,

vi. improvizáció.

e. Amennyiben nemleges választ kapok a 4/c kérdésre, akkor: Miként jellemezné a vezetési stílusát?

f.Amennyiben a 4/c kérdésre igenlő választ kapok, akkor miként tudná jellemezni magát a változás előtt és után, mindenképp kitérve az alábbi pontokra:

i. optimizmus,

ii. érzelmi intelligencia,

iii. csapatépítő képesség

iv. bizalomépítő-képesség,

v. motiváló képesség,

vi. improvizáció.

g. Amennyiben a 4/c kérdésre igenlő választ kapok, akkor: Miként jellemezné a vezetési stílusát változás előtt és után?

h. Ön szerint, ha változnának a személyiségjegyei, változna-e a projektvezetési szemléletmódja és a vezetési stílusa is?

A kutatás céljának eléréséhez kétlépcsős megközelítés került alkalmazásra: a szakirodalom feldolgozását és a gyakorlati kutatást.

A szakirodalom feldolgozása során a projektsikerhez, a sikerkritériumokhoz, a kritikus sikertényezőkhöz, a tudás típusához, a projektvezető tudásához, a vezetői stílushoz és a személyiségjegyekhez kapcsolódó irodalmak kerültek összegyüjtésre és elemzésre. Ennek következtében a projektsiker értékelésére legalkalmasabb modell (a hierarchikus modell), a projektvezető projektvezetési megközelítése, a vezetési stílusok és a személyiségjegyek kerültek azonosításra. Ezek alapján pedig az interjúkérdések kialakításra kerülhettek.

Az interjú - ahogy korábban említésre került - négy kérdéskörből tevődött össze. Az első kérdéskör során lehetőség nyílt a projektvezető tudásának azonosítására, amely öt lépésből tevődött össze. Az első elem a projektvezető által ismert eszközök feltérképezésére szolgált. Ugyanis az a projektvezető, aki nem rendelkezik megfelelő tudással, nem rendelkezhet projektvezetési szemléletmóddal sem (c.f. Cleland, 1994). A következő lépés során feltérképezésre kerültek a 
projektvezető által használt projektvezetési eszközök. Ennek célja az volt, hogy azonosításra kerüljön, milyen kvalitatív és kvantitatív eszközöket használ a projektvezető. Amennyiben a kvantitatív elemek dominálnak vagy a projektvezető fontosabbnak véli, akkor nagy esély mutatkozik az első hipotézis elfogadására. Ennek erősítésére (vagy cáfolására) szolgál az 1/d, 1/e, 1/f kérdés, azonban részletesebb megbontással. Ennek a kérdéscsoportnak a célja az előző, 1/b kérdés során kialakult álláspont megerősítése, azaz az első hipotézis elfogadása/elvetése. A kérdéscsoportnak (1d, 1/e, 1/f) az eredményei alapján a hierarchikus modell egyes sikerkritériumai eléréséhez szükséges kvalitatív és kvantitatív eszközök kerültek azonosításra a projektvezető válaszai függvényében. Természetesen előfordulhat, hogy a projektvezető nem a klasszikus projektvezetési eszközöket adja válaszként, azonban ezek kategorizálásra kerültek a szakirodalom alapján (c.f. Görög, 2013a, Project Management Institute, 2013). Megkérdezésre került továbbá még az is, hogy a projektben milyen érintettek szerepelnek. Ez a végső konklúziók kialakításában segíthet, hiszen amennyiben a projektvezető által elérhető érintettek száma limitált (különösen akkor, ha a projekttulajdonos sincs köztük), akkor általános következtetések nem fogalmazhatók meg. A kérdéskörön belül a függő változó a projektsiker adott aspektusa, míg a független változó a kvalitatív és kvantitatív eszközök voltak.

A második kérdéscsoport célja az volt, hogy azonosítani lehessen, hogy a tacit vagy explicit tudás használata dominál-e a projektvezető projektvezetési szemléletmódjában. Az első kérdés ebben a részben a projektvezető végzettségének és projektvezetői képesítésének azonosítására irányult. Ugyanis elképzelhető, hogy a végzettségnek hatása van arra, hogy milyen eszközöket használ. Bár a kutatásnak nem célja, hogy ennek hatását feltérképezze, azonban mindenképpen fontos támpont lehet. Egyrészt a projektvezetési képesítések ${ }^{44}$ biztosítják a megfelelő projektvezetési eszközök birtoklását (vö. 1/a kérdés), másrészt támpontot jelenthet a 4/a és 4/b kérdésnél . A második kérdés során azonosításra került a projektvezető projektvezetési szemléletmódja (ld. 4.1.1. fejezet). Ezt követően az, hogy a korábban említett kvalitatív és kvantitatív eszközket milyen módon alkalmazza. A kérdést sokszor pontosítani kellett, hogy az interjúalany szerint inkább tanulható vagy inkább elsajátítható-e (vö. tacit vs. explicit tudás). Ennek fényében azonosítani

${ }^{44}$ P1 PMP, Six Sigma tanúsítvány. 
lehetett, hogy ezek az eszközök alkalmazása során (az alkalmazott projektvezetési szemléletmód függvényében) a tacit vagy explicit tudás használata dominál-e. Ez alapján a második hipotézis elfogadható vagy elvethető.

A harmadik rész célja az volt, hogy a projektvezető projektvezetési szemléletmódjának hatása azonosításra kerüljön. A kutatás célja a hatás kimutatása volt, a mérték feltérképezése nem. Ennek fényében lettek kialakításva a kérdések. A 3/a és 3/b kérdésekre elvileg a korábbi részben választ lehetett kapni, azonban előfordulhatott, hogy a 3/c, 3/d és a 3/e kérdések függvényében pontosítani kellett. De amennyiben kellően mély és alapos választ adott az interjúalany a második részben, akkor erre a két kérdésre nem volt szükség, és az interjú során kihagyásra került. A következő három kérdés (3/c, 3/d, 3/e) rákérdez a projektvezetői szemlélet projektsikerre gyakorolt hatására. Azonban a válasz teljessége miatt a projektvezetőnek nem csak azt kellett megmondania, hogy szerinte gyakorol-e hatást a projektvezetői szemléletmód a projektsiker adott aspektusára (pozitívan vagy negatívan), hanem azt is, hogy miként. Ezáltal kiszürhetővé váltak a valótlan válaszok . Így ennek a három kérdésnek (3/c, 3/d, 3/e) alapján a harmadik hipotézis elfogadhatóvá vagy elvethetővé válik. A kérdéscsoport során a függő változó a projektsiker adott aspektusa volt, míg a független változó a szemléletmód.

A negyedik kérdéskör célja az volt, hogy a projektvezető személyiségjegyeinek a vezetési stílusra és projektvezetői szemléletmódjára gyakorolt hatását azonosítani lehessen. Ez két lépcsőből tevődött össze. Egyfelöl megkérdezésre került (a 4/a és a 4/b kérdés keretében), hogy az interjúalany szerint milyen tényezők vezettek a jelenlegi vezetési stílusának és projektvezetési szemléletmódjának kialakulásához. Itt kezdetben nem kapott segítséget az interjúalany. Azonban amennyiben a projektvezető nem tudott válaszolni erre, akkor támpontként felsorolásra került, hogy a személyiségjegy, a család, az oktatás vagy a vállalati kultúra gyakorolt-e hatást a két tényező kialakulására. Amennyiben a projektvezető a válaszai között nem említette a személyiségjegyeit, akkor meg lett kérdezve, hogy ez hatással van-e. A minél kisebb befolyásolás érdekében ez bele lett ágyazva a korábban említett három másik elem közé (amennyiben azokat nem említette). A vezetési stílushoz azonban szükség volt további megerősítésre, ez pedig az együttváltozás értékelése alapján történt. Megkérdezésre került, hogy változtak-e a személyiségjegyek (a projektvezetőnek meg lett mutatva a korábban azonosított 
öt+egyet). A változást leírhatta az interjúalany skálán vagy leírhatta szavakkal. Ha változtak a személyiségjegyei, akkor megkérdezésre került, hogy változott-e a vezetési stílusa, és ha igen, akkor hogyan. Amennyiben nem változott, akkor megkérdezésre került, hogy hogyan jellemezné a vezetési stílusát (külön figyelembe véve azt, hogy változott-e). Amennyiben felfedezhető az együttváltozás (vagy mindkettő statikussága esetén az együtt nem változás), akkor megerősítésre került a 4/b kérdés során adott válasz. Természetesen figyelembe kell azt venni, hogy könnyen a hamis korreláció csapdájába lehet esni, de ezt kiküszöböli a 4/b kérdés (és a 4/h is). A másik tényező, amit figyelembe kell venni az az, hogy elképzelhető, nem csak a személyiségjegyei hatottak a vezetési stílusra. Azonban a kutatásnak nem célja az összes, vezetési stílusra gyakorolt tényező feltárása, csakúgy, mint az sem, hogy melyik tényező gyakorolja a legnagyobb hatást rá. Végül - ellenőrző kérdésként - a 4/h kérdés feltevésre került. Így megállapítható, hogy a negyedik hipotézis elfogadása vagy elvetése több lépés alapján történik meg. A projektvezetői szemléletmódnál a 4/a kérdés képezte a kiindulási pontot, azaz amennyiben a projektvezető említette a személyiségjegyeit - és a 4/h kérdés ezt megerösítette akkor a hipotézis egyik fele elfogadásra került. A vezetési stílusnál a 4/b kérdés képezte a kiindulási pontot, azonban ebben az esetben kettős ellenőrzés került alkalmazásra. Azaz egyfelől vizsgálatra került az együttváltozás vagy együtt nem változás, továbbá a $4 / \mathrm{h}$ kérdés is segített kiszürni a hibás válaszokat vagy ellentmondásokat. Amennyiben ellentmondásra derült fény, akkor a válaszok újra átvizsgálásra/pontosításra kerültek. Ilyenre lehetett példa, hogy a projektvezető szerint a vezetési stílusra a személyiségjegyei hatást gyakorolnak, azonban a személyiségjegyeinek változása ellenére a vezetési stílusa ugyanolyan maradt. Mindezek fényében kijelenthető, hogy a negyedik hipotézis az interjú negyedik része alapján elfogadható vagy elvethető. A kérdéscsoporton belül a függő változó a projektvezetési szemléletmód és a vezetési stílus volt, míg a független változót a személyiségjegyek adták.

\subsection{A kutatás alapjául szolgáló minta}

A kutatás alapját az infókommunikációs (továbbiakban ICT) szektorban jelen lévő multinacionális vállalatok hazai leányvállalatai adták. A multinacionális 
karakterisztikákra a magyarországi (főként projektvezetési) sajátosságok hatásának csökkentése érdekében volt szükség (pl. így a kompetencia nagyobb súllyal esik latba a projektcsapat összeállítása során). A kutatás során 5 nemzetközi vállalat leányvállalat lett kiválasztva szakértői becslés alapján, olyanok, amelyek a piac meghatározó szereplői. Nevüket azonban titoktartási okokból nem lehet felfedni.

Ahogy korábban bemutatásra került, a kutatás során félig strukturált mélyinterjúk képezték a gyakorlati rész alapját. Egy-egy interjú összességében nettó 45-70 percig tartott. Ennek keretében választ lehetett kapni a korábban említett kutatási kérdésekre, és igazolni vagy elvetni a hipotéziseket.

A kutatás során a populációt, azaz a minta alapját az 5 vállalat projektmenedzserei jelentették. Amennyiben a vállalatnak több szervezeti egysége is volt eltérő funkciókkal (pl. rendszerfejlesztés, új díjcsomag piaci bevezetése), akkor az IT-hez legközelebb álló osztály került kiválasztásra. Természetesen elöfordulhat, hogy az IT osztály együttmüködjön egy közös projekt esetén más osztályokkal (pl. új díjcsomag bevezetése esetén a számítógépes háttértámogatás megteremtése), azonban ilyenkor is azok a projektvezetők kerültek megkérdezésre, amelyek az IThez legközelebb álló osztályhoz tartoznak. Belölük lett kiválasztva a helyi projektiroda (továbbiakban PMO) vagy egy elismert projektvezető segítségével az a 31 projektvezető, akik a mintát jelentették. A mintavétel során a PMO vagy a projektvezető mediátori segítségét felhasználva véletlen mintavételi eljárás került alkalmazásra. Ugyanis a projektvezető vagy a PMO kiküldött egy körlevelet a projektvezetőknek (vagy személyesen megkérdezte), hogy ki az, akinek ideje és kedve lenne részt venni a kutatásban. A jelentkező projektvezetők képezték a mintát. Természetesen az idő és kedv jelentős korlátot jelentett a mintavétel során, azonban a véletlenséget ez nem befolyásolta (hiszen nem lett irányított megkérdezés), „csupán” a mintaelemszámot. Amennyiben a mintaelemszám elégtelennek tűnt, akkor újra megkérdezésre kerültek a projektvezetők. A minta elemszámát megbontva vállalatonként a 7 táblázat tartalmazza:

7. táblázat: A mintaelemszám megbontva vállalat szerint

\begin{tabular}{|l|l|l|}
\hline Vállalat & Interjúalanyok száma & Alpopuláció mérete \\
\hline Vállalat 1 & 11 & $50+$ \\
\hline Vállalat 2 & 5 & $20+$ \\
\hline
\end{tabular}




\begin{tabular}{|l|l|l|}
\hline Vállalat 3 & 7 & 8 (adott részleg létszáma) \\
\hline Vállalat 4 & 2 & 4 \\
\hline Vállalat 5 & 6 & 50 körül \\
\hline
\end{tabular}

Forrás: saját szerkesztés

A mintaelemszám látszólag kevésnek tünhet az első, a második és az ötödik vállalat esetén. Azonban a projektvezetők tudása és a kezdeményezett projektek kvázi homogén jellege miatt elégségesnek tekinthetö. Emellett az adott cégen belül a projektvezetők - köszönhetően a vállalati tréningeknek, alkalmazott közös keretrendszernek és eszközöknek - nagyjából homogén tudással rendelkeznek projektvezetői technikákat és általános projektvezetési módszertant tekintve, ráadásul egy-egy vállalaton belül a projektvezetési kultúra is megegyezik. Ezek alapján kijelenthető, hogy a minta elemszáma elégséges ahhoz, hogy releváns következtetéseket lehessen levonni a vállalatokra és azokra, amik hasonló jellemzőkkel bírnak.

\subsubsection{Az iparág jellemzője}

Az ICT szektor alapjában véve rendkívül turbulens, gyorsan változó, innovatív, tudásintenzív és jellemzője a rövid technológiai életciklus (c.f. Blaskovics, 2014). Ebből fakadóan nagy hangsúly helyeződik a dolgozókra és a dolgozók tudásának kiaknázására (különösen akkor, ha valamilyen teljesen új ICT alkalmazás kerül kialakításra). Az iparági jellemzők természetesen hatással lehetnek a vezetési stílusra és/vagy projektvezetési szemléletmódra, azonban ezek hatásának elemzése nem képezi a disszertáció részét. Megemlítése azért fontos, mert a következtetések csak hasonló jellemzőkkel bíró iparágban tevékenykedő vállalatok projektvezetőire lehetnek relevánsak.

\subsubsection{A vállalatok jellemzője}

A projektvezetők karakterisztikáira két tényező lehet hatással az előzetes vizsgálatok alapján, egyfelől az alkalmazott projektvezetési módszertan, másfelől pedig a vállalati kultúra. Az első mindegyik esetében ugyanaz, ugyanis mindegyik cég az agilis projektvezetési módszertan egészét vagy részét próbálja alkalmazni. Természetesen a vállalatok eltérő szinten vannak az alkalmazás során, a 4. és 5 . magas szinten alkalmazza, míg az első három még sok elemet vesz át a klasszikus 
waterfall projektvezetési módszertanból, és inkább csak bizonyos részeket emel át az agilis módszertanból. A másik fontos jellemző a vállalati kultúra. A harmadik, a negyedik és ötödik vállalat skandináv kultúrát adaptált, méghozzá igen magas szinten, ezért a dolgozók elégedettsége és a tudásuk minél magasabb szintü kihasználása fontos a vállalatok számára. A maradék kettő vállalat (bár külföldi tulajdonban van) esetén kevéssé érződik a nemzetközi kultúra, leginkább az alkalmazott projektvezetési módszertanban mutatkozik meg, hiszen az anyacég testreszabott projektvezetési eljárása (általában PMBOK alapú) jelenti az alapot a projektek vezetése során.

Összességében megállapítható, hogy a vállalati kultúra markáns hatást gyakorol a harmadik, a negyedik és ötödik vállalat esetén, míg közepes mértéküt a többi esetén. Az alkalmazott projektvezetési módszert tekintve a negyedik és ötödik vállalat agilisnak tekinthető, míg az első három inkább klasszikusnak agilis elemekkel átszőve. Ezek is (hasonlóan az iparág jellemzőihez) óhatatlanul hatnak a projektvezetőre, még akkor is, ha a projektvezető olyan aktív szereplő, aki némiképp tudja csökkenteni az iparági és szervezeti hatásokat.

\subsubsection{A kutatás korlátai}

Mivel a kutatás mintáját az ICT szektorban jelen lévő multinacionális vállalatok hazai leányvállalatai adták, ezért a kutatás óhatatlanul jelentős limitációkkal bír. A kutatás eredményei csak azokra a vállalatok projektvezetőire lehetnek érvényesek, amelyek hasonló karakterisztikákkal rendelkező vállalatnál dolgozik, mint az öt vállalat egyike, és az ICT szektorhoz hasonló iparágban tevékenykedik. Könnyen belátható, hogy a klasszikus építöipari projektek esetén az alkalmazottaknak jóval kisebb szerepük van, mint egy rendszerfejlesztés esetén, ráadásul a szükséges tudás mértéke is könnyebben megtanulható (természetesen kivételek itt is vannak, hiszen a mérnökök komoly és nehezen elsajátítható tudással rendelkeznek). Ezért kutatásomnak nem célja az általánosítás, azaz minden iparágra érvényes konklúziók levonása. Azonban sokkal hasznosabb, ha egy adott iparágat részletesebben és több mintát felhasználva elemzek, mint az, ha általánosabb, de kevésbé alaposabb vizsgálat révén igyekszem más ágazatokra is kiterjeszteni a vizsgálatot. 


\subsection{A kutatás eredményei}

A kutatás során a korábban megfogalmazott négy kutatási kérdésre megválaszoláas jelentette a fó célt, illetve a hipotézisek elfogadása vagy elvetése. Ehhez a korábban bemutatott módon, mélyinterjúk segítségével kerülhetett sor. A kutatás - jellegéböl fakadóan - négy, egymással némi átfedésben álló kérdéskörre osztható, aminek az elemei a következők:

1. A projektvezető tudásának feltérképezése. Ennek keretében sor került a projektvezető által ismert és alkalmazott eszközök feltérképezésére, a projektvezető által vezetett projektek föbb érintettjeinek azonosítására és arra, hogy a három sikerkritérium szerint értelmezett sikeresség elérése során kvalitatív vagy kvantitatív eszközök dominálnak-e. Ehhez óhatatlanul szükséges volt feltérképezni azt, hogy milyen eszközöket használ a projektvezető a projektsiker elősegítése érdekében.

2. A projektvezető által alkalmazott projektvezetési szemlélet azonosítása, valamint az, hogy ebben a szemléletben a tacit vagy explicit tudás használata dominál-e.

3. A korábban azonosított projektvezetési szemléletmód a hierarchikus modell szerint értelmezett projektsikerre gyakorolt hatásának azonosítása (Görög, 2013a) .

4. A személyiségjegyek vezetési stílusra és projektvezetési szemléletmódra gyakorolt hatásának azonosítása. Ahogy korábban bemutatásra került, a szemléletmódra gyakorolt hatás esetén kétlépcsős, míg a vezetési stílus esetén háromlépcsős módszer került alkalmazása.

\subsubsection{A projektvezető tudásának feltérképezés}

A kutatás első fázisa a projektvezető tudásának feltérképezése volt, valamint az, hogy milyen eszközökkel képes biztosítani a hierarchikus modell szerint értelmezett projektsikert teljesülését (Görög, 2013a), azaz elősegíteni a projektháromszög, a projekttulajdonosi szervezet elégedettsége és az érintettek elégedettsége szerinti sikeresség teljesülését. A fókusz az 1/d, 1/e, 1/f kérdéscsoport kapcsán az alkalmazott eszközök milyenségére helyezödött, azaz kvantitatív vagy 
kvalitatív eszközök járulnak-e nagyobb mértékben a projektsiker mindhárom szintjéhez hozzá.

A második fázis első lépése a projektvezető tudásának feltérképezésére irányult. Amennyiben a projektvezető birtokában van a megfelelő ismeretnek, akkor képezheti az alapot a későbbi vizsgálatokra, hiszen ahogy az 4.1.1. fejezetben megállapításra került, a projektvezető csak akkor rendelkezhet projektvezetési szemléletmóddal, ha a megfelelő tudás birtokában van (vö. Cleland, 1994). Figyelembe kellett természetesen azt is venni, hogy a projektvezető a vezetése alatt kevesebb eszközt használ, mint amennyit ismer (pl. az alkalmazott módszertan miatt), ezért óhatatlanul szükséges mindkettő feltérképezése.

Az elvárt tudás igen szerteágazó tud lenni köszönhetően a projekt és a projektvezetés értelmezésének fejlődése miatt (vö. Görög, 2013a, Project Management Institute 2010), így a válaszok során a következőt kerültek az elemzés fókuszába:

- a teljesítés megfelelő tervezése,

- megfelelö nyomon követés/kontroll,

• érintettek megfelelő kezelése,

- optimalizálás (amennyiben a válaszadó a change managementet említette, akkor természetesen az is elfogadásra került, még akkor is, ha a kettő nem teljes mértékben kezelhető szinonimaként).

A tervezés óhatatlanul komplex, több projektvezetési eszközből áll össze, hiszen magában foglalja a tevékenységstruktúra kialakítását, időtervet, erőforrástervet, költségtervet, kockázatmenedzsmentet, érintett elemzést és projektbehatárolást ${ }^{45}$. Amennyiben a projektvezető említette a tervezést, akkor az is elfogadásra került, nem volt szükséges a mind a hét megnevezésére, azonban néhány projektvezető igen részletesen jellemezte tudását. Belátható, hogy ezek inkább tevékenységek, semmint projektvezetési eszközök, azonban az eszközök világosan következnek a tevékenységekből (pl. időtervezés esetén a GANTT-ábra), így ezek részletes taglalása elhagyható (vö. Görög, 2013a). Természetesen elfogadásra került az is, ha a projektvezető (saját bevallása szerint) ismer valamilyen projektvezetési

\footnotetext{
${ }^{45}$ A tervezésbe természetesen még egyéb tényezőket is bele lehetne érteni (pl. a kontroll során alkalmazott normák kialakítása vagy a kommunikációs terv elkészítése), azonban a föbb összetevőket ezek jelentik (vö. Görög, 2013a).
} 
módszertant, keretrendszert vagy ajánlást. Ilyenre példa a PMBOK vagy ennek valamilyen vállalati adaptációja, a Six Sigma projektvezetői leképeződése, IPMA minősítés vagy a PRINCE2. Az agilis projektvezetési módszertan akkor volt elfogadottnak tekinthető, ha ehhez megfelelő eszközök is társultak (mint pl. időterv esetén a GANTT-ábra). Ezek alapján a projektvezetők a következő ismerettel és alkalmazott tudással a 8 . táblázat szerint rendelkeznek:

8. táblázat: A projektvezetők ismert és alkalmazott eszközei/tevékenységek

\begin{tabular}{|c|c|c|c|}
\hline & & Ismert eszközök & Alkalmazott eszközök \\
\hline \multirow{9}{*}{ 1. vállalat } & 1. interjúalany & $\begin{array}{l}\text { tervezés, } \\
\text { kontroll, } \\
\text { érintettek elemzése, } \\
\text { change management }\end{array}$ & $\begin{array}{l}\text { tervezés, } \\
\text { kontroll, } \\
\text { érintettek elemzése, } \\
\text { change management }\end{array}$ \\
\hline & 2. interjúalany & $\begin{array}{l}\text { tervezés, } \\
\text { kontroll, } \\
\text { change management }\end{array}$ & $\begin{array}{l}\text { tervezés, } \\
\text { kontroll, } \\
\text { change management }\end{array}$ \\
\hline & 3. interjúalany & $\begin{array}{l}\text { klasszikus értelemben } \\
\text { vettek közül egyiket sem }\end{array}$ & $\begin{array}{l}\text { ad hoc eszközök (érintettek } \\
\text { kezelése, optimalizálás) }\end{array}$ \\
\hline & 4. interjúalany & $\begin{array}{l}\text { tervezés, } \\
\text { kontroll, } \\
\text { érintettek elemzése, } \\
\text { change management }\end{array}$ & $\begin{array}{l}\text { tervezés, } \\
\text { kontroll, } \\
\text { érintettek elemzése, } \\
\text { change management }\end{array}$ \\
\hline & 5. interjúalany & $\begin{array}{l}\text { tervezés, } \\
\text { kontroll, } \\
\text { érintettek elemzése, } \\
\text { change management }\end{array}$ & $\begin{array}{l}\text { tervezés, } \\
\text { kontroll, } \\
\text { érintettek elemzése, } \\
\text { change management }\end{array}$ \\
\hline & 6. interjúalany & PRINCE, PMBOK & $\begin{array}{l}\text { tervezés, } \\
\text { kontroll, } \\
\text { change management }\end{array}$ \\
\hline & 7. interjúalany & PMBOK & $\begin{array}{l}\text { tervezés, } \\
\text { kontroll, } \\
\text { change management }\end{array}$ \\
\hline & 8. interjúalany & PMBOK & $\begin{array}{l}\text { tervezés, } \\
\text { kontroll, } \\
\text { érintettek elemzése, } \\
\text { change management }\end{array}$ \\
\hline & 9. interjúalany & IPMA tréning & $\begin{array}{l}\text { tervezés, } \\
\text { kontroll, } \\
\text { change management }\end{array}$ \\
\hline
\end{tabular}




\begin{tabular}{|c|c|c|c|}
\hline & $\begin{array}{l}10 . \\
\text { interjúalany }\end{array}$ & $\begin{array}{l}\text { agilis, waterfall } \\
\text { megközelítések }\end{array}$ & $\begin{array}{l}\text { tervezés, } \\
\text { kontroll, } \\
\text { érintettek elemzése, } \\
\text { change management }\end{array}$ \\
\hline & $\begin{array}{l}11 . \\
\text { interjúalany }\end{array}$ & PMBOK & $\begin{array}{l}\text { tervezés, } \\
\text { kontroll, } \\
\text { érintettek elemzése, } \\
\text { change management }\end{array}$ \\
\hline \multirow{5}{*}{ 2. vállalat } & $\begin{array}{l}12 . \\
\text { interjúalany }\end{array}$ & Six Sigma & $\begin{array}{l}\text { tervezés, } \\
\text { kontroll, } \\
\text { érintettek elemzése, } \\
\text { change management }\end{array}$ \\
\hline & $\begin{array}{l}13 . \\
\text { interjúalany }\end{array}$ & PMBOK & $\begin{array}{l}\text { tervezés, } \\
\text { kontroll, } \\
\text { érintettek elemzése, } \\
\text { change management }\end{array}$ \\
\hline & $\begin{array}{l}14 . \\
\text { interjúalany }\end{array}$ & PMBOK & $\begin{array}{l}\text { tervezés, } \\
\text { kontroll, } \\
\text { érintettek elemzése, } \\
\text { change management }\end{array}$ \\
\hline & $\begin{array}{l}15 . \\
\text { interjúalany }\end{array}$ & PMBOK & $\begin{array}{l}\text { tervezés, } \\
\text { kontroll, } \\
\text { érintettek elemzése, } \\
\text { change management }\end{array}$ \\
\hline & $\begin{array}{l}16 . \\
\text { interjúalany }\end{array}$ & PMBOK, IPMA, PRINCE2 & $\begin{array}{l}\text { tervezés, } \\
\text { kontroll, } \\
\text { érintettek elemzése, } \\
\text { change management }\end{array}$ \\
\hline \multirow{4}{*}{ 3. vállalat } & $\begin{array}{l}17 . \\
\text { interjúalany }\end{array}$ & semmilyet & semmilyet \\
\hline & $\begin{array}{l}18 . \\
\text { interjúalany }\end{array}$ & PMBOK, PRINCE2, agilis & $\begin{array}{l}\text { tervezés, } \\
\text { kontroll, } \\
\text { érintettek elemzése, } \\
\text { change management }\end{array}$ \\
\hline & $\begin{array}{l}19 . \\
\text { interjúalany }\end{array}$ & PMBOK & $\begin{array}{l}\text { tervezés, } \\
\text { kontroll, } \\
\text { érintettek elemzése, } \\
\text { change management }\end{array}$ \\
\hline & $\begin{array}{l}20 . \\
\text { interjúalany }\end{array}$ & PMBOK & $\begin{array}{l}\text { tervezés, } \\
\text { kontroll, } \\
\text { érintettek elemzése, } \\
\text { change management }\end{array}$ \\
\hline
\end{tabular}




\begin{tabular}{|c|c|c|c|}
\hline & $\begin{array}{l}21 . \\
\text { interjúalany }\end{array}$ & PMBOK, Six Sigma & $\begin{array}{l}\text { tervezés, } \\
\text { kontroll, } \\
\text { érintettek elemzése, } \\
\text { change management }\end{array}$ \\
\hline & $\begin{array}{l}22 . \\
\text { interjúalany }\end{array}$ & $\begin{array}{l}\text { tervezés, } \\
\text { kontroll, } \\
\text { érintettek elemzése, } \\
\text { change management }\end{array}$ & $\begin{array}{l}\text { tervezés, } \\
\text { kontroll, } \\
\text { érintettek elemzése, } \\
\text { change management }\end{array}$ \\
\hline & $\begin{array}{l}23 . \\
\text { interjúalany }\end{array}$ & PMBOK & $\begin{array}{l}\text { tervezés, } \\
\text { kontroll, } \\
\text { érintettek elemzése, } \\
\text { change management }\end{array}$ \\
\hline \multirow[b]{2}{*}{ 4. vállalat } & \begin{tabular}{|l}
4. \\
interjúalany
\end{tabular} & $\begin{array}{l}\text { erőforrástervezés, } \\
\text { kontroll }\end{array}$ & $\begin{array}{l}\text { erőforrástervezés, } \\
\text { kontroll }\end{array}$ \\
\hline & $\begin{array}{l}25 . \\
\text { interjúalany }\end{array}$ & PMBOK & $\begin{array}{l}\text { tervezés, } \\
\text { kontroll, } \\
\text { change management }\end{array}$ \\
\hline \multirow{6}{*}{ 5. vállalat } & $\begin{array}{l}26 . \\
\text { interjúalany }\end{array}$ & $\begin{array}{l}\text { PMBOK, agilis } \\
\text { megközelítés }\end{array}$ & $\begin{array}{l}\text { tervezés, } \\
\text { kontroll, } \\
\text { érintettek elemzése, } \\
\text { change management }\end{array}$ \\
\hline & $\begin{array}{l}27 . \\
\text { interjúalany }\end{array}$ & $\begin{array}{l}\text { PMBOK, agilis } \\
\text { megközelítés }\end{array}$ & $\begin{array}{l}\text { tervezés, } \\
\text { kontroll, } \\
\text { érintettek elemzése, } \\
\text { change management }\end{array}$ \\
\hline & $\begin{array}{l}28 . \\
\text { interjúalany }\end{array}$ & $\begin{array}{l}\text { PMBOK, agilis } \\
\text { megközelítés }\end{array}$ & $\begin{array}{l}\text { tervezés, } \\
\text { kontroll, } \\
\text { érintettek elemzése, } \\
\text { change management }\end{array}$ \\
\hline & $\begin{array}{l}29 . \\
\text { interjúalany }\end{array}$ & $\begin{array}{l}\text { PMBOK, agilis } \\
\text { megközelítés }\end{array}$ & $\begin{array}{l}\text { tervezés, } \\
\text { kontroll, } \\
\text { érintettek elemzése, } \\
\text { change management }\end{array}$ \\
\hline & $\begin{array}{l}30 . \\
\text { interjúalany }\end{array}$ & $\begin{array}{l}\text { PMBOK, agilis } \\
\text { megközelítés }\end{array}$ & $\begin{array}{l}\text { tervezés, } \\
\text { kontroll, } \\
\text { érintettek elemzése, } \\
\text { change management }\end{array}$ \\
\hline & $\begin{array}{l}31 . \\
\text { interjúalany }\end{array}$ & $\begin{array}{l}\text { PMBOK, agilis } \\
\text { megközelítés }\end{array}$ & $\begin{array}{l}\text { tervezés, } \\
\text { kontroll, } \\
\text { érintettek elemzése, } \\
\text { change management }\end{array}$ \\
\hline
\end{tabular}

Forrás: saját szerkesztés 
Mindezek alapján megállapítható, hogy az interjúalanyok közül a 3. és a 17. nem képezheti a minta részét, míg a 24. eredményei esetén figyelembe kell venni, hogy az általa ismert eszközök mennyisége korlátozott (köszönhetően a tapasztalat és képzés hiányának). Azonban a 24. interjúalany eredményeit mindenképp figyelembe kell venni a későbbiek során, hiszen alapvető tudással rendelkezik. A 3. projektvezető nem tanult ilyen eszközöket, ebböl fakadóan inkább tapasztalat alapján használja azokat, így a klasszikus értelemben vett projektvezetési szemléletmód nem alakulhatott ki benne. Azonban érdekes összevetésre adhat alapot, azaz meg lehet vizsgálni egy későbbi kutatás során, hogy az elsajátított projektvezetési eszközök miként hathatnak a szemléletmódra. A 17. interjúalany pozíciójából fakadóan nem vezet projekteket (inkább szponzor vagy projektfelügyelö-bizottsági szerepkört képvisel egy-egy projekt során), ezért a válaszai szintén nem tekinthetők relevánsnak a kutatás során. Azonban szükséges hangsúlyozni, hogy a 17. interjúalany válaszai is igen értékesek lehetnek, amiket fel lehet használni egy másik kutatás során, hiszen a projekteket eggyel magasabb szintről vizsgálja.

Megállapítható tehát, hogy a projektvezetői tudást figyelembe véve a kutatás alapját a 9. táblázat szerinti minta jelenti:

9. táblázat: A végső mintaelemszám megbontva vállalatok szerint

\begin{tabular}{|c|c|c|c|c|}
\hline Vállalat & $\begin{array}{l}\text { Összes } \\
\text { interjúalany } \\
\text { száma }\end{array}$ & $\begin{array}{l}\text { Nem } \\
\text { megfelelő } \\
\text { tudással } \\
\text { rendelkező } \\
\text { interjúalanyo } \\
\text { k száma }\end{array}$ & $\begin{array}{l}\text { Elfogadható } \\
\text { tudással } \\
\text { rendelkező } \\
\text { interjúalanyok } \\
\text { száma }\end{array}$ & $\begin{array}{l}\text { Megfelelő } \\
\text { tudással } \\
\text { rendelkező } \\
\text { interjúalanyok } \\
\text { száma }\end{array}$ \\
\hline Vállalat 1 & 11 & 1 & 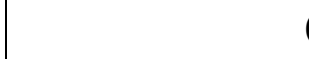 & 10 \\
\hline Vállalat 2 & 5 & 0 & 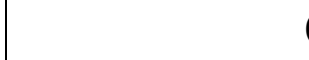 & 5 \\
\hline Vállalat 3 & 7 & 1 & 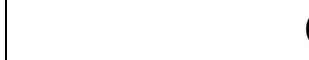 & 6 \\
\hline Vállalat 4 & 2 & 0 & 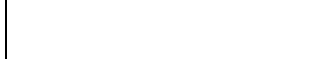 & 1 \\
\hline Vállalat 5 & 6 & 0 & 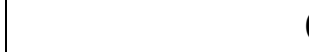 & 6 \\
\hline
\end{tabular}

Forrás: saját szerkesztés 
Ezt követően azon érintettek kerültek feltérképezésre, akikkel a projektvezető kapcsolatba kerül . Ennek szükségességét az interjú az 1/e és 1/f kérdése indokolja. Ugyanis amennyiben pl. nem kerül kapcsolatba a vevővel vagy a végfelhasználókkal, akkor az alkalmazott eszközök óhatatlanul korlátozottan kerülnek használatra (pl. a kommunikáció révén használandó eszközök tartalma változhat). A válaszok során a következő főbb érintettek azonosítására volt szükség:

- projektcsapat,

- egyes osztályok vezetői (ők adják a projekthez az erőforrásokat, illetve bizonyos esetben követelményeket szabnak a projekteet illetően - utóbbira lehet példa egy jogszabály esetén a jogi osztály szerepe),

- projektszponzor (szerepe a projekt támogatottságának növelése és/vagy a szükséges erőforrások előteremtésének megkönnyítése),

- projektgazda//projektigazgató ${ }^{46}$ (szerepe a vevő igényeivel való összhang megteremtése),

• beszállítók

• projekttulajdonosi szervezet (vevö),

•végfelhasználók.

Természetesen előfordulhat, hogy bizonyos érintettek nem vesznek részt a projektben (pl. a szponzor vagy a projektgazda), azonban ezt a projekt jellege is befolyásolhatja, hiszen könnyen elöfordulhat, hogy kettő vagy több szerepkör összevonódik (pl. a projektgazda és egy osztálynak a vezetője). Elöfordulhat az is, hogy valakivel nem áll direkten kapcsolatba a projektvezetö, azonban indirekten igen. Ilyenre lehet példa, ha a projekttulajdonosi szervezettel való kapcsolattartást más osztály végzi. Erre lehet példát találni a 3., 4. és 5. vállalat esetén. Azonban ilyenkor is megjelenik mint érintett, hiszen az igényeik direkten leképeződnek a projektben egy mediátor szereplö által. Továbbá szükséges megemlíteni, hogy ennél több érintettet is lehetne azonosítani, azonban ők nem jelentősek, hiszen az érdekeik megjelennek egyéb módon a projekteredményben (pl. a szakhatóságok). A projektcsapat mint érintett kiemelt szerepét (projektsiker szempontjából) az agilis projektvezetési eljárás és a vállalati kultúra indokolja. Ugyanis az agilis projektvezetési eljárás során (vö. Aljaz, 2013) a projektcsapat elégedettsége

\footnotetext{
${ }^{46}$ Bár a szakirodalom szerint ez a kettő nem kezelhető szinonimaként (vö. Görög, 2013a), azonban az interjúk során a kettő hasonló szerepkört tölt be, így megkülönböztetésük nem indokolt.
} 
felértékelődik, csakúgy, mint a skandináv vállalati kultúrával rendelkező vállalatok esetén (3., 4., 5. vállalat).

A válaszok alapján a következő érintettek kerültek azonosításra (zárójelben az szerepel, hogy hány projektvezető említette):

10. táblázat: Azonosított érintettek

\begin{tabular}{|c|c|c|c|}
\hline & $\begin{array}{l}\text { Érintettek, akikkel } \\
\text { kapcsolatba kerülnek }\end{array}$ & $\begin{array}{l}\text { Fontos érintettek, } \\
\text { akikkel ritkán kerülnek } \\
\text { kapcsolatba }\end{array}$ & $\begin{array}{l}\text { Fontos } \\
\text { érintettek, } \\
\text { akikkel nem } \\
\text { kerülnek } \\
\text { kapcsolatba }\end{array}$ \\
\hline 1. vállalat & $\begin{array}{l}\text { projektcsapat }(10), \\
\text { projektszponzor }(10), \\
\text { projektgazda/projektigazgató } \\
(10), \\
\text { beszállítók }(10), \\
\text { projekttulajdonosi szervezet } \\
\text { (vevő) }(10), \\
\text { végfelhasználók }(6)\end{array}$ & $\begin{array}{l}\text { egyes osztályok vezetői } \\
\text { (1) }\end{array}$ & - \\
\hline 2. vállalat & $\begin{array}{l}\text { projektcsapat (5), } \\
\text { egyes osztályok vezetői (5) } \\
\text { projektszponzor (5), } \\
\text { projektgazda/projektigazgató } \\
(5), \\
\text { beszállítók (5), } \\
\text { projekttulajdonosi szervezet } \\
\text { (vevő) (5), } \\
\text { végfelhasználók (4) } \\
\end{array}$ & - & - \\
\hline 3. vállalat & $\begin{array}{l}\text { projektcsapat (6), } \\
\text { egyes osztályok vezetői (6) } \\
\text { projektszponzor (6), } \\
\text { projektgazda/projektigazgató } \\
(6), \\
\text { beszállítók (6), } \\
\text { projekttulajdonosi szervezet } \\
\text { (vevö) (6), } \\
\text { végfelhasználók (4) }\end{array}$ & - & - \\
\hline 4. vállalat & $\begin{array}{l}\text { projektcsapat (2), } \\
\text { egyes osztályok vezetői (2), } \\
\text { projektgazda (2), } \\
\text { projekttulajdonosi szervezet } \\
(2)\end{array}$ & beszállítók (1) & $\begin{array}{l}\text { projektszponzor } \\
(2) \text {, } \\
\text { végfelhasználók } \\
(2)\end{array}$ \\
\hline
\end{tabular}




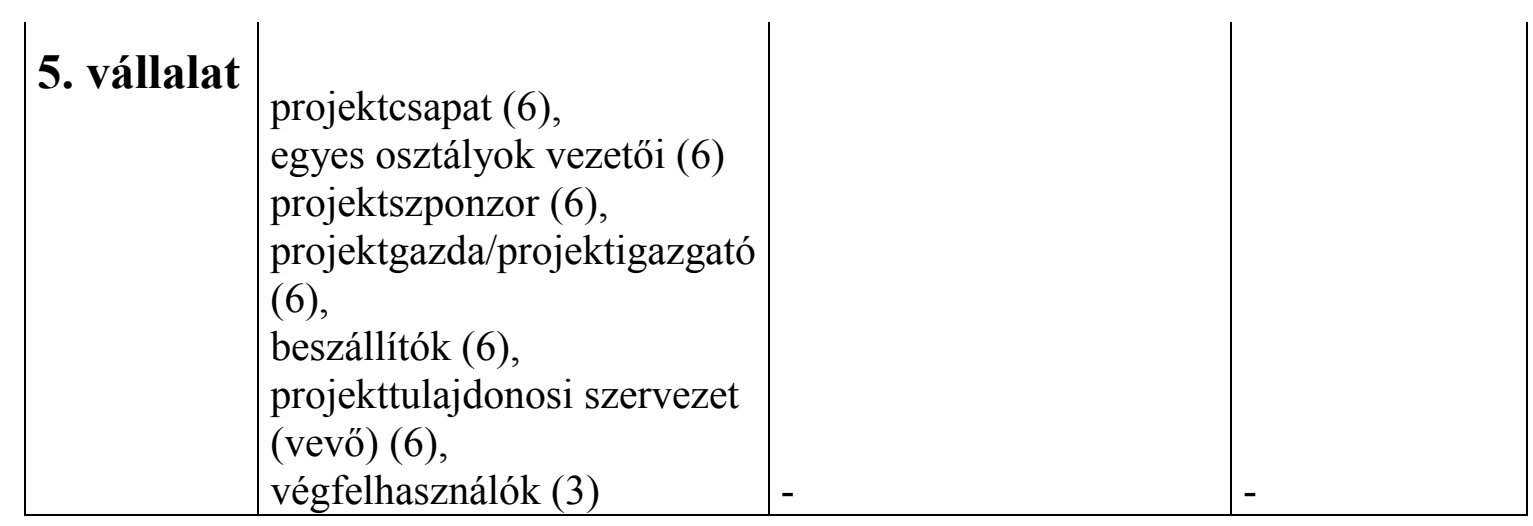

Forrás: saját szerkesztés

Mindezek alapján megállapítható, hogy mindegyik vállalat projektvezetői relevánsak az 1/d, 1/f, 1/e kérdés megválaszolásában, azaz annak megválaszolásában, hogy a hierarchikus modell szerinti projektsikert milyen eszközökkel érik el a projektvezetök. A válaszok alapján azonban négy körülményt figyelembe kell venni. A 4. vállalat esetén a végfelhasználói elégedettség nem jelenhet meg a kapcsolat és így a ráhatás hiánya miatt, esetükben a projektcsapat, az egyes osztályok vezetői, a projektgazda és némiképp a beszállítók jelentik az érintettek elégedettségét. Továbbá meg kell említeni, hogy a projektszponzor és a projektgazda elégedettsége nagymértékben összefügg a projekttulajdonosi szervezet elégedettségével, hiszen az utóbbi fő szempontja ennek az elégedettségnek megteremtése, míg az elöbbi (köszönhetően annak, hogy a vállalat hierarchia magasabb szintjéről kerül a projektbe) akkor válik elégedetté, ha sikerül eladni a projekteredményt. Harmadikként meg kell említeni, hogy az interjú arra nem tért ki, hogy mely' szerepkörök összevontak (pl. osztályok vezetői és projektgazda). Azonban a megbontás nem befolyásolná a kutatást, hiszen ilyenkor az érdekeiket mindenképpen vizsgálni kell, és ha a szerepkörük kettős, akkor többféle érdek is megjelenik. Azaz a hangsúly ennek során nem az érintettek mint önálló entitások feltérképezésére irányult, hanem az érintettekre mint szerepkörökre. Negyedikként pedig meg említeni azt a tényt, hogy a projektcsapat kialakítása (leszámítva a tervezés során meghatározott erőforrásigényt és a megfelelő kommunikációt) nem tartozik a projektvezető felelősségi körébe. Ez annak köszönhető, hogy mindegyik cég mátrixstruktúrában dolgozik (általában gyenge mátrixban), ráadásul vállalati belső szabályozás köti öket ezen folyamat során, így szerepük inkább elszenvedő, semmint aktív alakító, így ilyen irányú tudások szükségessége kevésbé jelentős. Továbbá a szerződéskötés és a megfelelő projektteljesítési stratégia kialakítása 
(elszámolási mód, szerződéstípus, előminősítés és versenyeztetés) sem tartozik a feladataik közé, hiszen ezt külön osztály végzi. A szerződéssel kapcsolatos felelősségi körük kimerül a projekteredmény részletes leírásában, azonban ez projekttudás szempontjából a tervezéshez kapcsolódik, nem pedig a szerződéskötéshez.

A következő lépés a projektvezetők által használt projektsikert elösegítő eszközök alkalmazása volt. A kutatás során a csoportosítás alapját az jelentette, hogy kvalitatív vagy kvantitatív eszközök tartoznak-e többségben egy adott tevékenységbe (összhangban a kutatási kérdéssel). Ahogy az 4.2-es fejezetben bemutatásra került, kvantitatív eszközök azok, amiknél számszerüsített formában kerül kifejezésre az eszköz eredménye. Ilyen példa az időtervezés. Míg kvalitatív eszközök azok, amelyeknek használata során nem születik számszerü eredmény. Ilyenre példa a kommunikáció. Természetesen előfordulhat, hogy a projektvezető több kvantitatív eszközt alkalmaz, azonban ez még nem feltétlen jelenti azt, hogy a számosságbeli többség magával vonja a nagyobb mértékü hozzájárulást is. Kvantitatív eszközt tartalmazó tevékenységnek a tervezést és a kontrollt lehetett tekinteni, hiszen ezekben az esetekben a hangsúly a kvantitatív elemeken van. Természetesen meg lehetne bontani az egyes eszközöket kvantitatív és kvalitatív részekre (pl. a tervezés során a tevékenységek azonosítása kvalitatív, míg az időtartam, kritikus út, erőforrás-szükséglet meghatározása kvantitatív), azonban a kvantitatív eszközök egyértelmüen dominánsak a tervezés során (vö. Görög, 2013a). Egyetlen kivételt a tartalmi-terjedelmi behatárolás jelenti, amelyen belül a kvalitatív eszközök komoly szerepet kapnak, ezért ez a következő kategóriába került. Olyan tevékenység, amelyen belül a kvantitatív és kvalitatív eszközök egyaránt fontos szerepet kapnak, az a behatárolás, az optimalizálás, a termékbeli kiválóság és a elvárt

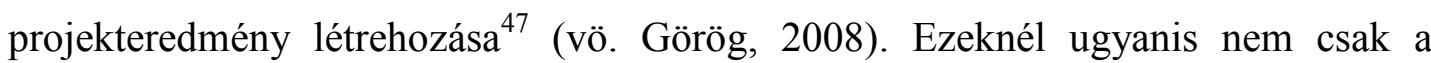
számításokra, hanem a következmények végiggondolására, az érdekek megfelelő leképeződésére legalább akkora hangsúly helyeződik, mint a számolásokra. Kivételes eszköznek tekinthető az elvárt projekteredmény létrehozása, amely alatt a

\footnotetext{
${ }^{47}$ Az optimalizálás esetén elfogadásra került a change management is. Ez a tevékenység továbbá jellegénél fogva összetett, több tényezö tartozik bele, ilyen a projektháromszög változtatása (illetve a scope változtatása) vagy plusz erőforrások bevonása. Ennek részletes taglalása azonban nem képezi a dolgozat tartalmát. Amennyiben már legalább egy eszközt említ, az elégséges volt ahhoz, hogy ez a kategória kerüljön említésre.
} 
projektvezetők azt értették, hogy azt a terméket kapja meg, amit a projekttulajdonos (vevő) szeretne. Természetesen ez összefügg a tartalmi-terjedelmi behatárolással, de annál eggyel bővebb, hiszen ez már nem a tervezés fázisában fejti ki hatását, hanem a teljesítés során. Kontrollnak sem tekinthető, hiszen a kontroll „csupán” ellenőrzi, hogy a megfelelő mederben történik-e a teljesítés. A termékbeli kiválóság a projekteredmény biztosításához hasonló eszköz, hiszen ez alatt a projektvezetők azt értették, hogy a minőség kerül a teljesítés középpontjába, és ezt próbálják biztosítani. Kvalitatív eszközöket tartalmazó tevékenységek közé pedig a kommunikáció és az érintettek kezelése került besorolásra. Elöbbi természetesen igen tág tevékenység, hiszen beletartozik a tervezés, optimalizálás stb. során alkalmazott kommunikáció a többi érintettel, a projektcsapattal történő rendszeres kapcsolattartás, a projekttulajdonosi szervezettel való rendszeres egyeztetés, az eszkaláció stb. Tehát minden olyan iteráció ide értendő, amihez kommunikációt kell használni. Utóbbi alatt pedig minden olyat értünk, amely az érintettekhez kapcsolódó eszköz (vö. Görög, 2003), kivéve a kommunikációt. Ilyenre példa a bevonás, a megfelelő munkakörnyezet megteremtése vagy oktatás tartása.

A projektvezetők a 11., 12., 13. táblázat szerinti válaszokat adták arra, hogy milyen módon sikerült elősegíteni az adott sikerszintet (zárójelben az látható, hogy hány projektvezető adta az adott választ):

11. táblázat: A projektvezetési eszközök hatása a projektháromszög szerinti sikerességre

\begin{tabular}{|l|l|l|l|}
\hline $\begin{array}{l}\text { Projektháromszög } \\
\text { szerinti sikeresség }\end{array}$ & $\begin{array}{l}\text { Kvantitatív } \\
\text { eszközök }\end{array}$ & $\begin{array}{l}\text { Kvalitatív és } \\
\text { kvantitatív } \\
\text { eszközök }\end{array}$ & $\begin{array}{l}\text { Kvalitatív } \\
\text { eszközök }\end{array}$ \\
\hline 1. vállalat & $\begin{array}{l}\text { tervezés (10), } \\
\text { kontroll (7) }\end{array}$ & $\begin{array}{l}\text { tartalmi- } \\
\text { terjedelmi } \\
\text { behatárolás (2), } \\
\text { optimalizálás (7) }\end{array}$ & $\begin{array}{l}\text { érintettek } \\
\text { kezelése (8), } \\
\text { kommunikáció (3) }\end{array}$ \\
\hline 2. vállalat & $\begin{array}{l}\text { tervezés (4), } \\
\text { tartalmi- } \\
\text { terjedelmi } \\
\text { behatárolás (1), } \\
\text { optimalizálás (3) }\end{array}$ & $\begin{array}{l}\text { érintettek } \\
\text { kezelése (0), }\end{array}$ \\
\hline 3. vállalat & $\begin{array}{l}\text { tartalmi- } \\
\text { terjedelmi } \\
\text { behatárolás (3), } \\
\text { optimalizálás (6) }\end{array}$ & $\begin{array}{l}\text { érintettek } \\
\text { kezelése (4), } \\
\text { kommunikáció (4) }\end{array}$ \\
\hline
\end{tabular}




\begin{tabular}{|l|l|l|l|} 
4. vállalat & $\begin{array}{l}\text { tervezés (2), } \\
\text { kontroll (2) }\end{array}$ & $\begin{array}{l}\text { tartalmi- } \\
\text { terjedelmi } \\
\text { behatárolás (0), } \\
\text { optimalizálás (2) }\end{array}$ & $\begin{array}{l}\text { érintettek } \\
\text { kezelése (0), } \\
\text { kommunikáció (1) }\end{array}$ \\
\hline 5. vállalat & $\begin{array}{l}\text { tervezés (6), } \\
\text { kontroll (4) }\end{array}$ & $\begin{array}{l}\text { tartalmi- } \\
\text { terjedelmi } \\
\text { behatárolás (3), } \\
\text { optimalizálás (3) }\end{array}$ & $\begin{array}{l}\text { érintettek } \\
\text { kezelése (0), } \\
\text { kommunikáció (4) }\end{array}$ \\
\hline Összesen & $\begin{array}{l}\text { tervezés (28), } \\
\text { kontroll (23) } \\
\text { terjedelmi- } \\
\text { behatárolás (9), } \\
\text { optimalizálás (21) }\end{array}$ & $\begin{array}{l}\text { érintettek } \\
\text { kezelése (7), } \\
\text { kommunikáció }\end{array}$ \\
\hline
\end{tabular}

Forrás: saját szerkesztés

12. táblázat: A projektvezetési eszközök hatása a projekttulajdonosi

\section{elégedettség szerinti sikerességre}

\begin{tabular}{|c|c|c|c|}
\hline $\begin{array}{l}\text { Projekttulajdonosi } \\
\text { elégedettség szerinti } \\
\text { sikeresség }\end{array}$ & $\begin{array}{l}\text { Kvantitatív } \\
\text { eszközök }\end{array}$ & $\begin{array}{l}\text { Kvalitatív és } \\
\text { kvantitatív } \\
\text { eszközök }\end{array}$ & $\begin{array}{l}\text { Kvalitatív } \\
\text { eszközök }\end{array}$ \\
\hline 1. vállalat & & $\begin{array}{l}\text { elvárt } \\
\text { projekteredmény } \\
\text { létrehozása (1), } \\
\text { tartalmi- } \\
\text { terjedelmi } \\
\text { behatárolás (6) }\end{array}$ & $\begin{array}{l}\text { kommunikáció (9), } \\
\text { érintettek } \\
\text { kezelése (4) }\end{array}$ \\
\hline 2. vállalat & & $\begin{array}{l}\text { elvárt } \\
\text { projekteredmény } \\
\text { létrehozása (4), } \\
\text { tartalmi- } \\
\text { terjedelmi } \\
\text { behatárolás (2) } \\
\end{array}$ & $\begin{array}{l}\text { kommunikáció (4), } \\
\text { érintettek } \\
\text { kezelése (4) }\end{array}$ \\
\hline 3. vállalat & & $\begin{array}{l}\text { elvárt } \\
\text { projekteredmény } \\
\text { létrehozása (3), } \\
\text { tartalmi- } \\
\text { terjedelmi } \\
\text { behatárolás (2) }\end{array}$ & $\begin{array}{l}\text { kommunikáció (5), } \\
\text { érintettek } \\
\text { kezelése (1) } \\
\end{array}$ \\
\hline 4. vállalat & & $\begin{array}{l}\text { elvárt } \\
\text { projekteredmény } \\
\text { létrehozása (1), } \\
\text { tartalmi- } \\
\text { terjedelmi } \\
\text { behatárolás (2) }\end{array}$ & $\begin{array}{l}\text { kommunikáció (2), } \\
\text { érintettek } \\
\text { kezelése (0) }\end{array}$ \\
\hline
\end{tabular}




\begin{tabular}{|l|l|l|} 
5. vállalat & $\begin{array}{l}\text { elvárt } \\
\text { projekteredmény } \\
\text { létrehozása (4), } \\
\text { tartalmi- } \\
\text { terjedelmi } \\
\text { behatárolás (0) }\end{array}$ & $\begin{array}{l}\text { kommunikáció (5), } \\
\text { érintettek } \\
\text { kezelése (1) }\end{array}$ \\
\hline Összesen & $\begin{array}{l}\text { elvárt } \\
\text { projekteredmény } \\
\text { létrehozása (14), } \\
\text { tartalmi- } \\
\text { terjedelmi } \\
\text { behatárolás (11) }\end{array}$ & $\begin{array}{l}\text { kommunikáció } \\
(24), \\
\text { érintettek } \\
\text { kezelése (10) }\end{array}$ \\
\hline
\end{tabular}

Forrás: saját szerkesztés

13. táblázat: A projektvezetési eszközök hatása az egyéb érintettek szerinti sikerességre

\begin{tabular}{|c|c|c|c|}
\hline $\begin{array}{l}\text { Érintettek } \\
\text { elégedettsége } \\
\text { szerinti sikeresség }\end{array}$ & \begin{tabular}{|l}
$\begin{array}{l}\text { Kvantitatív } \\
\text { eszközök }\end{array}$ \\
\end{tabular} & $\begin{array}{l}\text { Kvalitatív és } \\
\text { kvantitatív } \\
\text { eszközök }\end{array}$ & $\begin{array}{l}\text { Kvalitatív } \\
\text { eszközök }\end{array}$ \\
\hline 1. vállalat & kontroll (2) & $\begin{array}{l}\text { tartalmi- } \\
\text { terjedelmi } \\
\text { behatárolás (2), } \\
\text { optimalizálás (2), } \\
\text { termékbeli } \\
\text { kiválóság (2) } \\
\end{array}$ & \begin{tabular}{|l} 
\\
érintettek \\
kezelése (7), \\
kommunikáció (7)
\end{tabular} \\
\hline 2. vállalat & kontroll (0) & $\begin{array}{l}\text { tartalmi- } \\
\text { terjedelmi } \\
\text { behatárolás (0), } \\
\text { optimalizálás (1), } \\
\text { termékbeli } \\
\text { kiválóság (0) } \\
\end{array}$ & $\begin{array}{l}\text { érintettek } \\
\text { kezelése (5), } \\
\text { kommunikáció (4) }\end{array}$ \\
\hline 3. vállalat & kontroll (0) & $\begin{array}{l}\text { tartalmi- } \\
\text { terjedelmi } \\
\text { behatárolás (4), } \\
\text { optimalizálás (0), } \\
\text { termékbeli } \\
\text { kiválóság (1) } \\
\end{array}$ & $\begin{array}{l}\text { érintettek } \\
\text { kezelése (4), } \\
\text { kommunikáció (4) }\end{array}$ \\
\hline 4. vállalat & kontroll (0) & $\begin{array}{l}\text { tartalmi- } \\
\text { terjedelmi } \\
\text { behatárolás (0), } \\
\text { optimalizálás (1), } \\
\text { termékbeli } \\
\text { kiválóság (1) }\end{array}$ & $\begin{array}{l}\text { érintettek } \\
\text { kezelése (1), } \\
\text { kommunikáció (2) }\end{array}$ \\
\hline
\end{tabular}




\begin{tabular}{|l|l|l|l|} 
5. vállalat & & $\begin{array}{l}\text { tartalmi- } \\
\text { terjedelmi } \\
\text { behatárolás (0), } \\
\text { optimalizálás (0), } \\
\text { termékbeli } \\
\text { kiválóság (0) }\end{array}$ & $\begin{array}{l}\text { érintettek } \\
\text { kezelése (3), } \\
\text { kommunikáció (4) }\end{array}$ \\
\hline Összesen & kontroll (0) & $\begin{array}{l}\text { tartalmi- } \\
\text { terjedelmi } \\
\text { behatárolás (7), } \\
\text { optimalizálás (2), } \\
\text { termékbeli } \\
\text { kiválóság (3) }\end{array}$ & $\begin{array}{l}\text { érintettek } \\
\text { kezelése (20), } \\
\text { kommunikáció } \\
\text { (21) }\end{array}$ \\
\hline
\end{tabular}

Forrás: saját szerkesztés

A kutatás eredményét három részre lehet bontani, csakúgy, mint a kutatási kérdést és a hipotézist.

A projektháromszög szerinti sikeresség biztosítása során megállapítható, hogy a kvantitatív eszközöket tartalmazó tevékenységek számosságukban mindenképp dominálják a kvalitatív eszközöket tartalmazó tevékenységeket. Különösen a tervezés rendkívül jelentős, amelyet egyetlen projektvezető kivételével mindenki említett. De hasonló fontossággal bír a kontroll is, amelyet hat projektvezető kivételével mindenki említett. Gyakran említett továbbá az optimalizálás (21) és a kommunikáció (20) is. A megfelelő tartalmi-terjedelmi behatárolás (9) és érintettek kezelése (7) kevésbé bír fontossággal a projektvezetők szerint. A tartalmi-terjedelmi behatárolás alacsony számára magyarázata sok esetben az, hogy magára a projekteredményre kevés ráhatása van egy multinacionális vállalatnál dolgozó projektvezetőnek, hiszen az üzleti igényeket már készen kapja. Természetesen ezt némiképp tudja kompenzálni, ha pl. tekintélye révén befolyásra tesz szert a szervezeten belül vagy amikor úgynevezett belső projektről van szó. Az érintettek kezelésére pedig az lehet a magyarázat, hogy hierarchikus eszközök (pl. főnökibeosztotti viszony) vagy kommunikáció révén igyekszik megvalósítani azt, hogy a projektcsapat megfelelő módon elvégezze a feladatokat.

Összességében megállapíthat, hogy a kvantitatív eszközöket tartalmazó tevékenységeket több projektvezető alkalmazza (vagy többször), azonban egyértelmüen nem jelenthető ki, hogy nagyobb mértékben járulnak hozzá a sikeresség ezen aspektusához, még annak ellenére sem, hogy 51 ilyet említettek. Ez pedig egy ténynek köszönhető. Azon projektvezetők többsége, akik említették a 
kommunikációt, kijelentették, hogy kommunikáció nélkül nem müködik semmilyen terv. Így a kvalitatív eszközökre nem hagyatkozó projektvezető igen kevés (csupán 8). 20 olyan projektvezető van, aki említette a kommunikáció szükségességét a tervezés mellett, míg egy olyan, aki a érintettek kezeléseettel tette mindezt (úgy, hogy a kommunikációt nem említette). Ezek alapján - bár látszólag úgy tűnhet, hogy a kvantitatív eszközök nagyobb mértékben járulnak hozzá a projektháromszög szerinti sikerességhez, mint a kvalitatívak - kijelenthetö, hogy a kvalitatív eszközök nem bírnak kisebb fontossággal a projektháromszög szerinti sikeresség elérésében, mint a kvantitatívak. Természetesen ez nem azt jelenti (ahogy korábban megállapításra került), hogy a kvantitatív eszközök számosságukat tekintve ne dominálnának a projektsiker ezen aspektusában, csupán azt, hogy a kettő együttes alkalmazására van szükség.

Mindezek alapján az első hipotézis első eleme elvethető.

A projekttulajdonosi elégedettség eléréséhez szükséges projektvezetési eszközök vizsgálata során megállapítható, hogy tisztán kvantitatív eszközöket tartalmazó tevékenységeket a projektvezetők nem említettek, legfeljebb olyanokat, ahol a kvantitatív és a kvalitatív jegyek egyaránt megjelennek, azaz a tartalmiterjedelmi behatárolást és azt, hogy azt a projekteredményt szállítsák le, amit a projekttulajdonos (vevő) szeretne. A legfontosabbnak a projektvezetők a kommunikációt tekintették, a 29-ból 24 projektvezető érezte kiemelten fontosnak ennek a használatát. Ezen belül 10 projektvezető fontosnak tartotta, hogy kommunikációs eszközként megjelenjen a folyamatos beszámolás a termékről, azaz egyfajta jelentés a projektteljesítés állapotáról. Második legfontosabbnak az elvárt projekteredmény létrehozását tekintették (közel a projektvezetők fele érezte fontosnak ezt a projektsiker ezen aspektusának biztosítása esetén), míg harmadik helyre a behatárolás került (11 projektvezető által). Ez természetesen szoros összefüggésben áll az elvárt projekteredmény létrehozásval, bár 6 olyan projektvezető volt, akik nem tartották egyidejűleg fontosnak ezt a kettőt. Legvégső helyre az érintettek kezelése került az említettek közül, ami annak köszönhetö, hogy a projekttulajdonos (vevő) kiemelt érintett, ezért külön említették eszközként a vele való kommunikációt, az egyéb módszereket körülbelül a projektvezetők mintegy harmada tartotta csupán fontosnak (pl. hogy a projekttulajdonosi szervezetnek ne csak a döntéshozói legyenek elégedettek, hanem minden olyan személy, aki 
kapcsolatba kerül a projekttel, ami eredményezheti a projekttulajdonosi szervezet vezetőinek elégedettségét).

Figyelembe véve ezeket a tényeket, kijelenthető, hogy a kvantitatív elemek nem fontosabbak a projektsiker projekttulajdonosi elégedettség aspektusának elérése szempontjából. Fordítva, azaz, hogy a kvalitatív projektvezetési eszközök nagyobb mértékben hozzájárulnak a projekttulajdonosi szervezet elégedettségéhez, mint a kvantitatívak, már nagyobb eséllyel jelenthető ki, azonban a minta alapján ez sem állítható egyértelmüen (bár jelentős esély mutatkozik erre).

Mindezek alapján az első hipotézis második eleme elvethető.

A harmadik lépést az érintettek elégedettségére hatást gyakorló eszközök vizsgálata jelentette. A projektvezetők válaszai alapján a leggyakoribb és legfontosabb a kommunikáció és az érintettek kezelése volt. Csupán 9 olyan projektvezető volt, aki nem említette a kommunikációt fontosnak. A válaszadók közül az egyik projektvezető kijelentette, hogy a projektsiker ezen aspektusa nem releváns számára, hiszen Ő az érintettekkel nem foglalkozik. Így a minta ebben az esetben nem 29, hanem csupán 28. Másik érdekesség, hogy a 4. vállalat esetén mindkét projektvezető fontosnak tartotta a kommunikációt, holott ők még indirekten sem állnak kapcsolatban a végfelhasználókkal. További kiemelendő pont, hogy a tisztán kvalitatív eszközöket tartalmazó tevékenységek (érintettek kezelését és kommunikációt) csupán két projektvezető nem említette. Míg 16 olyan projektvezető volt, aki csak kvalitatív eszközöket tartalmazó tevékenységeket alkalmaz ennek a sikerszintnek a biztosítása érdekében. Szintén érdekes, hogy a projektsiker egyik leginkább kvalitatívnak tartott kritériumát, az érintettek elégedettségét (vö. Görög, 2003) két projektvezető is elösegíti kvantitatív eszközöket tartalmazó tevékenységgel. Meg kell említeni továbbá azt is, hogy csupán egy olyan projektvezető volt, aki egynél több kvantitatív vagy kvantitatív és kvalitatív eszközt tartalmazó tevékenységet (termékbeli kiválóság, tartalmi-terjedelmi behatárolás, optimalizálás, kontroll) alkalmazott. Ö is a tartalmi-terjedelmi behatárolás és a termékbeli kiválóság együttes elérését tartotta fontosnak.

Összességében megállapítható tehát, hogy az érintettek elégedettsége szerinti projektsiker aspektus esetében a kvalitatív eszközök számosságukban dominálnak. Nem volt olyan projektvezető, aki szerint a kvantitatív projektvezetési eszközök 
alkalmazása nagyobb mértékben elősegítené ennek a projektsiker aspektusnak a teljesülését. Ellenben 16 olyan projektvezető volt, aki csak kvalitatív eszközöket tartalmazó tevékenységet alkalmaz ahhoz, hogy elősegítse az érintettek elégedettsége sikerkritérium teljesülését.

Mindezek fényében kijelenthető, hogy az első hipotézis harmadik eleme elvethető, és így az első hipotézis elvethető.

\subsubsection{A projektvezető által alkalmazott projektvezetési szemlélet azonosítása}

A kutatás második része során a fókuszt a projektvezető végzettsége, az alkalmazott projektvezetési szemléletmódja jelentette, és az, hogy ennek a szemléletmódnak a keretében alkalmazott eszközök során a tacit vagy explicit tudás dominál-e. Utóbbihoz meg kellett kérdezni, hogy az eszközöket a projektvezetési szemléletmódjuknak a keretében alkalmazza-e, valamint azt, hogy ezeknek az eszközök tartalma a használatuk során fejlődtek-e, illetve azt, hogy ezek az eszközök inkább elsajátíthatóak vagy megtanulhatóak. Azaz szakkönyvekből, hagyományos ismeretátadásra koncentráló kurzusból megtanulható, vagy olyan módon kell a tudást átadni, hogy a tacit elemek is elsajátíthatóak legyenek (vö. Horváth, 2013).

A projektvezető végzettsége két tényező miatt lehet fontos. Egyrészt a végzettség mintegy utólag validálhatja az első két kérdésre (az ismert és alkalmazott projektvezetési eszközökre) adott választ. Másrészt az interjú negyed részének első két kérdése során is támpontot nyújthat, azaz akkor, amikor megkérdezésre kerül, hogy milyen tényezők gyakoroltak hatást a projektvezető vezetési stílusára és szemléletmódjára.

A projektvezetők végzettsége a 14. táblázat szerint alakult ${ }^{48}$ :

14. táblázat: A projektvezetők végzettsége

\begin{tabular}{|l|l|l|l|}
\hline & Egyetemi végzettség & $\begin{array}{l}\text { Projektvezetői } \\
\text { végzettség }\end{array}$ \\
\hline \multirow{4}{*}{ 1. vállalat } & 1. interjúalany & rendszervező, közgazdász & PMP \\
\cline { 2 - 4 } & \begin{tabular}{l} 
2. interjúalany \\
\cline { 2 - 4 }
\end{tabular} & orvos & - \\
\hline 4. interjúalany & $\begin{array}{l}\text { villamosmérnök, tanár, } \\
\text { MBA }\end{array}$ & - \\
\hline
\end{tabular}

${ }^{48}$ A 3. és 17. interjúalany korábban kivételre került a mintából. 


\begin{tabular}{|c|c|c|c|}
\hline & 5. interjúalany & $\begin{array}{l}\text { müszaki (2 db), közgazdász } \\
(2 \mathrm{db})\end{array}$ & IPMA minősítés \\
\hline & 6. interjúalany & programozó matematikus & SSADM, PMP \\
\hline & 7. interjúalany & közlekedésmérnök & - \\
\hline & 8. interjúalany & mérnök & PMP \\
\hline & 9. interjúalany & $\begin{array}{l}\text { informatikus, mérnök, } \\
\text { pedagógus }\end{array}$ & - \\
\hline & $\begin{array}{l}10 . \\
\text { interjúalany }\end{array}$ & müszaki, MBA & - \\
\hline & $\begin{array}{l}11 . \\
\text { interjúalany }\end{array}$ & $\begin{array}{l}\text { müszaki-informatikus, } \\
\text { közgazdász }\end{array}$ & - \\
\hline \multirow{5}{*}{ 2. vállalat } & $\begin{array}{l}12 . \\
\text { interjúalany }\end{array}$ & közgazdász, újságíró & PMP, Six Sigma Black Belt \\
\hline & $\begin{array}{l}13 . \\
\text { interjúalany }\end{array}$ & informatikus, PSZF & PMP \\
\hline & $\begin{array}{l}14 . \\
\text { interjúalany }\end{array}$ & közgazdász, MBA & - \\
\hline & $\begin{array}{l}15 . \\
\text { interjúalany }\end{array}$ & mérnök, közgazdász & PMP \\
\hline & $\begin{array}{l}16 . \\
\text { interjúalany }\end{array}$ & mérnök & PMP \\
\hline \multirow{6}{*}{$\begin{array}{c}3 . \\
\text { vállalat }\end{array}$} & $\begin{array}{l}18 . \\
\text { interjúalany }\end{array}$ & mérnök & PMP \\
\hline & $\begin{array}{l}19 . \\
\text { interjúalany }\end{array}$ & $\begin{array}{l}\text { gazd. mérnök, mérlegképes } \\
\text { könyvelö }\end{array}$ & PMP \\
\hline & $\begin{array}{l}20 . \\
\text { interjúalany }\end{array}$ & $\begin{array}{l}\text { mérnök-informatikus, } \\
\text { mérnök-közgazdász }\end{array}$ & PMP \\
\hline & $\begin{array}{l}21 . \\
\text { interjúalany }\end{array}$ & mérnök & Six Sigma Black Belt \\
\hline & $\begin{array}{l}22 . \\
\text { interjúalany }\end{array}$ & $\begin{array}{l}\text { szervezői-informatikai, } \\
\text { gazdasági, MBA }\end{array}$ & - \\
\hline & $\begin{array}{l}23 . \\
\text { interjúalany }\end{array}$ & mérnök & PMP \\
\hline \multirow{2}{*}{ 4. vállalat } & $\begin{array}{l}24 . \\
\text { interjúalany }\end{array}$ & informatikus & - \\
\hline & $\begin{array}{l}25 . \\
\text { interjúalany }\end{array}$ & müszaki informatikus & - \\
\hline \multirow[t]{2}{*}{ 5. vállalat } & $\begin{array}{l}26 . \\
\text { interjúalany } \\
\end{array}$ & $\begin{array}{l}\text { villamosmérnök, } \\
\text { közgazdász } \\
\end{array}$ & PMP \\
\hline & 27. & mérnök & - \\
\hline
\end{tabular}




\begin{tabular}{|l|l|l|l|} 
interjúalany & & \\
$\begin{array}{l}\mathbf{2 8 .} \\
\text { interjúalany }\end{array}$ & matematikus, közgazdász & PMP \\
\hline $\begin{array}{l}\text { 29. } \\
\text { interjúalany }\end{array}$ & $\begin{array}{l}\text { villamosmérnök, } \\
\text { informatikus }\end{array}$ & PMP \\
\hline $\begin{array}{l}\text { 30. } \\
\text { interjúalany }\end{array}$ & villamosmérnök & PMP \\
\hline $\begin{array}{l}\text { 31. } \\
\text { interjúalany }\end{array}$ & mérnök-informatikus & - \\
\hline
\end{tabular}

Forrás: saját szerkesztés

A 14. táblázat alapján megállapítható, hogy mindenki rendelkezik informatikus vagy mérnöki végzettséggel (kivéve a 14. interjúalanyt). Valamint az, hogy 17 interjúalany rendelkezik valamilyen projektvezetői képesítéssel, további kettőnek pedig folyamatban van egy ilyen képesítés megszerzése. Ezek alapján leszögezhető, hogy a korábban említett eszközöknek valószínüsíthetőleg tényleg a birtokában vannak, így utólag a minta ilyen irányú validálása megtörtént. Továbbá az is az egyetemi és projektvezetői végzettség alapján kijelenthető, hogy megfelelő és releváns szemléletmód birtokában lehetnek a projektvezetők (vö. Cleland, 1994).

A következő lépés ezen a részen belül a projektvezetők projektvezetési szemléletmódjának feltérképezése volt. Három markáns projektvezetési szemléletmód lehetséges. Az első szerint a projektvezető a projektre mind egyedi feladat tekint, így a projektvezetési tevékenység fókuszában a projektfolyamat vezetése áll, így a projektvezetési szemléletmódja projektfolyamat-centrikus. A második szerint a projektre mint ideiglenes szervezetre tekint, így a projektevezetési tevékenység fókuszában az ideiglenes szervezet vezetése áll, így a projektvezetési szemléletmódja érintett-centrikus. A harmadik szerint a projektre mint stratégiai építőelemre tekint, így a projektvezetési tevékenység fókuszában a projekt által elérendő kedvezető változás biztosítása áll, így szemléletmódja stratégia-orientált. Ennél a kérdésnél az került megkérdezésre, hogy mi az a vezérfonal, ami alapján vezeti a projektjeit, azaz milyen projektvezetési szemléletmódot követ. Az értékelés során ez képezte az alapot. Amennyiben a projektvezető a tervek teljesülését tartotta fontosnak, akkor projektfolyamat-centrikus projektvezetési szemléletmódot követ. Amennyiben a projektvezető az érintettek vezetését (különösen a projektcsapatét) 
helyezte a középpontba, akkor érintett-centrikus projektvezetési szemléletmódot követ. Amennyiben a projektvezető a vállalat érdekét vagy stratégiáját tartotta elsődlegesen fontosnak, akkor a projektvezető stratégia-orientált megközelítést követ.

A projektvezetők projektvezetési szemléletmódját 15. táblázat foglalja össze. A második oszlopban a projektvezetők által adott részletesebb leírás található.

15. táblázat: A projektvezetők projektvezetési szemléletmódja

\begin{tabular}{|c|c|c|c|}
\hline & & $\begin{array}{l}\text { Projektvezetők } \\
\text { válaszai a } \\
\text { szemléletmódra }\end{array}$ & $\begin{array}{l}\text { Projektvezetési } \\
\text { szemléletmód }\end{array}$ \\
\hline \multirow{10}{*}{$\begin{array}{c}1 . \\
\text { vállalat }\end{array}$} & $\begin{array}{c}1 . \\
\text { interjúalany }\end{array}$ & $\begin{array}{l}\text { emberközpontúság, } \\
\text { érintettek kezelése }\end{array}$ & érintett-centrikus \\
\hline & $\begin{array}{c}2 . \\
\text { interjúalany }\end{array}$ & $\begin{array}{l}\quad \text { érintettekkel történő } \\
\text { kapcsolat fontossága, } \\
\text { leszállít, amit a vevő } \\
\text { szeretne }\end{array}$ & érintett-centrikus \\
\hline & $\begin{array}{c}4 . \\
\text { interjúalany }\end{array}$ & kollégák fontossága & érintett-centrikus \\
\hline & $\begin{array}{c}5 . \\
\text { interjúalany }\end{array}$ & \begin{tabular}{l}
\multicolumn{1}{c}{ konfliktusok } \\
megfelelő kezelése, \\
megfelelő projektkezelés \\
("projektek eladása")
\end{tabular} & érintett-centrikus \\
\hline & $\begin{array}{c}6 . \\
\text { interjúalany }\end{array}$ & $\begin{array}{l}\text { módszeresség, } \\
\text { tervezettség }\end{array}$ & $\begin{array}{l}\text { projektfolyamat- } \\
\text { centrikus }\end{array}$ \\
\hline & $\begin{array}{c}7 . \\
\text { interjúalany }\end{array}$ & $\begin{array}{l}\text { alapos tervezettség, } \\
\text { folyamat-centrikusság }\end{array}$ & $\begin{array}{l}\text { projektfolyamat- } \\
\text { centrikus }\end{array}$ \\
\hline & $\stackrel{8 .}{\text { interjúalany }}$ & $\begin{array}{l}\quad \text { teljesíti a vevői } \\
\text { igényeket, de segít a } \\
\text { vevőnek kialakítani a } \\
\text { legjobb megoldást }\end{array}$ & stratégia-orientáltság \\
\hline & $\begin{array}{c}9 . \\
\text { interjúalany }\end{array}$ & $\begin{array}{l}\text { tiszta, világos célok, } \\
\text { és ezek elérése }\end{array}$ & $\begin{array}{l}\text { projektfolyamat- } \\
\text { centrikus }\end{array}$ \\
\hline & $\begin{array}{c}10 . \\
\text { interjúalany }\end{array}$ & $\begin{array}{l}\text { határidő tartása, } \\
\text { magas morállal rendelkező } \\
\text { projektcsapat, csapatjáték }\end{array}$ & $\begin{array}{l}\quad \text { projektfolyamat- } \\
\text { centrikus, } \\
\text { érintett-centrikus }\end{array}$ \\
\hline & $\begin{array}{c}11 . \\
\text { interjúalany }\end{array}$ & érintett-centrikusság & érintett-centrikus \\
\hline 2. & $\begin{array}{c}12 . \\
\text { interjúalany }\end{array}$ & $\begin{array}{l}\text { szolgálat, környezet } \\
\text { figyelembevétele }\end{array}$ & érintett-centrikus \\
\hline
\end{tabular}




\begin{tabular}{|c|c|c|c|}
\hline \multirow[t]{4}{*}{ vállalat } & $\begin{array}{c}13 . \\
\text { interjúalany }\end{array}$ & érintett-centrikusság & érintett-centrikus \\
\hline & $\begin{array}{c}14 . \\
\text { interjúalany }\end{array}$ & $\begin{array}{l}\text { ügyfél érdekének } \\
\text { figyelembevétele }\end{array}$ & stratégia-orientált \\
\hline & $\begin{array}{c}15 . \\
\text { interjúalany }\end{array}$ & $\begin{array}{l}\quad \text { projektcsapat- } \\
\text { központú vezetés, projekt } \\
\text { céljainak megértése a } \\
\text { projektcsapat által, } \\
\text { megfelelő stílust és irányt } \\
\text { szabjon a projektnek }\end{array}$ & érintett-centrikus \\
\hline & $\begin{array}{c}16 . \\
\text { interjúalany }\end{array}$ & $\begin{array}{l}\text { feladat, amit meg } \\
\text { kell csinálni }\end{array}$ & $\begin{array}{l}\text { projektfolyamat- } \\
\text { centrikus }\end{array}$ \\
\hline \multirow{6}{*}{$\begin{array}{r}3 . \\
\text { vállalat }\end{array}$} & $\begin{array}{c}18 . \\
\text { interjúalany }\end{array}$ & $\begin{array}{l}\quad \text { mindenki találja meg } \\
\text { a célját a projektben, } \\
\text { csapat-centrikusság }\end{array}$ & érintett-centrikus \\
\hline & $\begin{array}{c}19 . \\
\text { interjúalany }\end{array}$ & $\begin{array}{l}\text { motiváló atmoszféra, } \\
\text { dicséret, végső esetben a } \\
\text { projekttagok büntetése }\end{array}$ & érintett-centrikus \\
\hline & $\begin{array}{c}20 . \\
\text { interjúalany }\end{array}$ & megoldandó feladat & $\begin{array}{l}\text { projektfolyamat- } \\
\text { centrikus }\end{array}$ \\
\hline & $\begin{array}{c}21 . \\
\text { interjúalany }\end{array}$ & $\begin{array}{l}\quad \text { üzleti haszon van a } \\
\text { középpontban, illetve } \\
\text { érezzék az emberek, hogy } \\
\text { van értelme }\end{array}$ & stratégia-orientált \\
\hline & $\begin{array}{c}22 . \\
\text { interjúalany }\end{array}$ & $\begin{array}{l}\text { stratégiával } \\
\text { összhangban }\end{array}$ & stratégia-orientált \\
\hline & $\begin{array}{c}23 . \\
\text { interjúalany }\end{array}$ & $\begin{array}{l}\text { tervezés alapú, } \\
\text { strukturált feladat }\end{array}$ & $\begin{array}{l}\text { projektfolyamat- } \\
\text { centrikus }\end{array}$ \\
\hline \multirow[t]{2}{*}{$\begin{array}{r}4 . \\
\text { vállalat }\end{array}$} & $\begin{array}{c}24 . \\
\text { interjúalany }\end{array}$ & $\begin{array}{l}\quad \text { bár az interjúalany a } \\
\text { stratégia-centrikusságot } \\
\text { említette, azonban a többi } \\
\text { válasz alapján inkább } \\
\text { folyamat-centrikus, hiszen } \\
\text { a korábbi válaszaiban a } \\
\text { tervezésre és a tervek } \\
\text { realizálására helyezte a } \\
\text { hangsúlyt }\end{array}$ & $\begin{array}{l}\text { projektfolyamat- } \\
\text { centrikus }\end{array}$ \\
\hline & $\begin{array}{c}25 . \\
\text { interjúalany }\end{array}$ & $\begin{array}{l}\quad \text { minőség-centrikus } \\
\text { (és ebből fakadóan } \\
\text { folyamat-centrikusság) }\end{array}$ & $\begin{array}{l}\text { projektfolyamat- } \\
\text { centrikus }\end{array}$ \\
\hline $\begin{array}{c}5 . \\
\text { vállalat }\end{array}$ & $\begin{array}{l}26 . \\
\text { interjúalany }\end{array}$ & $\begin{array}{l}\text { projekt elején a szabályok } \\
\text { lefektetése, pozitív attitüd } \\
\text { megteremtése a } \\
\text { projektcsapaton belül }\end{array}$ & érintett-centrikus \\
\hline
\end{tabular}




\begin{tabular}{|l|l|l|l|}
$\begin{array}{l}\mathbf{2 7 .} \\
\text { interjúalany }\end{array}$ & $\begin{array}{l}\text { a vállalat (vevő) érdeke } \\
\text { van a középpontban }\end{array}$ & stratégia-orientált \\
\hline $\begin{array}{l}\mathbf{2 8 .} \\
\text { interjúalany }\end{array}$ & $\begin{array}{l}\text { vállalat (vevö) van a } \\
\text { középpontban }\end{array}$ & stratégia-orientált \\
\hline $\begin{array}{l}\mathbf{2 9 .} \\
\text { interjúalany }\end{array}$ & $\begin{array}{l}\text { technika megértése } \\
\text { (folyamatok) és a } \\
\text { csapatjáték fontossága }\end{array}$ & $\begin{array}{l}\text { projektfolyamat-centrikus, } \\
\text { érintett-centrikus }\end{array}$ \\
\hline $\begin{array}{l}\mathbf{3 0 .} \\
\text { interjúalany }\end{array}$ & $\begin{array}{l}\text { szervezett, rendben folyó } \\
\text { munka és motivált, } \\
\text { jókedvű projektcsapat }\end{array}$ & érintett-centrikus \\
\hline $\begin{array}{l}\text { 31. } \\
\text { interjúalany }\end{array}$ & $\begin{array}{l}\text { emberközpontúság, } \\
\text { megfelelö atmoszféra } \\
\text { megteremtése }\end{array}$ & érintett-centrikus \\
\hline
\end{tabular}

Forrás: saját szerkesztés

Az alkalmazott projektvezetési szemléletmód megfelelő kategorizálása mintegy utólagos ellenőrzésként összevetésre került az alkalmazott projektvezetési eszközökkel. Ez támpontot jelenthet, hogy helyesen kategorizálta-e magát a projektvezető. Például az a projektvezető, aki érintett-centrikusnak vallja magát, de nem használja az érintett-elemzést sem a projektsiker adott szintjeinek elérése során, sem pedig általánosan, akkor nem lehet érintett-centrikus. Ez alapján került megváltoztatásra a 24. interjúalany szemléletmódja.

Az alkalmazott projektvezetési szemléletmódok a 16. táblázat szerint alakultak a vállalatok esetében:

16. táblázat: A projektvezetési szemléletmód megoszlása vállalatok szerint

\begin{tabular}{|c|c|c|c|c|}
\hline & $\begin{array}{l}\text { Projektfolyamat- } \\
\text { centrikus }\end{array}$ & $\begin{array}{l}\text { Érintett- } \\
\text { centrikus }\end{array}$ & $\begin{array}{l}\text { Projektfolyamat- } \\
\text { centrikus, } \\
\text { érintett-centrikus }\end{array}$ & $\begin{array}{l}\text { Stratégia- } \\
\text { orientált }\end{array}$ \\
\hline $\begin{array}{l}1 . \\
\text { vállalat }\end{array}$ & 3 & 5 & 1 & 0 \\
\hline $\begin{array}{l}2 . \\
\text { vállalat }\end{array}$ & 1 & 3 & 0 & 1 \\
\hline $\begin{array}{l}3 . \\
\text { vállalat }\end{array}$ & 2 & 2 & 0 & 2 \\
\hline $\begin{array}{l}4 . \\
\text { vállalat }\end{array}$ & 2 & 0 & 0 & 0 \\
\hline
\end{tabular}




\begin{tabular}{|l|r|r|r|r|} 
5. & & & & \\
vállalat & 0 & 3 & 1 & 2 \\
Összesen & 8 & 13 & 2 & 5 \\
\hline
\end{tabular}

Forrás: saját szerkesztés

A 16. táblázat alapján leszürhető, hogy a 4. vállalat esetén a projektolyamatcentrikusság a domináns projektvezetési szemléletmód. Ez valószínú részben az agilis projektvezetési eljárás alkalmazásának magas foka miatt van (azonban ez magával vonzaná az érintett-centrikus megközelitést is, de ezt még nem vallják maguknak a projektvezetők [vö. Aljaz, 2013]).

Megállapítható továbbá, hogy a legtöbben érintett-centrikus magatartást követnek. Ennek oka valószínủ az agilis projektvezetési eljárás alkalmazása, az iparági jellemzők és a vállalati jellemzők. Második leggyakoribb a projektfolyamatcentrikus megközelítés, ennek magyarázata lehet a klasszikus projektvezetési eljárások projektfolyamat-centrikus szemléletmódja (vö. International Project Management Association, 2006; Project Management Institute, 2008). A stratégiaorientált megközelítés nem gyakori a projektvezetők között, köszönhetöen annak, hogy ehhez vagy jelentős tapasztalat és ebböl kifolyólag komoly pozíció vagy támogató vállalati kultúra szükséges. Ennek fényében a 3 . és az 5 . vállalat rendelkezik megfelelő kultúrával és/vagy magasan képzett projektvezetők kerültek megkérdezésre (vö.16. táblázat).

A második hipotézis elfogadásához vagy elvetéséhez szükséges volt még azt is megkérdezni, hogy az azonosított szemléletmód szerint alkalmazza-e a projektvezetési eszközöket, és szerinte az eszközök alkalmazásának módja fejlődötte/finomodott-e a szakmai pályafutása során, valamint azt, hogy ezek az eszközök inkább megtanulhatóak-e vagy elsajátíthatóak-e. Az eredményeket az alábbi táblázat foglalja össze: 
17. táblázat: A projektvezetői szemléletmód és a tudás kapcsolata

\begin{tabular}{|c|c|c|c|c|c|}
\hline & & $\begin{array}{l}\text { Projektvezetői } \\
\text { szemléletmód }\end{array}$ & $\begin{array}{l}\text { Ez alapján a } \\
\text { szemléletmód } \\
\text { alapján } \\
\text { alkalmazza-e } \\
\text { az eszközeit? }\end{array}$ & $\begin{array}{l}\text { Szerinte } \\
\text { fejlődtek-e ezek } \\
\text { az eszközök } \\
\text { alkalmazásának } \\
\text { módja az évek } \\
\text { során? }\end{array}$ & $\begin{array}{l}\text { Szerinte } \\
\text { inkább } \\
\text { elsajátítható } \\
\text { vagy } \\
\text { megtanulható } \\
?\end{array}$ \\
\hline \multirow{9}{*}{$\begin{array}{c}1 . \\
\text { vállalat }\end{array}$} & 1. interjúalany & érintett-centrikus & igen & igen & elsajátítható \\
\hline & 2. interjúalany & érintett-centrikus & igen & igen & elsajátítható \\
\hline & 4. interjúalany & érintett-centrikus & igen & igen & elsajátítható \\
\hline & 5. interjúalany & érintett-centrikus & igen & igen & elsajátítható \\
\hline & 6. interjúalany & $\begin{array}{l}\text { projektfolyamat- } \\
\text { centrikus }\end{array}$ & igen & igen & elsajátítható \\
\hline & 7. interjúalany & $\begin{array}{l}\text { projektfolyamat- } \\
\text { centrikus }\end{array}$ & igen & igen & elsajátítható \\
\hline & 8. interjúalany & $\begin{array}{l}\text { stratégia- } \\
\text { orientáltság }\end{array}$ & igen & igen & elsajátítható \\
\hline & 9. interjúalany & $\begin{array}{l}\text { projektfolyamat- } \\
\text { centrikus }\end{array}$ & igen & igen & elsajátítható \\
\hline & $\begin{array}{l}10 . \\
\text { interjúalany }\end{array}$ & $\begin{array}{l}\text { projektfolyamat- } \\
\text { centrikus, } \\
\text { érintett-centrikus }\end{array}$ & igen & igen & elsajátítható \\
\hline
\end{tabular}




\begin{tabular}{|c|c|c|c|c|c|}
\hline & $\begin{array}{l}11 . \\
\text { interjúalany }\end{array}$ & érintett-centrikus & igen & igen & elsajátítható \\
\hline \multirow{5}{*}{$\begin{array}{c}2 . \\
\text { vállalat }\end{array}$} & $\begin{array}{l}12 . \\
\text { interjúalany }\end{array}$ & érintett-centrikus & igen & igen & elsajátítható \\
\hline & $\begin{array}{l}13 . \\
\text { interjúalany }\end{array}$ & érintett-centrikus & igen & nem & elsajátítható \\
\hline & $\begin{array}{l}14 . \\
\text { interjúalany }\end{array}$ & $\begin{array}{l}\text { stratégia- } \\
\text { orientáltság }\end{array}$ & igen & igen & elsajátítható \\
\hline & $\begin{array}{l}15 . \\
\text { interjúalany }\end{array}$ & érintett-centrikus & igen & igen & elsajátítható \\
\hline & $\begin{array}{l}16 . \\
\text { interjúalany }\end{array}$ & $\begin{array}{l}\text { projektfolyamat- } \\
\text { centrikus }\end{array}$ & igen & igen & elsajátítható \\
\hline \multirow{6}{*}{$\begin{array}{c}3 . \\
\text { vállalat }\end{array}$} & $\begin{array}{l}18 . \\
\text { interjúalany }\end{array}$ & érintett-centrikus & igen & igen & elsajátítható \\
\hline & $\begin{array}{l}19 . \\
\text { interjúalany }\end{array}$ & érintett-centrikus & igen & igen & elsajátítható \\
\hline & $\begin{array}{l}20 . \\
\text { interjúalany }\end{array}$ & $\begin{array}{l}\text { projektfolyamat- } \\
\text { centrikus }\end{array}$ & - & - & - \\
\hline & $\begin{array}{l}21 . \\
\text { interjúalany }\end{array}$ & $\begin{array}{l}\text { stratégia- } \\
\text { orientáltság }\end{array}$ & igen & igen & elsajátítható \\
\hline & $\begin{array}{l}22 . \\
\text { interjúalany }\end{array}$ & $\begin{array}{l}\text { stratégia- } \\
\text { orientáltság }\end{array}$ & igen & igen & elsajátítható \\
\hline & $\begin{array}{l}23 . \\
\text { interjúalany }\end{array}$ & $\begin{array}{l}\text { projektfolyamat- } \\
\text { centrikus }\end{array}$ & igen & igen & elsajátítható \\
\hline
\end{tabular}




\begin{tabular}{|c|c|c|c|c|c|}
\hline \multirow{2}{*}{$\begin{array}{c}4 . \\
\text { vállalat }\end{array}$} & $\begin{array}{l}24 . \\
\text { interjúalany }\end{array}$ & $\begin{array}{l}\text { projektfolyamat- } \\
\text { centrikus }\end{array}$ & igen & igen & elsajátítható \\
\hline & $\begin{array}{l}25 . \\
\text { interjúalany }\end{array}$ & $\begin{array}{l}\text { projektfolyamat- } \\
\text { centrikus }\end{array}$ & igen & igen & elsajátítható \\
\hline \multirow{6}{*}{$\begin{array}{c}5 . \\
\text { vállalat }\end{array}$} & $\begin{array}{l}26 . \\
\text { interjúalany }\end{array}$ & érintett-centrikus & igen & igen & elsajátítható \\
\hline & $\begin{array}{l}27 . \\
\text { interjúalany }\end{array}$ & $\begin{array}{l}\text { stratégia- } \\
\text { orientáltság }\end{array}$ & igen & igen & elsajátítható \\
\hline & $\begin{array}{l}28 . \\
\text { interjúalany }\end{array}$ & $\begin{array}{l}\text { stratégia- } \\
\text { orientáltság }\end{array}$ & igen & igen & elsajátítható \\
\hline & $\begin{array}{l}29 . \\
\text { interjúalany }\end{array}$ & $\begin{array}{l}\text { projektfolyamat- } \\
\text { centrikus, } \\
\text { érintett-centrikus }\end{array}$ & igen & igen & elsajátítható \\
\hline & $\begin{array}{l}30 . \\
\text { interjúalany }\end{array}$ & érintett-centrikus & igen & igen & elsajátítható \\
\hline & $\begin{array}{l}31 . \\
\text { interjúalany }\end{array}$ & érintett-centrikus & igen & igen & elsajátítható \\
\hline
\end{tabular}

Forrás: saját szerkesztés 
A projektvezetők mindegyike a korábban beazonosított projektvezetési szemléletmód alapján alkalmazza a projektvezetési eszközöket (kivéve egyet, aki nem válaszolt). Továbbá egyetlen projektvezető szerint nem fejlődtek a projektvezetési eszközeinek alkalmazásának módja az évek során. A többiek esetében fejlődött. Ez magyarázható azzal, hogy jobban, nagyobb hatásfokkal, esetleg fejlesztett tartalommal, személyre szabottan tudja alkalmazni a projektvezetési eszközöket. Végezetül pedig minden projektvezető egyetértett abban, hogy az eszközök inkább elsajátíthatók, bár 9 projektvezető kiemelte az oktatás fontosságát, azaz szükségesnek találták az elméleti alapot. Valószínüsíthetően a többiek esetén is igaz az, hogy elméleti alap nélkül csak viszontagságosan tudta volna vezetni a projektjeit, azonban ők sokkal fontosabbnak érezték az évek során vagy egyéb módon megszerzett tapasztalatot, olyannyira, hogy az oktatás szerepét minimálisnak ítélték .

Mindennek fényében kijelenthető, hogy amennyiben elfogadjuk azt, hogy a tacit tudás átadása nehézkes, és inkább gyakorlat közben szerzi meg az ember a szükséges tudást (azaz elsajátítható, semmint tanulható), vagy olyan környezetben, ahol a gyakorlat képeződik le (vö. Horváth, 2013), akkor megállapítható, minden projektvezető úgy gondolja, hogy a tacit elemek fontosabbak a projektvezetés során.

Az eredmények függvényében megállapítható, hogy a második hipotézis, azaz hogy az explicit tudás nagyobb mértékben van jelen a projektvezető projektvezetési szemléletében, mint az explicit, elvethető.

Ez az eredmény önmagában azt vetíti előre, hogy az olyan egyetemi kurzusoknak, amelyek projektmenedzsmenttel kapcsolatosak, azt kell kitüzni célnak, hogy az elméleti alap mellett képezzen olyan környezetet, ahol a tacit tudásátadásra sor kerülhet.

\subsubsection{Az azonosított projektvezetési szemléletmód projektsikerre gyakorolt hatásának kimutatása}

A kutatás harmadik része a projektvezetési szemléletmód hatását hivatott feltérképezni. Ahogy korábban említésre került, a kutatásnak nem része a hatás mértékének kimutatása, hanem az, hogy a projektvezetési szemléletmód egyáltalán 
hatással van-e az elérendő projektsikerre. A projektsiker pedig a hierarchikus modell tükrében lett vizsgálva. Ezért ez a rész is három részre bomlik, azaz az alkalmazott projektvezetési szemléletmód hatással van-e a projektháromszög szerinti sikerességre, hatással van-e a projekttulajdonosi megelégedettség szerinti sikeressége és hatással van-e az egyéb érintettek megelégedettsége szerinti sikeresség elérésére. A válaszok relevanciájának növelése érdekében nem csak az lett megkérdezve, hogy a projektvezető szerint gyakorol-e hatást a szemléletmódja az adott sikerszintre, hanem az is, hogy szerinte miként.

A projektháromszög szerinti sikerességre gyakorolt hatásra adott válaszokat 18. táblázat foglalja össze: 
18. táblázat: A projektvezetési szemléletmód hatása a projektháromszög szerinti sikerességre

\begin{tabular}{|c|c|c|c|c|}
\hline \multicolumn{2}{|c|}{$\begin{array}{l}\text { Projektháromszög } \\
\text { szerinti sikeresség }\end{array}$} & $\begin{array}{l}\text { Projektvezetői } \\
\text { szemléletmód }\end{array}$ & $\begin{array}{l}\text { Szerinte hatást } \\
\text { gyakorol-e az } \\
\text { alkalmazott } \\
\text { projektvezetési } \\
\text { szemléletmód a } \\
\text { projektsiker erre } \\
\text { az aspektusára? }\end{array}$ & $\begin{array}{l}\text { Szerinte miként } \\
\text { gyakorol hatást } \\
\text { (ha gyakorol) az } \\
\text { alkalmazott } \\
\text { projektvezetési } \\
\text { szemléletmód a } \\
\text { projektsiker erre } \\
\text { az aspektusára? }\end{array}$ \\
\hline \multirow{5}{*}{$\begin{array}{c}1 . \\
\text { vállalat }\end{array}$} & 1. interjúalany & érintett-centrikus & igen & $\begin{array}{l}\text { projektcsapat jobb } \\
\text { motiváltsága révén }\end{array}$ \\
\hline & 2. interjúalany & érintett-centrikus & igen & $\begin{array}{l}\text { erőforrás-elosztás és } \\
\text { kommunikáció révén }\end{array}$ \\
\hline & 4. interjúalany & érintett-centrikus & igen & $\begin{array}{l}\text { kollégákkal a } \\
\text { kölcsönösség elvén } \\
\text { végzi a munkát, így } \\
\text { partnerség létrehozása }\end{array}$ \\
\hline & 5. interjúalany & érintett-centrikus & igen & $\begin{array}{l}\text { projekttervek } \\
\text { optimalizálás révén }\end{array}$ \\
\hline & 6. interjúalany & $\begin{array}{l}\text { projektfolyamat- } \\
\text { centrikus }\end{array}$ & igen & $\begin{array}{l}\text { alapos tervezés révén a } \\
\text { kockázatok } \\
\text { kiküszöbölése }\end{array}$ \\
\hline
\end{tabular}




\begin{tabular}{|c|c|c|c|c|}
\hline & 7. interjúalany & $\begin{array}{l}\text { projektfolyamat- } \\
\text { centrikus }\end{array}$ & igen & $\begin{array}{l}\text { jó struktúra, tervezés } \\
\text { összhangban a vevői } \\
\text { igényekkel, bár így a } \\
\text { tervezés hosszabb, de } \\
\text { ez megtérül }\end{array}$ \\
\hline & 8. interjúalany & stratégia-orientáltság & $\begin{array}{l}\text { igen (segíthet és } \\
\text { gátolhat is) }\end{array}$ & $\begin{array}{l}\text { ha a termék számít, } \\
\text { akkor segít, ha a } \\
\text { személyes kapcsolat, } \\
\text { akkor nem annyira }\end{array}$ \\
\hline & 9. interjúalany & $\begin{array}{l}\text { projektfolyamat- } \\
\text { centrikus }\end{array}$ & igen & $\begin{array}{l}\text { fontos a cél kitüzése, } \\
\text { tervezése }\end{array}$ \\
\hline & $\begin{array}{l}10 . \\
\text { interjúalany }\end{array}$ & $\begin{array}{l}\text { projektfolyamat- } \\
\text { centrikus, } \\
\text { érintett-centrikus }\end{array}$ & igen & $\begin{array}{l}\text { projektcsapat jobb } \\
\text { motiváltsága révén }\end{array}$ \\
\hline & $\begin{array}{l}11 . \\
\text { interjúalany }\end{array}$ & érintett-centrikus & igen & $\begin{array}{l}\text { projektcsapat jobb } \\
\text { motiváltsága révén }\end{array}$ \\
\hline \multirow{4}{*}{$\begin{array}{c}2 . \\
\text { vállalat }\end{array}$} & $\begin{array}{l}12 . \\
\text { interjúalany }\end{array}$ & érintett-centrikus & igen & $\begin{array}{l}\text { tervezés és környezet } \\
\text { figyelembe vétele }\end{array}$ \\
\hline & $\begin{array}{l}13 . \\
\text { interjúalany }\end{array}$ & érintett-centrikus & igen & folyamatos kooperáció \\
\hline & $\begin{array}{l}14 . \\
\text { interjúalany }\end{array}$ & stratégia-orientáltság & igen & $\begin{array}{l}\text { minőségre hat főként a } \\
\text { projektcsapat jobb } \\
\text { ösztönzése által }\end{array}$ \\
\hline & 15. & érintett-centrikus & igen & jól definiált feladat (jó \\
\hline
\end{tabular}




\begin{tabular}{|c|c|c|c|c|}
\hline & interjúalany & & & tervezés) \\
\hline & $\begin{array}{l}16 . \\
\text { interjúalany }\end{array}$ & $\begin{array}{l}\text { projektfolyamat- } \\
\text { centrikus }\end{array}$ & igen & $\begin{array}{l}\text { értékteremtés révén, és } \\
\text { ennek kommunikációja }\end{array}$ \\
\hline \multirow{6}{*}{$\begin{array}{c}3 . \\
\text { vállalat }\end{array}$} & $\begin{array}{l}18 . \\
\text { interjúalany }\end{array}$ & érintett-centrikus & igen & jó együttmüködés \\
\hline & $\begin{array}{l}19 . \\
\text { interjúalany }\end{array}$ & érintett-centrikus & igen & $\begin{array}{l}\text { motiválás és bevonás } \\
\text { révén }\end{array}$ \\
\hline & $\begin{array}{l}20 . \\
\text { interjúalany }\end{array}$ & $\begin{array}{l}\text { projektfolyamat- } \\
\text { centrikus }\end{array}$ & igen & $\begin{array}{l}\text { tervezés és a } \\
\text { projekttervek } \\
\text { optimalizálás }\end{array}$ \\
\hline & $\begin{array}{l}21 . \\
\text { interjúalany }\end{array}$ & stratégia-orientáltság & igen & $\begin{array}{l}\text { proaktivitás és } \\
\text { motiválás }\end{array}$ \\
\hline & $\begin{array}{l}22 . \\
\text { interjúalany }\end{array}$ & stratégia-orientáltság & néha & - \\
\hline & $\begin{array}{l}23 . \\
\text { interjúalany }\end{array}$ & $\begin{array}{l}\text { projektfolyamat- } \\
\text { centrikus }\end{array}$ & igen & tervezés \\
\hline \multirow{2}{*}{$\begin{array}{c}4 . \\
\text { vállalat }\end{array}$} & $\begin{array}{l}24 . \\
\text { interjúalany }\end{array}$ & $\begin{array}{l}\text { projektfolyamat- } \\
\text { centrikus }\end{array}$ & igen & $\begin{array}{l}\text { priorizálás és a } \\
\text { projekttervek } \\
\text { optimalizálás révén }\end{array}$ \\
\hline & $\begin{array}{l}25 . \\
\text { interjúalany }\end{array}$ & $\begin{array}{l}\text { projektfolyamat- } \\
\text { centrikus }\end{array}$ & $\begin{array}{l}\text { nincs közvetlen } \\
\text { összefüggés }\end{array}$ & - \\
\hline $\begin{array}{c}5 . \\
\text { vállalat }\end{array}$ & $\begin{array}{l}26 . \\
\text { interjúalany }\end{array}$ & érintett-centrikus & igen & $\begin{array}{l}\text { a projekttervek } \\
\text { optimalizálás és } \\
\text { priorizálás }\end{array}$ \\
\hline
\end{tabular}




\begin{tabular}{|l|l|l|l|l|}
$\begin{array}{l}27 . \\
\text { interjúalany }\end{array}$ & stratégia-orientáltság & igen & priorizálás és motiválás \\
\hline $\begin{array}{l}\mathbf{2 8 .} \\
\text { interjúalany }\end{array}$ & stratégia-orientáltság & igen & - \\
\hline $\begin{array}{l}\mathbf{2 9 .} \\
\text { interjúalany }\end{array}$ & $\begin{array}{l}\text { projektfolyamat- } \\
\text { centrikus, } \\
\text { érintett-centrikus }\end{array}$ & nem & - \\
\hline $\begin{array}{l}\text { 30. } \\
\text { interjúalany }\end{array}$ & érintett-centrikus & igen & motiváció \\
\hline $\begin{array}{l}\text { 31. } \\
\text { interjúalany }\end{array}$ & érintett-centrikus & igen & $\begin{array}{l}\text { rendszerben kezelés } \\
\text { (terv, érintett) }\end{array}$ \\
\hline
\end{tabular}

Forrás: saját szerkesztés 
A 18. táblázatból megállapítható, hogy a projektvezetők döntő többsége szerint hatást gyakorol a projektháromszög szerinti sikerességre a projektvezetési szemléletmód. Csupán két projektvezető szerint nem, míg egy projektvezető gondolta úgy, hogy a projektvezetési szemléletnek csupán néha van hatása a projektsikerre. Ketten pedig nem indokolták meg, hogy az általuk képviselt szemléletmód minek révén hat a sikerre. Megállapítható továbbá az is, hogy a projektfolyamat-centrikus megközelítést vallók közül a legtöbben a pontos tervezéssel indokolják a projektsiker projektháromszög szerint értelmezett siker teljesülésének elősegítését, míg az érintett-centrikus megközelítés a megfelelően motivált projektcsapatra helyezi a hangsúlyt, a stratégia-orientáltak pedig a priorizálásra és proaktivitásra. Ez egybevág az elméleti megközelítéssel, hiszen ha a projektvezetésre mint folyamat vezetésére tekint a projektvezető, akkor a projekttervezés, kontroll, optimalizálás válik hangsúlyossá, ha a projektvezetésre mint az ideiglenes szervezet vezetésére tekint (különösen a projektcsapatéra), akkor a érintettek kezelése válik igen hangsúlyossá, ha pedig a projektvezetésre mint stratégiai építőelemre tekint, akkor a kedvező változás létrehozása a fó fókusz, és így a megfelelő tervezés és a vevői igények szem előtt tartása válik hangsúlyossá. Természetesen ez nem azt jelenti, hogy más projektvezetési eszközöket ne használnának fel. Megfigyelhető, hogy azok, akik stratégia-orientált magatartást követnek (és adtak választ), egy kivételével a projektcsapat motivációját is fontosnak tartják. Megállapítható ezek mellett az is, hogy az 5., 15., 20 és némiképp a 31. interjúalany - bár érintett-centrikusnak vallották magukat - a projekttervezésre helyezi a hangsúlyt, ami némiképp ellentmond a korábban azonosított szemléletmódjukkal, és azt sejteti, hogy a projektvezetési szemléletmódjába óhatatlanul projektfolyamat-centrikus elemek is vegyülnek. Hasonló eredményt tapasztalhatunk a 8 . interjúalanynál, bár ebben az esetben az ellentmondás csak látszólagos. A stratégia-orientált szemléletmód nem követeli meg a rendszeres kommunikációt, így a hangsúly helyeződhet a megfelelően körültekintett projekttervezésre is (a vevői igényekkel összhangban), ezért az ő válaszát megfelelőnek lehet ítélni. Azonban a többi interjúalany a szemléletmódjával összhangban használja a projektvezetési eszközöket, így megállapítható, hogy az azonosításra került szemléletmódjukat ez az eredmény mintegy utólag igazolja. 
Amennyiben a projektsiker projektháromszög szerinti aspektusára gyakorolt hatás kerül vizsgálatra, akkor - kiszürve a nem megfelelő válaszokat megállapítható, hogy 21 projektvezető tartotta úgy (megfelelő indoklással), hogy a szemléletmód hatást gyakorol a projektháromszög szerint értelmezett projektsikerre, kettő gondolta úgy, hogy nem, egy pedig úgy, hogy néha. Ráadásul akik szerint hatást gyakorol, egy kivételével mindenki úgy tartotta, hogy a hatás iránya pozitív, míg csupán egy tartotta úgy, hogy a hatás kétirányú. Egyetlen projektvezető sem tartotta úgy, hogy a hatás negatív lenne, bár kiemelték többen (a 2-es, a 20-as és a 26-os), hogy projektháromszög szerint értelmezett projektsiker egyes elemeire való hatása helyzetfüggő (pl. a költség megnövekedése révén tudja biztosítani a többit).

Összefoglalva megállapítható tehát, hogy 21 projektvezető tartotta úgy, a projektvezetési szemléletmód hatást gyakorol a projektsiker projektháromszög szerinti sikeraspektusára, míg csupán kettő tartotta úgy, hogy nem, ezért a harmadik hipotézis első része elfogadható.

A második lépés ezen a részen belül a projektvezetési szemléletmód projekttulajdonosi elégedettség szerinti projektsiker szerint értelmezett projektsikerre gyakorolt hatásának feltérképezése volt. Hasonlóan a projektháromszög szerinti sikerértelmezéshez, itt is megkérdezésre került nem csak az, hogy gyakorol-e hatást, hanem az is, hogy miként gyakorol hatást. A válaszokat a 19. táblázat összegzi: 
19. táblázat: A projektvezetési szemléletmód hatása a projekttulajdonosi elégedettség szerinti sikerességre

\begin{tabular}{|c|c|c|c|c|}
\hline \multicolumn{2}{|c|}{$\begin{array}{l}\text { Projekttulajdonosi } \\
\text { elégedettség szerinti } \\
\text { sikeresség }\end{array}$} & $\begin{array}{l}\text { Projektvezetői } \\
\text { szemléletmód }\end{array}$ & $\begin{array}{l}\text { Szerinte hatást } \\
\text { gyakorol-e az } \\
\text { alkalmazott } \\
\text { projektvezetési } \\
\text { szemléletmód a } \\
\text { projektsiker erre } \\
\text { az aspektusára? }\end{array}$ & $\begin{array}{l}\text { Szerinte miként } \\
\text { gyakorol hatást (ha } \\
\text { gyakorol) az } \\
\text { alkalmazott } \\
\text { projektvezetési } \\
\text { szemléletmód a } \\
\text { projektsiker erre } \\
\text { az aspektusára? }\end{array}$ \\
\hline \multirow{5}{*}{$\begin{array}{c}1 . \\
\text { vállalat }\end{array}$} & 1. interjúalany & érintett-centrikus & igen & $\begin{array}{l}\text { kommunikáció } \\
\text { (vevővel) }\end{array}$ \\
\hline & 2. interjúalany & érintett-centrikus & igen & $\begin{array}{l}\text { kommunikáció } \\
\text { (vevővel), } \\
\text { kompromisszumok, } \\
\text { maximális szolgáltatás } \\
\text { (extrák, pl. ingyen } \\
\text { oktatás) }\end{array}$ \\
\hline & 4. interjúalany & érintett-centrikus & igen & $\begin{array}{l}\text { azáltal, hogy minden } \\
\text { rendben megy } \\
\text { (személyi oldalról is) }\end{array}$ \\
\hline & 5. interjúalany & érintett-centrikus & igen & $\begin{array}{l}\text { partneri kapcsolat, } \\
\text { gesztusok }\end{array}$ \\
\hline & 6. interjúalany & projektfolyamat- & igen & a projekt \\
\hline
\end{tabular}




\begin{tabular}{|c|c|c|c|c|}
\hline & & centrikus & & megalapozottsága révén \\
\hline & 7. interjúalany & $\begin{array}{l}\text { projektfolyamat- } \\
\text { centrikus }\end{array}$ & igen & $\begin{array}{l}\text { egyensúly az érintettek } \\
\text { kezelése és tartalom } \\
\text { között }\end{array}$ \\
\hline & 8. interjúalany & stratégia-orientáltság & $\begin{array}{l}\text { igen (segíthet és } \\
\text { gátolhat is) }\end{array}$ & $\begin{array}{l}\text { ha a termék számít, } \\
\text { akkor segít, ha a } \\
\text { személyes kapcsolat, } \\
\text { akkor nem annyira }\end{array}$ \\
\hline & 9. interjúalany & $\begin{array}{l}\text { projektfolyamat- } \\
\text { centrikus }\end{array}$ & igen & kommunikáció \\
\hline & $\begin{array}{l}10 . \\
\text { interjúalany }\end{array}$ & $\begin{array}{l}\text { projektfolyamat- } \\
\text { centrikus, } \\
\text { érintett-centrikus } \\
\end{array}$ & igen & $\begin{array}{l}\text { gyors szállítás, } \\
\text { őszinteség }\end{array}$ \\
\hline & $\begin{array}{l}11 . \\
\text { interjúalany }\end{array}$ & érintett-centrikus & igen & $\begin{array}{l}\text { „soft skillek” (pl. } \\
\text { kiállás, érintettek } \\
\text { megfelelő kezelése) } \\
\text { révén }\end{array}$ \\
\hline \multirow{4}{*}{$\begin{array}{c}2 . \\
\text { vállalat }\end{array}$} & $\begin{array}{l}12 . \\
\text { interjúalany }\end{array}$ & érintett-centrikus & igen & $\begin{array}{l}\text { alkalmazkodás és ennek } \\
\text { megvalósítása }\end{array}$ \\
\hline & $\begin{array}{l}13 . \\
\text { interjúalany }\end{array}$ & érintett-centrikus & részben & projekteredmény révén \\
\hline & $\begin{array}{l}14 . \\
\text { interjúalany }\end{array}$ & stratégia-orientáltság & igen & $\begin{array}{l}\text { alternatívák } \\
\text { érzékeltetése }\end{array}$ \\
\hline & $\begin{array}{l}15 . \\
\text { interjúalany }\end{array}$ & érintett-centrikus & igen & $\begin{array}{l}\text { folyamatos jelentés, } \\
\text { kommunikáció }\end{array}$ \\
\hline
\end{tabular}




\begin{tabular}{|c|c|c|c|c|}
\hline & $\begin{array}{l}16 . \\
\text { interjúalany }\end{array}$ & $\begin{array}{l}\text { projektfolyamat- } \\
\text { centrikus }\end{array}$ & igen & értékteremtés \\
\hline \multirow{6}{*}{$\begin{array}{c}3 . \\
\text { vállalat }\end{array}$} & \begin{tabular}{|l}
18. \\
interjúalany
\end{tabular} & érintett-centrikus & igen & $\begin{array}{l}\text { kontroll és } \\
\text { kommunikáció }\end{array}$ \\
\hline & $\begin{array}{l}19 . \\
\text { interjúalany }\end{array}$ & érintett-centrikus & igen & $\begin{array}{l}\text { érdekképviselet, } \\
\text { üzleties szemlélet }\end{array}$ \\
\hline & $\begin{array}{l}20 . \\
\text { interjúalany }\end{array}$ & $\begin{array}{l}\text { projektfolyamat- } \\
\text { centrikus }\end{array}$ & igen & elvárás teljesítése \\
\hline & $\begin{array}{l}21 . \\
\text { interjúalany }\end{array}$ & stratégia-orientáltság & igen & $\begin{array}{l}\text { motivált projektcsapat } \\
\text { révén a } \\
\text { projekteredmény } \\
\text { teljesítése, proaktivitás }\end{array}$ \\
\hline & $\begin{array}{l}22 . \\
\text { interjúalany } \\
\end{array}$ & stratégia-orientáltság & igen & $\begin{array}{l}\text { észrevételek, kritikai } \\
\text { elemzés a projektről }\end{array}$ \\
\hline & \begin{tabular}{|l}
23. \\
interjúalany
\end{tabular} & $\begin{array}{l}\text { projektfolyamat- } \\
\text { centrikus }\end{array}$ & igen & tervek révén \\
\hline \multirow{2}{*}{$\begin{array}{c}4 . \\
\text { vállalat }\end{array}$} & $\begin{array}{l}24 . \\
\text { interjúalany }\end{array}$ & $\begin{array}{l}\text { projektfolyamat- } \\
\text { centrikus }\end{array}$ & igen & $\begin{array}{l}\text { megkapja azt a } \\
\text { projekteredményt, amit } \\
\text { szeretne }\end{array}$ \\
\hline & \begin{tabular}{|l}
25. \\
interjúalany
\end{tabular} & $\begin{array}{l}\text { projektfolyamat- } \\
\text { centrikus }\end{array}$ & igen & $\begin{array}{l}\text { a jó minőségü termék } \\
\text { révén }\end{array}$ \\
\hline 5. & $\begin{array}{l}26 . \\
\text { interjúalany }\end{array}$ & érintett-centrikus & igen & érdek figyelembe vétele \\
\hline
\end{tabular}




\begin{tabular}{|c|c|c|c|c|}
\hline \multirow[t]{5}{*}{ vállalat } & $\begin{array}{l}27 . \\
\text { interjúalany }\end{array}$ & stratégia-orientáltság & igen & $\begin{array}{l}\text { termék révén, } \\
\text { szolgáltatást ad nem, } \\
\text { csak terméket (pl. } \\
\text { megfelelö figyelmet } \\
\text { szán a } \\
\text { kommunikációra, } \\
\text { gesztusokra) }\end{array}$ \\
\hline & \begin{tabular}{|l}
28. \\
interjúalany
\end{tabular} & stratégia-orientáltság & igen & $\begin{array}{l}\text { az érintettek érdekének } \\
\text { figyelembe vétele }\end{array}$ \\
\hline & $\begin{array}{l}29 . \\
\text { interjúalany }\end{array}$ & $\begin{array}{l}\text { projektfolyamat- } \\
\text { centrikus, } \\
\text { érintett-centrikus }\end{array}$ & nem & - \\
\hline & \begin{tabular}{|l}
30. \\
interjúalany
\end{tabular} & érintett-centrikus & igen & $\begin{array}{l}\text { termék és } \\
\text { kommunikáció }\end{array}$ \\
\hline & $\begin{array}{l}31 . \\
\text { interjúalany }\end{array}$ & érintett-centrikus & igen & $\begin{array}{l}\text { üzleti környezet } \\
\text { figyelembe vétele }\end{array}$ \\
\hline
\end{tabular}

Forrás: saját szerkesztés 
A válaszok alapján megállapítható, hogy a választ adó projektvezetők válasza összhangban van az alkalmazott projektvezetési szemléletmódjával, kivéve a 9., a 13. és némiképp a 31. interjúalanyt. A projektfolyamat-centrikus megközelítés - az elmélet alapján - azt sejtetné, hogy a projektteljesítést helyezi a középpontba, így a megfelelő termék leszállítása révén igyekszik a projekttulajdonosi elégedettséget biztosítani, az érintett-centrikus megközelítés a megfelelö érintettek kezelése révén, míg a stratégia-orientált megközelítés az üzleties szemlélet (proaktivitás, alternatívák elemzése) révén. Ezzel szemben a két projektvezető nem a projektvezetési szemléletmódjának megfelelő választ adott, 9. interjúalany a kommunikációra helyezi a fő hangsúlyt, míg a 13. a projekteredményre. Természetesen nem jelenthető ki, hogy az egyes szemléletmódok ne alkalmazhatnának atipikus eszközöket is, azonban amennyiben nem alkalmazza a projektvezető a szemléletmódjának megfelelő eszközt, akkor felmerülhet, hogy más szemléletmódot alkalmaz ennél az aspektusnál. Esetleg rosszul kategorizálta magát. A 31. projektvezető eszköze igen általános, hiszen a környezet figyelembe vételébe beletartozik a projektcsapat és a vevő is, így válasza - még akkor is, ha nem konkrét - relevánsnak tekinthető. Látszólagos ellentmondás lehet ismételten a 8 . interjúalany esetén, azonban a korábban megfogalmazott válasza (azaz vevői érdek a termékben) jelen esetben is helytálló.

Mindezek fényében megállapítható tehát, hogy 27 projektvezető válasza tekinthető relevánsnak. Ebböl a 27-ből 25 tartja úgy, hogy a projektvezetési szemléletmódja hatással van a projektsiker projekttulajdonosi elégedettség szerinti aspektusra, méghozzá 24 ebből a 25-ből pozitívan értelmezi a hatást, egy pedig helyzettől függőnek. Egy projektvezető tartja úgy, hogy az általa vallott projektvezetési szemléletmódnak részben van csak hatása, míg egy projektvezető szerint nincs hatása.

Ezek alapján a harmadik hipotézis második része elfogadható.

A harmadik lépés ebben a részben a projektvezetési szemléletmód egyéb érintettek szerinti sikerességre gyakorolt hatásának vizsgálata volt. Hasonlóan a két korábbi alrészhez, nem csupán az lett megkérdezve, hogy gyakorol-e hatást, hanem az is, hogy milyen módon teszi mindezt. Így a nem megfelelő válaszok jobban 
kiszürhetőek voltak. A projektvezetők által adott válaszokat a 20. táblázat foglalja össze: 
20. táblázat: A projektvezetési szemléletmód hatása az érintettek elégedettsége szerinti sikerességre

\begin{tabular}{|c|c|c|c|c|}
\hline \multicolumn{2}{|c|}{$\begin{array}{c}\text { Érintettek } \\
\text { elégedettsége szerinti } \\
\text { sikeresség }\end{array}$} & $\begin{array}{l}\text { Projektvezetői } \\
\text { szemléletmód }\end{array}$ & $\begin{array}{l}\text { Szerinte hatást } \\
\text { gyakorol-e az } \\
\text { alkalmazott } \\
\text { projektvezetési } \\
\text { szemléletmód a } \\
\text { projektsiker erre a } \\
\text { aspektusára? }\end{array}$ & $\begin{array}{l}\text { Szerinte miként } \\
\text { gyakorol hatást (ha } \\
\text { gyakorol) az } \\
\text { alkalmazott } \\
\text { projektvezetési } \\
\text { szemléletmód a } \\
\text { projektsiker erre a } \\
\text { aspektusára? }\end{array}$ \\
\hline \multirow{6}{*}{$\begin{array}{c}1 . \\
\text { vállalat }\end{array}$} & 1. interjúalany & érintett-centrikus & igen & kommunikáció \\
\hline & 2. interjúalany & érintett-centrikus & igen (negatívan) & $\begin{array}{l}\text { a projekt minél } \\
\text { gyorsabb teljesítése } \\
\text { fontos lenne a } \\
\text { végfelhasználóknak, de } \\
\text { azt nem támogatja }\end{array}$ \\
\hline & 4. interjúalany & érintett-centrikus & igen & kölcsönösség révén \\
\hline & 5. interjúalany & érintett-centrikus & igen & kapcsolattartás, agilitás \\
\hline & 6. interjúalany & $\begin{array}{l}\text { projektfolyamat- } \\
\text { centrikus }\end{array}$ & igen & bevonás tervezésbe \\
\hline & 7. interjúalany & $\begin{array}{l}\text { projektfolyamat- } \\
\text { centrikus }\end{array}$ & nem & - \\
\hline
\end{tabular}




\begin{tabular}{|c|c|c|c|c|}
\hline & 8. interjúalany & stratégia-orientáltság & igen & $\begin{array}{l}\text { pajzsként szolgál az } \\
\text { érintettek számára } \\
\text { (föként projektcsapat } \\
\text { számára) }\end{array}$ \\
\hline & 9. interjúalany & $\begin{array}{l}\text { projektfolyamat- } \\
\text { centrikus }\end{array}$ & igen & kommunikáció \\
\hline & $\begin{array}{l}10 . \\
\text { interjúalany }\end{array}$ & $\begin{array}{l}\text { projektfolyamat- } \\
\text { centrikus, } \\
\text { érintett-centrikus }\end{array}$ & igen & $\begin{array}{l}\text { tesztelésre meghívás, } \\
\text { gesztusok (pl. idő } \\
\text { spórolása az } \\
\text { érintetteknek) }\end{array}$ \\
\hline & $\begin{array}{l}11 . \\
\text { interjúalany }\end{array}$ & érintett-centrikus & igen & $\begin{array}{l}\text { „soft skillek” (pl. } \\
\text { kiállás, érintettek } \\
\text { megfelelő kezelése) } \\
\text { révén }\end{array}$ \\
\hline \multirow{5}{*}{$\begin{array}{c}2 . \\
\text { vállalat }\end{array}$} & $\begin{array}{l}12 . \\
\text { interjúalany }\end{array}$ & érintett-centrikus & igen & $\begin{array}{l}\text { állandó kommunikáció, } \\
\text { transzparencia }\end{array}$ \\
\hline & $\begin{array}{l}13 . \\
\text { interjúalany }\end{array}$ & érintett-centrikus & igen & $\begin{array}{l}\text { állandó kommunikáció, } \\
\text { konszenzusok }\end{array}$ \\
\hline & $\begin{array}{l}14 . \\
\text { interjúalany }\end{array}$ & stratégia-orientáltság & igen & motiváció \\
\hline & $\begin{array}{l}15 . \\
\text { interjúalany }\end{array}$ & érintett-centrikus & igen & $\begin{array}{l}\text { könnyed munkavégzés, } \\
\text { jó kapcsolat }\end{array}$ \\
\hline & $\begin{array}{l}16 . \\
\text { interjúalany }\end{array}$ & $\begin{array}{l}\text { projektfolyamat- } \\
\text { centrikus }\end{array}$ & igen & $\begin{array}{l}\text { időben megkapja az } \\
\text { inputot mindenki }\end{array}$ \\
\hline
\end{tabular}




\begin{tabular}{|c|c|c|c|c|}
\hline \multirow{6}{*}{$\begin{array}{c}3 . \\
\text { vállalat }\end{array}$} & $\begin{array}{l}18 . \\
\text { interjúalany }\end{array}$ & érintett-centrikus & - & - \\
\hline & $\begin{array}{l}19 . \\
\text { interjúalany }\end{array}$ & érintett-centrikus & igen & $\begin{array}{l}\text { ösztönző környezet, } \\
\text { projektkarakterisztikák } \\
\text { (motiváló) }\end{array}$ \\
\hline & \begin{tabular}{|l}
20. \\
interjúalany
\end{tabular} & $\begin{array}{l}\text { projektfolyamat- } \\
\text { centrikus }\end{array}$ & igen & $\begin{array}{l}\text { példamutatás, } \\
\text { elkötelezettség }\end{array}$ \\
\hline & \begin{tabular}{|l}
21. \\
interjúalany
\end{tabular} & stratégia-orientáltság & igen & $\begin{array}{l}\text { proaktivitás, megfelelő } \\
\text { eszköz használata }\end{array}$ \\
\hline & $\begin{array}{l}22 . \\
\text { interjúalany }\end{array}$ & stratégia-orientáltság & nem & - \\
\hline & $\begin{array}{l}23 . \\
\text { interjúalany }\end{array}$ & $\begin{array}{l}\text { projektfolyamat- } \\
\text { centrikus }\end{array}$ & nem & - \\
\hline \multirow{2}{*}{$\begin{array}{c}4 . \\
\text { vállalat }\end{array}$} & $\begin{array}{l}24 . \\
\text { interjúalany }\end{array}$ & $\begin{array}{l}\text { projektfolyamat- } \\
\text { centrikus }\end{array}$ & igen & erőforrás-optimalizálás \\
\hline & $\begin{array}{l}25 . \\
\text { interjúalany }\end{array}$ & $\begin{array}{l}\text { projektfolyamat- } \\
\text { centrikus }\end{array}$ & igen & $\begin{array}{l}\text { döntések megfelelösége } \\
\text { révén }\end{array}$ \\
\hline \multirow[b]{2}{*}{$\begin{array}{c}5 . \\
\text { vállalat }\end{array}$} & \begin{tabular}{|l}
26. \\
interjúalany
\end{tabular} & érintett-centrikus & igen & érdek figyelembe vétele \\
\hline & $\begin{array}{l}27 . \\
\text { interjúalany }\end{array}$ & stratégia-orientáltság & igen & $\begin{array}{l}\text { végfelhasználók esetén } \\
\text { a projekteredmény } \\
\text { kiválósága révén, } \\
\text { többiek esetén komoly } \\
\text { támogatók megnyerése }\end{array}$ \\
\hline
\end{tabular}




\begin{tabular}{|l|l|l|l|l|} 
& & & & révén \\
\hline $\begin{array}{l}\mathbf{2 8 .} \\
\text { interjúalany }\end{array}$ & stratégia-orientáltság & igen & problémák jelzése révén \\
\hline $\begin{array}{l}\mathbf{2 9 .} \\
\text { interjúalany }\end{array}$ & $\begin{array}{l}\text { projektfolyamat- } \\
\text { centrikus, }\end{array}$ & nem & - & \\
\hline $\begin{array}{l}\mathbf{3 0 .} \\
\text { interjúalany }\end{array}$ & érintett-centrikus & igen & érintettek kezelése \\
\hline $\begin{array}{l}\mathbf{3 1 .} \\
\text { interjúalany }\end{array}$ & érintett-centrikus & igen & változások kezelése \\
\hline
\end{tabular}

Forrás: saját szerkesztés 
A 20. táblázat alapján megállapítható, hogy azon interjúalanyok esetében, akik szerint a projektvezetési szemléletmód hatással van a projektsiker érintettek elégedettségének aspektusára, a válaszok összhangban vannak az alkalmazott projektvezetési szemléletmóddal. A korábbi fejezetek alapján ugyanis a projektfolyamat-centrikusság esetén ismét a tervezésre, a projektteljesítési folyamat megfelelő vezetésére és projekteredmény tesztelésére helyeződne a hangsúly, az érintett-centrikus magatartás esetén a érintettek megfelelö kezelésére, míg a stratégia-orientált megközelítés esetén az üzleti érdek figyelembe vétele alapján alkalmazott érintettek kezelése lehet a kiválasztott eszköz. Ennek fényében csupán a 8., a 9., 14. és a 31. interjúalany jelent kivételt. A 8. projektvezető a hangsúlyt a projektcsapatára helyezi, azonban ha figyelembe vesszük, hogy az agilis projektvezetési eljárás révén a projektcsapat igen fontos érintetté válik, akkor érthető a válasza (föként, ha összevetjük azzal, hogy a felhasználókkal egy multinacionális cég esetén a projektvezető nem mindig áll kapcsolatban). Így az ellentmondás csak látszólagos. A 9. projektvezető a kommunikációt helyezi a középpontba, ami akkor elfogadható, ha a projektfolyamatot és a projekteredményt kommunikálja, így a válasza releváns lehet, még akkor is, ha látszólagos ellentmondás fedezhető fel az általa adott válasz és a projektvezetési szemléletmódja között. A 14. projektvezető stratégia-orientáltsága ellenére a megfelelő motiválásra helyezi a hangsúlyt, amely hasonlóságot mutat a 9. projektvezetővel. Azonban ha figyelembe vesszük a két vállalat közötti eltérést (a 2. vállalat esetén jóval több érintettel kerül kapcsolatban a projektvezető, ld. 10. táblázat), akkor kijelenthető, hogy a motiválás csak korlátozott hatással bír, így nem tekinthető relevánsnak. A 31. projektvezető válasza sem tekinthető relevánsnak, hiszen a változások kezelése (technikai oldalról) inkább projektfolyamat-centrikus projektvezetési szemléletmód sajátja kell, hogy legyen. Mindezekből fakadóan a 14. és 31. projektvezető válasza nem tekinthető relevánsnak az értékelés során.

Amennyiben a projektsiker ezen aspektusára (érintettek elégedettségére) gyakorolt hatás kerül feltérképezésre, óhatatlanul csak a releváns válaszok kerülhetnek figyelembevételre. Így 27 projektvezető válasza tekinthető mérvadónak. Ezek alapján kijelenthető, hogy 24 projektvezető megítélése szerint a projektvezetési szemléletmódnak van hatása a projektsiker érintettek elégedettsége szerinti aspektusára, míg 3 projektvezető szerint nincs. 
Ezek alapján megállapítható tehát, hogy a harmadik hipotézis harmadik része, és ezáltal a harmadik hipotézis elfogadható. Azaz a projektvezetési szemléletmód hatással van a hierarchikus modell szerint értelmezett projektsiker mindhárom szintjére.

A harmadik részben adott válaszokat azonban célszerü lehet egyben is megvizsgálni, nem csak részenként, azaz megbontva sikerkritériumonként. Az összesített válaszokat a 21. táblázat tartalmazza: 
21. táblázat: A projektvezetési szemléletmód hatása a projektháromszög projektsikerre

\begin{tabular}{|c|c|c|c|c|c|}
\hline \multicolumn{2}{|c|}{ Projektsiker } & $\begin{array}{l}\text { Projektvezetői } \\
\text { szemléletmód }\end{array}$ & $\begin{array}{l}\text { Szerinte } \\
\text { hatást } \\
\text { gyakorol-e } \\
\text { az } \\
\text { alkalmazot } \\
\text { t } \\
\text { projektvez } \\
\text { etési } \\
\text { szemléletm } \\
\text { ód a } \\
\text { projekthár } \\
\text { omszög } \\
\text { szerinti } \\
\text { sikeraspekt } \\
\text { usa? }\end{array}$ & $\begin{array}{l}\text { Szerinte } \\
\text { hatást } \\
\text { gyakorol-e } \\
\text { az } \\
\text { alkalmazott } \\
\text { projektvezet } \\
\text { ési } \\
\text { szemléletmó } \\
\text { d a } \\
\text { projekttulaj } \\
\text { donosi } \\
\text { elégedettség } \\
\text { szerinti } \\
\text { sikeraspektu } \\
\text { sa? }\end{array}$ & $\begin{array}{l}\text { Szerinte } \\
\text { hatást } \\
\text { gyakorol-e az } \\
\text { alkalmazott } \\
\text { projektvezeté } \\
\text { i szemléletmó } \\
\text { az érintettek } \\
\text { elégedettsége } \\
\text { szerinti } \\
\text { sikeraspektus } \\
?\end{array}$ \\
\hline \multirow{10}{*}{$\begin{array}{c}1 . \\
\text { vállalat }\end{array}$} & 1. interjúalany & érintett-centrikus & igen & igen & igen \\
\hline & 2. interjúalany & érintett-centrikus & igen & igen & igen (negatívan) \\
\hline & 4. interjúalany & érintett-centrikus & igen & igen & igen \\
\hline & 5. interjúalany & érintett-centrikus & igen & igen & igen \\
\hline & 6. interjúalany & $\begin{array}{l}\text { projektfolyamat- } \\
\text { centrikus }\end{array}$ & igen & igen & igen \\
\hline & 7. interjúalany & $\begin{array}{l}\text { projektfolyamat- } \\
\text { centrikus }\end{array}$ & igen & igen & nem \\
\hline & 8. interjúalany & $\begin{array}{l}\text { stratégia- } \\
\text { orientáltság }\end{array}$ & $\begin{array}{l}\text { igen (segíthet } \\
\text { és gátolhat is) }\end{array}$ & $\begin{array}{l}\text { igen (segíthet és } \\
\text { gátolhat is) }\end{array}$ & igen \\
\hline & 9. interjúalany & $\begin{array}{l}\text { projektfolyamat- } \\
\text { centrikus }\end{array}$ & igen & igen & igen \\
\hline & $\begin{array}{l}10 . \\
\text { interjúalany }\end{array}$ & $\begin{array}{l}\text { projektfolyamat- } \\
\text { centrikus, } \\
\text { érintett-centrikus }\end{array}$ & igen & igen & igen \\
\hline & $\begin{array}{l}11 . \\
\text { interjúalany } \\
\end{array}$ & érintett-centrikus & igen & igen & igen \\
\hline \multirow{2}{*}{$\begin{array}{c}2 . \\
\text { vállalat }\end{array}$} & $\begin{array}{l}12 . \\
\text { interjúalany }\end{array}$ & érintett-centrikus & igen & igen & igen \\
\hline & $\begin{array}{l}13 . \\
\text { interjúalany }\end{array}$ & érintett-centrikus & igen & részben & igen \\
\hline
\end{tabular}




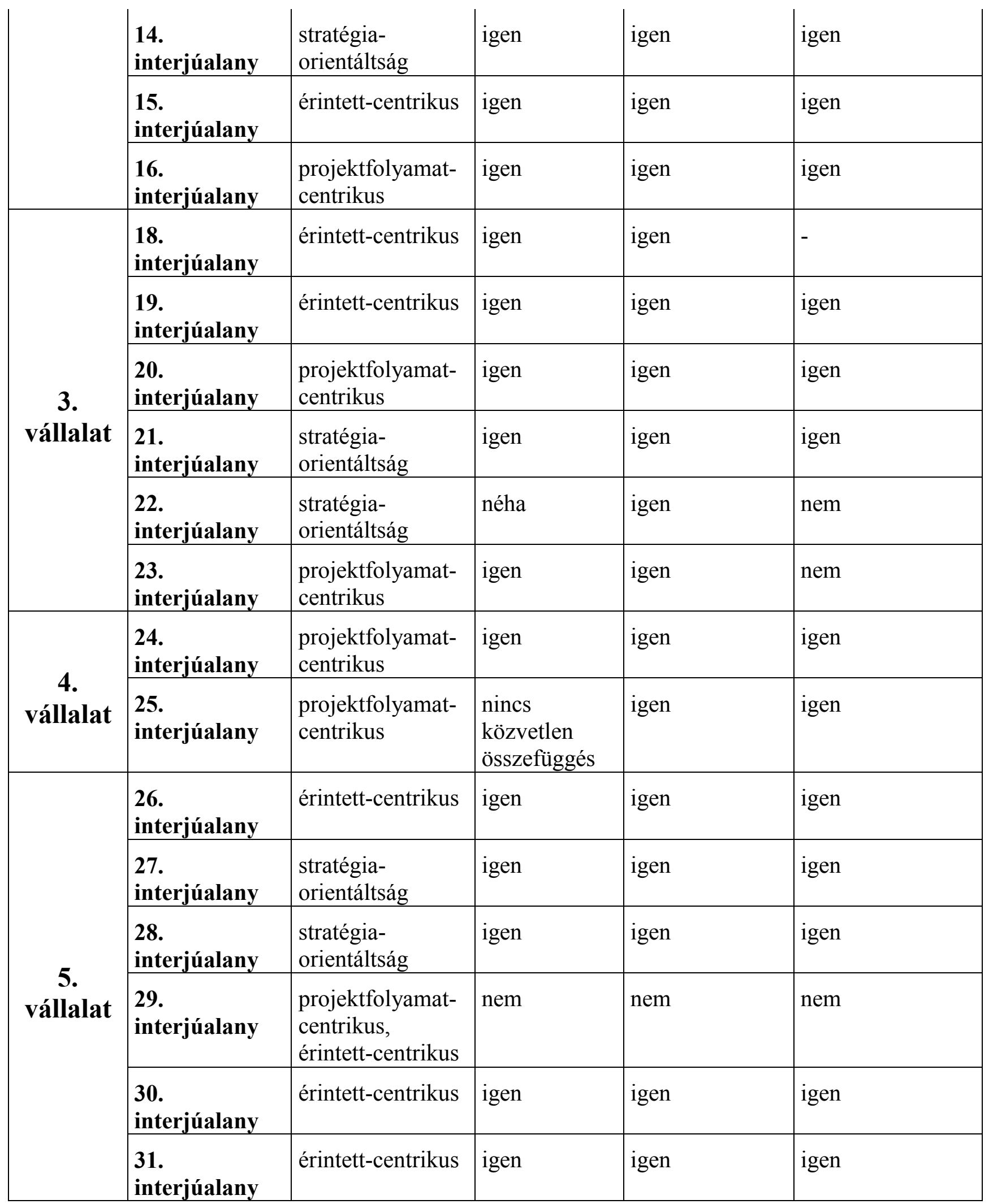

Forrás: saját szerkesztés

A korábbiakban leírtak értelmében kizárásra kell, hogy kerüljön az a projektvezető, amely nem adott a szemléletmódjával konzisztens választ. A projektháromszög szerinti sikerértelmezés esetén az 5., 15., 20. és 31. interjúalany 
volt ilyen, a projekttulajdonosi szervezet elégedettsége szerinti sikerértelmezés esetén a 9., 13. és 31. interjúalany volt ilyen, míg az érintettek elégedettsége szerinti sikerértelmezés esetén a 14. és 31. projektvezető volt ilyen. Célszerü lehet a szigorú kritérium alkalmazása jelen esetben, azaz kizárni azt a projektvezetőt a válasz alapjául szolgáló mintából, aki egyszer inkonzisztens választ adott. Ennek fényében nem került figyelembe vételre az 5., 9., 13., 14., 15., 20. és 31. projektvezető.

Ha megvizsgáljuk a csökkentett mintát, akkor látható, hogy 17 projektvezető szerint a siker mindhárom aspektusára (projektháromszög, projekttulajdonosi elégedettség és érintettek elégedettsége szerint értelmezett projektsikerre) hatással van az általa alkalmazott projektvezetési szemléletmód. Egy olyan projektvezető volt, aki szerint kettő sikerkritérium szerint értelmezett projektsikerre gyakorol hatást, egyre pedig részben (a 13.). Két olyan projektvezető volt, aki szerint kettőre gyakorol hatást, egyre nem (a 23. és 25.). Egy olyan, aki szerint néha gyakorol hatást az egyik projektsiker szintre, egyre pedig nem (a 22.). Végül egy olyan projektvezető van (a 29.), aki szerint a projektvezetési szemléletmód nem gyakorol hatást a projektsiker egyik aspektusára sem. Ezek alapján meg lehet állapítani, hogy 17 olyan projektvezető volt, aki szerint hatást gyakorol a projektvezetési szemléletmód a projektsiker mindhárom szintjére, míg 5 olyan, aki szerint nem. Ez tovább erősíti a harmadik hipotézis elfogadásának jogosságát ${ }^{49}$.

Ha tágabban nézzük, akkor csupán egy olyan projektvezető volt (a 29.), aki szerint a projektsiker egyik aspektusára sem gyakorol hatást a projektvezetési szemléletmód, és 21 olyan, aki szerint gyakorol legalább az egyik aspektusára hatást.

Összességében tehát ki lehet jelenteni, hogy a harmadik hipotézis elfogadása indokolt.

Érdemes megemlíteni, hogyha a projektvezető projektvezetési szemléletmódja kialakul a projektvezetőben, a második hipotézis értelmében a tacit tudás legalább olyan fontossággal bír esetében, mint az explicit. Azonban a projektvezetőnek bizonyos mértékű ráhatása lehet arra, hogy milyen projektvezetési szemléletmódot követ, azaz feltételezhetjük, hogy a lehető legjobbat követi, amely szerinte a sikerre a legnagyobb hatást gyakorolja. Talán az egyik projektvezető mondata foglalja össze

\footnotetext{
49 Különösen akkor, ha figyelembe vesszük azt a tényt, hogy a kizárt projektvezetők mindegyike szerint a szemléletmód a projektsiker mindhárom szintjére hatást gyakorol.
} 
leginkább, amely a következőképpen szólt: „Ha nem gondolnám, hogy a szemléletmódon hatást gyakorol a sikerre, nem ezt követném!"

\subsubsection{A személyiségjegyek vezetési stílusra és projektvezetési szemléletmódra gyakorolt hatásának értékelése}

A kutatás utolsó részében a projektvezető személyiségjegyeinek hatása került feltérképezésre a projektvezetési szemléletmód és a vezetési stílus tükrében. Ahogy korábban ismertetésre került, ez a projektvezetési szemléletmód esetén kettő, a vezetési stílus esetén három lépésben került kivitelezésre. A személyiségjegy alatt a korábban ismertetett hat (optimizmus, érzelmi intelligencia, csapatépítő képesség, bizalomépítő képesség, motiváló képesség és improvizáció) képezte az alapot a kutatáshoz. Azonban meg kell említeni, hogy a csapatépítő képesség esetén csupán 9 válasz érkezett, ezért ennek relevanciája megkérdezhető, de a teljesség igénye miatt szerepel a kutatásban.

A kutatás során a projektvezető személyiségjegyeinek hatása egyszerre került feltérképezésre, a könnyebb érthetőség kedvéért külön-külön kerülnek bemutatásra.

\subsubsection{A személyiségjegyek hatása a projektvezetési szemléletmódra}

A kutatás negyedik részének első lépése során a projektvezetőknek meg kellett említenie azokat a faktorokat, amik hatottak a projektvezetési szemléletmódjaikra. A projektvezetőnek először saját magától kellett azonosítania a faktorokat, azonban ha nem tudott, akkor segítséget kapott. Meg lett említve, hogy a neveltetése, oktatása, személyiségjegyei, a vállalati kultúra vagy bizonyos esetekben a korábbi főnökök hatottak-e rá. Ha a személyiségjegyeit nem említette, akkor szintén fel lett téve a kérdés, hogy a korábban említett öt faktor (természetesen figyelembe véve a korábbi válaszait) hatott-e rá. Ezek alapján a következő válaszok születtek: 
22. táblázat: A projektvezetési szemléletmódra hatást gyakoroló faktorok

\begin{tabular}{|c|c|c|}
\hline & $\begin{array}{l}\text { Faktorok, } \\
\text { amelyek hatást } \\
\text { gyakoroltak a } \\
\text { projektvezetési } \\
\text { szemléletmódra }\end{array}$ \\
\hline \multirow{10}{*}{$\begin{array}{c}1 . \\
\text { vállalat }\end{array}$} & 1. interjúalany & $\begin{array}{l}\text { tapasztalat, } \\
\text { oktatás, } \\
\text { neveltetés, } \\
\text { korábbi fönökök, } \\
\text { vállalati kultúra, } \\
\text { személyiségjegyek }\end{array}$ \\
\hline & 2. interjúalany & $\begin{array}{l}\text { tapasztalat, } \\
\text { személyiségjegyek }\end{array}$ \\
\hline & 4. interjúalany & $\begin{array}{l}\text { megrendelö, } \\
\text { személyiségjegyek }\end{array}$ \\
\hline & 5. interjúalany & $\begin{array}{l}\text { tapasztalat, } \\
\text { oktatás, } \\
\text { neveltetés, } \\
\text { korábbi fönökök, } \\
\text { ügyfél, } \\
\text { személyiségjegyek }\end{array}$ \\
\hline & 6. interjúalany & $\begin{array}{l}\text { tapasztalat, } \\
\text { vállalati kultúra, } \\
\text { személyiségjegyek }\end{array}$ \\
\hline & 7. interjúalany & $\begin{array}{l}\text { tapasztalat, } \\
\text { oktatás, } \\
\text { vállalati kultúra, } \\
\text { személyiségjegyek }\end{array}$ \\
\hline & 8. interjúalany & $\begin{array}{l}\text { oktatás, } \\
\text { vállalati kultúra, } \\
\text { személyiségjegyek }\end{array}$ \\
\hline & 9. interjúalany & $\begin{array}{l}\text { oktatás, } \\
\text { neveltetés, } \\
\text { vállalati kultúra, } \\
\text { személyiségjegyek }\end{array}$ \\
\hline & $\begin{array}{l}10 . \\
\text { interjúalany }\end{array}$ & $\begin{array}{l}\text { oktatás, } \\
\text { neveltetés, } \\
\text { vállalati kultúra, } \\
\text { személyiségjegyek }\end{array}$ \\
\hline & $\begin{array}{l}11 . \\
\text { interjúalany }\end{array}$ & $\begin{array}{l}\text { oktatás, } \\
\text { neveltetés, } \\
\text { vállalati kultúra, } \\
\text { személyiségjegyek }\end{array}$ \\
\hline
\end{tabular}




\begin{tabular}{|c|c|c|}
\hline & Összesen & $\begin{array}{l}\text { tapasztalat (5), } \\
\text { oktatás (7), } \\
\text { neveltetés (5), } \\
\text { korábbi fönökök (2), } \\
\text { vállalati kultúra (7), } \\
\text { személyiségjegyek } \\
(10), \\
\text { ügyfél (2) }\end{array}$ \\
\hline \multirow{6}{*}{$\begin{array}{c}2 . \\
\text { vállalat }\end{array}$} & $\begin{array}{l}12 . \\
\text { interjúalany }\end{array}$ & $\begin{array}{l}\text { oktatás, } \\
\text { vállalati kultúra, } \\
\text { személyiségjegyek }\end{array}$ \\
\hline & $\begin{array}{l}13 . \\
\text { interjúalany }\end{array}$ & $\begin{array}{l}\text { tapasztalat, } \\
\text { neveltetés, } \\
\text { vállalati kultúra, } \\
\text { személyiségjegyek }\end{array}$ \\
\hline & $\begin{array}{l}14 . \\
\text { interjúalany }\end{array}$ & $\begin{array}{l}\text { korábbi főnökök, } \\
\text { kollégák, } \\
\text { személyiségjegyek }\end{array}$ \\
\hline & $\begin{array}{l}15 . \\
\text { interjúalany }\end{array}$ & $\begin{array}{l}\text { tapasztalat, } \\
\text { oktatás, } \\
\text { vállalati kultúra, } \\
\text { személyiségjegyek }\end{array}$ \\
\hline & $\begin{array}{l}16 . \\
\text { interjúalany }\end{array}$ & $\begin{array}{l}\text { tapasztalat, } \\
\text { oktatás, } \\
\text { vállalati kultúra, } \\
\text { személyiségjegyek }\end{array}$ \\
\hline & Összesen & $\begin{array}{l}\text { tapasztalat (3), } \\
\text { oktatás (3), } \\
\text { neveltetés (1), } \\
\text { korábbi fönökök (1), } \\
\text { vállalati kultúra (4), } \\
\text { személyiségjegyek (5), } \\
\text { kollégák (1) }\end{array}$ \\
\hline \multirow{2}{*}{$\begin{array}{c}3 . \\
\text { vállalat }\end{array}$} & $\begin{array}{l}18 . \\
\text { interjúalany }\end{array}$ & $\begin{array}{l}\text { oktatás, } \\
\text { neveltetés, } \\
\text { korábbi főnökök, } \\
\text { vállalati kultúra, } \\
\text { személyiségjegyek }\end{array}$ \\
\hline & $\begin{array}{l}19 . \\
\text { interjúalany }\end{array}$ & $\begin{array}{l}\text { tapasztalat, } \\
\text { oktatás, } \\
\text { neveltetés, } \\
\text { korábbi fönökök, } \\
\text { vállalati kultúra, } \\
\text { személyiségjegyek }\end{array}$ \\
\hline
\end{tabular}




\begin{tabular}{|c|c|c|}
\hline & $\begin{array}{l}20 . \\
\text { interjúalany }\end{array}$ & $\begin{array}{l}\text { tapasztalat, } \\
\text { oktatás, } \\
\text { vállalati kultúra, } \\
\text { személyiségjegyek }\end{array}$ \\
\hline & $\begin{array}{l}21 . \\
\text { interjúalany }\end{array}$ & $\begin{array}{l}\text { tapasztalat, } \\
\text { korábbi fönökök, } \\
\text { vállalati kultúra, } \\
\text { személyiségjegyek }\end{array}$ \\
\hline & $\begin{array}{l}22 . \\
\text { interjúalany }\end{array}$ & $\begin{array}{l}\text { korábbi fönökök, } \\
\text { vállalati kultúra, } \\
\text { személyiségjegyek }\end{array}$ \\
\hline & $\begin{array}{l}23 . \\
\text { interjúalany }\end{array}$ & $\begin{array}{l}\text { oktatás, } \\
\text { neveltetés, } \\
\text { személyiségjegyek }\end{array}$ \\
\hline & Összesen & $\begin{array}{l}\text { tapasztalat (3), } \\
\text { oktatás (4), } \\
\text { neveltetés (3), } \\
\text { korábbi fönökök (4), } \\
\text { vállalati kultúra (5), } \\
\text { személyiségjegyek (6) }\end{array}$ \\
\hline \multirow{3}{*}{$\begin{array}{c}4 . \\
\text { vállalat }\end{array}$} & $\begin{array}{l}24 . \\
\text { interjúalany }\end{array}$ & $\begin{array}{l}\text { neveltetés, } \\
\text { vállalati kultúra, } \\
\text { személyiségjegyek }\end{array}$ \\
\hline & $\begin{array}{l}25 . \\
\text { interjúalany }\end{array}$ & $\begin{array}{l}\text { neveltetés, } \\
\text { vállalati kultúra, } \\
\text { személyiségjegyek }\end{array}$ \\
\hline & Összesen & $\begin{array}{l}\text { neveltetés (2), } \\
\text { vállalati kultúra (2), } \\
\text { személyiségjegyek (2) }\end{array}$ \\
\hline \multirow{5}{*}{$\begin{array}{c}5 . \\
\text { vállalat }\end{array}$} & $\begin{array}{l}26 . \\
\text { interjúalany }\end{array}$ & $\begin{array}{l}\text { neveltetés, } \\
\text { vállalati kultúra, } \\
\text { személyiségjegyek }\end{array}$ \\
\hline & $\begin{array}{l}27 . \\
\text { interjúalany }\end{array}$ & \begin{tabular}{|l} 
vállalati kultúra, \\
személyiségjegyek
\end{tabular} \\
\hline & $\begin{array}{l}28 . \\
\text { interjúalany }\end{array}$ & $\begin{array}{l}\text { tapasztalat, } \\
\text { korábbi fönökök, } \\
\text { vállalati kultúra, } \\
\text { személyiségjegyek }\end{array}$ \\
\hline & $\begin{array}{l}29 . \\
\text { interjúalany }\end{array}$ & $\begin{array}{l}\text { korábbi fónökök, } \\
\text { vállalati kultúra, } \\
\text { személyiségjegyek }\end{array}$ \\
\hline & $\begin{array}{l}30 . \\
\text { interjúalany }\end{array}$ & $\begin{array}{l}\text { korábbi fónökök, } \\
\text { vállalati kultúra, } \\
\text { személyiségjegyek }\end{array}$ \\
\hline
\end{tabular}




\begin{tabular}{|c|c|c|}
\hline & $\begin{array}{l}31 . \\
\text { interjúalany }\end{array}$ & $\begin{array}{l}\text { tapasztalat, } \\
\text { oktatás, } \\
\text { vállalati kultúra, } \\
\text { személyiségjegyek }\end{array}$ \\
\hline & Összesen & $\begin{array}{l}\text { tapasztalat (2), } \\
\text { oktatás (1), } \\
\text { neveltetés (1), } \\
\text { korábbi fönökök (3), } \\
\text { vállalati kultúra (6), } \\
\text { személyiségjegyek (6) }\end{array}$ \\
\hline Összesen & & $\begin{array}{l}\text { tapasztalat (12), } \\
\text { oktatás (15), } \\
\text { neveltetés (12), } \\
\text { korábbi fönökök (10), } \\
\text { vállalati kultúra (24), } \\
\text { személyiségjegyek } \\
(29), \\
\text { kollégák (1), } \\
\text { ügyfél (2) }\end{array}$ \\
\hline
\end{tabular}

Forrás: saját szerkesztés

A 22. táblázat alapján megállapítható, hogy a személyiségjegyek mindenképpen hatást gyakoroltak a projektvezető projektvezetési szemléletmódra, hiszen azokat minden projektvezető említette. Természetesen ez nem azt jelenti, hogy a személyiségjegyei gyakorolták a legmarkánsabb hatást minden esetben a projektvezető projektvezetési szemléletmódjára, hiszen pl. a 16-os és 25-ös interjúalany kiemelte, hogy számára a legmarkánsabb tényező a vállalati kultúra volt. Azonban a kutatásnak nem volt célja, hogy a hatás mértékét feltárja, vagy azonosítsa, hogy melyik tényező fejtette ki a legmarkánsabb hatást. A személyiségjegyek és a vállalati kultúra mellett fontos még megemlíteni az oktatást, hiszen a projektvezetők több, mint fele említette. Érdekes megközelítést jelent, ha nem makroszinten kerülnek az adatok vizsgálatra, hanem mikroszinten, azaz megnézni, a vállalatokat egyenként. Itt már jelentős eltérés tapasztalható, hiszen pl. az oktatás az első vállalat esetén igen fontos, a második, harmadik esetén szintén fontos, de kevésbé, míg a negyedik és ötödik cég esetén csak kevésbé. A korábbi vezetőknél szintén jelentés eltérést tapasztalhatunk, hiszen míg a 3. és 5. vállalat esetén fontos szerephez jutnak, addig a többi esetén nem annyira. A tapasztalat pedig mindenhol közepes fontossággal bír (kivéve a 4. vállalat esetén). Külön érdekesség, hogy a 4. vállalat esetén mindkét projektvezető ugyanazokat a tényezőket említette természetesen egymástól függetlenül. Meg kell említeni még továbbá, hogy a 
korábbi vezetők igen gyakran kerültek említésre anélkül, hogy az öt faktor ismertetésre került volna, körülbelül megegyező gyakorisággal, mint a személyiségjegy vagy a vállalati kultúra. Mindezek alapján két dolgot meg lehet állapítani. Az első, hogy a személyiségjegyek és a vállalati kultúra a legtöbb projektvezető (az előbbi az összes, az utóbbi a projektvezetők több mint 80\%-ának esetén) projektvezetési szemléletmódjára hatást gyakorol. A második, hogy a részletesebb vizsgálat indokolt, hiszen a projektvezetők vállalati bontásban - annak ellenére, hogy a cégek látszólag hasonló jellemzőkkel bírnak és ugyanabban az iparágban dolgoznak - a többi tényező esetén eléggé megosztottak. Ez azt sejteti, hogy a projektvezetési kultúrában és a projektvezetők kiválasztásában/kinevelésében jelentős eltérések tapasztalhatóak a vállalatok között.

Mindezek fényében leszögezhető, hogy jelentős esély mutatkozik a negyedik hipotézis első részének elfogadására.

Azonban a projektvezető személyiségjegyeinek hatását szükséges a változással is vizsgálni. Azaz a projektvezetőknek arra a kérdésre is válaszolniuk kellett, hogy szerinte amennyiben változna a személyiségjegye (vagy személyiségjegyei), akkor az magával vonzaná a projektvezetési szemléletmódjának változását. Ezek alapján a következő válaszok születtek:

23. táblázat: A személyiségjegyek változásának hatása

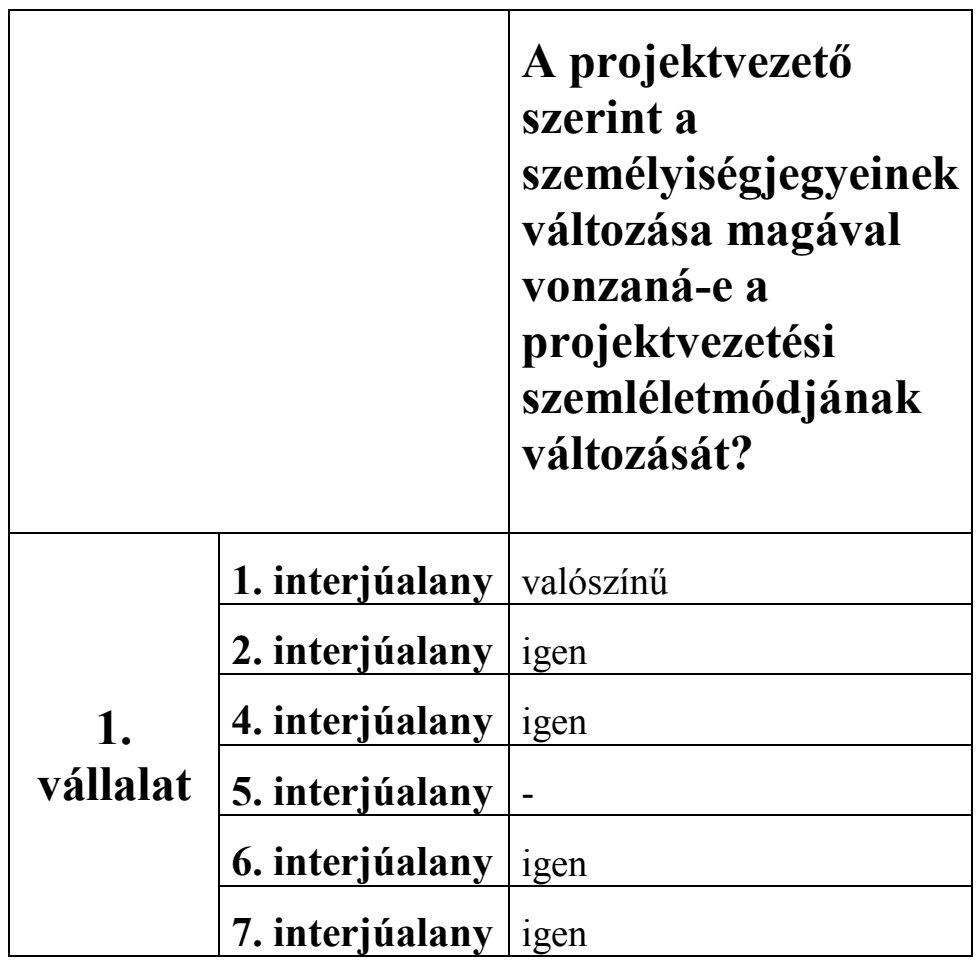




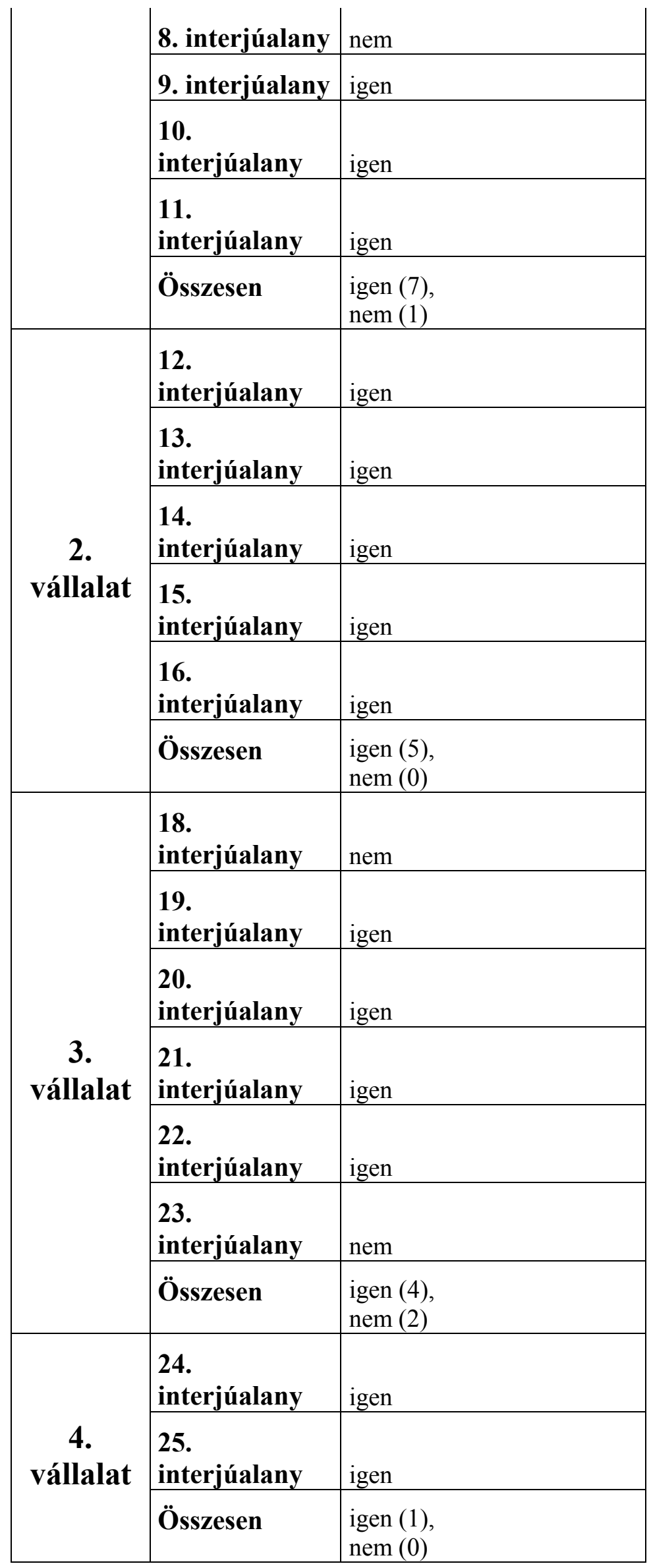




\begin{tabular}{|c|c|c|}
\hline \multirow{7}{*}{$\begin{array}{c}5 . \\
\text { vállalat }\end{array}$} & $\begin{array}{l}26 . \\
\text { interjúalany }\end{array}$ & igen \\
\hline & $\begin{array}{l}27 . \\
\text { interjúalany }\end{array}$ & igen \\
\hline & $\begin{array}{l}28 . \\
\text { interjúalany }\end{array}$ & igen \\
\hline & $\begin{array}{l}29 . \\
\text { interjúalany }\end{array}$ & nem \\
\hline & $\begin{array}{l}30 . \\
\text { interjúalany }\end{array}$ & igen \\
\hline & $\begin{array}{l}31 . \\
\text { interjúalany }\end{array}$ & igen \\
\hline & Összesen & $\begin{array}{l}\text { igen (5), } \\
\text { nem (1) }\end{array}$ \\
\hline \multicolumn{2}{|l|}{ Összesen } & $\begin{array}{l}\text { igen (22), } \\
\text { nem (4) }\end{array}$ \\
\hline
\end{tabular}

Forrás: saját szerkesztés

A 23. táblázat alapján leszürhető, hogy 22 projektvezető úgy gondolja, hogy amennyiben változna a személyiségjegye, akkor változna a projektvezetési szemléletmódja is. Egy nem adott választ, egy szerint valószínű (azaz bizonytalan, válaszát nem lehet figyelembe venni), míg 4 gondolja úgy, hogy nem. Utóbbi kategóriába tartozók azzal indokolták a válaszukat, hogy a személyiségjegyek megcsontosodtak, azok nem változnak, így a kérdés irreleváns ${ }^{50}$. Kiemelendő a negyedik vállalat, ahol a projektvezetők harmada gondolta úgy, hogy nem változik a projektvezető projektvezetői szemléletmódja a személyiségjegyek változásának hatására. Természetesen ez némileg ellentmond a korábbi eredménynek, hiszen mindegyik projektvezető úgy vélte, hogy a személyiségjegyek hatással vannak a projektvezetési szemléletmódra, míg jelen esetben négyen vélték azt, hogy hiába változna a személyiségjegye, nem változna a projektvezetési szemléletmódja. Azonban az ellentmondás csak látszólagos, hiszen nem a személyiségjegy hatását zárja ki, hanem annak változását nem tudta elfogadni. Így megállapítható, hogy a

50 A válaszukat az is indokolhatta, hogy vannak az embernek bizonyos veleszületett személyiségjegyei, amelyek nehezen vagy nem változtathatóak. A pszichológiában gyakran találkozunk ezzel (vö. Cloninger, 1994). A projektvezetők valószínüsíthetően ennek alapján ítélték meg a hat személyiségjegyet is, bár ketten hozzátették, hogy finomodhat, de nem változhat. Annak megítélésére, hogy helyesen vagy helytelenül ítélték meg, további vizsgálatok lennének szükségesek, hiszen igazságtartalmuk -a szakirodalom ellenére (vö. Müller - Turner, 2007; 2010) nem vethető el. Azonban ez nem képezi a dolgozat tartalmát. 
személyiségjegyek hatással vannak a projektvezetési szemléletmódra, 22 úgy véli, hogy a személyiségjegyeinek változása magával vonzaná a másik projektvezetői szemléletmód változását, míg 4 úgy véli, hogy már nem változik abban a korban az ember, viszont a projektvezetési szemléletmód kialakulásában fontos szerepet játszik a személyiségjegy. 3 projektvezető pedig nem tudott válaszolni erre a kérdésre .

Mindezek alapján kijelenthető, hogy a negyedik hipotézis első fele elfogadható, azaz a projektvezető személyiségjegyeinek hatása van a projektvezetési szemléletmódra. Azonban két körülményre fel kell mindenképpen hívni ismételten a figyelmet. A kutatás nem állítja, nem is állíthatja az eredmények tükrében, hogy csak és kizárólag a személyiségjegy gyakorol hatást a projektvezetési szemléletmódra. Illetve a kutatásnak nem volt célja a hatás mértékének azonosítása, mint ahogy az sem, hogy azonosítja azt a faktort, amelyik a legnagyobb hatást gyakorolja a projektvezetési szemléletmódra.

\subsubsection{A személyiségjegyek hatása a vezetési stílusra}

A kutatás negyedik részének a második felét a személyiségjegyek vezetési stílusra gyakorolt hatásának feltérképezése jelentette. A kutatás ezen része három fázisból épült fel. Az első fázisban - hasonlóan a projektvezetési szemléletmódra gyakoroltak hatás esetén - a projektvezetőnek saját szavaival el kellett mondania, hogy szerinte milyen tényezők gyakoroltat hatást. Amennyiben nem tudott mondani (vagy a személyiségjegy nem hangzott el), a korábban említett öt tényező (személyiségjegy, vállalati kultúra, neveltetés, oktatás és bizonyos esetekben a korábbi vezetők) említésre került. Ezek alapján a projektvezetők a következő válaszokat adták:

24. táblázat: A vezetési stílusra hatást gyakoroló faktorok

\begin{tabular}{|c|c|l|}
\hline \multicolumn{2}{|l|}{} & $\begin{array}{l}\text { Faktorok, } \\
\text { amelyek hatást } \\
\text { gyakoroltak a } \\
\text { vezetési stílusra }\end{array}$ \\
\hline $\begin{array}{l}\text { 1. } \\
\text { vállalat }\end{array}$ & 1. interjúalany & $\begin{array}{l}\text { tapasztalat (életbeli is), } \\
\text { oktatás, } \\
\text { neveltetés, } \\
\text { korábbi vezetők, } \\
\text { vállalati kultúra, } \\
\text { személyiségjegyek, }\end{array}$ \\
\hline
\end{tabular}




\begin{tabular}{|c|c|}
\hline 2. interjúalany & $\begin{array}{l}\text { tapasztalat, } \\
\text { személyiségjegyek, } \\
\text { korábbi fönök }\end{array}$ \\
\hline 4. interjúalany & $\begin{array}{l}\text { megrendelö, } \\
\text { személyiségjegyek, }\end{array}$ \\
\hline 5. interjúalany & $\begin{array}{l}\text { tapasztalat, } \\
\text { oktatás, } \\
\text { neveltetés, } \\
\text { korábbi vezetők, } \\
\text { ügyfél, } \\
\text { személyiségjegyek }\end{array}$ \\
\hline 6. interjúalany & $\begin{array}{l}\text { tapasztalat, } \\
\text { oktatás, } \\
\text { vállalati kultúra, } \\
\text { személyiségjegyek }\end{array}$ \\
\hline 7. interjúalany & $\begin{array}{l}\text { tapasztalat, } \\
\text { oktatás, } \\
\text { vállalati kultúra, } \\
\text { személyiségjegyek }\end{array}$ \\
\hline 8. interjúalany & $\begin{array}{l}\text { oktatás, } \\
\text { vállalati kultúra, } \\
\text { személyiségjegyek }\end{array}$ \\
\hline 9. interjúalany & $\begin{array}{l}\text { oktatás, } \\
\text { neveltetés, } \\
\text { vállalati kultúra, } \\
\text { személyiségjegyek, } \\
\text { korábbi vezetők } \\
\end{array}$ \\
\hline $\begin{array}{l}10 . \\
\text { interjúalany }\end{array}$ & $\begin{array}{l}\text { neveltetés, } \\
\text { vállalati kultúra, } \\
\text { korábbi vezetők } \\
\text { személyiségjegyek }\end{array}$ \\
\hline $\begin{array}{l}11 . \\
\text { interjúalany }\end{array}$ & $\begin{array}{l}\text { oktatás, } \\
\text { neveltetés, } \\
\text { korábbi vezetők } \\
\text { vállalati kultúra, } \\
\text { személyiségjegyek }\end{array}$ \\
\hline Összesen & $\begin{array}{l}\text { tapasztalat (5), } \\
\text { oktatás (7), } \\
\text { neveltetés (5), } \\
\text { korábbi vezetők (6), } \\
\text { vállalati kultúra (7), } \\
\text { személyiségjegyek } \\
(10), \\
\text { ügyfél (2) }\end{array}$ \\
\hline
\end{tabular}




\begin{tabular}{|c|c|c|}
\hline \multirow{6}{*}{$\begin{array}{c}2 . \\
\text { vállalat }\end{array}$} & $\begin{array}{l}12 . \\
\text { interjúalany }\end{array}$ & $\begin{array}{l}\text { oktatás, } \\
\text { vállalati kultúra, } \\
\text { személyiségjegyek }\end{array}$ \\
\hline & $\begin{array}{l}13 . \\
\text { interjúalany }\end{array}$ & $\begin{array}{l}\text { tapasztalat, } \\
\text { neveltetés, } \\
\text { vállalati kultúra, } \\
\text { személyiségjegyek } \\
\end{array}$ \\
\hline & $\begin{array}{l}14 . \\
\text { interjúalany }\end{array}$ & $\begin{array}{l}\text { korábbi vezetők, } \\
\text { kollégák, } \\
\text { személyiségjegyek }\end{array}$ \\
\hline & $\begin{array}{l}15 . \\
\text { interjúalany }\end{array}$ & \begin{tabular}{|l} 
tapasztalat, \\
oktatás, \\
vállalati kultúra, \\
korábbi fönök, \\
személyiségjegyek \\
\end{tabular} \\
\hline & $\begin{array}{l}16 . \\
\text { interjúalany }\end{array}$ & $\begin{array}{l}\text { tapasztalat, } \\
\text { oktatás, } \\
\text { vállalati kultúra, } \\
\text { személyiségjegyek }\end{array}$ \\
\hline & Összesen & $\begin{array}{l}\text { tapasztalat (3), } \\
\text { oktatás (3), } \\
\text { neveltetés (2), } \\
\text { korábbi vezetők (1), } \\
\text { vállalati kultúra (4), } \\
\text { személyiségjegyek (5), } \\
\text { kollégák (1) }\end{array}$ \\
\hline \multirow{5}{*}{$\begin{array}{c}3 . \\
\text { vállalat }\end{array}$} & $\begin{array}{l}18 . \\
\text { interjúalany }\end{array}$ & $\begin{array}{l}\text { vállalati környezet } \\
\text { (kultúra) }\end{array}$ \\
\hline & $\begin{array}{l}19 . \\
\text { interjúalany }\end{array}$ & $\begin{array}{l}\text { tapasztalat, } \\
\text { oktatás, } \\
\text { neveltetés, } \\
\text { korábbi vezetők, } \\
\text { vállalati kultúra, } \\
\text { személyiségjegyek }\end{array}$ \\
\hline & $\begin{array}{l}20 . \\
\text { interjúalany }\end{array}$ & $\begin{array}{l}\text { tapasztalat, } \\
\text { oktatás, } \\
\text { vállalati kultúra, } \\
\text { személyiségjegyek }\end{array}$ \\
\hline & $\begin{array}{l}21 . \\
\text { interjúalany }\end{array}$ & $\begin{array}{l}\text { tapasztalat, } \\
\text { korábbi vezetők, } \\
\text { vállalati kultúra, } \\
\text { személyiségjegyek }\end{array}$ \\
\hline & $\begin{array}{l}22 . \\
\text { interjúalany }\end{array}$ & $\begin{array}{l}\text { korábbi vezetők, } \\
\text { vállalati kultúra, } \\
\text { személyiségjegyek }\end{array}$ \\
\hline
\end{tabular}




\begin{tabular}{|c|c|c|}
\hline & $\begin{array}{l}23 . \\
\text { interjúalany }\end{array}$ & $\begin{array}{l}\text { oktatás, } \\
\text { neveltetés, } \\
\text { személyiségjegyek }\end{array}$ \\
\hline & Összesen & $\begin{array}{l}\text { tapasztalat (3), } \\
\text { oktatás (3), } \\
\text { neveltetés (2), } \\
\text { korábbi vezetők (3), } \\
\text { vállalati kultúra (5), } \\
\text { személyiségjegyek (5) }\end{array}$ \\
\hline \multirow{3}{*}{$\begin{array}{c}4 . \\
\text { vállalat }\end{array}$} & $\begin{array}{l}24 . \\
\text { interjúalany }\end{array}$ & $\begin{array}{l}\text { korábbi fönök, } \\
\text { vállalati kultúra, } \\
\text { személyiségjegyek }\end{array}$ \\
\hline & $\begin{array}{l}25 . \\
\text { interjúalany }\end{array}$ & $\begin{array}{l}\text { tapasztalat, } \\
\text { vállalati kultúra, } \\
\text { személyiségjegyek }\end{array}$ \\
\hline & Összesen & $\begin{array}{l}\text { neveltetés (1), } \\
\text { tapasztalat (1), } \\
\text { korábbi fönök (1), } \\
\text { vállalati kultúra (2), } \\
\text { személyiségjegyek (2) }\end{array}$ \\
\hline \multirow{7}{*}{$\begin{array}{c}5 . \\
\text { vállalat }\end{array}$} & \begin{tabular}{|l}
26. \\
interjúalany
\end{tabular} & $\begin{array}{l}\text { vállalati kultúra, } \\
\text { tapasztalat }\end{array}$ \\
\hline & $\begin{array}{l}27 . \\
\text { interjúalany }\end{array}$ & vállalati kultúra, \\
\hline & $\begin{array}{l}28 . \\
\text { interjúalany }\end{array}$ & korábbi vezetők, \\
\hline & $\begin{array}{l}29 . \\
\text { interjúalany }\end{array}$ & $\begin{array}{l}\text { tapasztalat, } \\
\text { személyiségjegyek }\end{array}$ \\
\hline & $\begin{array}{l}30 . \\
\text { interjúalany }\end{array}$ & $\begin{array}{l}\text { korábbi vezetők, } \\
\text { vállalati kultúra, } \\
\text { személyiségjegyek }\end{array}$ \\
\hline & $\begin{array}{l}31 . \\
\text { interjúalany }\end{array}$ & $\begin{array}{l}\text { tapasztalat, } \\
\text { oktatás, } \\
\text { vállalati kultúra, } \\
\text { személyiségjegyek }\end{array}$ \\
\hline & Összesen & $\begin{array}{l}\text { tapasztalat (3), } \\
\text { oktatás (1), } \\
\text { neveltetés }(0), \\
\text { korábbi vezetők (2), } \\
\text { vállalati kultúra (4), } \\
\text { személyiségjegyek (3) }\end{array}$ \\
\hline
\end{tabular}




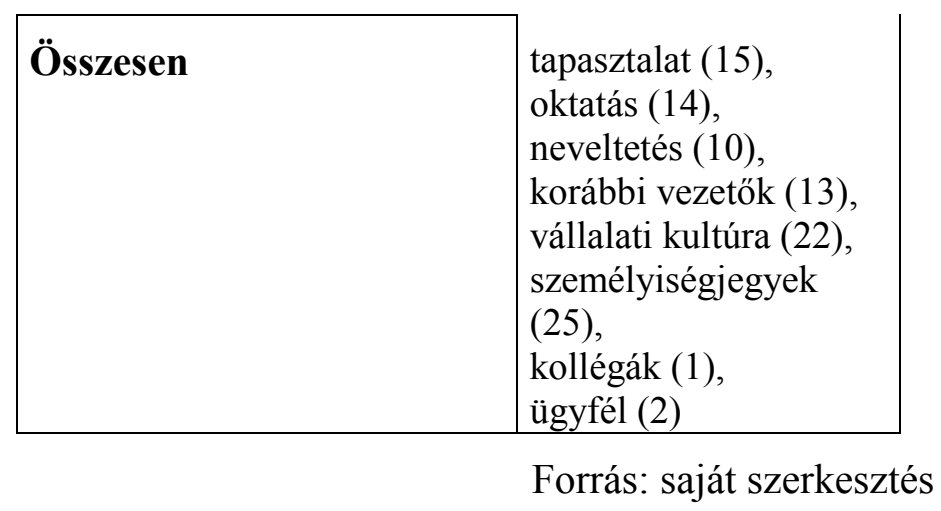

A 24. táblázat alapján megállapítható, hogy a projektvezetők többsége ugyanazokat a válaszokat adtál, kivételt képez a 2., a 6., a 9., a 10., a 15., a 24., a 25. , a 26., a 27., a 28. és a 29. interjúalany, azaz 11-en érezték úgy, hogy más faktor hat a vezetési stílusára. Ez a projektvezetők közel 40\%-a, amely jelentősnek tekinthető. Legjelentősebb eltérés a tapasztalat és a korábbi vezetők növekedésében van (3). Külön kiemelendő, hogy 4 projektvezető találta úgy, hogy a korábbi vezető hatott a vezetési stílusára és a projektvezetési szemléletmódjára nem, egy pedig fordítva. A legjelentősebb csökkenés a személyiségjegyek számában (4) van, de csökkent az oktatás (1), a neveltetés (2) és a vállalati kultúra (2) is. Továbbá megállapítható, hogy a 4. vállalat már nem olyan egységes a hatással lévő faktorok terén, mint a projektvezetési szemléletmód esetén. De megállapítható, hogy új faktor nem került hozzáadásra. Összességében megállapítható, hogy a vezetési stílus kialakulásában a környezetnek (tapasztalat, korábbi fönök, vállalati kultúra) nagyobb hatása van, mint a projektvezetési szemléletmód esetén, még akkor is, ha a vállalati kultúrát kevesebb a projektvezető említette mint hatást gyakorló faktort. A hozott értékeknek (oktatás, neveltetés, személyiségjegyek) kevesebben tulajdonítanak fontos szerepet. Ez azt sejteti, hogy tacit tudásátadás a vezetési stílus esetén fontosabbá válhat, mint a projektvezetési szemléletmód esetén, azonban ez biztosan nem jelenthető ki további vizsgálatok nélkül. Viszont a projektvezetők döntő többsége (több mint 85\%-a) még mindig fontosnak tartja a személyiségjegyek hatását a vezetési stílusra. A legtöbben úgy indokolták, hogy nem tudnak másként vezetni, mint ahogy személyiségükből adódik. Azonban többen megjegyezték az 5. vállalatból (és a 16. interjúalany is), hogy egy projektvezetőnek többféle vezetési stílus birtokában kell lennie, nem elég csupán egyet használni. Mindig projektcsapatfüggő. Ennek vizsgálata azonban szintén nem képezi a dolgozat tartalmát. 
Az eredmények ismeretében megállapítható, hogy az első hipotézis második fele valószínűsíthetőleg elfogadásra kell, hogy kerüljön, azonban ennek az egy lépésnek a fényében még nem jelenthető ki.

Ennek a résznek a második lépése a projektvezetői személyiségjegyek és a vezetési stílus együttes változását hivatott megvizsgálni. Azaz megkérdezésre került, hogy ha változtak a projektvezető személyiségjegyei (a korábban említett hat ${ }^{51}$ ), akkor változott-e a vezetési stílusa, ha igen, akkor miként. Azaz a 4/b kérdésre adott válasz utólag ellenőrzésre került, a változás leírásával csökkenthető annak az esélye, hogy a projektvezető hamisan ítélje meg a változás tényét. A változást a projektvezető leírhatta saját szóval (nőtt/csökkent/nem változott) vagy egy ötfokúskálán értékelhette az adott személyiségjegyet ${ }^{52}$. Természetesen előfordulhat a hamis korreláció, azaz lehet, hogy a személyiségjegy változott, de más faktor okozza a változást. Ilyenkor természetesen valamilyen mögöttes indokot kell keresni a változás mögött (vö. Babbie, 1994). Ennek kiszürésére lett feltéve a 4/b és a 4/h kérdés.

A projektvezetők által adott válaszokat a 25. táblázat foglalja magában:

\footnotetext{
${ }^{51}$ Bár a csapatépítő-képességre sokan nem adtak választ idő hiányában vagy egyéb okok miatt.

52 1-5 terjedő skálán értékelte a projektvezető az adott jellemzőt, ahol az 5 a legjobb, 1 legrosszabb. A viszonyítási alapot képező számot a projektvezető maga választhatta ki. Amennyiben változott, akkor elég volt csak a változás mértékét megadni.
} 
25. táblázat: A személyiségjegy és vezetési stílus változása vagy állandósága

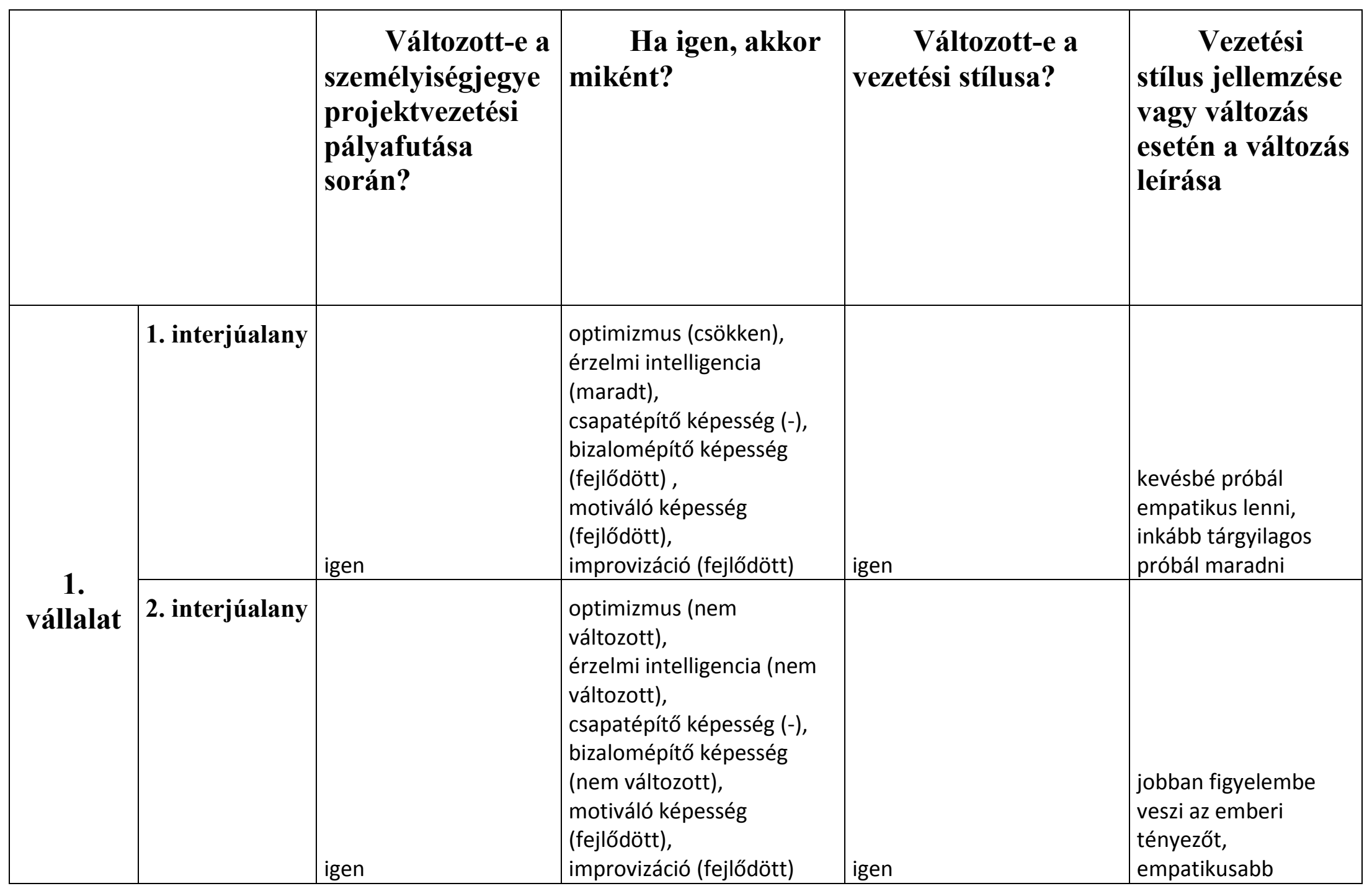




\begin{tabular}{|c|c|c|c|c|}
\hline 4. interjúalany & igen & $\begin{array}{l}\text { optimizmus (5), } \\
\text { érzelmi intelligencia (5), } \\
\text { csapatépítő képesség (-), } \\
\text { bizalomépítő képesség (3- } \\
>4), \\
\text { motiváló képesség (2->4), } \\
\text { improvizáció (4) }\end{array}$ & igen & empatikusabb \\
\hline 5. interjúalany & igen & $\begin{array}{l}\text { optimizmus (csökkent), } \\
\text { érzelmi intelligencia } \\
\text { (fejlődött), } \\
\text { csapatépítő képesség (-), } \\
\text { bizalomépítő képesség } \\
\text { (fejlődött), } \\
\text { motiváló képesség (nem } \\
\text { változott), } \\
\text { improvizáció (fejlődött) }\end{array}$ & igen & $\begin{array}{l}\text { tervközpontúból } \\
\text { emberközpontú, több } \\
\text { szabadság a } \\
\text { projektcsapat } \\
\text { tagjainak, de erős } \\
\text { kontrollt alkalmaz }\end{array}$ \\
\hline 6. interjúalany & igen & $\begin{array}{l}\text { optimizmus (csökkent), } \\
\text { érzelmi intelligencia } \\
\text { (fejlődött), } \\
\text { csapatépítő képesség (-), } \\
\text { bizalomépítő képesség (-), } \\
\text { motiváló képesség } \\
\text { (fejlődött), } \\
\text { improvizáció (-) }\end{array}$ & igen & $\begin{array}{l}\text { tervektől való eltérést } \\
\text { jobban el tudja } \\
\text { fogadni }\end{array}$ \\
\hline
\end{tabular}




\begin{tabular}{|c|c|c|c|c|}
\hline 7. interjúalany & 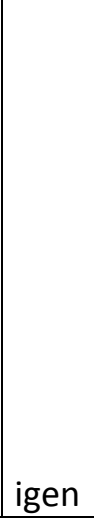 & $\begin{array}{l}\text { optimizmus (nem } \\
\text { változott), } \\
\text { érzelmi intelligencia (nem } \\
\text { változott), } \\
\text { csapatépító képesség (-), } \\
\text { bizalomépítő képesség } \\
\text { (nem változott), } \\
\text { motiváló képesség } \\
\text { (fejlődött), } \\
\text { improvizáció (nem } \\
\text { változott) }\end{array}$ & igen & $\begin{array}{l}\text { jobban figyelembe } \\
\text { veszi az emberi } \\
\text { tényezőt, } \\
\text { empatikusabb }\end{array}$ \\
\hline 8. interjúalany & igen & $\begin{array}{l}\text { optimizmus (nem } \\
\text { változott), } \\
\text { érzelmi intelligencia } \\
\text { (fejlődött), } \\
\text { csapatépítő képesség (-), } \\
\text { bizalomépítő képesség } \\
\text { (fejlődött), } \\
\text { motiváló képesség } \\
\text { (fejlődött), } \\
\text { improvizáció (fejlődött) }\end{array}$ & nem & $\begin{array}{l}\text { konszenzuskeresőbb } \\
\text { lett, } \\
\text { minden érvet integrál } \\
\text { a döntésbe } \\
\end{array}$ \\
\hline 9. interjúalany & igen & $\begin{array}{l}\text { optimizmus (fejlődött), } \\
\text { érzelmi intelligencia } \\
\text { (fejlődött), } \\
\text { csapatépítő képesség } \\
\text { (fejlődött), } \\
\text { bizalomépítő képesség } \\
\text { (fejlődött), } \\
\text { motiváló képesség } \\
\text { (fejlődött), } \\
\text { improvizáció (fejlődött) }\end{array}$ & igen & $\begin{array}{l}\text { határozottabb, } \\
\text { empatikusabb }\end{array}$ \\
\hline
\end{tabular}




\begin{tabular}{|c|c|c|c|c|c|}
\hline & $\begin{array}{l}10 . \\
\text { interjúalany }\end{array}$ & igen & $\begin{array}{l}\text { optimizmus (maradt), } \\
\text { érzelmi intelligencia } \\
\text { (fejlődött), } \\
\text { csapatépítő képesség (-), } \\
\text { bizalomépítő képesség } \\
\text { (fejlődött), } \\
\text { motiváló képesség (nem } \\
\text { változott), } \\
\text { improvizáció (fejlődött) } \\
\end{array}$ & igen & $\begin{array}{l}\text { türelmesebb, } \\
\text { emberközpontúbb, } \\
\text { gyorsabb } \\
\text { visszacsatolás }\end{array}$ \\
\hline & $\begin{array}{l}11 . \\
\text { interjúalany }\end{array}$ & igen & $\begin{array}{l}\text { optimizmus (nem } \\
\text { változott), } \\
\text { érzelmi intelligencia } \\
\text { (fejlődött), } \\
\text { csapatépítő képesség (-), } \\
\text { bizalomépítő képesség } \\
\text { (fejlődött), } \\
\text { motiváló képesség } \\
\text { (fejlődött), } \\
\text { improvizáció (nem } \\
\text { változott) }\end{array}$ & igen & $\begin{array}{l}\text { diplomatikus, de } \\
\text { szükség esetén már } \\
\text { képes keményebb } \\
\text { döntéseket is } \\
\text { meghozni }\end{array}$ \\
\hline $\begin{array}{c}2 . \\
\text { vállalat }\end{array}$ & $\begin{array}{l}12 . \\
\text { interjúalany }\end{array}$ & igen & $\begin{array}{l}\text { optimizmus (nem } \\
\text { változott), } \\
\text { érzelmi intelligencia } \\
\text { (fejlődött), } \\
\text { csapatépítő képesség (-), } \\
\text { bizalomépítő képesség } \\
\text { (fejlődött), } \\
\text { motiváló képesség } \\
\text { (fejlődött), } \\
\text { improvizáció (nem } \\
\text { változott) }\end{array}$ & igen & $\begin{array}{l}\text { kevésbé ragaszkodik } \\
\text { már a tervekhez, } \\
\text { érintett-központúbb }\end{array}$ \\
\hline
\end{tabular}




\begin{tabular}{|c|c|c|c|c|}
\hline $\begin{array}{l}13 . \\
\text { interjúalany }\end{array}$ & 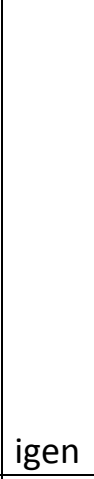 & $\begin{array}{l}\text { optimizmus (csökkent), } \\
\text { érzelmi intelligencia } \\
\text { (fejlődött), } \\
\text { csapatépítő képesség } \\
\text { (fejlődött), } \\
\text { bizalomépítő képesség } \\
\text { (fejlődött), } \\
\text { motiváló képesség } \\
\text { (fejlődött), } \\
\text { improvizáció (fejlődött) }\end{array}$ & igen & $\begin{array}{l}\text { érintettekre erősebb } \\
\text { hangsúly (főként } \\
\text { kommunikáció révén) }\end{array}$ \\
\hline $\begin{array}{l}14 . \\
\text { interjúalany }\end{array}$ & igen & $\begin{array}{l}\text { optimizmus (nem } \\
\text { változott), } \\
\text { érzelmi intelligencia } \\
\text { (fejlődött), } \\
\text { csapatépítő képesség (-), } \\
\text { bizalomépítő képesség (-), } \\
\text { motiváló képesség } \\
\text { (fejlődött), } \\
\text { improvizáció (fejlődött) }\end{array}$ & igen & $\begin{array}{l}\text { emberekhez való } \\
\text { hozzáállás változott }\end{array}$ \\
\hline $\begin{array}{l}15 . \\
\text { interjúalany }\end{array}$ & 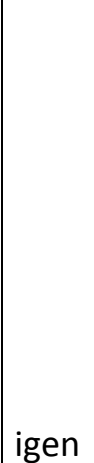 & $\begin{array}{l}\text { optimizmus (nem } \\
\text { változott), } \\
\text { érzelmi intelligencia } \\
\text { (fejlődött), } \\
\text { csapatépítő képesség (-), } \\
\text { bizalomépítő képesség } \\
\text { (fejlődött), } \\
\text { motiváló képesség } \\
\text { (fejlődött), } \\
\text { improvizáció (fejlődött) }\end{array}$ & igen & $\begin{array}{l}\text { jobban érintett } \\
\text { központúbb lett }\end{array}$ \\
\hline
\end{tabular}




\begin{tabular}{|c|c|c|c|c|c|}
\hline & $\begin{array}{l}16 . \\
\text { interjúalany }\end{array}$ & igen & $\begin{array}{l}\text { optimizmus (nem } \\
\text { változott), } \\
\text { érzelmi intelligencia } \\
\text { (fejlődött), } \\
\text { csapatépítő képesség (-), } \\
\text { bizalomépítő képesség } \\
\text { (fejlődött), } \\
\text { motiváló képesség } \\
\text { (fejlődött), } \\
\text { improvizáció (fejlődött) }\end{array}$ & igen & $\begin{array}{l}\text { jobban érintett } \\
\text { központúbb lett }\end{array}$ \\
\hline \multirow[b]{2}{*}{$\begin{array}{c}3 . \\
\text { vállalat }\end{array}$} & $\begin{array}{l}18 . \\
\text { interjúalany }\end{array}$ & 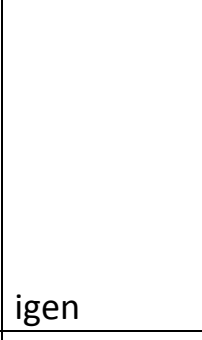 & $\begin{array}{l}\text { optimizmus (5), } \\
\text { érzelmi intelligencia (2->5), } \\
\text { csapatépítő képesség (3- } \\
>5 \text { ), } \\
\text { bizalomépítő képesség (5), } \\
\text { motiváló képesség (1->4), } \\
\text { improvizáció (5) }\end{array}$ & igen & emberközpontúbb \\
\hline & $\begin{array}{l}19 . \\
\text { interjúalany }\end{array}$ & finomodott & $\begin{array}{l}\text { optimizmus (nem } \\
\text { változott), } \\
\text { érzelmi intelligencia } \\
\text { (fejlődött), } \\
\text { csapatépítő képesség (-), } \\
\text { bizalomépítő képesség } \\
\text { (fejlődött), } \\
\text { motiváló képesség } \\
\text { (fejlődött), } \\
\text { improvizáció (fejlődött) }\end{array}$ & nem, csak finomodott & $\begin{array}{l}\text { jutalmazás } \\
\text { elsősorban, de ha kell, } \\
\text { akkor büntetés }\end{array}$ \\
\hline
\end{tabular}




\begin{tabular}{|c|c|c|c|c|}
\hline $\begin{array}{l}20 . \\
\text { interjúalany }\end{array}$ & igen & $\begin{array}{l}\text { optimizmus (nem } \\
\text { változott), } \\
\text { érzelmi intelligencia } \\
\text { (fejlődött), } \\
\text { csapatépítő képesség (-), } \\
\text { bizalomépítő képesség } \\
\text { (fejlődött), } \\
\text { motiváló képesség } \\
\text { (fejlődött), } \\
\text { improvizáció (fejlődött) }\end{array}$ & igen & kevésbé autoriter \\
\hline $\begin{array}{l}21 . \\
\text { interjúalany }\end{array}$ & 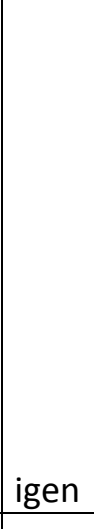 & $\begin{array}{l}\text { optimizmus (nem } \\
\text { változott), } \\
\text { érzelmi intelligencia } \\
\text { (fejlődött), } \\
\text { csapatépítő képesség (-), } \\
\text { bizalomépítő képesség } \\
\text { (fejlődött), } \\
\text { motiváló képesség } \\
\text { (fejlődött), } \\
\text { improvizáció (nem } \\
\text { változott) } \\
\end{array}$ & igen & $\begin{array}{l}\text { tervezőből inkább } \\
\text { kommunikáló }\end{array}$ \\
\hline $\begin{array}{l}22 . \\
\text { interjúalany }\end{array}$ & 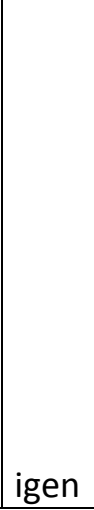 & $\begin{array}{l}\text { optimizmus (nem } \\
\text { változott), } \\
\text { érzelmi intelligencia (nem } \\
\text { változott), } \\
\text { csapatépítő képesség (-), } \\
\text { bizalomépítő képesség } \\
\text { (fejlődött), } \\
\text { motiváló képesség } \\
\text { (fejlődött), } \\
\text { improvizáció (nem } \\
\text { változott) }\end{array}$ & igen & $\begin{array}{l}\text { határozottabb lett } \\
\text { (előtte mindenkit } \\
\text { próbált megérteni) }\end{array}$ \\
\hline
\end{tabular}




\begin{tabular}{|c|c|c|c|c|c|}
\hline & $\begin{array}{l}23 . \\
\text { interjúalany }\end{array}$ & 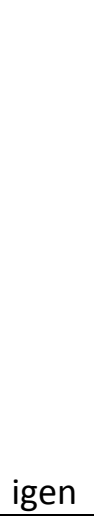 & $\begin{array}{l}\text { optimizmus (nem } \\
\text { változott), } \\
\text { érzelmi intelligencia } \\
\text { (fejlődött), } \\
\text { csapatépító képesség (-), } \\
\text { bizalomépítő képesség } \\
\text { (fejlődött), } \\
\text { motiváló képesség } \\
\text { (fejlődött), } \\
\text { improvizáció (nem } \\
\text { változott) }\end{array}$ & igen & - \\
\hline \multirow[b]{2}{*}{$\begin{array}{c}4 . \\
\text { vállalat }\end{array}$} & $\begin{array}{l}24 . \\
\text { interjúalany }\end{array}$ & nem & $\begin{array}{l}\text { optimizmus (2), } \\
\text { érzelmi intelligencia (4), } \\
\text { csapatépítő képesség (-), } \\
\text { bizalomépítő képesség (4), } \\
\text { motiváló képesség (4), } \\
\text { improvizáció (3) }\end{array}$ & nem & $\begin{array}{l}\text { elvárások } \\
\text { érzékeltetése }\end{array}$ \\
\hline & $\begin{array}{l}25 . \\
\text { interjúalany }\end{array}$ & 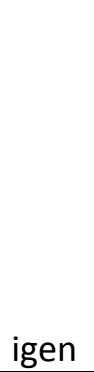 & $\begin{array}{l}\text { optimizmus (+1), } \\
\text { érzelmi intelligencia (+3), } \\
\text { csapatépítő képesség }(-), \\
\text { bizalomépítő képesség } \\
(+1), \\
\text { motiváló képesség }(+1), \\
\text { improvizáció (nem } \\
\text { változott) }\end{array}$ & igen & $\begin{array}{l}\text { eredményorientáltabb } \\
\text { lett }\end{array}$ \\
\hline
\end{tabular}




\begin{tabular}{|c|c|c|c|c|c|}
\hline \multirow{2}{*}{$\begin{array}{c}5 . \\
\text { vállalat }\end{array}$} & $\begin{array}{l}26 . \\
\text { interjúalany }\end{array}$ & igen & $\begin{array}{l}\text { optimizmus (nem } \\
\text { változott), } \\
\text { érzelmi intelligencia } \\
\text { (fejlődött), } \\
\text { csapatépítő képesség } \\
\text { (fejlődött), } \\
\text { bizalomépítő képesség } \\
\text { (fejlődött), } \\
\text { motiváló képesség } \\
\text { (fejlődött), } \\
\text { improvizáció (nem } \\
\text { változott) }\end{array}$ & igen & $\begin{array}{l}\text { több vezetési stílust } \\
\text { ismer, ezek között a } \\
\text { váltás gyorsabb } \\
\text { (demokratikus, } \\
\text { diktatorikus, kettő } \\
\text { közötti) }\end{array}$ \\
\hline & $\begin{array}{l}27 . \\
\text { interjúalany }\end{array}$ & 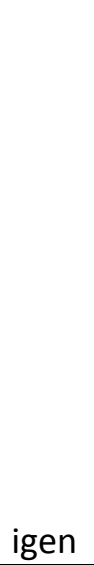 & $\begin{array}{l}\text { optimizmus (nem } \\
\text { változott), } \\
\text { érzelmi intelligencia } \\
\text { (fejlődött), } \\
\text { csapatépítő képesség } \\
\text { (fejlődött), } \\
\text { bizalomépítő képesség } \\
\text { (fejlődött), } \\
\text { motiváló képesség } \\
\text { (fejlődött), } \\
\text { improvizáció (nem } \\
\text { változott) }\end{array}$ & igen & $\begin{array}{l}\text { vállalati kultúrát } \\
\text { jobban figyelembe } \\
\text { veszi }\end{array}$ \\
\hline
\end{tabular}




\begin{tabular}{|c|c|c|c|c|}
\hline $\begin{array}{l}28 . \\
\text { interjúalany }\end{array}$ & igen & $\begin{array}{l}\text { optimizmus (csökkent), } \\
\text { érzelmi intelligencia } \\
\text { (fejlődött), } \\
\text { csapatépítő képesség } \\
\text { (fejlődött), } \\
\text { bizalomépítő képesség } \\
\text { (fejlődött), } \\
\text { motiváló képesség } \\
\text { (fejlődött), } \\
\text { improvizáció (fejlődött) }\end{array}$ & igen & $\begin{array}{l}\text { demokratikusabbá } \\
\text { vált }\end{array}$ \\
\hline $\begin{array}{l}29 . \\
\text { interjúalany }\end{array}$ & 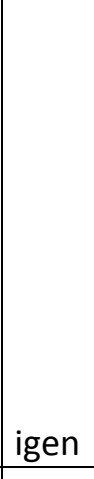 & $\begin{array}{l}\text { optimizmus (nőtt), } \\
\text { érzelmi intelligencia } \\
\text { (fejlődött), } \\
\text { csapatépítő képesség } \\
\text { (fejlődött), } \\
\text { bizalomépítő képesség } \\
\text { (fejlődött), } \\
\text { motiváló képesség } \\
\text { (fejlődött), } \\
\text { improvizáció (fejlődött) } \\
\end{array}$ & igen & $\begin{array}{l}\text { magabiztosabb, jobb } \\
\text { alkalmazkodás }\end{array}$ \\
\hline $\begin{array}{l}30 . \\
\text { interjúalany }\end{array}$ & igen & $\begin{array}{l}\text { optimizmus (nem változott) } \\
\text { érzelmi intelligencia } \\
\text { (fejlődött), } \\
\text { csapatépítő képesség } \\
\text { (fejlődött), } \\
\text { bizalomépítő képesség } \\
\text { (fejlődött), } \\
\text { motiváló képesség } \\
\text { (fejlődött), } \\
\text { improvizáció (csökkent) }\end{array}$ & igen & $\begin{array}{l}\text { határozottabb lett } \\
\text { (előtte mindenkit } \\
\text { próbált megérteni) }\end{array}$ \\
\hline
\end{tabular}




\begin{tabular}{|l|l|l|}
$\begin{array}{l}31 . \\
\text { interjúalany }\end{array}$ & $\begin{array}{l}\text { optimizmus (nem } \\
\text { változott), } \\
\text { érzelmi intelligencia (2->4), } \\
\text { csapatépítő képesség (2- } \\
>3), \\
\text { bizalomépítő képesség (3- } \\
>4), \\
\text { motiváló képesség (2->4), } \\
\text { improvizáció (nem } \\
\text { változott) }\end{array}$ & $\begin{array}{l}\text { igen } \\
\text { vállalati érdekeket } \\
\text { joban figyelembe } \\
\text { veszi, türelmesebb } \\
\text { lett }\end{array}$ \\
\hline igen &
\end{tabular}

Forrás: saját szerkesztés 
A válaszokból megállapítható, hogy 27 projektvezető szerint a személyiségjegyei változtak a projektvezetői pályafutása során. Ez némiképp ellentmond a korábban adott válasznak (hiszen 4-en azt mondták, hogy a személyiségjegyek nem változnak - ld. 23. táblázat), azonban ők úgy gondolták ebben az esetben, hogy nem változott, csupán finomodott, vagy a végleges változata a személyiségjegyeinek a projektvezetői pályafutása során alakult ki. Ezért az erre a kérdésre adott válaszukat el lehet fogadni, hiszen a finomodás is egyfajta változás, az pedig nem képezte a kutatás tartalmát, hogy a személyiségjegyeik mikor nyerték el jelenlegi állapotukat. Megállapítható továbbá, hogy egy olyan projektvezető volt, aki szerint nem változott a személyiségjegye a projektvezetői pályafutása során ${ }^{53}$, és kimondta explicite, hogy szerinte inkább csak finomodott. Annak, akinek nem változott a személyiségjegye a szakmai pályafutása során, annak a vezetési stílusa sem változott, maradt tervcentrikus (elvárások érzékeltetése). Aki szerint csak finomodtak a személyiségjegyei, az a projektvezető kiemelte, hogy a vezetési stílusa is csak finomodott, de alapvetően maradt a jutalmazó és szükség esetén büntető projektvezető.

A többiek esetén megfigyelhető a változás. Bár az optimizmus a legtöbb esetben nem változott (20 esetben), 5 esetben csökkent, 3 esetben pedig nőtt. Hasonló a helyzet az improvizáció esetén, ahol 15 esetben nem változott, 13 esetben nőtt, 1 esetben pedig csökkent, bár itt a statikusság jóval kevésbé markáns. Azonban az emberhez kapcsolódó személyiségjegyek esetén (érzelmi intelligencia, csapatépítő képesség, motivációs képesség, bizalomépítő képesség) mindenki változást tapasztalt pozitív irányba azok közül, akik szerint változott a személyiségjegyük. Ez a változás kihat a vezetési stílusukra is, hiszen vagy demokratikusabbak (tervközpontúbb, autoriterebb személy esetén) vagy autoriterebbek (túl empatikus személy esetén) lettek. Ez azt jelenti, hogy az emberhez kapcsolódó személyiségjegyek esetében a vezetési stílusra gyakorolt hatása jelentős lehet. Az, aki jobban meg tudta érteni a projektcsapat tagjait, határozottabb lett, az a személy, aki kevésbé, jóval emberközpontúbb. Természetesen ez nem azt jelenti, hogy a projektvezetők megegyező vezetési stílust követnek, hiszen számtalan apró részletben eltérhetnek.

53 Ö úgy ítélte meg, hogy a személyiségjegyek változása magával vonja a vezetési stílus és a projektvezetési szemléletmód változását, ami látszólag ellentmondás. Azonban elképzelhető (és a kérdések és válaszok alapján ezt kell feltételezni), hogy a projektvezetői pályafutása során nem változott a személyiségjegye, máskor változhat/változhatott. 
Három kivételt lehet azonosítani. Első kivételt a 8. interjúalany jelentette, aki szerint változtak a személyiségjegyei, de a vezetési stílusa nem változott (maradt olyan személy, aki igyekszik minél szélesebb perspektíva alapján dönteni). Azonban ő arra a kérdésre, hogy a személyiségjegyeinek változása esetén változna-e a vezetési stílusa és/vagy a projektvezetési szemléletmódja, azt válaszolta, hogy szerinte nem változhat a személyiségjegy. Ez ellentmond annak, hogy fejödést tapasztalt a személyiségjegyeiben. Ezen anomália miatt a 8. interjúalanyt célszerü kivenni a mintából a vezetési stílus vizsgálatának esetén. Második kivételt a 6 . projektvezető jelenti, aki nem emberközpontúbb lett, hanem kevésbé tervező, míg a harmadik kivételt a 16. projektvezető jelentette, aki eredmény-központúbb lett.

Összességében megállapítható tehát, hogy a személyiségjegyek változása esetén a vezetési stílus is változik, méghozzá az alapján, hogy milyen vezetési stílust követett a projektvezető a változás előtt. Abban az esetben, amikor a projektvezető autoriterebb volt, demokratikusabbá vált, azon esetben, amikor a projektvezető demokratikusabb volt, konszolidáltabb lett (ez persze nem azt jelenti, hogy a projektvezető ne lenne továbbra is érintett-központú, demokratikus). Amennyiben összevetjük a vezetési stílus kategóriákkal (vö. Fiedler, 1964; Müller - Turner, 2007), akkor az tapasztalható, hogy finomodott a feladat-központú vezetés, és jóval érintett-központúbbá vált, vagy érintett-központúvá vált feladat-központúból (kivéve a 6. és 16. projektvezető). Finomítva ezt a tág kategóriát, megállapítható, hogy az érzelmi intelligencián alapuló irányzat esetén inkább az edző, kapcsolatépítő vagy demokratikus projektvezetői szerepkört testesítik meg.

Ezek alapján megállapítható (köszönhetően annak, hogy 26 projektvezető esetén változtak vagy finomodtak a személyiségjegyek és így a vezetési stílus is változott vagy finomodott, míg 1 projektvezető esetén nem változott), hogy a negyedik hipotézis második fele nagy valószínűséggel elfogadható.

Az utolsó ellenőrzést ugyanaz a kérdés jelentette, mint a projektvezetői szemléletmód esetén, azaz ha változnának a személyiségjegyek, akkor változna-e a vezetési stílusa. A válaszok (és indoklásuk) megegyezik a projektvezetési szemléletmód esetén adottakkal, így kijelenthető, hogy 22 esetben változna, 4 esetben nem. 
Összességében tehát megállapítható, hogy a szemléletmód három kérdés esetén is azt igazolta, hogy annak hatása van a vezetési stílusra. Egyrészt 25 projektvezető tartotta úgy, hogy a szemléletmód hatást gyakorol a vezetési stílusra. Másrészt 26 projektvezető tartotta úgy, hogy változott a személyiségjegye szakmai pályafutása során, és ezzel párhuzamosan a vezetési stílusa is, míg egy esetén egyik kategóriában sem volt változás tapasztalható. Harmadrészt 22 projektvezető tartotta úgy, hogy a személyiségjegyének változása esetén változna a vezetési stílusa is.

Mindezek alapján kijelenthető, hogy a projektvezető személyiségjegyei hatást gyakorolnak a vezetési stílusra, így a negyedik hipotézis második fele, és ennek következtében a negyedik hipotézis elfogadható.

Kitekintésként megkérdezésre került, hogy a vezetési stílus, személyiségjegy és a projektvezetési szemléletmód felfogható-e háromszögként, azaz bármelyik változása magával vonzaná a másik kettő tényező változását. 17 projektvezető tartotta úgy, hogy ez felfogható háromszögként, 10 tartotta úgy, hogy nem, egy, hogy részben, 1 pedig nem adott rá választ. Ez alapján esély mutatkozik arra, hogy ezek kölcsönösen hatnak egymásra, azonban részletesebb vizsgálat nélkül ennek ellenkezője sem zárható ki.

\subsection{Következtetések}

Mindezek fényében megállapítható, hogy a projektvezető karakterisztikái jelentős hatást gyakorolt a projektsikerre (vö. Fortune - White, 2006). Azonban a projektvezetői jellemzők projektsikerre gyakorolt hatása fontos mind a gyakorlati szakemberek, mind az akadémiai élet számára. A kutatás során ezért azt került megvizsgálásra, hogy a projektvezető a kvalitatív vagy a kvantitatív eszközökkel tudja jobban biztosítani a sikert, a projektvezetési szemléletmódon belül az explicit vagy a tacit tudás válik dominánssá, a projektvezetési szemléletmód hatást gyakorole a projektsikerre, és végül, hogy a projektvezetői személyiségjegyek hatást gyakorolnak-e a projektvezetési szemléletmódra és a projektsikerre. A kutatás megállapította, hogy a hierarchikus modell (Görög, 2013a) tükrében kifejezett projektsikerre a kvantitatív eszközök nem gyakorolnak nagyobb hatást, mint a kvalitatívak. Megállapította továbbá, hogy a projektvezetési szemléletmódon belül az explicit tudás nincsen nagyobb mértékben jelen, mint a tacit. Az eredmények azt igazolják, hogy a projektvezetési szemléletmód a hierarchikus modell (Görög, 
2013a) szerint értelmezett projektsiker mindhárom szintjére hatást gyakorol. Valamint azt, hogy a projektvezetési szemléletmódra és a vezetési stílusra hatást gyakorol a projektvezető személyiségjegyei. Összefoglalva tehát a hipotézisek elvetése vagy elfogadása a következőképpen alakult:

H1: A kvantitatív projektvezetési eszközök nagyobb mértékben járulnak hozzá a projektsiker mindhárom szintjéhez, mint a kvalitatív projektvezetési eszközök.

\section{ELVETVE}

H2: A projektvezető projektvezetési szemléletmódján belül az explicit tudás nagyobb mértékben van jelen, mint a tacit tudás.

\section{ELVETVE}

H3: A projektvezető projektvezetési szemléletmódja befolyással bír a projektsiker mindhárom szintjére.

\section{ELFOGADVA}

H4: A projektvezető személyiségjegyei befolyással bírnak a projektvezető projektvezetési szemléletmódjára és a vezetési stílusára.

\section{ELFOGADVA}

Ez alapján megállapítható, hogy a projektvezető esetében a kvalitatív eszközök legalább olyan fontossággal bírnak, mint a kvantitatívak, valamint az, hogy a projektvezetési szemléletmód jelentős hatást gyakorol a projektsiker projektháromszög, projekttulajdonosi elégedettség és érintettek elégedettsége szerint értelmezett projektsikerre. Ráadásul a projektvezetési szemléletmódon belül a tacit tudás legalább olyan mértékben van jelen, mint az explicit. Ennek fényében kijelenthető, hogy a projektvezetési szemléletmód fejlesztése indokolt. Mivel megállapításra került, hogy a személyiségjegyek hatást gyakorolnak erre a projektvezetési karakterisztikára, ezért ennek fejlesztése is indokolt. Ráadásul ezen tényező a vezetési stílusra is hatással van, ami pedig kritikus sikertényező egy projekt esetén (vö. Fortune - White, 2006). Így a következő tézisek kerültek megfogalmazásra:

T1: A kvantitatív projektvezetési eszközök nem járulnak nagyobb mértékben hozzá a projektsiker három szintjéhez, mint a kvalitatív projektvezetési eszközök.

T2: A projektvezető projektvezetési szemléletmódján belül az explicit tudás nincs nagyobb mértékben jelen, mint a tacit tudás. 
T3: A projektvezető projektvezetési szemléletmódja befolyással bír a projektsiker mindhárom szintjére.

T4: A projektvezető személyiségjegyei befolyással bírnak a projektvezető projektvezetési szemléletmódjára és a vezetési stílusára.

Mindezek tükrében a disszertáció négy fontos megállapítást tartalmaz:

-A projektsiker elérésének jobb megértése révén a vállalatok növelhetik a sikeres projektjeik arányát.

- A projektvezetői tudásfejlesztés során a kvalitatív elemekre nagy hangsúlyt kell fektetni.

- A projektvezetői tudásfejlesztés során a projektvezetési szemléletmód fejlesztésére nagy hangsúlyt kell fektetni, méghozzá úgy, hogy a tacit tudás is átadható legyen.

- A projektvezetői tudásfejlesztés során a személyiségjegyek fejlesztésére is érdemes hangsúlyt fektetni, bár ennek fejlesztése nehézkes lehet.

Az első megállapítás értelmében a projektsiker elérésének jobb megértése révén a vállalatok növelhetik a projektek sikeres teljesítésének esélyét. A kutatás alapján megállapítható, hogy a kvalitatív eszközökre a projektek vezetése során nagy hangsúlyt kell fektetni. Továbbá a projektvezetési szemléletmód és az ennek fényében alkalmazott projektvezetési eszközök szintén nagy hatással bírnak a projektsikerre. Így a kvalitatív projektvezetési eszközök, a projektvezetési szemléletmód és az utóbbit befolyásoló (és egyben a vezetési stílusra is hatást gyakorló) személyiségjegyek kiemelt szerepet tölthetnek be a projektsiker biztosítása során.

A második megállapítás azt vonja magával, hogy az egyetemi oktatások vagy vállalati tréningek esetén nem csak a klasszikus, kvantitatív technikákat (mint pl. kockázatmenedzsment, költségtervezés) kell átadni, hanem a kvalitatívakra is nagy hangsúlyt kell fektetni (pl. kommunikációra, tartalmi-terjedelmi behatárolásra). Ez természetesen nem azt jelenti, hogy a kvantitatív eszközök ne bírnának fontossággal a projektsiker elérése során. Ennek a megállapításnak a fényében a kurzusok struktúrája finomodhat.

A harmadik megállapítás értelmében az egyetemi kurzusok és vállalati tréningek során a projektvezetési szemléletmódot is fejleszteni kell, a tacit elemek 
átadása által. Ehhez persze óhatatlanul szükséges, hogy olyan személy tartsa a képzést, aki képes ezt átadni, azaz rendelkezzen megfelelő szemléletmóddal. Arról, hogy melyik szemléletmód a megfelelő, nem lehet egyértelmüen állást foglalni. A kutatás alapján az érintett-centrikust követik a legtöbben, és annak fényében, hogy a projekteket a kutatás alapjául szolgáló vállalatok általában sikeresként könyvelik el, kijelenthető, hogy talán ennek a projektvezetési szemléletmódnak a kialakulását a legcélravezetőbb elösegíteni. Természetesen figyelembe kell venni a vállalati és iparági jellemzőket (vö. kontingencia-elmélet). Továbbá a második megállapítás értelmében nem elég a kvalitatív és kvalitatív eszközöket lexikonszerüen ismertetni, hanem törekedni kell a nehezen megtanulható elemek átadására is. Ezért célszerü olyan környezetet teremteni, olyan eszközöket alkalmazni az oktatás során (p1. szituációs játékok, esettanulmányok, oktatótermen kívüli feladatok), amelynek célja a projektvezetői szemléletmód fejlesztése és a tacit tudásátadás (vö. Horváth, 2013).

A negyedik megállapítás értelmében a projektvezető személyiségjegyeinek fejlesztésére is hangsúlyt kell fektetni, méghozzá föként azokra, amelyek az emberi tényezőhöz kapcsolódnak (érzelmi intelligencia, csapatépítő képesség, bizalomépítő képesség, motiváló képesség). Ezeknek fejlesztése nehézkes, és szintén hasonló elemekkel lehet, mint a tacit tudás átadását (vö. Horváth, 2013).

A második és harmadik megállapítás kombinációjaként (és figyelembe véve a kutatás eredményeit) célszerü lehet a személyiségjegyeket és a projektvezetési szemléletmódot olyan irányba fejleszteni, hogy érintett-centrikus (vagy ennek valamilyen leképeződése: edző, kapcsolatépítő, demokratikus) magatartást kövessen projektvezető. Természetesen itt figyelembe kell venni a kutatás korlátait, azaz a minta alapjául szolgáló cégek az ICT szektorban ténykednek. Ebből fakadóan nehezen elképzelhető, hogy egy építőiparban tevékenykedő projektvezető esetén ez a célravezető magatartás. Azonban ahol a környezet turbulens, a tudás és a projektcsapat elégedettsége fontos tényező, ott célszerü ezt alkalmazni. Ilyenre lehet további példa az IT vagy bankszektor, továbbá bármilyen kutatás-fejlesztési projekt.

Összességében megállapítható tehát, hogy az oktatás során (legyen az egyetemi kurzus vagy vállalati tréning) a nehezen fejleszthető elemek legalább olyan fontossággal bírnak, mint a klasszikus, kvantitatív ismeretek átadása, ezért az oktatók felelőssége lehet, hogy ezen elemek fejlesztésére is hangsúlyt fektessen. 


\subsection{A későbbi kutatások}

A kutatás erős limitációval bír, ezért a minta kiterjesztése mindenképpen indokolt. Célszerü eltérő karakterisztikájú vállalatokat is megvizsgálni, illetve más iparágakban ténykedőket is. Ezáltal a következtetések relevanciája növelhető.

Másik továbblépési lehetőség annak vizsgálata, hogy a projektvezetési szemléletmód milyen mértékben gyakorol hatást a projektsikerre. Annak vizsgálata is indokolt, hogy a szemléletmód milyen mértékü hatást gyakorol a vezetési stílusra és a projektvezetési szemléletmódra. Célszerü lehet továbbá azt is meghatározni, hogy mely’ tényezők játsszák a legnagyobb szerepet a projektvezetési szemléletmód és vezetési stílus kialakulásában. Ugyanis ennek fejlesztése is indokolttá válhat.

Azonban a legfontosabb továbblépés mindenképpen az, hogy ezek az eredmények megvalósításra kerüljenek egy kurzus esetén. A kurzus során pedig ki kell dolgozni olyan oktatási anyagot, amely a kvalitatív és a tacit ismeretátadásra, valamint a projektvezetői szemléletmód és a személyiségjegy fejlesztésére helyezi a hangsúlyt. Szükséges megjegyezni, hogy a jelenleg oktatott projektvezetés kurzusok kiváló alapot képeznek ehhez, azonban úgy vélem, hogy tovább lehet még ezt is fejleszteni a korábban említett elemek tükrében.

\section{7 Összefoglalás}

Kutatásom alapvető célkitüzése az volt, hogy lehetővé tegye a projektsiker elérésének jobb megértését.. Részletesebben az, hogy kimutassam, a kvalitatív eszközök, a tacit tudás (közvetve), a projektvezetési szemléletmód és közvetve a személyiségjegy legalább olyan mértékben gyakorol hatást a projektsikerre, mint a klasszikus, kvantitatív elemek és ismeretek. Ennek gyakorlati haszna pedig az oktatási kurzusok és vállalati tréningek fejlesztése során mutatkozhat meg. Ehhez négy kérdéskört vizsgáltam meg:

KK1: Milyen mértékben járulnak hozzá a kvalitatív és kvantitatív projektvezetési eszközök a projektsiker három szintjéhez?

KK2: Milyen jellegü (explicit, tacit) tudás van nagyobb mértékben jelen a projektvezető projektvezetési szemléletmódjában? 
KK3: Gyakorol-e számottevő hatást a projektvezető projektvezetési szemléletmódja a projektsiker három szintjére?

KK4: Gyakorolnak-e számottevő hatást a személyiségjegyek a projektvezető projektvezetési szemléletmódjára és a vezetési stílusára?

Az első kérdésre (hipotézis formájában) azt a választ kaptam, hogy a kvalitatív eszközök legalább olyan mértékben járulnak hozzá a projektsikerhez, mint a kvantitatív eszközök. A második kérdésre (hipotézis formájában) azt a választ kaptam, hogy a tacit tudás legalább olyan mértékben van jelen a projektvezetési szemléletmódon belül, mint az explicit. A harmadik kérdésre azt a választ kaptam (hipotézis formájában), hogy a projektvezetési szemléletmód a projektsiker mindhárom szintjére hatással van. Míg a negyedik kérdésre (hipotézis formájában) azt a választ kaptam, hogy a személyiségjegyek hatással vannak a projektvezetési szemléletmódra és vezetési stílusra. A gyakorlati eredményeket az 5.4. fejezet összegzi.

Azonban ahhoz, hogy ezek a kutatási kérdések (és az ebből származtatott hipotézisek) megfogalmazásra kerüljenek, a szakirodalom áttekintése óhatatlanul szükségessé vált. A szakirodalom során a projekt és projektvezetői szerepkör értelmezésének fejlődéséhez, a projektsikerhez, a sikerkritériumokhoz, a kritikus sikertényezőkhöz, a projektvezetői tudáshoz (különös tekintettel a projektvezetési szemlélethez és explicit/tacit tudás jellegéhez), a személyiségjegyekhez és vezetési stílushoz kapcsolódó szakirodalom került feldolgozásra.

A bevezetésben bemutatásra került a projektsiker alacsony aránya, az ezzel foglalkozó vizsgálatok fontossága, a dolgozat célkitűzései és tartalma.

Értekezésem második fejezetében a projekt és projektvezetői szerepkör értelmezésének fejlődése került áttekintésre. Ennek főbb megállapításai a következők:

- A projekt értelmezése megváltozott, ma már nem elégséges egyedi feladatként definiálni egy projektet, hanem szükséges ideiglenes szervezetként és stratégiai építőelemként is tekinteni arra.

-Ebből fakadóan a projektvezető szerepe is megváltozott, hiszen a kezdeti, projektteljesítési folyamatának vezetése helyett már óhatatlanul szükséges, hogy az 
ideiglenes szervezetet is vezesse (föként a projektcsapatot) és a projekt révén elérendő kedvezető stratégiai változást is elősegítse.

-Összegyüjtésre kerültek a projekt szakaszai, és ennek fényében a projektvezető főbb feladatai (összhangban az előző ponttal).

Értekezésem harmadik fejezetében a projektsikerhez kapcsolódó szakirodalom került összegyüjtésre. Ennek főbb megállapításai a következők:

- A projektsiker értelmezése összhangban fejlödött a projekt értelmezésének fejlődésével.

- A projektsiker értékelése során a megfelelő értékelési módszer a hierarchikus modell (Görög, 2013a). A többi modell - megítélésem szerint - komolyabb hiányossággal bír, mint ez a modell.

- A kritikus sikertényezők szakirodalma igen bö, azonban 9 nagyobb csoportot lehet képezni belölük, aminek egyik csoportja a projektvezető kompetenciája és (vezetési) stílusa.

- A kritikus sikertényezőkkel foglalkozó szakirodalom négy jelentős hiányossággal bírnak, úgymint:

○ A kritikus sikertényezők fontossága a projekt előrehaladtával változhat.

○ A kritikus sikertényezők egymás közötti kölcsönhatása nem kerül figyelembevételre.

○ A kritikus sikertényezők létjogosultsága megkérdőjelezhető, hiszen nehéz általános érvényűeket azonosítani.

○ A kritikus sikertényezők nem veszik figyelembe a sikerkritériumokat a projektsikerre gyakorolt hatás vizsgálata során.

- A kritikus sikertényezők és sikerkritériumok összehangolását taglaló szakirodalom kevés, és többségük túl általánosan, hiányosan vagy nem megfelelő mélységben kezeli ezt a kérdést.

A negyedik fejezet a projektvezető elvárt tudásával, személyiségjegyeivel és vezetési stílusával foglakozik. Ennek főbb megállapításai a következők:

- A projektvezető elvárt tudása, személyiségjegye és vezetési stílusa kiemelten fontos a projektsiker elérése során, hiszen ez a szereplő markáns hatást gyakorol a sikerre a projekt minden szakaszában. 
- A projektvezető tudásának vizsgálata során megfelelő elméleti alapot jelent Cleland (1994) képességmodellje.

- A projektvezető tudásán belül értelmezett projektvezetési szemléletmódot a szakirodalom hiányosan kezeli. Megállapításra került, hogy a kutatás alapjául a projekt és projektvezetés értelmezésének fejlődése szerint szemléletmód-értelmezés szolgált.

-A projektvezető személyiségjegyeinek szakirodalma igen szükös, ráadásul sokszor nem különböztetik meg a személyiségjegyet a kompetencián belül. Holott az egyik a projektvezető tudását, tanult ismeretét jelenti, míg a másik az ezen tudás jobb vagy rosszabb használatához szükséges egyedi jellemzőket jelenti. Így a kutatás során az elméleti alapot Görög (2013a) hatos személyiségjegy-csoportja jelentette, amely nem tanult ismereteket, hanem valódi személyiségjegyeket tartalmaz.

- A projektvezetési eszközök projektsikerre gyakorolt hatását taglaló szakirodalom hiányos. Bár a szakirodalom azonosítja azokat az eszközöket, amik hathatnak a projektsikerre, azonban ezeket nem megfelelő mélységben teszi.

- A projektvezető vezetési stílusának szakirodalma jelentős fejlődésen esett át, ahol a kezdeti, személyes vonásokon alapuló értelmezés mellett egyre inkább megjelent az érintett-centrikus és egyéb vezetési stílusokkal foglakozó szakirodalom. Azonban a vezetési stílusra hatást gyakorló faktorok irodalma igencsak korlátozott, és az is inkább kompetencia alapú, ebből fakadóan nem különbözteti meg ezen belül a személyiségjegyet.

Mindezek alapján a következő főbb megállapításokat lehet tenni:

- A projektvezető karakterisztikáinak projektsikerre gyakorolt hatását célszerü megvizsgálni.

- A projektvezetői karakterisztika mint kritikus sikertényező vizsgálata során figyelembe kell venni a kritikus sikertényezők szakirodalmának hiányosságait.

- A projektvezető projektvezetési szemléletmód projektsikerre gyakorolt hatásának feltérképezésére a szakirodalomban nincs példa.

-A projektvezetési szemléletmódra és a vezetési stílusra hatást gyakorló faktorok azonosítása hiányos vagy nem megfelelő.

- A kvalitatív és kvantitatív projektvezetési eszközök projektsikerre gyakorolt hatásának feltérképezése korlátozott. 
- A tacit és explicit tudás a projektvezető elvárt képességein belüli megjelenését vizsgáló szakirodalom korlátozott.

Az ötödik fejezet összegzi a kutatást. A kutatás során négy hipotézis került felállításra (az elmélet és a korábban taglalt kutatási kérdések alapján), úgymint:

H1: A kvantitatív projektvezetési eszközök nagyobb mértékben járulnak hozzá a projektsiker mindhárom szintjéhez, mint a kvalitatív projektvezetési eszközök.

H2: A projektvezető projektvezetési szemléletmódján belül az explicit tudás nagyobb mértékben van jelen, mint a tacit tudás.

H3: A projektvezető projektvezetési szemléletmódja befolyással bír a projektsiker mindhárom szintjére.

H4: A projektvezető személyiségjegyei befolyással bírnak a projektvezető projektvezetési szemléletmódjára és a vezetési stílusára.

A hipotézis elfogadásához vagy elvétéséhez a kutatás mintájának alapjául az ICT szektorban tevékenykedő multinacionális cégek leányvállalati szolgáltak. Öt lett kiválasztva belölük szakértői becslés alapján, különös figyelemmel arra, hogy a piac vezető szereplői legyenek. Ezen öt vállalat projektvezetői közül 31 lett kiválasztva a véletlen mintavételi eljárás alapján.

A kutatás során kiderült, hogy 29 képezheti a mintát, hiszen kettőnek a tudása nem elégséges releváns következtetések levonásához.

A kutatás során a következő főbb megállapítások kerültek megfogalmazásra:

-A projektvezetők kvantitatív projektvezetési eszközei nem járulnak nagyobb mértékben hozzá a sikerhez (amelyet a hierarchikus modell alapján értelmeztem), mint a kvalitatív projektvezetési eszközök. Annak ellenére sem, hogy a projektháromszög szerinti sikeresség esetén a tisztán kvantitatív eszközöket tartalmazó tevékenységeket, azaz a tervezést (28 esetben lett említve) és a kontrollt (23) többször említették a projektvezetők, mint a tisztán kvalitatívakat, azaz kommunikációt (20 esetben lett említve) és az érintettek kezelését ( 7 esetben lett említve). Annak a ténynek köszönhetően, hogy a kommunikációt alkalmazó projektvezetők szerint a kommunikáció legalább annyira fontos, mint a tervezés, nem jelenthető ki, hogy a kvantitatív elemek fontosabbak lennének. A projekttulajdonosi elégedettség szerinti sikerességhez a kvantitatív elemek egyértelmüen nem járulnak 
hozzá nagyobb mértékben, mint a kvalitatívak (tisztán kvantitatív eszközöket tartalmazó tevékenységeket már nem említettek). Az érintettek elégedettsége szerinti sikeresség esetén is hasonló az eredmény (bár itt kétszer meg lett említve a kontroll). Azaz nem jelenthető ki, hogy a kvantitatív eszközök nagyobb mértékben járulnak hozzá a projektsiker mindhárom szintjéhez, mint a kvalitatív eszközök.

- A választ adott projektvezetők mindegyike (28 fö) úgy tartotta, hogy az alkalmazott projektvezetési szemléletmódjának tükrében alkalmazza a kvalitatív és kvantitatív projektvezetési eszközöket. Továbbá 27 projektvezető tartotta úgy, hogy az eszközök fejlödtek a gyakorlati tapasztalatának hatására, csupán egy úgy tartja, hogy nem. Emellett a válaszadók mindegyike úgy véli, hogy az eszköz inkább elsajátítható, mint tanulható. Bár többen kiemelték, hogy az elméleti megalapozottság fontos. Ennek fényében kijelenthetö, hogy a projektvezetési szemléletmódon belül az explicit tudás nincs jelen nagyobb mértékben, mint a tacit tudás.

- A projektvezetők döntő többsége tartotta úgy, hogy az általa alkalmazott projektvezetési szemléletmód hatással van a projektháromszög szerint értelmezett sikerességre (21 fö), a projekttulajdonosi elégedettség szerinti sikerességre (25 fó) és az érintettek elégedettsége szerinti sikerességre (24 fö). Ráadásul 17 projektvezető szerint a projektvezetési szemléletmódja a projektsiker mindhárom szintjére hatással van, míg csupán 5 úgy, hogy nem. Így kijelenthető, hogy a szemléletmód hatást gyakorol a projektsiker mindhárom szintjére.

-Végezetül a projektvezetők szerint a személyiségjegyeinek hatása van a projektvezetési szemléletmódra és a vezetési stílusra. Mind a 29 projektvezető megnevezte a személyiségjegyeit mint tényezőt, amely hatott a projektvezetési szemléletmódjának kialakulására. Ezt erösítendő, megkérdezésre került, hogy szerinte, ha változna a személyiségjegye, változna-e a projektvezetési szemléletmódja is. 22 projektvezető szerint igen, 4 szerint nem. A vezetési stílus esetében 25 projektvezető gondolta úgy, hogy a személyiségjegyei közrejátszottak a vezetési stílusának kialakulásában. Ezután megkérdezésre került, hogy a projektvezető személyiségjegye változott-e a szakmai pályafutása során, és amennyiben igen, változott-e a vezetési stílusa, amennyiben nem, akkor maradt-e állandó. Egy projektvezető gondolta úgy, hogy nem változott a személyiségjegye, és neki állandó maradt a vezetési stílusa is. Míg 28 gondolta úgy, hogy változott a személyiségjegye szakmai pályafutása során. Közülük 26 gondolta úgy, hogy 
változott a vezetési stílusa, 1 nem, 1 szerint pedig csak finomodott. A változás fó irányvonala az érintettekhez kapcsolódik, hiszen egyfelöl a hozzájuk kapcsolódó személyiségjegyek változtak a leginkább (érzelmi intelligencia, csapatépítő képesség, motivációs képesség, bizalomépítő képesség), másfelől pedig a vezetési stílusuk változása is az érintettekhez való viszonyban mutatkozott meg a leginkább. Azok, akik túl demokratikusak voltak, kicsit autoriterebbek lettek, azok, akik autoriterek voltak, demokratikusabbak lettek. Végül fel lett téve ellenőrzésnek az a kérdés, ami a projektvezetési szemléletmód esetén, azaz a személyiségjegyeinek változása magával vonzaná-e a vezetési stílusának változását is. A válaszadási arány megegyezett az előzővel, azaz 22 gondolta úgy, hogy igen, 4 úgy, hogy nem. Ezek fényében kijelenthető, hogy a projektvezető személyiségjegyei hatással vannak a projektvezetési szemléletmódjára és vezetési stílusára.

- Mindezek fényében az első két hipotézis elvetésre, a második kettő elfogadásra került.

Bár a kutatásnak komoly limitációi vannak (csupán egyetlen iparág 5 vállalata lett megvizsgálva), azonban az eredményei támpontot jelenthetnek az akadémiai kurzusok és vállalati tréningek során. A kutatás eredményei alapján a kvalitatív eszközök és a tacit tudás átadására is hangsúlyt kell helyezni, csakúgy, mint a projektvezetési szemléletmód és a személyiségjegy fejlesztésére. Bízom benne, hogy ezáltal a kurzusok színvonala tovább emelkedhet. A kutatás egyik jelentős továbblépése lehet ennek a kurzusnak a kifejlesztése. 


\section{Irodalomjegyzék}

1. Aljaz, S. (2013): Agile Project Management - A Future Approach to the Management of Projects?; Dynamic Relationship Management Journal, 2(1), pp. 43-54.

2. Antal-Mokos et al. (2003): Stratégia és szervezet. Budapest, KJKKERSZÖV jogi és üzleti kiadó.

3. Al-Ahmad, W. - Al-Fagih, K. -Khanfar, K. -Alsamara, K. -Abuleil, S. -Abu-Salem, H. (2009): A Taxonomy of an IT Project Failure: Root Causes, International Management Review, 5(1), pp. 93-106. DOI: http://dx.doi.org/10.1016/j.procs.2013.09.280

4. Agarwal, N. - Rathod, U. (2006): Defining 'success' for software projects: An exploratory revelation. International Journal of Project Management, 24(4), pp. 358-370. DOI: http://dx.doi.org/10.1016/j.ijproman.2005.11.009

5. Ahadzie et al. (2008): Critical success criteria for mass house building projects in developing countries. International Journal of Project Management, 26(6), pp. 675-687. DOI: http://dx.doi.org/10.1016/j.ijproman.2007.09.006

6. Ahadzie, D. - Proverbs, D.G. - Olomolaiye, P.O. - Ankrah, N.A.( 2009): Competencies required by project managers for housing construction in Ghana. Engineering, Construction and Architectural Management, 16(4), pp. 353375.

7. Anantatmula, V. S. (2008) The Role of Technology in the Project Manager Performance Model. Project Management Journal, 39(1), pp 34-48. DOI: http://dx.doi.org/10.1002/pmj.20038

8. Apella, J. (2011): Management 3.0: Leading Agile Developers, Developing Agile Leaders. Addison-Wesley Professional, Indianapolis.

9. Atkinson, R. (1999): Project management: cost, time and quality, two best guesses and a phenomenon, its time to accept other success criteria. International Journal of Project Management 17(6), pp. 337-342. DOI: http://dx.doi.org/10.1016/S0263-7863(98)00069-6

10. Baccarini, D. (1999): The Logical Framework Method for Defining Project Success. Project Management Journal 30(4), pp. 25-32. DOI: http://dx.doi.org/10.1257/0002828041464551 
11. Bakacsi, Gy. (2004): Szervezeti magatartás és vezetés. Aula Kiadó, Budapest.

12. Belassi, W. - Tukel, O. (1996): A new framework for determining critical success-failure factors in projects, International Journal of Project Management 14(3), pp. 141-151. DOI: http://dx.doi.org/10.1257/0002828041464551

13. Berce, J. (1998) Managing a Multi-Level Project. in: Proceedings of the 14th World Congress on Project Management. Ljubljana, Szlovénia. In: Görög, M. (2007): A projektvezetés mestersége. Aula Kiadó, Budapest.

14. Bignell, V. - Fortune, J. (1984): Understanding systems failures. University of Manchester Press, Manchester. In: Fortune, J. - White, D. (2006): Framing of project critical success factors by a system model. International Journal of Project Management, 24(1), pp. 53-65.

15. Black, C., Akintoye, A. - Fitzgerald, E. (2000): An analysis of success factors and benefits of partnering construction International Journal of Project Management, 18(1), pp. 423-434. DOI: http://dx.doi.org/10.1016/S02637863(99)00046-0

16. Blaskovics, B. (2014): Aspects of projects success - The case of a multinational company. PMUni Conference Vienna, 14.05.2014.

17. Bredillet, C (2007).: From the Editor. Project Management Journal, 38(2), pp. 3-4.

18. Briére, S. - Proulx, D. - Flores, D. P. - Laporte, M. (2014): Competencies of project managers in international NGOs: Perceptions of practitioners. International Journal of Project Management. [A PhD írásának pillanatában csak elektronikusan volt elérhető]. DOI: http://dx.doi.org/10.1016/j.ijproman.2014.04.010

19. Bryde, D.J. (2008): Perceptions of the impact of project sponsorship practices on project success. International Journal of Project Management 26(8), pp.800-809. DOI: http://dx.doi.org/10.1016/j.ijproman.2007.12.001

20. Bryde, D. J. - Robinson, L. (2005): Client versus contractor perspectives on project success criteria. International Journal of Project Management 23(8), pp. 622-629. DOI: http://dx.doi.org/10.1016/j.ijproman.2005.05.003

21. Bower, D. C. - Walker, D. H. T. (2007): Planning Knowledge for Phased Rollout Projects. Project Management Journal, 38(3), pp 45-60. DOI: http://dx.doi.org/10.1002/pmj.20005 
22. Boyatzis, R.E. (1982). The competent manager: a model for effective performance. New York, Wiley.

23. Buttrick, R. (2000): The project workout: a toolkit for reaping the rewards from all your business projects. London: Prentice Hall

24. Chickán, A. - Czakó, E. (2009): Versenyben a világgal. Aula Kiadó, Budapest.

25. Chen, W. T. - Chen, T. (2007): Critical success factors for construction partnering in Taiwan. International Journal of Project Management, 25(5), pp. 475-484. DOI: http://dx.doi.org/10.1016/j.ijproman.2006.12.003

26. Chen, P. - Partington, D. - Qiang, M. (2009): Cross-Cultural Understanding of Construction Project Managers' Conceptions of Their Work. Journal of Construction Engineering and Management, 135(6), pp. 477-487. DOI: http://dx.doi.org/10.1061/(ASCE)CO.1943-7862.0000009

27. Cheung, S. O., Yiu, T. W. - Chiu, O. K. (2009): The aggressivecooperative drivers of construction contracting. International Journal of Project Management, 27(7), pp. 727-735. DOI: http://dx.doi.org/10.1016/j.ijproman.2008.09.001

28. Cicmil, S. (1999) An insight into management of organizational change projects. Journal of Workplace Learning, 11(1), pp 5-15.

29. Clark, A. (1998). The Redemptive Work: Railway and Nation in Ecuador, 1895-1930. Wilmington, DE: Scholarly Resources.

30. Clarke, N. (2010) The impact of a training programme designed to target the emotional intelligence abilities of project managers. International Journal of Project Management, 28(5), pp 461-468 DOI: http://dx.doi.org/10.1016/j.ijproman.2009.08.004

31. Cleland, D. I. (1994) Project Management - Strategic Design and Implementation (2nd ed.) New York, McGraw-Hill

32. Cleland, D. I. (1995): Leadership and the project management body of knowledge. International Journal of Project Management, 13(1), pp. 83-88. DOI: http://dx.doi.org/10.1016/0263-7863(94)00018-8

33. Cleland, D. I. - Ireland, L. (2002). Project management: Strategic design and implementation McGraw-Hill, New York.

34. Clements, J. P. - Gido, J. (2006) Effective Project Management. Thomson, Intl. 
35. Cloninger, C. R. (1994): The temperament and character inventory (TCI): A guide to its development and use. St. Louis, MO: Center for Psychobiology of Personality, Washington University.

36. Cooke-Davies, T. (2002): The "real" success factors on projects. International Journal of Project Management, 20(3), pp. 185-190. DOI: http://dx.doi.org/10.1016/S0263-7863(01)00067-9

37. Crawford, L. - Nahmias, A. H. (2010): Competencies for managing change. International Journal of Project Management, 28(4), pp. 352-360. DOI: http://dx.doi.org/10.1016/j.ijproman.2010.01.015

38. Crawford, L. - Pollack, J. (2004): Hard and soft projects: A framework for analysis. International Journal of Project Management, 22, pp 645653. DOI: http://dx.doi.org/10.1016/j.ijproman.2004.04.004

39. Cserháti, G. - Szabó, L. (2014): The relationship between success criteria and success factors in organisational event projects. International Journal of Project Management, 32(4), pp. 613-624. DOI: http://dx.doi.org/10.1016/j.ijproman.2013.08.008

40. Davenport, T. H. - Prusak, L. (1998): Working Knowledge - How Organizations Manage What They Know. Harvard Business School Press, Watertown.

41. Deák, Cs. (2001): Változás, változtatás, újjáalakítás a mai magyar vállalati gyakorlatban. $\mathrm{ME} \mathrm{PhD-értekezés.}$

42. de Bakker, K., Boonstra, A. - Wortmann, H. (2010): Does risk management contribute to IT project success? A meta-analysis of empirical evidence. International Journal of Project Management, 28(5), pp. 493-503. DOI: http://dx.doi.org/10.1016/j.ijproman.2009.07.002

43. de Dreu, C. K. W. (2008): The virtue and vice of workplace conflict: food for (pessimistic) thought. Journal of Organizational Behavior, 29(1), pp. 5-18. DOI: http://dx.doi.org/10.1002/job.474

44. de Wit, A. (1988) Measurement of project success. International Journal of Project Management, 6(3), pp. 164-170. DOI: http://dx.doi.org/10.1016/0263-7863(88)90043-9

45. Dobák, M. (2006): Szervezeti formák és vezetés. Akadémia Kiadó, Budapest. 
46. Doloi, H., Iyer, K. C. - Sawhney, A. (2011): Structural equation model for assessing impacts of contractor's performance on project success. International Journal of Project Management, 29(6), pp. 687-695. DOI: http://dx.doi.org/10.1016/j.ijproman.2010.05.007

47. Dogbegah, R. - Owusu-Manu, D. - Omoteso, K.(2011): A principal componentanalysis of project management competencies for the Ghanaian construction industry. Australasian Journal of Construction Economics and Building, 11(1), pp. 26-40. DOI: http://dx.doi.org/10.5130/ajceb.v11i1.1680

48. Dulewicz, V. - Higgs M., J. (2003): Design of a new instrument to assess leadership dimensions and styles. Henley Working Paper Series HWP

49. Earl, M. J. (1989): Management Strategies for Information Technology. Prentice Hall

50. Earl, M. J. (1996): Information Management: The Organizational Dimension. Oxford University Press

51. Edum-Fotwe, F.T. - McCaffer, R. (2000): Developing project management competency: perspectives from the construction industry. International Journal of Project Management, 18(2), pp. 111-124. DOI: http://dx.doi.org/10.1016/S0263-7863(98)90075-8

52. Eilat et al. (2008): R\&D project evaluation: An integrated DEA and balanced scorecard approach. Omega, 36(5), pp. 895-912. DOI: http://dx.doi.org/10.1016/j.omega.2006.05.002

53. El-Sabaa, S.(2001): The skills and career path of an effective project manager. International Journal of Project Management, 19(1), pp. 1-7. DOI: http://dx.doi.org/10.1016/S0263-7863(99)00034-4

54. Evans, P. (2000): Strategy, the end of the game. Journal of Business Strategy, 21(6), pp. 12-16. DOI: http://dx.doi.org/10.1016/S0263-7863(98)00069-6

55. Fehér, P. (2004): Tudásmenedzsmentet támogató tényezők szerepe a szoftverfejlesztő szervezetekben. PhD értekezés, Budapesti Corvinus Egyetem.

56. Fehér, P. (2008): IT Stratégia. Elöadás, 2008. október 27-én.

57. Fekete, I. (2000) A kockázatelemzés szerepe a beruházások pénzáramlásának meghatározásában. $\mathrm{PhD}$ értekezés, Budapest Műszaki és Gazdaságtudományi Egyetem DOI: http://dx.doi.org/10.1016/S0263-7863(98)000696 
58. Fekete, I. - Dobreff, Cs. (2003): Távközlési projektmenedzsment. Mủegyetemi Kiadó, Budapest. DOI

59. Fiedler, F.E. (1967): A Theory of Leadership Effectiveness. McGrawHill, New York.

60. Fiedler, S. (2010): Managing resistance in an organizational transformation: A case study from a mobile operator company. International Journal of Project Management, 28(4), pp. 370-383. DOI: http://dx.doi.org/10.1016/j.ijproman.2010.02.004

61. Fortune, J. - White, D. (2006): Framing of project critical success factors by a system model. International Journal of Project Management, 24(1), pp. 53-65. DOI: http://dx.doi.org/10.1016/j.ijproman.2005.07.004

62. FOVOSZ (2012): Projektmenedzsment az állam és közigazgatásban. [Letöltve: 2013. április 22-én]. Elérhető: http://www.fovosz.hu/doc/OKT/PM_Kezikonyv.pdf

63. Frame, J.D. (1987): Managing Projects in Organizations. Jossey Bass, California.

64. Freeman, M. - Beale, P. (1992), "Measuring project success", Project Management Journal, 23(1), pp.8-17.

65. Gaddis, P. O. (1959) The project manager. Harvard Business Review, 37(2), pp. 89-97.

66. Gareis, R. (2008): Research: Sustainability \& Project Management. PMUni koferencia, Budapest, November 24-e

67. Gareis, R. (2010a): Sustainable Project Management. PMUni konferencia, Bécs, Május 26-a.

68. Gareis, R. (2010b): Sustainable Project Management. Eden doctoral seminar, Lille, Augusztus 16-a.

69. Gardiner, P.D. - Stewart, K. (2000): Revisiting the golden triangle of cost, time and quality: the role of NPV in project control, success and failure. International Journal of Project Management 18(4), pp. 251-256. DOI: http://dx.doi.org/10.1016/S0263-7863(99)00022-8

70. Gelbard, R. - Carmeli, A. (2009): The interactive effect of team dynamics and organizational support on ICT project success. International Journal of Project Management, 27(5), pp. 464-470. DOI: http://dx.doi.org/10.1016/j.ijproman.2008.07.005 
71. Gemünden, H. G. - Zöldréti, A. - Lechler, T. (1990) A projektmenedzsment sikerfaktorai - az empirikus vizsgálatok számbavétele alapján. Ipar - Gazdaság, XLIII(11-12), pp 15-25.

72. Goleman, D. - Boyatzis, R. - McKee, A. (2002) The New Leaders. Boston, Harvard Business School Press.

73. Goleman, D. (2004): What makes a leader? Harvard Business Review, 82(1), pp. 82-91. DOI: http://dx.doi.org/10.1111/j.0955-6419.2004.00313.

74. Goldratt, E. M. (1997). The critical chain. The North River Press, Great Barrington.

75. Grundy, T. (1998) Strategic implementation and project management. International Journal of Project Management, 16(1), pp 43-50 DOI: http://dx.doi.org/10.1016/S0263-7863(97)00016-1

76. Görög, M. (1996) Általános projektmenedzsment. Aula Kiadó, Budapest.

77. Görög, M. (2003): A projektvezetés mestersége. Aula kiadó, Budapest.

78. Görög, M. (2007): A projektvezetés mestersége. Aula Kiadó, Budapest.

79. Görög, M. (2008): Projektvezetés. Aula Kiadó, Budapest.

80. Görög, M. (2013): A Strategic Oriented Implementation of Projects. PMI Publications, Newton Square, Pennsylvania.

81. Görög, M. (2013b): A Strategic Oriented Implementation of Projects. PMI Publications, Newton Square, Pennsylvania.

82. Görög, M. - Smith, N. J. (1999): Project Management for Managers. PMI Publications, Newtown Square, Pennsylvania.

83. Grundy, T - Brown, L. (2002) Strategic Project Management. London, Thomson Learning

84. Hall, M. - Holt, R. - Purchase, D. (2003): Project sponsors under new public management: lessons from the frontline. International Journal of Project Management, 21(7), pp. 495-502. DOI: http://dx.doi.org/10.1016/S02637863(02)00054-6

85. Hartman, F. - Ashrafi, R.A. (2002) "Project Management in the Information Systems and Information Technologies Industries", Project Management Journal, 33(3), pp. 5-15. 
86. Hassen, S. M. et al (2011): Future criteria for success of building projects in Malaysia. International Journal of Project Management, 29(5), pp. 514524. DOI: http://dx.doi.org/10.1016/j.ijproman.2010.03.003

87. Ho, Y., Chang, O. - Wang, W. (2008): An empirical study of key success factors for Six Sigma Green Belt projects at an Asian MRO company. Journal of Air Transport Management 14(5), pp. 263-269. DOI: http://dx.doi.org/10.1016/j.jairtraman.2008.05.002

88. Horváth, V. (2013): Knowledge Management in the Project-Oriented Organisations. Conference presentation, 15.11.2013, Hatfield, England.

89. Hwang, B. - Ng., W. J. (2013): Project management knowledge and skills for green construction: Overcoming challenges. International Journal of Project $\begin{array}{llll}\text { Management, } & 31(2), & \text { 272-284. } & \text { DOI: }\end{array}$ http://dx.doi.org/10.1016/j.ijproman.2012.05.004

90. International Project Management Association (2014): The PE Model. [Online], [Letöltve: 2014. július 28-án]. Elérhetö: http://ipma.ch

91. Ivancevich, J.M., Szilagi, A.D., Wallace, M.J., 1977. Organizational Behavior and Performance. Goodyear Publishing Co., Inc., California.

92. Jang, Y. - Lee, J. (1998): Factors influencing the success of management consulting projects. International Journal of Project Management, 16(2), pp. 67-72. DOI: http://dx.doi.org/10.1016/S0263-7863(97)00005-7

93. Jiang, J. J. et al. (1996): Ranking of system implementation success factors. Project Management Journal, 27(1), pp. 50-55.

94. Jha, K.N. - Iyer, K.C., 2007. Commitment, coordination, competence and the iron triangle. International Journal of Project Management, 25(5), 527-540. DOI: http://dx.doi.org/10.1016/j.ijproman.2006.11.009

95. Judgev, K. \& Müller, R. (2005): A Retrospective Look at Our Evolving Understanging of Project Success. Project Managament Journal, 36(4), pp. 19-31. DOI: http://dx.doi.org/10.1109/EMR.2006.261387

96. Kappelman, L. A. - McKeeman, R. - Zhang, L. (2006): Early warning signs of IT project failure: The dominant dozen; Information Systems Management, 23(4), pp. 31-37. DOI: http://dx.doi.org/10.1201/1078.10580530/46352.23.4.20060901/95110.4

97. Kendra, K. - Taplin, L.J. (2004): Project success: a cultural framework. Project Management Journal 35(1), pp. 30-45. 
98. Kindler, J. - Papp, O. (1984): Komplex rendszerek vizsgálata Összemérési módszerek. KJK, Budapest.

99. Kiss, J. - Molnár, B. - Klimkó, G. (1993a): Az informatikai stratégia kialakításának és megvalósításának irányelvei. [Letöltve: 2013. április 24-én]. Elérhető: http://www.itb.hu/ajanlasok/a2

100. Kiss, J. - Molnár, B. - Klimkó, G. (1993b): Bevezetés a PRINCE projektirányítási módszertanba. [Letöltve: 2013. április 27-én]. Elérhető: http://www.itb.hu/ajanlasok/a5

101. Kleim, R. L. (2008) Effective Communications for Project Management. Auerbach Publications, New York.

102. Kuhn, T. (1984): A tudományos forradalmak szerkezete. Gondolat Kiadó, Budapest.

103. Kun, E. (2005): Sydney Operaházának Felavatása [Online], [Letöltve: 2013. április 6-án]. Elérhető: http://www.geographic.hu/

104. Labuschagne, C - Brent, A.C. (2005): Sustainable Project Life Cycle Management: the need to integrate life cycles int he manufacturing sector. International Journal of Project Management, 23(1), pp. 159-168. DOI: http://dx.doi.org/10.1016/j.ijproman.2004.06.003

105. Lee-Kelley, L. - Loong, K. L. (2003) Turner's five-functions of project-based management and situational leadership in IT services projects. International Journal of Project Management, 21(8), pp 583-591 DOI: http://dx.doi.org/10.1016/S0263-7863(02)00100-X

106. Lim, C. S. - Mohamed, M. Z. (1999): Criteria of project success: an exploratory re-examination. International Journal of Project Management, 17(4). DOI: http://dx.doi.org/10.1016/S0263-7863(98)00040-4

107. Lindner, F. - Wald, A. (2011): Success factors of knowledge management in temporary organizations. International Journal of Project $\begin{array}{llll}\text { Management, } & \text { 29(7), } & \text { 877-888. } & \text { DOI: }\end{array}$ http://dx.doi.org/10.1016/j.ijproman.2010.09.003

108. Loo, R. (2002) Working towards best practices in project management: a Canadian study. International Journal of Project Management, 20(2), pp 93-98. DOI: http://dx.doi.org/10.1016/S0263-7863(00)00042-9

109. Mantel Jr, S. J. - Meredith, J. R. - Shafer, S. M. - Sutton, M. M. (2001) Project management in practice. John Wiley \& Sons, New York. 
110. Magyari-Beck, I. (2006): Kulturális marketing és kreatológia. Semmelweis Kiadó, Budapest.

111. Mészáros, T. (2005): A stratégia jövője - a jövő stratégiája. Aula Kiadó, Budapest.

112. Mészáros, T. (2010): Régi és új elemek a stratégiai gondolkodásban. Vezetéstudomány, 41(4), pp. 2-12.

113. Molnár, B. (1997): Projektirányítás módszertana (Prince). [Letöltve: 2013. május 1-jén]. Elérhető: http://www.mtaita.hu/hu/Publikaciok/PRINCEMASTER.pdf

114. Müller, R. - Turner, J. R. (2007): Matching the project manager's leadership style to project type. International Journal of Project Management, 25(1), pp. 21-32. DOI: http://dx.doi.org/10.1016/j.ijproman.2006.04.003

115. Müller, R. - Turner, R. (2010): Leadership competency profiles of successful project managers. International Journal of Project Management, 28(7), pp. 437-448. DOI: http://dx.doi.org/10.1016/j.ijproman.2009.09.003

116. Nauman, S. - Khan, A., M. - Ehsan, N. (2010): Patterns of empowerment and leadership style in project environment. International Journal of Project Management, 28(7), pp. 638-649. DOI: http://dx.doi.org/10.1016/j.ijproman.2009.11.013

117. Ng, S. T. -Tang, Z. (2010): Labour-intensive construction subcontractors: Their critical success factors. International Journal of Project $\begin{array}{llll}\text { Management, } & \text { 28(7), } & \text { pp. } & \text { DOI: }\end{array}$ http://dx.doi.org/10.1016/j.ijproman.2009.11.005

118. Olsen, R. P. (1971) Can project management be defined? Project Management Quarterly, 2(1), pp 12-14

119. Papke-Shields, K. E., Beise, C. - Quan, J. (2010): Do project managers practice what they preach, and does it matter to project success? International Journal of Project Management, 28(7), pp. 650-662. DOI: http://dx.doi.org/10.1016/j.ijproman.2009.11.002

120. Patanakul, P. - Milosevic, D. (2009): The effectiveness in managing a group of multiple projects: Factors of influence and measurement criteria. International Journal of Project Pinto, J. K.(2000): Understanding the role of politics in successful project management. International Journal of Project Management, 18(2), pp. 85-91. DOI: http://dx.doi.org/10.1016/j.ijproman.2008.03.001 
121. Pinto, J. K. (2000) Understanding the role of politics in successful project management. International Journal of Project Management, 18(1), pp. 85-91. DOI: http://dx.doi.org/Understanding the role of politics in successful project management

122. Pinto, J.K. - Kharbanda, O.P. (1996), "How to fail at project management (without really trying)," Business Horizons, 39 (4), 45 - 53. DOI: http://dx.doi.org/10.1016/S0007-6813(96)90051-8

123. Pinto, J.K. - Slevin, D. P. (1987): Critical factors in successful project implementation. IEEE Trans. Eng. Manage. EM 34 (1), pp. 22-27. DOI: http://dx.doi.org/10.1002/9780470172353.ch20

124. Pollack, J. (2012): Transferring knowledge about knowledge management: Implementation of a complex organisational change programme. International Journal of Project Management, 30(8), pp. 887-886. DOI: http://dx.doi.org/10.1016/j.ijproman.2012.04.001

125. Prabhakar, G. P. (2005) Switch leadership in projects - An empirical study reflecting the importance of transformational leadership on project success across twenty-eight nations. Project Management Journal, 36(4), pp 53-60.

126. Project Management Institute (2000): A guide to the Project Management Body of Knowledge. PMI Publications, Newtown Square, Pennsylvania.

127. Project Management Institute (2006): Projektmenedzsment útmutató. Akadémia kiadó, Budapest

128. Project Management Institute (2008): A guide to the Project Management Body of Knowledge. PMI Publications, Newtown Square, Pennsylvania.

129. Radujković, M. - Izetbegović, J. (2000) The human role in project time-cost overrun scenario. in: Proceedings of the SENET Regional Conference on Project Management. Ljubljana, Szlovénia. In: Görög, M. (2007): A projektvezetés mestersége. Aula Kiadó, Budapest.

130. Rawlings, P. E. (1987): Maintenance element of a probabilistic approach to project life cycle costing. International Journal of Project Management, 5(3), pp. 149-154. DOI: http://dx.doi.org/10.1016/0263-7863(87)90019-6

131. Rockart, J. F. (2002): Critical Succes Factors: A 2002 Retrospective. [Letöltve: 2013. március 8-án]. Elérhető: http://web.mit.edu/ 
132. Robbins, S.P. (1997)_ Essentials of Organizational Behaviour. Prentice Hall, Englewood Cliffs, NJ

133. Rozman, R. (2006): Some organizational corporate governance issues in Slovenian enterprises. EBS Review, 21(1), pp. 104-116 DOI: http://dx.doi.org/10.1016/S0263-7863(98)00069-6

134. Savolainen, P. et al (2012): Software development project success and failure from the supplier's perspective: A systematic literature review. International Journal of Project Management, 30(4), pp. 458-469. DOI: http://dx.doi.org/10.1016/j.ijproman.2011.07.002

135. Schmid, B. - Adams, J. (2008) Motivation in Project Management: The Project Manager's Perspective. Project Management Journal, 39(2), pp 60-71. DOI: http://dx.doi.org/10.1002/pmj.20042

136. Shenhar, A. I. (2001). One size does not fit all projects: Exploring classical contingency domains. Management Science, 47[3) pp.394-414. DOI: http://dx.doi.org/10.1287/mnsc.47.3.394.9772

137. Shenhar, A. - Dvir, D. (2007) Project management research - The challenge and opportunity. Project Management Journal, 38(2), pp. 93-99.

138. Simon, H. (1957): Models of Man, Wiley, New York.

139. Simon, H. (1982): Models of Bounded Rationality, MIT Press, Cambridge, MA

140. Spencer, L. M. J. - Spencer, S. M. (1993) Competence at work: models for superior performance. New York, John Wiley \& Sons.

141. Standish Group (2009).: The Standish Group Report - Chaos; [Letöltve: 2013. április 30-án]. Elérhető: http://www.cs.nmt.edu/

142. Stevenson, D. - Starweather, J. A. (2010): PM critical competency index: IT execs prefer soft skills. International Journal of Project Management, 28(7), pp. 663-671. DOI: http://dx.doi.org/10.1016/j.ijproman.2009.11.008

143. Thomas, G. - Fernández, W. (2008): Success in IT projects: A matter of definition? International Journal of Project Management, 26(7), pp. 733-742. DOI: http://dx.doi.org/10.1016/j.ijproman.2008.06.003

144. Thomas, D. - Bendoly, E. (2009) Limits to Effective Leadership Style and Tactics in Critical Incident Interventions. Project Management Journal, 40(2), pp. 70-80. DOI: http://dx.doi.org/10.1002/pmj.20118 
145. Tofallis, C. (2012): An automatic-democratic approach to weight setting for the new human development index. [Online], [Letöltve: 2014. augusztus 25-én]. Elérhetö: https://uhra.herts.ac.uk/

146. Toor, S. - Ogunlana, S. O. (2010): Beyond the 'iron triangle': Stakeholder perception of key performance indicators (KPIs) for large-scale public sector development projects. International Journal of Project Management, 28(3), pp. 228-236. DOI: http://dx.doi.org/10.1016/j.ijproman.2009.05.005

147. Turner, J. R. (1999a) Editorial - Project management: a profession based on knowledge or faith? International Journal of Project Management, 17(6), pp 329-330. DOI: http://dx.doi.org/10.1016/S0263-7863(99)00020-4

148. Turner, J. R. (1999b). The Handbook of Project-based Management: Improving the Processes for Achieving Strategic Objectives. McGraw-Hill, London.

149. Turner, J. R. (2004): Five necessary conditions for project succes. International Journal of Project Management, 22(5), pp. 349-350. DOI: http://dx.doi.org/10.1016/j.ijproman.2004.02.001

150. Turner, J. R. (2006): Editorial - Towards a theory of project management: The nature of the project. International Journal of Project Management, 24 (1), pp 1-3 DOI: http://dx.doi.org/10.1016/j.ijproman.2005.11.007

151. Turner, J. R. (2009) Handbook of project based management: Leading strategic changes in organizations (3rd ed.). McGraw-Hill Professional, New York.

152. Turner, J. R. - Müller, R. (2003) On the nature of the project as a temporary organization. International Journal of Project Management, 21(1), pp. 1-8. DOI: http://dx.doi.org/10.1016/S0263-7863(02)00020-0

153. Turner, J. R. - Müller, R. (2005) The project manager's leadership style as a success factor on projects: A literature review. Project Management Journal, 36(2), pp. 49-61.

154. Umble, E. J., Haft, R. R. - Umble, M. M. (2003): Enterprise resource planning: Implementation procedures and critical success factors. European Journal of Operational Research, 146(2), pp. 241-257. DOI: http://dx.doi.org/10.1016/S03772217(02)00547-7

155. Verzuh, E. (2008): The Fast Forward MBA in Project Management. John Wiley \& Sons, Inc., Hoboken, New Jersey. 
156. Wateridge, J. (1997): How can IS/IT projects be measured for success? International Journal of Project Management, 16(1), pp. 55-63. DOI: http://dx.doi.org/10.1016/S0263-7863(97)00022-7

157. Worthen, B. (2008): Nestlé's Enterprise Resource Planning (ERP) Odyssey. [Letöltve: 2013. március 24-e]. Elérhető: http://www.cio.com

158. Yang, L. , Huang, C. - Wu, K. (2011): The association among project manager's leadership style, teamwork and project success. International Journal of $\begin{array}{llll}\text { Project } & \text { Management, } & \text { 29(3), } 258-267 . & \text { DOI: }\end{array}$ http://dx.doi.org/10.1016/j.ijproman.2010.03.006

159. Yeo, K. T. (2002): Critical failure factors in information system projects. Internation Journal of Project Management, 20(3), pp. 241-246. DOI: http://dx.doi.org/10.1109/ICSSSM.2005.1500108

160. Yu, A. G. et al (2005) Developing a value-centred proposal for assessing project success. International Journal of Project Management, 23(6), pp. 428-436. DOI: http://dx.doi.org/10.1016/j.ijproman.2005.01.008

161. Yu, J. and Kwon, H (2011): Critical success factors for urban regeneration projects in Korea. International Journal of Project Management, 29(7), pp. 889-899. DOI: http://dx.doi.org/10.1016/j.ijproman.2010.09.001

162. van den Ende, L. - van Marrewijk, A. (2014): The ritualization of transitions in the project life cycle: A study of transition rituals in construction projects. International Journal of Project Management, 32(7), pp. 1134-1145. DOI: http://dx.doi.org/10.1016/j.ijproman.2014.02.007

163. Wang, E. - Chou, H-W - Jiang, J. (2005): The impacts of charismatic leadership style on team cohesiveness and overall performance during ERP implementation. International Journal of Project Management, 23(3), pp. 173-180. DOI: http://dx.doi.org/10.1016/j.ijproman.2004.09.003

164. Wateridge, J. (1997): How can IS/IT projects be measured for success? International Journal of Project Management, 16(1), pp. 55-63. DOI: http://dx.doi.org/10.1016/S0263-7863(97)00022-7

165. Westerfeld, E. (2003): The Project Excellence Model $\AA$ : linking success criteria and critical success factors. International Journal of Project Management, 21(6), pp. 411-418. DOI: http://dx.doi.org/10.1016/S02637863(02)00112-6 
166. Winterton, J. - Delamare - Le Deist, F. - Stringfellow, E. (2006): Typology of knowledge, skills and competences:clarification of the concept and prototype. European Centre for the Development of Vocational Training. Thessaloniki, Greece.

167. World Bank (2005): Little Data Book. The World Bank Development Data Book, Washington DC.

168. Wysocki, R. K. (2013): Effective Project Management: Traditional, Agile, Extreme, 7th Edition. [Online]. ISBN szám: 1118729161

169. Zimmerer, T. W. - Yasin, M. M. (1998) A leadership profile of American project managers. Project Management Journal, 29(1), pp 31-38. 


\section{Publikációk jegyzéke}

\section{Magyar nyelvü publikációk jegyzéke a témában:}

Könyvrészlet:

Blaskovics, B. - Futó, I. - Klimkó, G. (2014): IKT-projektmenedzsment a közigazgatásban. In: Nemeslaki András: E-közszolgálatfejlesztés - Elméleti alapok és tudományos kutatási módszerek. Nemzeti Közszolgálati Egyetem, Budapest.

Folyóirat:

Blaskovics, B. (2012): A projektvezető vezetési stílusának hatása a projektsikerre egy hazai vállalat példája alapján. Vezetéstudomány, elfogadott pályázati anyag.

Konferenciakötetben megjelenő előadás:

Blaskovics, B. (2010): Kritikus sikertényezők kölcsönhatása és összefüggésük a sikerkritériumokkal. HTE Konferencia, 08.04.2010..

\section{Idegen nyelvű publikációk jegyzéke a témában:}

\section{Folyóirat:}

Blaskovics, B. (2014): Impact of leadership styles on project success - The case of a multinational company. Dynamic Relationship Management, elfogadott pályázati anyag.

Blaskovics, B. (2014): The impact of project manager on project success - The case of ICT sector. Society \& Economy, elfogadott pályázati anyag.

\section{Konferenciakötetben megjelenő kiadvány:}

Blaskovics, B. (2010): Interrelationships between CFs, SC and PM maturity - A research initiation. PMUni Conference, 17.11.2010.

Blaskovics, B. (2014): Aspects of projects success - The case of a multinational company. PMUni Conference, 12.05.2014

Konferenciakötetben nem megjelenő előadás:

Blaskovics, B. (2013): Impact of attitude on project success. University of Hertfordshire, 15.11.2013. 


\section{Mühelytanulmány:}

Blaskovics, B. - Görög, M. (2011): Evaluation of project success and efficiency of project implementation - Success criteria and success factors. Mühelytanulmány. Ericsson Project Management Lab.

Blaskovics, B. - Boda, E. - Görög, M. - Tóth, T. (2012): Evaluation of project management competencies, their impact on project success and mapping the knowledge of the company. Mühelytanulmány. Ericsson Project Management Lab. 